\title{
Groundwater Impact Assessment Report for the 1325-N Liquid Waste Disposal Facility
}

Prepared for the U.S. Department of Energy Office of Environmental Restoration and Waste Management

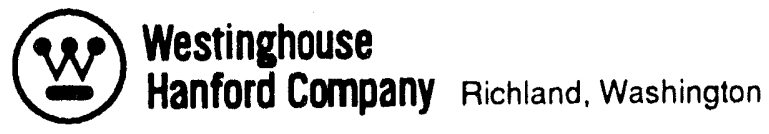

Hantord Operations and Engineering Contractor for the

U.S. Department of Energy under Contract DE-AC06-87RL10930 


\section{TRADEMARK DISCLAIMEA}

Reference herein to any specific commercial product, process, or service by trade name, trademark, manufacturer, or otherwise, does not necessarily constitute or imply its endorsement, recommendation, or favoring by the United

States Government or any agency thereot or its contractors or subcontractors.

This report has been reproduced from the best available copy. Available in paper copy and microfiche.

Available to the U.S. Department of Energy

and its contractors from

Office of Scientific and Technical Information

P.O. Box 62

Oak Ridge, TN 37831

(615) 576.8401

Available to the public from the U.S. Department of Commerce

National Technical Information Service

5285 Port Royal Road

Springfield, VA 22161

(703) $487-4650$

Printed in the United States of America

DISCLM-5.CHP (8-91) 


\section{Groundwater Impact Assessment Report for the 1325-N Liquid Waste Disposal Facility}

D. J. Alexander

V. G. Johnson

Date Published

September 1993

Prepared for the U.S. Department of Energy Office of Environmental Restoration and Waste Management

\footnotetext{
(28) Westinghouse

P.O. Box 1970

Hantord Company Richland, Washington 99352

Hanford Operations and Engineering Contractor for the

U.S. Department of Energy under Contract DE-AC06-87RL10930
} 


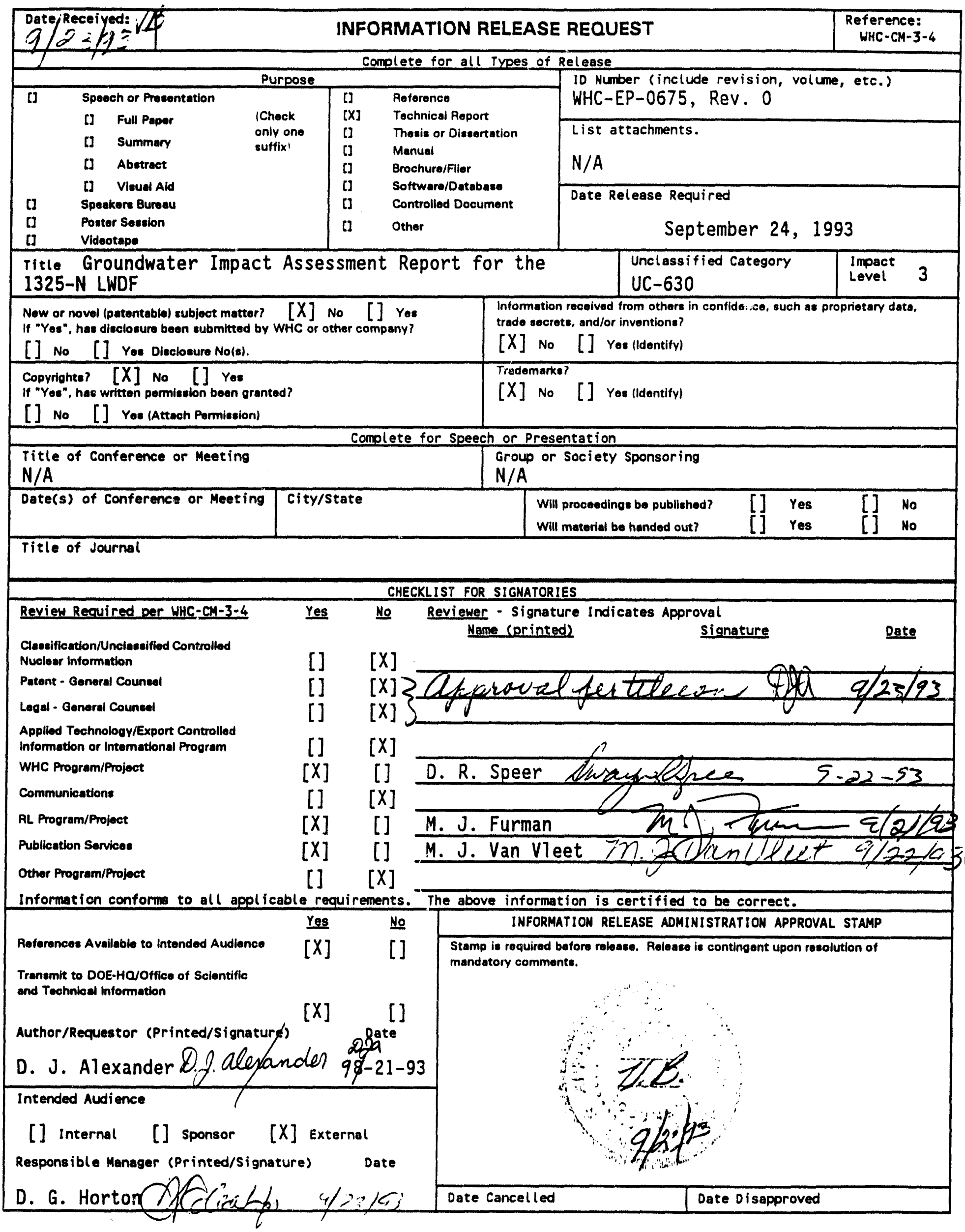


Document Title: Groundwater Impact Assessment Report for the 1325-N Liquid Waste Disposal Facility

Prepared by:

$\frac{\text { Q. Q. Alejandes }}{\text { D. J. ATexander }}$

Geosciences Function

Environmental Division

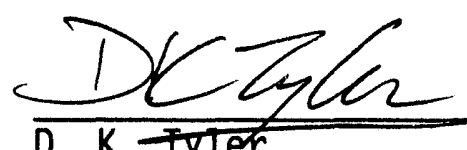

D. K. Tyer

Geosciences Function

Environmental Division

Technical

Review by:

Approved by:

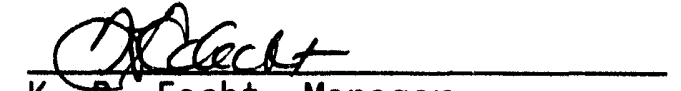

K. R. Fecht, Manager

Geosciences Function

Environmental Division

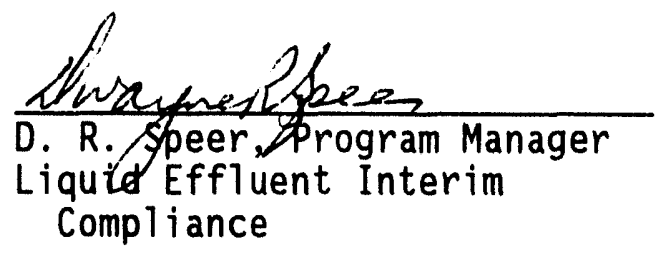

$\frac{9 \cdot 21-93}{\text { Date }}$

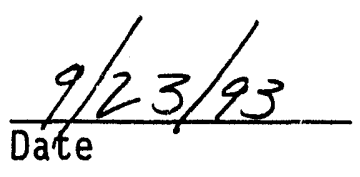

$\frac{9 / 23 / 93}{\text { Date }}$

$\frac{9.23-93}{\text { Date }}$ 
WHC-EP-0675

This page intentionally left blank. 


\section{WHC-EP-0675}

\section{EXECUTIVE SUMMARY}

The 105-N and 109-N Facilities discharged effluent to the 1325-N Liquid Waste Disposal Facility (1325-N LWDF) located east of the 100-N Area perimeter fence. This report satisfies one of the requirements of the Hanford Federal Facility Agreement and Consent Order (Tri-Party Agreement) Milestone M-17-00B as agreed by the U.S. Department of Energy, the Washington State Department of Ecology, and the U.S. Environmental Protection Agency. ${ }^{1}$ Tri-Party Agreement Milestone M-17-OOB includes a requirement to assess impacts to groundwater from disposal of the 105-N Reactor and 109-N Heat Exchanger Buildings effluent to the 1325-N I.WDF. In addition, the 1325-N LWDF is a Resource Conservation and Recovery Act of $1976^{2}$ treatment, storage, and disposal facility covered by the Closure/Post-Closure Plan for the 1301-N and 1325-N Liquid Waste Disposal Facilities. ${ }^{3}$

There is groundwater contamination, primarily strontium-90, tritium, and sulfate, in the unconfined aquifer beneath the 100-N Area. The contaminant plumes are a result of past-practice reactor and disposal operations in the

${ }^{1}$ Ecology, EPA, and DOE, 1991, Hanford Federal Facility Agreement and Consent Order, Second amendment, 2 vols, 89-10, Rev. 2, Washington State Department of Ecology, U.S. Environmental Protection Agency, and U.S. Department of Energy, Olympia, Washington.

${ }^{2}$ Resource Conservation and Recovery Act of 1976, 42 USC 6901, et seq.

${ }^{3}$ Diediker, L. A., and J. A. Hall, 1987, Closure/Post-Closure Plan for the 1301-N and 1325-N Liquid Waste Disposal Facilities, UNI-3533, UNC Nuclear Industries, Inc., Richland, Washington. 
100-N Area currently being investigated as part of the 100-NR-1 and 100-NR-2 Operable Units. ${ }^{4,5}$

One-dimensional or unit-gradient flow and transport calculations suggest that strontium-90 reached the water table during the operational period of use for the 1325-N LWDF. Continuing migration of strontium-90 into the aquifer may be occurring due to natural recharge and water table fluctuations. The estimated magnitude of additional contaminant input to the aquifer caused by hypothetical slug releases of spent emergency water to the crib is about the same order of magnitude as the annual contaminant input to the aquifer caused by natural recharge. The localized concentrations caused by both types of input exceed the Washington State Water Quality Standard of $8 \mathrm{pCi} / \mathrm{L}$ and are potentially significant. Thus some mitigating measures for controlling the natural infiltration around the crib (e.g., restoration of natural vegetation around the crib or installation of an interim infiltration barrier) should be investigated as part of ongoing remediation efforts. Furthermore, emergency water should not be discharged to the crib.

"DOE-RL, 1991a, RCRA Facility Investigation/Corrective Measures Study Work Plan for the 100-NR-1 Operable Unit, Hanford Site, Richland, Washington, DOE/RL-91-46, U.S. Department of Energy, Richland Operations Office, Richland, Washington.

${ }^{5} \mathrm{DOE}-\mathrm{RL}, 1991 \mathrm{~b}$, RCRA Facility Investigation/Corrective Measures Study Work Plan for the 100-NR-2 Operable Unit, Hanford Site, Richland, Washington, $\mathrm{DOE} / \mathrm{RL}-90-22$, U.S. Department of Energy, Richland Operations Office, Richl and, Washington. 
WHC-EP-0675

\section{CONTENTS}

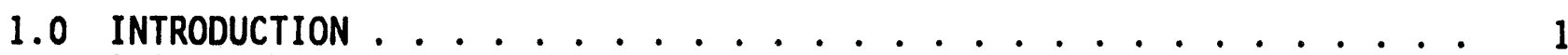

1.1 BACKGROUND ......................... . . . 1

1.2 METHODOLOGY . . . . . . . . . . . . . . . . . . . 1

$2.0100-N$ AREA FACILITIES DESCRIPTION ............... 5

2.1 LOCATION ..................... 5

2.2 HISTORY . . . . . . . . . . . . . . 5

2.3 FACILITIES $\ldots \ldots \ldots 5$

$2.3 .11325-\mathrm{N}$ LWDF ................... 5

$2.3 .21301-N$ LWDF ............... . . . . 10

2.3.3 1324-N/NA Surface Impoundment/Percolation Pond..... 10

2.3 .4 105-N Reactor .................. 11

$2.3 .5109-\mathrm{N}$ Heat Exchanger . . . . . . . . . . . . 11

$3.0 \quad 1325-N$ LWDF EFFLUENT CHARACTERISTICS . . . . . . . . . . . . 13

3.1 SOURCES . . . . . . . . . . . . . . 13

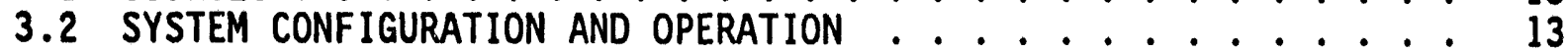

3.3 DISCHARGE VOLUME AND FLOW REGIME ............. 22

3.4 EFFLUENT CONSTITUENTS . . . . . . . . . . . . . . . . . 22

3.4.1 Quantities................. 22

3.4 .2 Loading Rates . . . . . . . . . . . . . . 23

3.4.3 Operational Factors .............. 28

3.5 CONSTITUENTS OF INTEREST AND KEY PARAMETERS $\ldots \ldots \ldots$

4.0 CONCEPTUAL MODEL OF HYDROLOGIC RESPONSE AND CONTAMINANT MIGRATION - 29

4.1 HYDROGEOLOGIC FRAMEWORK ............... 29

4.1.1 Regional and Hanford Site Geology ......... 29

4.1.2 100-N Area Geology . . . . . . . . . . . . 35

4.1.3 Regional and Hanford Site Hydrology ........ 43

4.1.4 100-N Area Hydrology . . . . . . . . . . . . . . 49

4.2 HYDROLOGIC RESPONSES TO EFFLUENT DISPOSAL . . . . . . . . . . 58

4.3 GROUNDWATER QUALITY . . . . . 58

4.4 SOIL COLUMN AND AQUIFER SEDIMENT CHEMICAL FACTORS . . . . 83

4.4.1 Soil Factors . . . . . . . . . . . . 83

4.4.2 Aquifer Sediment Factors . . . 83

4.5 SUMMARY OF CONCEPTUAL MODEL OF MOISTURE MOVEMENT AND

CONTAMINANT TRANSPORT . . . . . . . . . . . . 85

5.0 IMPACT ASSESSMENT $\ldots \ldots \ldots 7$

5.1 HYDRAULIC CONSIDERATIONS ................ . . . 87

5.1.1 Slug Discharge Volume ............. 87

5.1.2 Moisture Status of Soil Column . . . . . . . . . 87

5.1.3 Response to Multiple Releases . . . . . . . . . 87

5.2 CONTAMINANT IMPACTS . . . . . . . . .... 88

5.2.1 One-Dimensional Flow and Transport Analysis

(Analytical Methods) ............ 88

5.2.2 Results of Analytical Solution for Operational Period: 89

5.2.3 Soil Column Pore Fluid Strontium-90 Concentrations ... 92

5.2.4 Mitigating Factors and Alternative Assumptions ..... 97 


\section{CONTENTS (cont.)}

5.3 EVALUATION OF MONITORING NETWORK ADEQUACY ........... . . 98

5.3.1 Groundwater Monitoring Well Placement . . . . . . . 99

5.3.2 Reporting of Monitoring Data ............ 99

6.0 SUMMARY AND CONCLUSIONS .................. 103

7.0 REFERENCES . . . . . . . . . . . . . . . . 105 


\section{LIST OF FIGURES}

1 Location of the 100-N Area on the Hanford Site . . . . . . . . 6

2 Location of Major 100-N Area Facilities . . . . . . . . . . 7

3 Plan View of the 1325-N Liquid Waste Disposal Facility . . . . . . . 8

4 Plan View of the Crib Section of the 1325-N Liquid Waste

Disposal Facility....................... 9

5 Layout of the 100-N Area . . . . . . . . . . . . . . . 17

6 Route of $N$ Reactor Effluent to the 1325-N Liquid Waste Disposal

Facility via the 91.4-cm- (36-in.-) Diameter Low-Pressure

Flush Line .................... 18

7 Schematic of $N$ Reactor Effluent Discharged to the 1325-N Liquid

Waste Disposal Facility ................ 19

8 Effluent Discharge Routes from the 105-N Reactor Building and Adjacent Facilities ................. 20

9 Effluent Discharge Routes to the 1314-N Liquid Waste Railcar Loadout Station During Various Decontamination Activities . . . . . 21

10 Generalized Stratigraphy of the Pasco Basin and Surrounding Area . . 30

11 Generalized Stratigraphy of the Suprabasalt Sediments in the Pasco Basin .................... 32

12 Generalized Stratigraphy of the Miocene-Pliocene Ringold Formation in the Pasco Basin ................. 33

13 Locations of Washington Public Power Supply System Boreholes Near the 100-N Area . . . . . . . . . . . . . . . 36

14 Generalized Stratigraphic Column for the 100-N Area . . . . . . . . 37

15 Line of Cross Sections Drawn West-East and North-South Through the 100-N and Surrounding Area. ............ 38

16 West-East Cross Section Through the 100-N and Surrounding Area . . 39

17 North-South Cross Section Through the 100-N and Surrounding Area. . . 40

18 Geologic Cross Section through the 100 Areas ........... 42

19 Hydrologic Basins Designated for the Washington State Portion of the Columbia Plateau ................. 44

20 Location of Major Liquid Effluent Disposal Sites on the Hanford Site 


\section{LIST OF FIGURES (cont.)}

21 Hindcast Water Table Map of the Hanford Site, January 1944 . . . . . 50

22 Hanford Site Water Table Map, June 1989 . . . . . . . . . . . 51

23 Conceptual Drawing of Hydrogeologic Units in the 100-N Area . . . . 53

24 Groundwater Monitoring Wells In and Near the 1325-N Liquid Waste Disposal Facility..................... 54

25 100-N Area Sewage Lagoon . . . . . . . . . . . . . . . 55

26 Location Map Showing 1991 Shoreline Sampling Locations . . . . . . 57

27 Water Table in the 100-N Area and Vicinity, June 1988 . . . . . . . 59

28 Water Table in the 100-N Area and Vicinity, July 1989 . . . . . . . 60

29 Water Table in the 100-N Area and Vicinity, January 1990 . . . . . 61

30 Water Table in the 100-N Area and Vicinity, January 1993 . . . . . 62

31 Conceptual Drawing of Groundwater Flow in the Uppermost Aquifer at the 100-N Area.................... 63

32 Distribution of Specific Conductance in Groundwater in the 100-N Area . . . . . . . . . . . . . . . . . . 68

33 Distribution of Sodium in Groundwater in the 100-N Area . . . . . . 70

34 Distribution of Chloride in Groundwater in the 100-N Area. . . . . 72

35 Distribution of Nitrate in Groundwater in the 100-N Area . . . . . 73

36 Distribution of Sulfate in Groundwater in the 100-N Area . . . . 75

37 Distribution of Strontium-90 in Groundwater in the 100-N Area . . . 82

38 Distribution of Tritium in Groundwater in the 100-N Area . . . . . . 84

39 Illustrated Conceptual Model for the 1325-N LWDF . . . . . . . . . . 86

40 Lithology of Well 199-N-70 Near the 1325-N Crib . . . . . . . . . 90

41 Hydraulic Conductivity Versus Moisture Content . . . . . . . . . . 91 


\section{LIST OF TABLES}

1 Past and Present Effluent Stream Sources and Amounts Discharged to the 1325-N Liquid Waste Disposal Facility . . . . . . . . . . . . . 14

2 Facilities that Drain to the 1325-N Liquid Waste Disposal Facility . 16

3 Radionuclides and Chemical Loading, N Reactor Effluent . . . . . 24

4 1325-N Liquid Waste Disposal Facility Analysis . . . . . . . . . 25

5 Elevation of Geologic Units at 100-N Area Resource Conservation and Recovery Act of 1976 Sites . . . . . . . . . . . . . . . . 43

6 Hydraulic Parameters for Various Areas at the Hanford Site . . . . 47

7 Summary of Provisional Hanford Site Groundwater Background Values . . 65

8 Antimony-125 Limit of Detection/Limit of Quantification Calculated from Field Blanks ............... 78

9 Cobalt-60 Limit of Detection/Limit of Quantification Calculated from Field Blanks ................. 79

10 Ruthenium-106 Limit of Detection/Limit of Quantification Calculated from Field Blanks .............. 80

11 Cesium-137 Limit of Detection/Limit of Quantification Calculated from Field Blanks.................. 81

12 Effluent Stream Sampling Data . . . . . . . . . . . . 93

13 Initial Analytical Solution Results for the 1325-N LWDF . . . . . . 95

14 Wells Used to Monitor Groundwater Chemistry and Water Levels for the 1301-N Liquid Waste Disposal Facility. . . . . . . . . 100

15 Wells Used to Monitor Groundwater Chemistry and Water Levels for the 1324-N/NA Liquid Waste Disposal Facility .......... 101

16 Wells Used to Monitor Groundwater Chemistry and Water Levels for the 1325-N Liquid Waste Disposal Facility. . . . . . . . . . 102 


\section{LIST OF TERMS}

$\begin{array}{ll}\text { BTV } & \text { background threshold value } \\ \text { CERCLA } & \text { Comprehensive Environmental Response, Compensation, and } \\ \text { Liability Act of } 1980 \\ \text { CRBG } & \text { Columbia River Basalt Group } \\ \text { CRQL } & \text { contractually required quantification limit } \\ \text { DOE } & \text { U.S. Department of Energy } \\ \text { ECology } & \text { Washington State Department of Ecology } \\ \text { EPA } & \text { U.S. Environmental Protection Agency } \\ \text { FL(LP) } & \text { low-pressure flush line } \\ \text { LWDF } & \text { Liquid Waste Disposal Facility } \\ \text { Ppb } & \text { parts per billion } \\ \text { ppm } & \text { parts per million } \\ \text { RCRA } & \text { Resource Conservation and Recovery Act of } 1976 \\ \text { RDR } & \text { radioactive drain } \\ \text { RL } & \text { DOE, Richland Operations Office } \\ \text { 1324-N } & \text { l324-N Surface Impoundment } \\ \text { Tri-Party } & \text { Hanford Federal Facility Agreement and Consent Order } \\ \text { Agreement } & \text { Washington Administrative Code } \\ \text { WAC } & \text { Westinghouse Hanford Company } \\ \text { WHC } & \text { Washington State Water Quality Standards } \\ \text { WWQS } & \end{array}$




\section{GROUNDWATER IMPACT ASSESSMENT REPORT FOR THE 1325-N LIQUID WASTE DISPOSAL FACILITY}

\subsection{INTRODUCTION}

Groundwater impact assessments are required for a number of liquid effluent receiving sites in accordance with the Hanford Federal Facility Agreement and Consent Order (Tri-Party Agreement) Milestones M-17-00A and $M-17-00 B$, as agreed by the U.S. Department of Energy (DOE), the Washington State Department of Ecology (Ecology), and the U.S. Environmental Protection Agency (EPA) (Ecology et a1. 1991). This report assesses the impacts to groundwater from the disposal of past and present effluent from various 100-N Area facilities to the 1325-N Liquid Waste Disposal Facility (1325-N LWDF).

\subsection{BACKGROUND}

In response to public comments on the original Tri-Party Agreement and at the request of the signatories on the Tri-Party Agreement, the DOE, Richland Operations office (RL) conducted a study to assess the impact of 1 iquid effluents discharged ta the ground at the Hanford Site (WHC 1990a, 1990b). The EPA and Ecology expressed several concerns regarding uncertainties in the evaluations made by RL. Foremost among these concerns were the lack of sitespecific data, the need to consider interactions with adjacent liquid discharge facilities, and the need for more rigorous models of contaminant transport. As a result of these concerns, the RL, Ecology, and EPA (the three parties) created a series of Tri-Party Agreement milestones, including $M-17-00 A, M-17-00 B, M-17-13$, and $M-17-13 A$, which pertain to groundwater impact assessments.

Tri-Party Agreement Milestones $\mathrm{M}-17-00 \mathrm{~A}$ and $\mathrm{M}-17-00 \mathrm{~B}$ require impact assessments for Phase I and II waste streams. Phase I and II waste streams are defined in Stordeur and F1yckt (1988). The 1325-N LWDF was defined as a Phase I waste stream. Tri-Party Agreement Milestone M-17-13 required the development of a methodology for assessing the impact of liquid effluent discharge on groundwater, which resulted in the document $A$ Methodology for Assessing Impacts to Groundwater fron. Disposal of Liquid Effluent to the Soil at the Hanford Site (Tyler 1991). Tirirty days after regulatory approval of the methodology document, as required by Tri-Party Agreement Milestone M-17-13A, a schedule for performing assessments at 13 receiving sites was completed. A draft Resource Conservation and Recovery Act of 1976 (RCRA) closure/post-closure plan has been prepared for the 1325-N LWDF (Diediker and Hal1 1987) and is scheduled to be resubmitted in June 1994 (Tri-Party Agreement Milestone M-20-31). Initial characterization of this site is presently in progress.

\subsection{METHODOLOGY}

The methodology document by Tyler (1991) was followed in preparing the groundwater impact assessment for the 1325-N LWDF. Included in that document is the categorization of each of the 13 receiving sites into 1 of 3 levels, 
based on the amount of effort needed to perform the assessment. A level 1 receiving site groundwater impact assessment relies on available information. . A groundwater impact assessment of a level 2 receiving site may require nonintrusive field work to verify the extent of existing contamination. A level 3 site may require intrusive field work. If it is discovered that existing information is inadequate through the course of performing a level 1 impact assessment, the assessment may be raised to a level 2 or 3 .

The methodology document outlines several tasks to be conducted as part of the groundwater impact assessment for level 1 receiving sites:

- Prepare and present a plan describing how the groundwater impact assessment will be conducted

- Characterize the liquid effluent stream

- Evaluate the site-specific hydrogeology

- Develop a site conceptual nodel

- Assess the hydrologic impact of the liquid effluent stream

- Assess the contaminant impact of the liquid effluent stream

- Evaluate the adequacy of the existing monitoring well network

- Prepare a written report of the results.

The tasks required for level 2 and 3 receiving sites include those outlined above (with minor differences) and include field work-related activities as follows:

- Organize and plan facility-specific assessment (same as level 1 tasks)

- Characterize effluent using existing data (same as level 1 tasks)

- Develop a preliminary site conceptual model--aids in identification of information necessary to refine the conceptual model and support assessment techniques that may have more rigorous data requirements

- Identify additional information needs and plan data collection--may include collection of field data and laboratory analyses (water chemistry sampling, shallow soil samples, remote sensing, geophysical surveys, water level measurements, and physical and chemical analyses of archived soil samples)

- Level 3 data collection may also include borehole drilling and sampling, monitoring well construction (RCRA standard), aquifer testing, and more extensive data collection for activities listed in the previous bullet

- Collect field data

- Analyze and interpret data to refine conceptual model 
- Assess groundwater impacts and identify additional information needs

- Prepare a written report of the results.

In the methodology report (Tyler 1991), the 1325-N LWDF was categorized as a level 1 receiving site because of the substantial decreases in allowable discharge in accordance with the Tri-Party Agreement floid restrictions (Tyler 1991). An administrative policy to cease discharges, except for emergency fire flow, was implemented in April 1991. New monitoring wells were installed at this site to characterize the groundwater in support of RCRA closure/post-closure activities (Hartman 1992). In addition, this site is part of the 100-NR-2 Groundwater Operable Unit and the 100-NR-1 Source Operable Unit, which are controlled by the RCRA Facility Investigation/ Corrective Measures Study Work P1ans (DOE-RL 1991a, 1991b). This impact assessment incorporated data collected under the RCRA Facility Investigation/ Corrective Measires Study Work Plans.

Several key assumptions inherent to all groundwater impact assessments are explained in the methodology document (Tyler 1991) and warrant summarizing here. For this impact assessment, the following assumptions are relevant.

- The expected level of impact from the use of the receiving site determines how well the chemistry, geology, and hydrology need to be understood.

- Modeling sophistication is tailored to available information and the expected level of impact to the receiving site.

- New site-specific geologic, hydrologic, and groundwater data obtained through drilling require 1.5 to 2 years to acquire.

- Data collection and modeling activities are integrated with other Tri-Party Agreement milestones.

- Existing data are treated as fully validated. 
WHC-EP-0675

\section{$2.0 \quad 100-N$ AREA FACILITIES DESCRIPTION}

\subsection{LOCATION}

The Hanford Site is a $1,450-\mathrm{km}^{2}\left(\mathrm{j} 60-\mathrm{mi}^{2}\right)$ tract of land located in Benton, Franklin, and Grant Counties in the south-central portion of Washington State. The 100-N Area is located along the south shore of the Columbia River in the northern part of the Hanford Site, approximately $74 \mathrm{~km}$ (46 mi) north of the city of Richland (Figure 1). The 1325-N LWDF is located approximately $18 \mathrm{~m}$ (60 ft) above and $732 \mathrm{~m}(2,400 \mathrm{ft}$ ) east of the Columbia River and outside the 100-N Area perimeter fence (Figure 2).

\subsection{HISTORY}

In 1943 the Hanford Site was chosen as a location for the Manhattan Project to produce plutonium for use in nuclear weapons. The 100-N Area at Hanford was used from 1963 to 1987 for a dual-purpose, plutonium production and steam generation reactor and related operational support facilities (Diediker and Hall 1987). In November 1989, the reactor was put into dry layup status. During operations, chemical and radioactive wastes were released into the area soil, air, and groundwater. The 1325-N LWDF was constructed in 1983 to replace the 1301-N Liquid Waste Disposal Facility (1301-N LWDF). The two facilities operated simultaneously from 1983 to 1985. The 1301-N LWDF was retired from use in 1985 and the 1325-N LWDF continued operation until April 1991, when active discharges to the facility ceased. Effluent discharge to the piping system has been controlled by administrative means.

\subsection{FACILITIES}

\subsubsection{5-N LWDF}

The 1325-N LWDF is a crib and trench facility (Figure 3 ). The crib is 73 by 76 by $5 \mathrm{~m}$ ( 240 by 250 by $15 \mathrm{ft}$ ) and consists of a drain field pipe system covered with precast, prestressed concrete panels (Figure 4). The cover is $3 \mathrm{~m}$ (10 ft) below ground surface and $1.5 \mathrm{~m}(5 \mathrm{ft}$ ) above the percolation surface (see Figure 3, inset). The trench is 914 by 17 by $2 \mathrm{~m}$ $(3,000$ by 55 by $7 \mathrm{ft})$ and ties into the crib at its northern and eastern corners (effluent from each corner combines in a common weir box) (see Figures 3 and 4 ). The 1325-N LWDF began operation in 1983 as a crib that was constructed to replace the 1301-N LWDF. In 1985, the extension trench was added to the facility to increase its operational capacity (DOE-RL 1991a) and the 1301-N LWDF was shut down. The facility received effluent until April 1991, when all discharges were stopped through the use of administrative controls. 
Figure 1. Location of the 100-N Area on the Hanford Site.

\section{The Hanford Site}

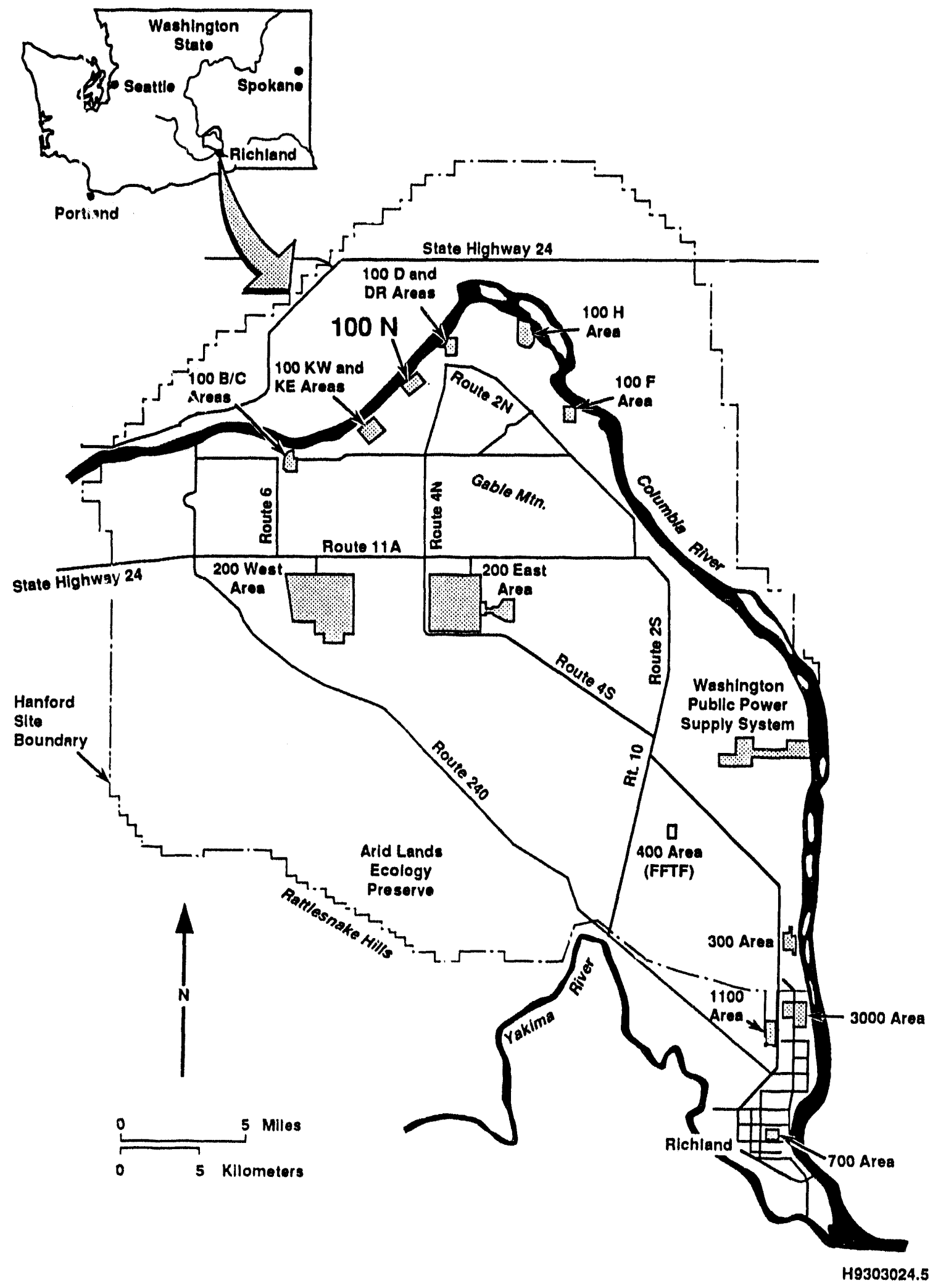




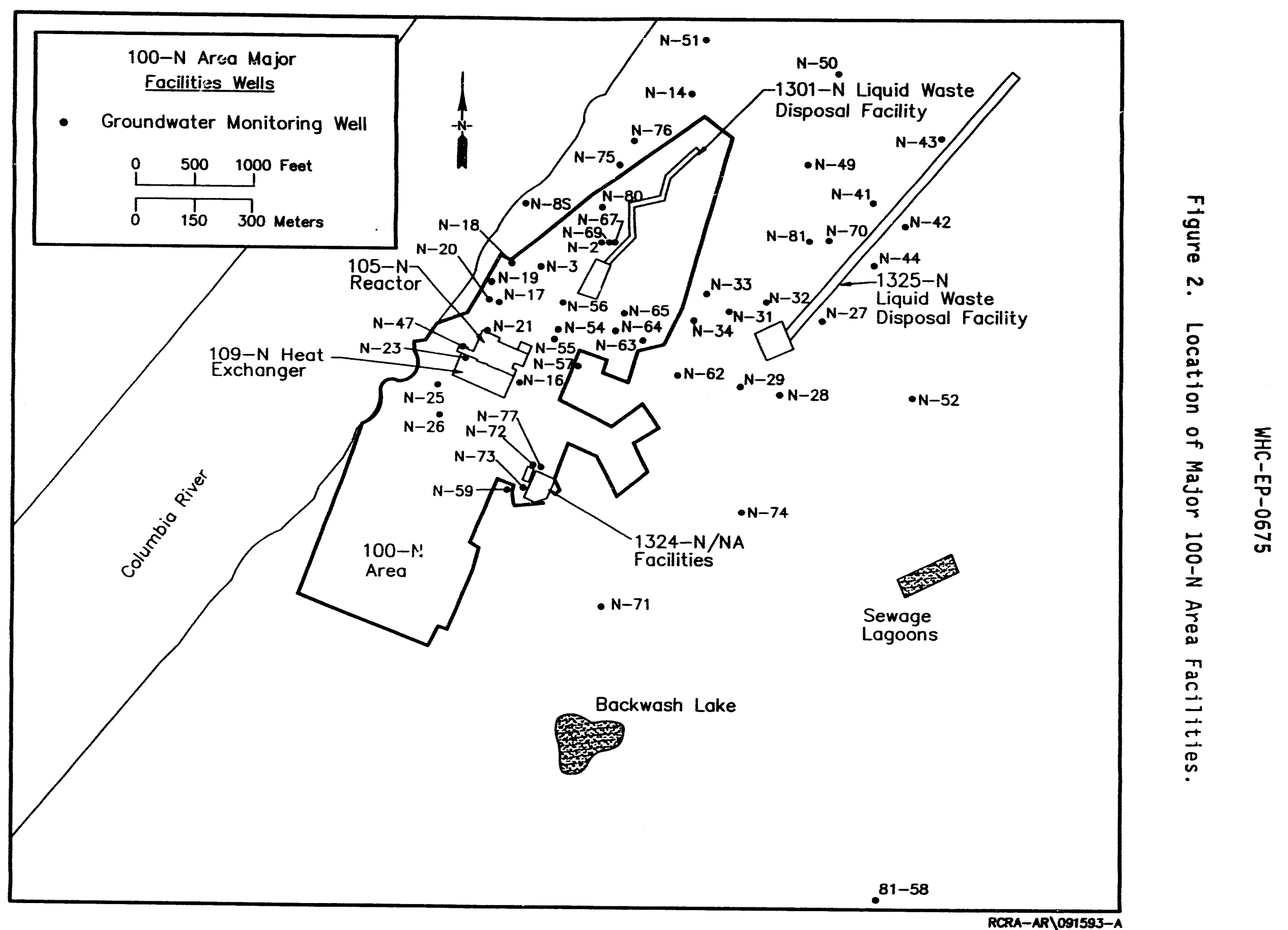




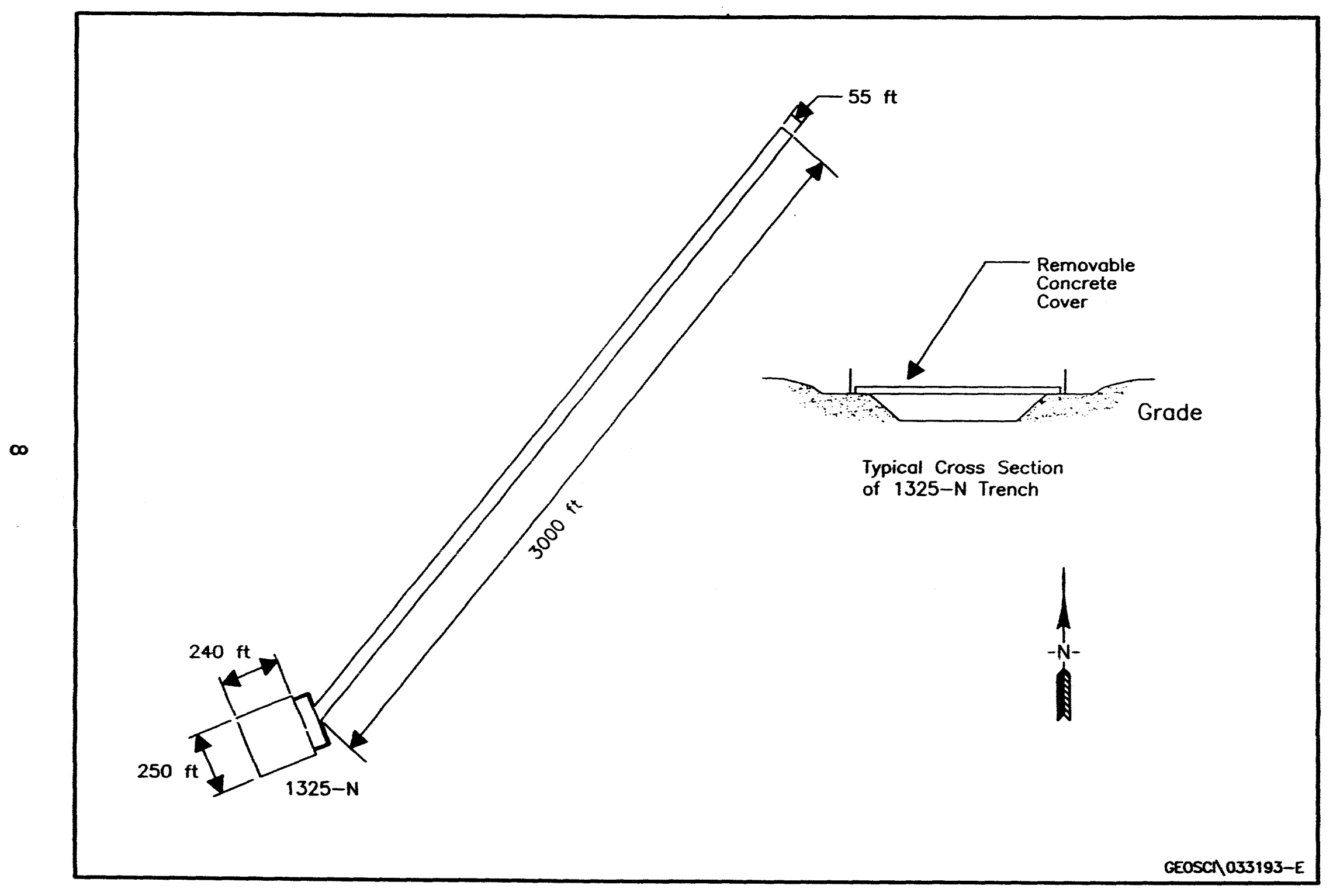

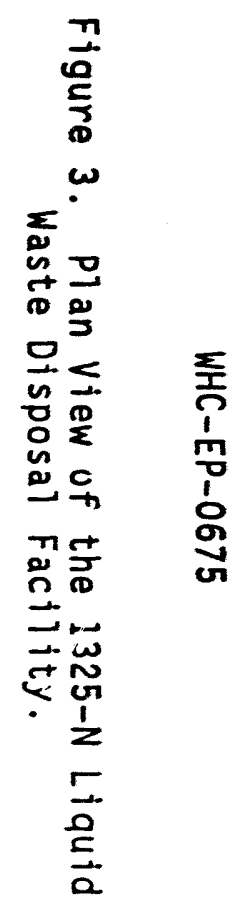




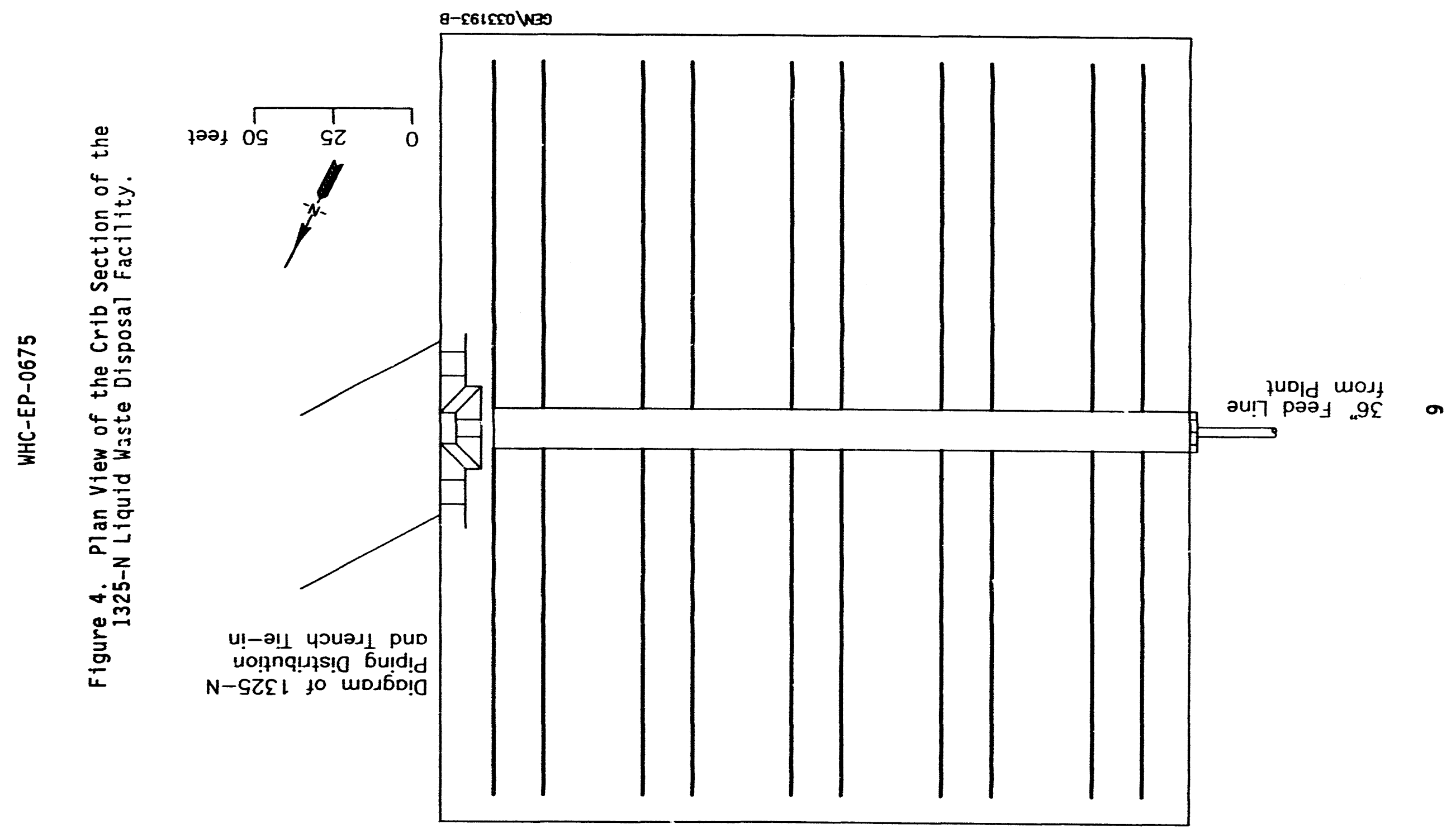




\section{$2.3 .21301-N$ LWDF}

The 1301-N LWDF also is a crib and trench facility (see Figure 2) that is constructed within the boundaries of the 100-N Area perimeter fence. The crib is 88 by 38 by $4 \mathrm{~m}$ (290 by 125 by $12 \mathrm{ft}$ ), and is filied with a $1-\mathrm{m}(3-\mathrm{ft})$ layer of boulders. Precast concrete cover panels were placed over the trench in 1982 to minimize both intrusion by wildlife and airborne contamination from the facility (DOE-RL 1991a). The zig-zag extension trench is 488 by 15 by $4 \mathrm{~m}$ $(1,600$ by 50 by $12 \mathrm{ft})$. The trench was added to the crib in 1965 because wastewater volume exceeded the capacity of the crib. The 1301-N LWDF began operation in 1965 and was used until September 1985 (DOE-RL 1991a).

\subsubsection{4-N/NA Surface Impoundment/Percolation Pond}

2.3.3.1 1324-NA Percolation Pond (1324-NA Pond). The 1324-NA Pond is a large unlined percolation pond located approximately $914 \mathrm{~m}(3,000 \mathrm{ft})$ from the 105-N Building (see Figure 2). The pond was placed in service in August 1977 , and was used to treat corrosive regeneration effluent from the

163-N Demineralization Plant and filter backwash water from the 183-N Filtered Water plant. The corrosive effluent was treated in the pond by alternating the addition of acidic cation column regeneration effluent and alkaline anton column regeneration effluent, ihich neutralized the solutions. The pond also was to make use of the natural buffering capacity and calcareous nature of the soil underlying the pond to neutralize the waste (DOE-RL 1991a). However, no analytical data exist to verify the exact buffering capacity of the 100-N soil column.

In the spring of 1983, the 1324-NA Pond was enlarged from a bottom area of $855 \mathrm{~m}^{2}\left(9,200 \mathrm{ft}^{2}\right)$ with a volume of approximately $4,542,480 \mathrm{~L}$ $(1,200,000 \mathrm{gal})$ to a bottom area of $2,694 \mathrm{~m}^{2}\left(29,000 \mathrm{ft}^{2}\right)$ with a volume of $11,356,200 \mathrm{~L}(3,000,000 \mathrm{gal})$. The filter backwash was routed to the Backwash Lake disposal site at this time (see Figure 2). Use of the 1324-NA Pond to treat dangerous wastes was discontinued in May 1986, when the 1324-N Surface Impoundment was put into service to treat the corrosive effluents (DOE-RL 1991a).

This facility was used from 1986 to 1988, when it was replaced by an elementary neutralization unit located at the 163-N Demineralization Plant. From 1986 until present, the pond has received the neutralized regeneration effluent from the elementary neutralization unit (DOE-RL 1991a).

2.3.3.2 1324-N Surface Impoundment (1324-N). The 1324-N Facility is a double-lined pond with leachate collection and leak detection systems, located $914 \mathrm{~m}(3,000 \mathrm{ft})$ southeast of the 105-N Building. The impoundment is approximately 43 by $23 \mathrm{~m}$ (140 by $75 \mathrm{ft}$ ) at grade and slopes to 24 by $5 \mathrm{~m}$ ( 80 by $15 \mathrm{ft}$ ) below grade $(5 \mathrm{~m}[15 \mathrm{ft}]$ ) and is designed to hold $1,605,001 \mathrm{~L}$ (424,000 gal) (UNC 1987). The 1324-N Facility was used to treat and neutralize corrosive wastes before they were discharged to the 1324-NA Pond (UNC 1987). The 1324-N Surface Impoundment was constructed in 1986 and used until 1988. No leaks have been detected from this site. 


\subsubsection{5-N Reactor}

The 105-N Reactor Building housed a graphite-moderated, light watercooled, horizontal-pressure tube nuclear reactor. The reactor coolant circulating pumps were single-stage, horizontal centrifugal pumps with highpressure water injection seals to prevent reactor coolant loss (WHC 1989a). The reactor was designed to operate in two modes: (1) production of special nuclear material only, and (2) production of special nuclear material and byproduct steam (which was used by the Hanford Generating Plant to produce electricity). When the reactor was producing special nuclear material only, steam from the secondary side of 10 steam generators was routed through 16 river water-cooled dump condensers. Condensate from these condensers was routed back into the steam generators for regeneration. Under dual-purpose operation, the steam was supplied to the Hanford Generating Plant to produce 860 MW of electrical power (WHC 1989a).

\subsubsection{9-N Heat Exchanger}

The portion of the reactor coolant system within the 105-N Building consists of 16 parallel lines that conducted cooling water from an inlet water manifold in the 109-N Heat Exchanger building to the reactor. Each of these 16 lines ended in a vertical header to which 54 to 66 individual pressure tube header-to-inlet nozzle connectors were attached. Similar outlet risers and parallel lines conducted the coolant from the pressure tube outlet nozzle-to-header connectors to an outlet water manifold (WHC 1989a).

In the 109-N Building, which is immediately adjacent to the 105-N Building, the reactor coolent system consisted of six cells in parallel, each containing two steam generators also in parallel, a circulating pump and associated valves, and instrumentation. Piping and steam generators in each of the six cells could be isolated from the main header piping by means of isolation valves (WHC 1989a). 
WHC-EP-0675

,

This page intentionally left blank. 
WHC-EP-0675

\section{$3.0 \quad 1325-N$ LWDF EFFLUENT CHARACTERISTICS}

\subsection{SOURCES}

The source of effluent to the 1325-N LWDF was the 105-N and 109-N Facilities. The waste streams changed over time, because of the shutdown of some of the operations in the 100-N Area. There were five major waste streams from these facilities routed to the 1325-N LWDF:

- Reactor coolant system bleedoff

- Spent fuel storage basin cooling water overflow

- Reactor periphery cooling systems bleedoff

- Reactor primary coolant loop decontamination rinse solution

- Building drains containing radioactive wastes generated from reactor support facilities.

Table 1 is a listing of the various effluent stream sources and types for the 1325-N LWDF.

\subsection{SYSTEM CONFIGURATION AND OPERATION}

The 1325-N LWDF received effluent from the facilities listed in Table 2; the facilities' physical layout is shown in Figure 5 . The facilities described above are connected by underground piping. The $\mathrm{N}$ Reactor effluent discharged to the 1325-N LWDF through the 91.4-cm- $(36-\mathrm{in} .-)$ diameter lowpressure flush line (FL[LP]) (Figure 6). Effluent sources (Figure 7), including various floor drains and the fuel basin overflow weirs, drained into the lift station pump well on the west side of the 105-N Facility. From the lift station, the wastewater was pumped to the 1325-N LWDF through the 91.4-cm- (36-in.-) diameter FL(LP). The emergency dump tank discharged into the 91.4-cm- (36-in.-) diameter $F L(L P)$, just north of the lift station, via the 76.2-cm- (30-in.-) diameter overflow drain (Figure 8) (WHC 1990c).

Contaminated wastewater exited the east end of the 109-N Facility via the 15.2-cm- (6-in.-) diameter radioactive drain (RDR) and was routed to the 1310-N Facility (Figure 9). This line was designed to carry nuclear sump pump discharge and liquid waste from cell decontamination in the 109-N Facility. Currently the line carries intermittent flows of water collected from shop areas and air conditioning units within the facility (WHC 1990c).

The 25.4-cm- (10-in.-) diameter RDR routes wastewater from the west end of the 109-N Facility (see Figure 8 ), around the west end of the 105-N Facility, and through the 1909-N Valve Pit. Just east of the 1909-N Valve Pit, the 25.4-cm- (10-in.-) diameter RDR increases to $30.5 \mathrm{~cm}$ (12 in.) in diameter and runs alongside the $91.4-\mathrm{cm}-(36-i n .-)$ diameter FL(LP) until it reaches the 1301-N Weir Box. The stream carried by the $30.5-\mathrm{cm}-$ (12- in.-) diameter RDR can be diverted to the 1310-N Facility at the 
Table 1. Past and Present Effluent Stream Sources and Amounts Discharged to the 1325-N Liquid Waste Disposal Facility (adapted and modified from Diediker and Hall [1987]). (2 sheets)

\begin{tabular}{|c|c|c|c|c|c|}
\hline \multirow{2}{*}{ Waste stream origin } & \multirow{2}{*}{$\begin{array}{l}\text { Rel ease } \\
\text { period }\end{array}$} & \multirow{2}{*}{ Effluent/frequency } & \multirow{2}{*}{ Frequency } & \multicolumn{2}{|c|}{ Amounts } \\
\hline & & & & $\begin{array}{c}\text { Peak reactor } \\
\text { operations }\end{array}$ & Present Limit \\
\hline Reactor coolant system bleedoff & $\begin{array}{l}1983- \\
1990\end{array}$ & $\begin{array}{l}\text { - Demineralized water treated } \\
\text { with ammonium hydroxide and } \\
\text { hydrazine }\end{array}$ & Cont inuous & $\begin{array}{l}757 \mathrm{~L} / \mathrm{min} \\
(200 \mathrm{gal} / \mathrm{min}) \\
\text { bleedoff and } \\
\text { leakage }\end{array}$ & $\begin{array}{l}\text { Less than or equal } \\
\text { to } 8 \mathrm{~L} / \mathrm{min} \\
(2 \mathrm{gal} / \mathrm{min}) \\
\text { averaged over the }\end{array}$ \\
\hline $\begin{array}{l}\text { Spent fuel storage basin cooling } \\
\text { water overflow }\end{array}$ & $\begin{array}{l}1983- \\
1991 \\
\end{array}$ & $\begin{array}{l}\text { - Filtered water with chlorine } \\
\text { added as an algicide }\end{array}$ & $\begin{array}{l}\text { Cont ingency, } \\
\text { overflow }\end{array}$ & Varied & $\begin{array}{l}\text { cal endar month; } \\
\text { not to exceed } \\
6.8 \text { million L }\end{array}$ \\
\hline $\begin{array}{l}\text { Reactor periphery cooling systems } \\
\text { bleedoff } \\
\text { - Graphite and shield cooling } \\
\text { - Reactor control rod cooling } \\
\text { - Reactor secondary coolant loop }\end{array}$ & $\begin{array}{l}1983- \\
1990 \\
1983- \\
1990 \\
\\
1983- \\
1990\end{array}$ & $\begin{array}{l}\text { - Demineralized water treated } \\
\text { with ammonium hydroxide and } \\
\text { hydrazine } \\
\text { - Demineralized water treated } \\
\text { with ammonium hydroxide and } \\
\text { hydrazine } \\
\text { - Demineralized water treated } \\
\text { with morphol ine and hydrazine }\end{array}$ & $\begin{array}{l}\text { Cont inuous, all } \\
\text { sources }\end{array}$ & $\begin{array}{l}\text { Bleedoff and } \\
\text { spillage, all } \\
\text { sources }\end{array}$ & $\begin{array}{l}\text { (1.8 million gal) } \\
\text { total to } \\
\text { June 1995, all } \\
\text { sources }\end{array}$ \\
\hline $\begin{array}{l}\text { Reactor primary coolant loop } \\
\text { decontamination rinse solution }\end{array}$ & $\begin{array}{l}1983- \\
1987\end{array}$ & $\begin{array}{l}\text { IURCo }{ }^{a} \text { ( } 70 \% \text { phosphoric acid), } \\
\text { diethyl thiourea, and } \\
\text { demineral ized water }\end{array}$ & $\begin{array}{l}\text { Once every } 2 \text { to } \\
4 \text { years }\end{array}$ & $\begin{array}{l}\text { Decon solution: } \\
\text { (1) } 79,493 \mathrm{~L} \\
\text { (21,000 gal) } \\
\text { TURCo, (2) } 136 \text { to } \\
181 \mathrm{~kg} \text { ( } 300 \text { to } \\
400 \text { (b) diethyl- } \\
\text { thiourea; diluted } \\
\text { to } 8 \text { wt\% phosphoric } \\
\text { acid using } \\
\text { demineral ized water }\end{array}$ & \\
\hline
\end{tabular}


Table 1. Past and Present Effluent Stream Sources and Amounts Discharged to the 1325-N Liquid Waste Disposal Facility (adapted and modified from Diediker and Hall [1987]). (2 sheets)

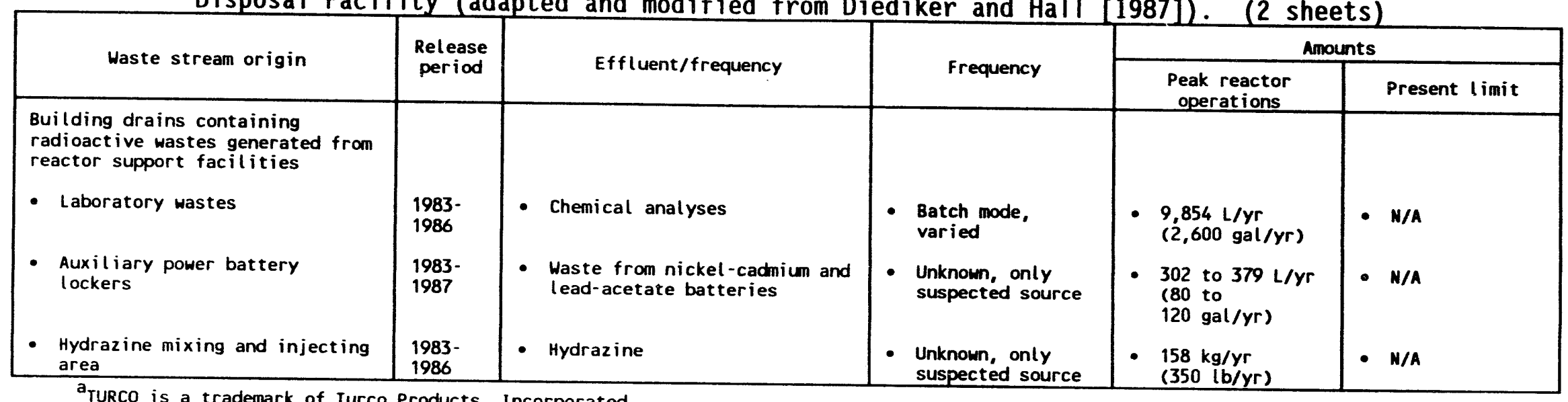

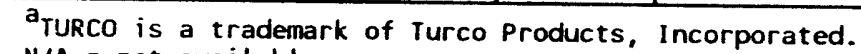

$N / A=$ not available. 
Table 2. Facilities that Drain to the 1325-N Liquid Waste Disposal Facility (WHC 1990C).

\begin{tabular}{|c|c|c|}
\hline Facility & Facility description & $\begin{array}{l}\text { Connection to the } 1325-N \text { LWDF } \\
\text { (cm in diameter [in. in diameter }] \text { ) }\end{array}$ \\
\hline $105-\mathrm{N}$ & Reactor Facility & $91.4 \mathrm{~cm}$ (36 in.) FL(LP) \\
\hline $109-N$ & Heat Exchanger Building & $25.4 \mathrm{~cm}(10$ in. $) ; \operatorname{RDR} 30.5 \mathrm{~cm}(12-$ in. $)$ \\
\hline $1301-N$ & Liquid Waste Disposal Facility and Weir Box & $91.4 \mathrm{~cm}(36$ in.) FL(LP) \\
\hline $1304-N$ & Emergency Dump Tank & $\begin{array}{l}91.4 \mathrm{~cm} \text { ( } 36 \text { in.); Overflow to } 91.4 \mathrm{~cm} \\
\text { ( } 36 \mathrm{in.}) \mathrm{FL}(\text { LP })\end{array}$ \\
\hline $1310-\mathrm{N}$ & Radioactive Chemical Waste Treatment Facility & $30.5 \mathrm{~cm}(12$ in.); RDR $61 \mathrm{~cm}(24$ in.) \\
\hline $1315-N$ & Reactor Effluent Diversion System Valve House & $91.4 \mathrm{~cm}$ (36 in.) FL(LP) \\
\hline $1316-N$ & Valve House & $91.4 \mathrm{~cm}(36$ in.) $\mathrm{FL}(\mathrm{LP})$ \\
\hline 1316-NA & Valve Vault Building & $91.4 \mathrm{~cm}(36$ in.) FL(LP) \\
\hline 1316-NB & Magnet ic Flow Meter Vault & $91.4 \mathrm{~cm}(36$ in.) FL(LP) \\
\hline $1316-N C$ & Turbine Flow Meter Vault & $91.4 \mathrm{~cm}$ (36 in.) FL(LP) \\
\hline $1322-N$ & Waste Treatment Pilot Plant and Valve Pit & $91.4 \mathrm{~cm}(36$ in.) $F L(L P) ; \operatorname{RDR} 30.5 \mathrm{~cm}(12$ in.) \\
\hline 1322-NA & Effluent Water Pilot Plant & $91.4 \mathrm{~cm}(36$ in.) FL(LP); RDR $30.5 \mathrm{~cm}$ (12 in.) \\
\hline 1322-NB & Crib Effluent lodine Monitoring Facility & $91.4 \mathrm{~cm}(36$ in.) FL(LP); RDR $30.5 \mathrm{~cm}(12$ in.) \\
\hline $1322-N C$ & Crib Sample Pump Pit & $91.4 \mathrm{~cm}$ (36 in.) FL(LP); RDR $30.5 \mathrm{~cm}(12 \mathrm{in.})$ \\
\hline $1327-N$ & Valve House & $91.4 \mathrm{~cm}(36$ in.) FL(LP) \\
\hline $1723-N$ & $\begin{array}{l}\text { Materials Receiving, Inspection, and Storage } \\
\text { Building }\end{array}$ & $10.2 \mathrm{~cm}$ ( 4 in.) cold drain \\
\hline $1909-N$ & Waste Disposal Valve Pit & $25.4 \mathrm{~cm}(10$ in. $) ; \operatorname{RDR} 30.5 \mathrm{~cm}$ (12 in.) \\
\hline
\end{tabular}

$F L(L P)=$ low-pressure flush line.

RDR = radioactive drain. 
Figure 5. Layout of the 100-N Area (WHC 1990C).

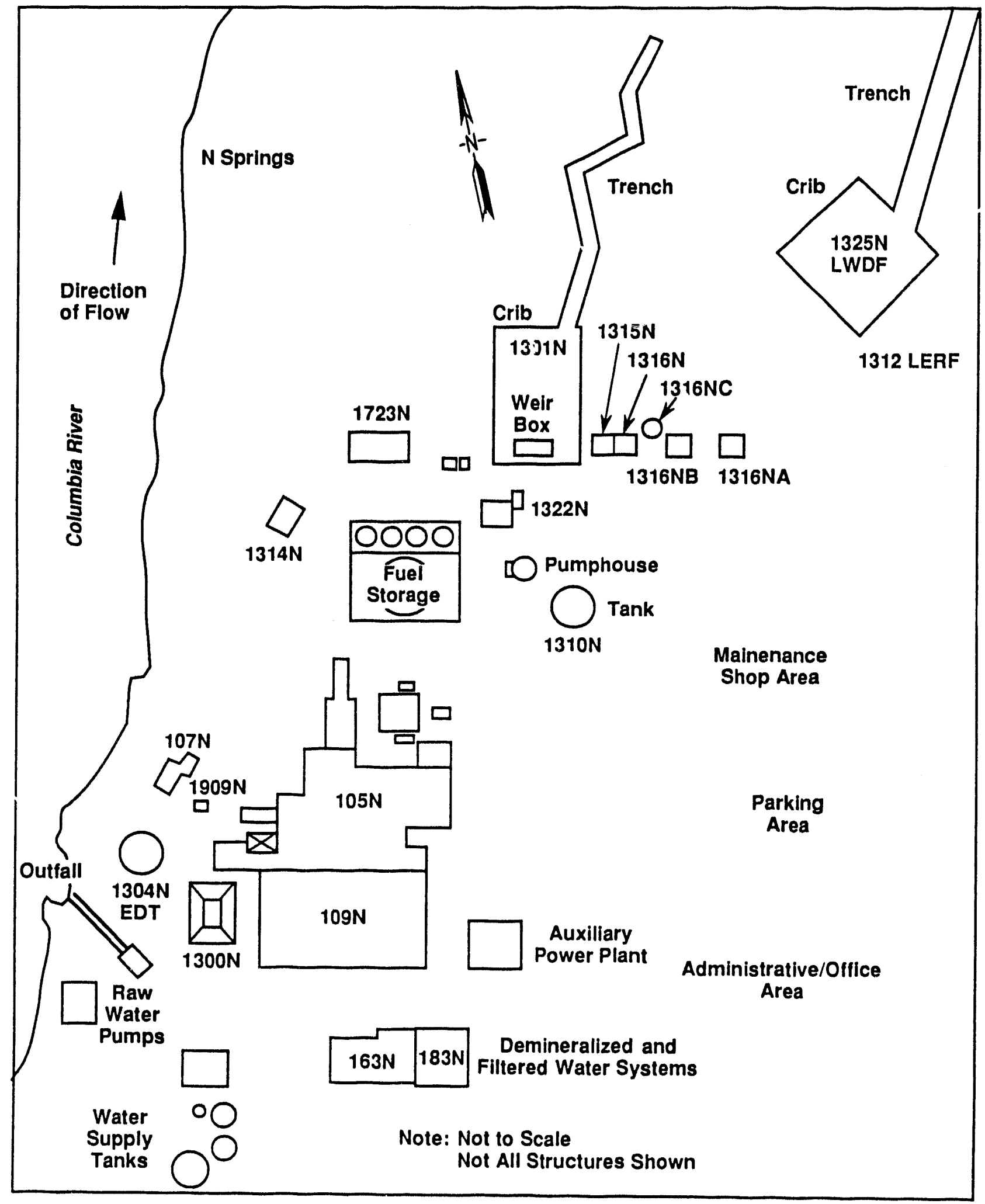


Figure 6. Route of $N$ Reactor Effluent to the 1325-N Liquid Waste Disposal Facility via the $91.4-\mathrm{cm}-(36-\mathrm{in} .-)$

Diameter Low-Pressure Flush Line (WHC 1990C).

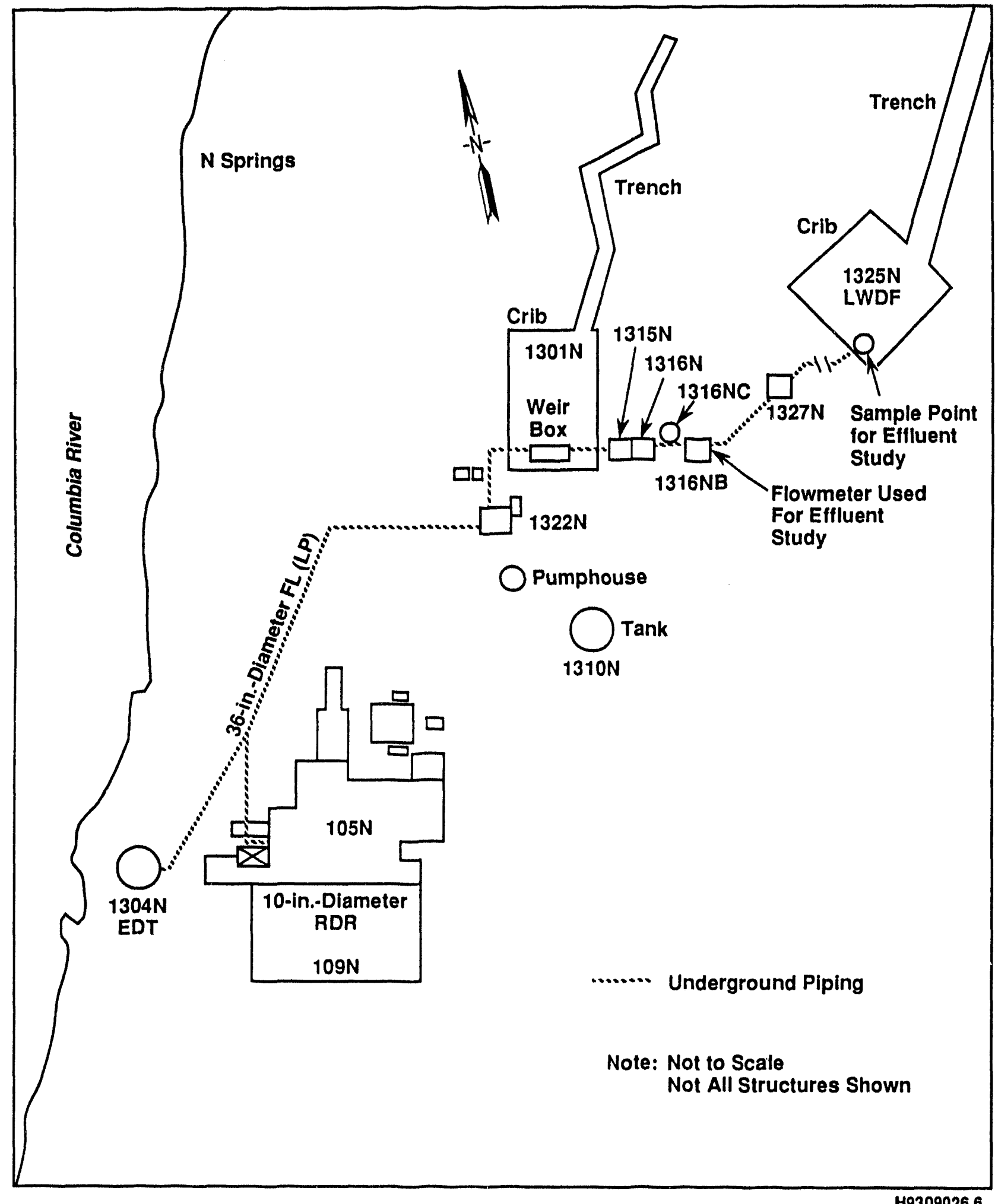


Figure 7. Schematic of $N$ Reactor Effluent Discharged to the 1325-N Liquid Waste Disposal Facility (WHC 1990C).

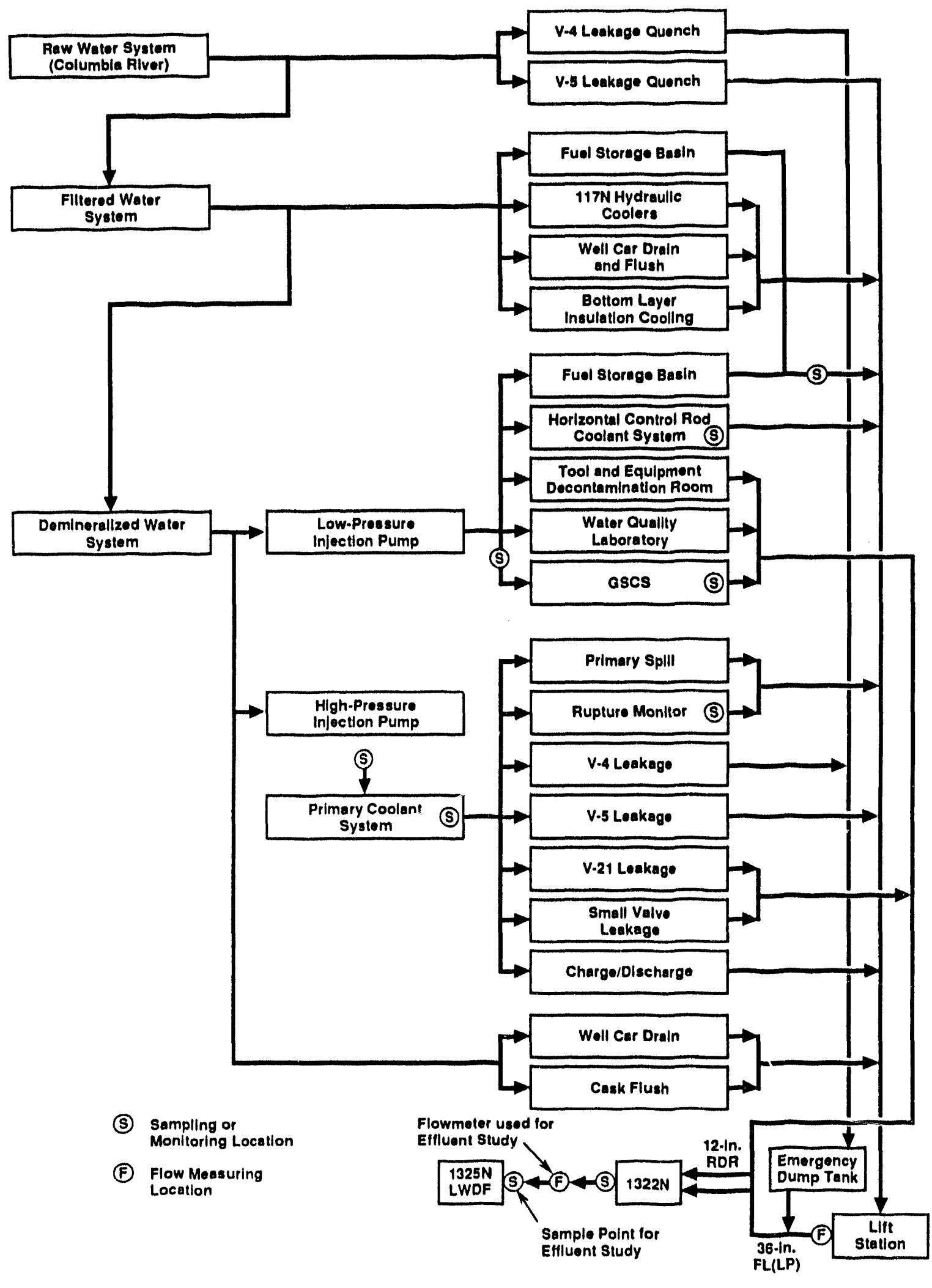

H9309026.2 


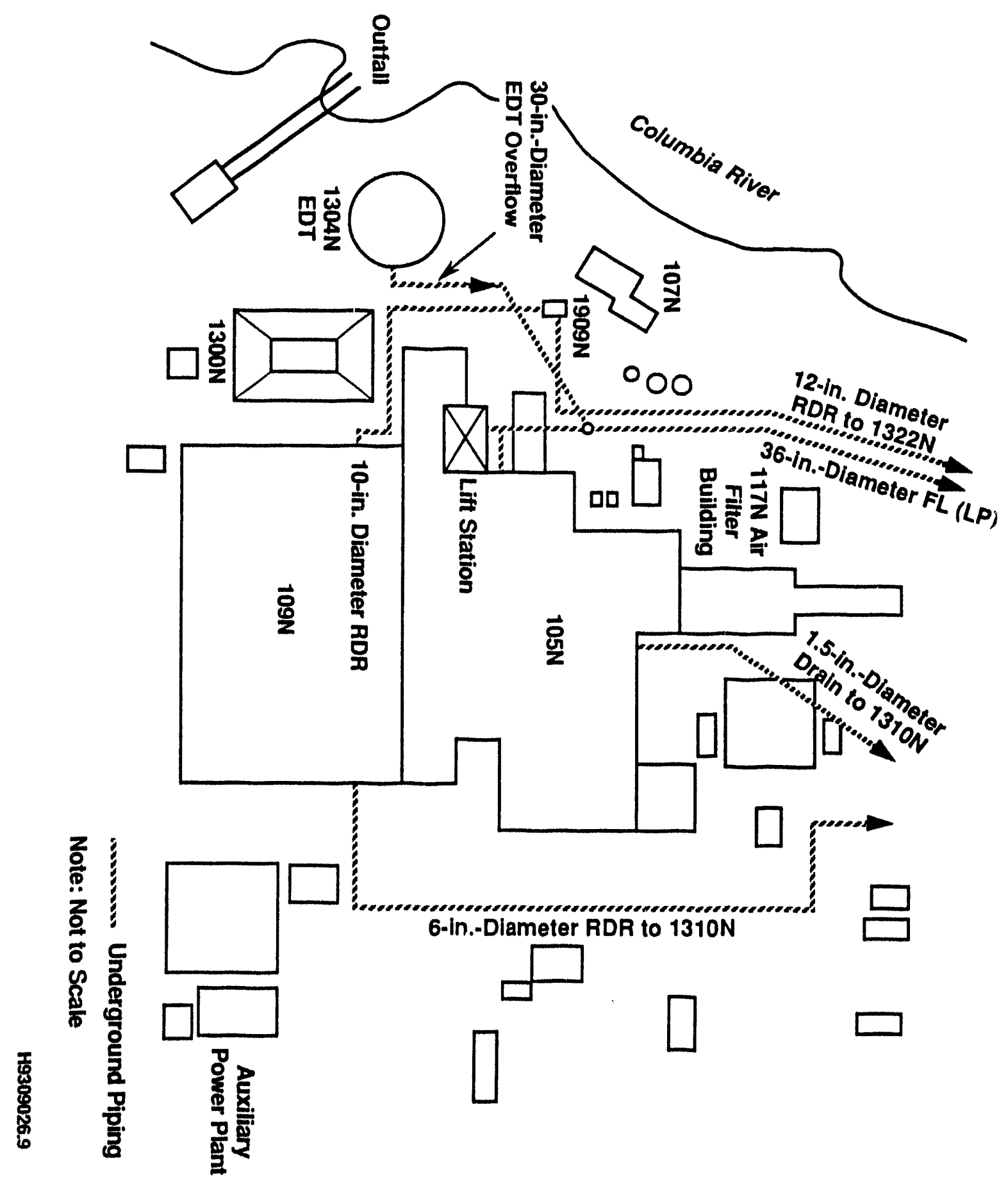

- (2066I JHM) so!z!llore

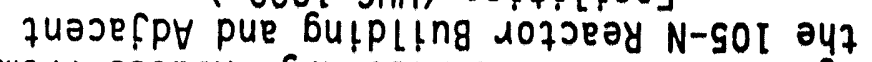
wout saznoy abseyosio quanlft] '8 axnbif 
Figure 9. Effluent Discharge Routes to the 1314-N Liquid Waste Railcar Loadout Station During Various Decontamination Activities (WHC 1990C).

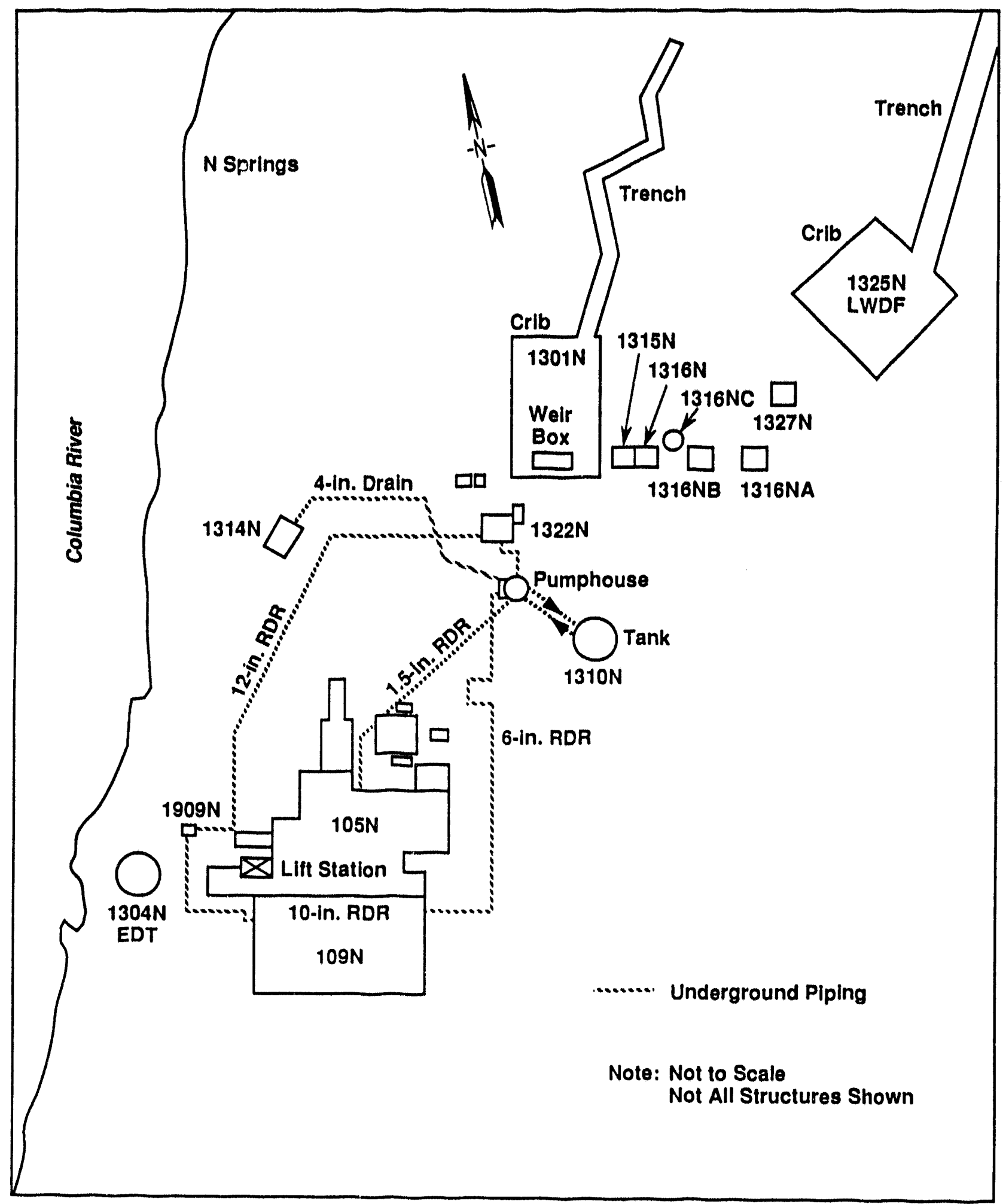


1322-N Facility. This option was used during a major plant decontamination (see Figure 9). This radioactive drain currently carries a small, continuous flow from cell sumps in the 109-N Factlity (WHC 1990 C).

The 10.2-cm- (4-in.-) diameter chemical waste line discharged from the 1310-N Facility to the 1314-N Loadout Facility. This provided a means of disposing of liquid wastes generated during decontamination activities, whici were more concentrated or corrosive than the usual $\mathrm{N}$ Reactor effluent discharged to 1325-N LWDF (WHC 1990C).

\subsection{DISCHARGE VOLUME AND FLOW REGIME}

During peak reactor operations the flow rate out to the 1325-N LWDF ranged from 3,785 to $6,057 \mathrm{~L} / \mathrm{min}$ (1000 to $1,600 \mathrm{gal} / \mathrm{min}$ ) and could increase to $7,570 \mathrm{~L} / \mathrm{min}(2,000 \mathrm{gal} / \mathrm{min})$ during specific operations. Since Apri1 1991, there has been no discharge to the facllity. There are no plans to resume discharge to the factlity on a regular basis and all discharges to the facility are required to be terminated by June 1995 (in accordance with Tri-Party Agreement Milestone M-17-15A). However, the facility may need to be used on an emergency basis before that time, for discharge of fire protection water. If there is further discharge to the facility, the following limits are in effect in accordance with Tri-Party Agreement Milestone M-17-15A:

- Flow rate must be less than or equal to $7.6 \mathrm{~L} / \mathrm{min}(2 \mathrm{gal} / \mathrm{min})$ averaged over the calendar month

- Maximum discharge amount allowed to the facility from the present time until June 1995 is $6,813,741 \mathrm{~L}(1,800,000 \mathrm{gal})$.

The maximum amount of effluent that could be discharged in an average month would be:

30 days $\times 1,440 \mathrm{~min} /$ day $=43,200$ minutes

$(43,200$ minutes $\times 7.6 \mathrm{~L} / \mathrm{min}=328,320 \mathrm{~L})$ 43,200 minutes $\times 2 \mathrm{gal} / \mathrm{min}=86,400 \mathrm{gal}$.

Thus, the maximum amount that could be discharged in a given month is $328,320 \mathrm{~L}(86,400 \mathrm{gal})$.

\subsection{EFFLUENT CONSTITUENTS}

\subsubsection{Quantities}

The total effluent discharged to the 1325-N LWDF from January 1983 to Apr 111991 is $7,305,844,743 \mathrm{~L}(1,930,000,000 \mathrm{gal})$. Table l explains these numbers in more detail. 
WHC-EP-0675

\subsubsection{Loading Rates}

The information in this section was adapted from the Closure/Post-Closure Plan for the 1301-N and 1325-N Liquid Waste Disposal Facilities (Diediker and Hall 1987) and the Liquid Effluent Study Final Project Report (WHC 1990a). This section contains actual and potential waste sources for the 1325-N LWDF treatment, storage, and disposal unit as well as radiological and chemical loading estimates (Table 3 ).

3.4.2.1 Estimate of Nondangerous Waste. This section is summarized from Diediker and Hall (1987). The major portion of the effluent discharged to the 1325-N LWDF (from 1983 to April 1991) has come from the 105-N/109-N Facilities. The five identified waste streams that emanate from these facilities were sampled at the point of discharge into the 1325-N LWDF (Table 4). The results indicated that the effluent did not exhibit any of the characteristics of a dangerous waste. None of the results met the criteria to be designated dangerous wastes, as 1 isted in Washington Administrative Code

(WAC) $173-303-090$.

3.4.2.2 Estimate of Potential Dangerous Waste. This section is summarized from Diediker and $\mathrm{Hall}$ (1987) and addresses the potential for dangerous wastes to have been discharged to the 1325-N LWDF. The following potentlally dangerous waste constituents were identified using process knowledge and historical information: (1) ammonium hydroxide, (2) hydrazine, (3) chlorine, (4) morpholine, (5) TURCO 4512-A (70\% phosphoric acid), (6) chemical laboratory wastes, and (7) nickel-cadmium and lead-acetate batteries. The estimated maximum potential volume of dangerous wastes received by the 1325-N LWDF is given in Table 1. Each of these constituents will be discussed in the following sections as part of the waste stream that produces it.

3.4.2.2.1 Reactor Primary Coolant System. The reactor primary coolant system was supplied by demineralized water with chemicals added for water quality control. The chemicals that were introduced into the primary coolant system were ammonium hydroxide and hydrazine. Ammonium hydroxide was used for $\mathrm{pH}$ control and was injected at a concentration of approximately 40 parts per million (ppm) to maintain a pH of 10.2 to 10.4. Hydrazine was introduced for oxygen control at a concentration of $0.04 \mathrm{ppm}$. Normal operation of the reactor primary coolant system resulted in approximately $757 \mathrm{~L} / \mathrm{min}$

$(200 \mathrm{gal} / \mathrm{min})$ of bleedoff and leakage that was discharged to the 1325-N LWDF. Concentration of chemicals used in maintaining the water quality of the primary coolant system was very low at the point of discharge to the 1325-N LWDF. Their influence was nondetectable and the waste stream did not exhibit any of the characteristics of a dangerous waste because of these chemicals.

3.4.2.2.2 Fuel Storage Basin Cooling Water. The spent fuel storage was supplied by filtered water treated with chlorine (as an algicide). A trace amount of residual chlorine was maintained to ensure complete treatment. The overflow did not contain hazardous chemical constituents and therefore had no impact on the dangerous waste designation of wastes discharged to the

${ }^{1}$ TURCO $4512-A$ is a trademark of Turco Products, Incorporated. 
Table 3. Radionuclide and Chemical Loading, N Reactor Effluent (WHC 1990a).

\begin{tabular}{|c|c|c|c|c|c|}
\hline Conseltuent & $\mathrm{kg} / \mathrm{L}$ & $\mathrm{kg} /$ month & Conet I tuent: & $\mathrm{kg} / \mathrm{l}$ & kg/month \\
\hline Bartum & $3.67 \mathrm{E}-08$ & $1.82 x+00$ & Unknown olycol & $2.80 E \cdot 08$ & $1.39 E+00$ \\
\hline Boron & $6.12=-08$ & $3.03 E+00$ & Unknown hydrocarbon & $1.90 \mathrm{E}-07$ & $9.41 E+00$ \\
\hline Cectulum & $2.00 E-09$ & $9.90 \leq-02$ & Unknown oxygennted PAH & 9.008 .09 & $4.45 E-01$ \\
\hline Calcive & $1.16=-05$ & $5.74 E+02$ & Unknown phthalate & $9.00 E-09$ & $4.45 E-01$ \\
\hline Chloride & $1.13=-06$ & $5.59 t+01$ & Alphe ectivity & $2.94 E-11$ & $1.46 E-03$ \\
\hline Fluoride & $1.48 \mathrm{E} \cdot 07$ & $7.336+00$ & Bete ectivity & $7.03 \mathrm{E}-0 \mathrm{~s}$ & $3.48 E+00$ \\
\hline Iron & $2.53 E-07$ & $1.25 \mathrm{E}+01$ & Total dissolved sollds & $3.97 \mathrm{E}-05$ & $1.97 E+03$ \\
\hline Magnealun & $2.90 \mathrm{E} .06$ & $1.44 E+02$ & Total organic carbon & $7.25 E-07$ & $3.59 E+01$ \\
\hline Mangenese & $6.75 E .09$ & $3.34 E+01$ & Potal carbon & $8.53 \mathrm{E}-06$ & $4.22 E+02$ \\
\hline Nitrate & $4.02 E=07$ & $1.90 E+01$ & rox (as chloride) & $1.80 \mathrm{E} \cdot 08$ & $8.91 \mathrm{E} \cdot 01$ \\
\hline Potaseniun & $4.75=.07$ & $2.35 E+01$ & Americium-261" & $3.48 \mathrm{E} \cdot 11$ & $1.72 \mathrm{E}-03$ \\
\hline sliticen & $1.48 \mathrm{E}-06$ & $7.33 \mathrm{E}+01$ & curiun-242 & $1.67 E-13$ & $8.27 E-06$ \\
\hline sodiun & $1.53 \mathrm{E}-06$ & $7.578+01$ & Curfiun-244" & $3.68 \mathrm{E}-13$ & $1.82 \mathrm{E}-05$ \\
\hline serontiun & $3.95=-08$ & $2.95 E+00$ & Cobol te.60 & $4.36 E-10$ & $2.16 \mathrm{E}-02$ \\
\hline sulfote & $1.06 \times-05$ & $3.25 \mathrm{E}+02$ & Cosiun-134" & $9.43 E-11$ & $4.67 E-03$ \\
\hline Ureniven & 1.96 E.09 & $9.70 E-02$ & Cosium-137 & $2.29 E-08$ & $1.13 E+00$ \\
\hline Zine & $1.07 E \cdot 08$ & $3.30 E \cdot 01$ & Carbon-14" & $2.22 \mathrm{E}-12$ & $1.10 E-04$ \\
\hline Acetone & $9.76 E-09$ & $4.84 E-01$ & Hydrogen-3 etritium)" & $1.02 \varepsilon-07$ & $5.05 \mathrm{E}-00$ \\
\hline Ammonis & $1.82=-07$ & $9.01 E+00$ & Menganese-54" & $3.19 E-10$ & $1.58 E-02$ \\
\hline Benzoic scid & $1.10 E-07$ & $5.45 E+00$ & Lead-210 & $1.22 E-12$ & $6.04 E-05$ \\
\hline 1-butenol & $2.70 E \cdot 08$ & $1.34 E+00$ & Plutenium-238 & $4.82 \mathrm{E}-12$ & $2.39 E-04$ \\
\hline 2-butanon & $1.72 E-08$ & $8.51 E-01$ & Plutonium-239/260 & $3.62 \mathrm{E}-11$ & $1.79 \mathrm{E} \cdot 03$ \\
\hline $\begin{array}{l}\text { Butylated } \\
\text { hydroxy toluene }\end{array}$ & $1.07 \mathrm{E}=08$ & $5.30 \mathrm{E}=01$ & Radium-total" & $1.78 E-13$ & $8.81 E-06$ \\
\hline Hydrazino & 3.05 E-08 & $1.51 E+00$ & Ruthenium-106 & $4.63 E-10$ & $2.29 E-02$ \\
\hline MIBK (hoxone) & $1.01 E-08$ & $3.00 \mathrm{E} \cdot 01$ & strontiun-90 & $8.40 \mathrm{E} \cdot 08$ & $4.16 E+00$ \\
\hline Toluen & $5.08 \varepsilon .09$ & $2.51 E-01$ & Uraniun-234" & $1.34 E \cdot 12$ & $6.63 \mathrm{E}-05$ \\
\hline Trichloramthen & $4.85 E-09$ & $2.40 \mathrm{E}-01$ & Uranín-235" & $1.51 E-13$ & $7.47 \mathrm{E}-06$ \\
\hline Unknown & $4.70 E-08$ & $2.33 E+00$ & Uranium-238 & $9.12 E-13$ & $4.51 \mathrm{E}-05$ \\
\hline
\end{tabular}

Notes: (1) Date collected fram October 1989 through March 1990.

(2) Flow rate is the overage of rates from the $\perp$ Reactor Effluent stream-specific Repors (HHC 1990c, Addendum 3 ).

(3) Constituent concentrations are average valuas from the statistics in the 1 Resector Effluent strem-spaciffic Bepors (WHC 1990c, Addendum 3). concentration units of these conseftuents are reported as curies per liter. Loading units of these constituents ore reported es curles par month.

MIBK = methyl isobutyl ketone.

PAH - polycyclic orcmatic hydrocarbon.

TOX * total organic halogen. 
Table 4. 1325-N Liquid Waste Disposal Facility

Analysis (Diediker and Hall 1987). (2 sheets)

\begin{tabular}{|c|c|c|c|c|}
\hline \multirow{2}{*}{ Paraminter (MOL) } & \multicolumn{4}{|c|}{ Sample } \\
\hline & 1 & 2 & 3 & Average \\
\hline PH (standard units) & 6.58 & 6.56 & 6.97 & 6.70 \\
\hline Conduct Ivity (Mmhos/cm) & 148 & 155 & 190 & 164 \\
\hline Morcury (0.001 ppm) & LD & LD & LO & LD \\
\hline Ethylene olycol (10 ppm) & 10 & LD & Lo & LD \\
\hline $\begin{array}{l}\text { Enhenced thicurea } \\
(0.2 \text { pew) }\end{array}$ & LD & LD & LD & LD \\
\hline roc (1 ppm) & 0.00184 & 0.00200 & 0.00205 & 0.00197 \\
\hline Cyenide (0.01 pom) & LD & LD & LD & LD \\
\hline Bariun (0.006 ppm) & 0.030 & 0.027 & 0.027 & 0.028 \\
\hline Cachiviu (0.002 ppm) & 60 & LO & LO & LD \\
\hline Chromiun (0.01 ppm) & LD & LD & LD & LO \\
\hline Lead (0.03 ppm) & LO & LD & LD & LD \\
\hline silver (0.01 ppm) & LD & LD & LD & LD \\
\hline sodiun (0.1 ppm) & 1.831 & 1.819 & 1.781 & 1.810 \\
\hline Nickal (0.01 ppm) & LD & LD & LD & LD \\
\hline Copper (0.01 ppon) & LD & LD & LD & LD \\
\hline Vanedilum (0.005 ppm) & LD & LD & LD & LD \\
\hline Ant inony (0.1 pom) & LD & LO & LD & LD \\
\hline Aluminum (0.15 ppem) & LO & LD & LO & LD \\
\hline Manganese $(0.005 \mathrm{ppm})$ & LD & LD & LD & LD \\
\hline Potessive (0.1 ppm) & 0.647 & 0.608 & 0.606 & 0.620 \\
\hline Iron (0.05 ppm) & 0.081 & 0.077 & 0.050 & 0.069 \\
\hline Beryllium (0.005 ppm) & LO & LD & LD & LD \\
\hline Oamine (0.3 ppm) & 10 & LD & LD & LD \\
\hline strontiun (0.3 ppm) & LD & LD & LD & LD \\
\hline Zine $(0.005 \mathrm{ppm})$ & LO & LD & LD & LD \\
\hline Colciun (0.05 ppm) & 14.400 & 13.970 & 14.050 & 14.140 \\
\hline Nitrate $(0.5 \mathrm{ppm})$ & LD & LD & LD & LD \\
\hline Sulfate $(0.5 \mathrm{ppm})$ & 12.416 & 11.532 & 11.970 & 11.973 \\
\hline Fluoride (0.5 ppm) & LD & LD & LD & LD \\
\hline Chloride (0.5 ppm) & 1.578 & 1.478 & 1.533 & 1.530 \\
\hline Phosphate (1 ppm) & LD & LD & LD & LD \\
\hline $\begin{array}{l}\text { Phosphorus pesticides } \\
(0.005 \text { ppm })\end{array}$ & LO & LD & LD & LO \\
\hline $\begin{array}{l}\text { Chlorinated pesticides } \\
(0.001 \mathrm{ppm})\end{array}$ & LO & LD & LD & LO \\
\hline Enhenced ABN list & LD & LD & LD & LD \\
\hline citrus red (1 ppm) & LD & LD & LD & LD \\
\hline Arsenic (0.005 ppm) & LD & LD & LD & LD \\
\hline Amoniun ion (0.05 ppm) & LO & LD & LD & LD \\
\hline
\end{tabular}


Table 4. 1325-N Liquid Waste Disposal Facility

Analysis (Diediker and Hall 1987). (2 sheets)

\begin{tabular}{|l|c|c|c|c|}
\hline \multirow{2}{*}{ Parameter (MDL) } & \multicolumn{3}{|c|}{ Sample } \\
\cline { 2 - 5 } & 1 & 2 & 3 & Average \\
\hline Coliform (3 MPN) & -0 & 0.023 & 0.009 & 0.016 \\
\hline Solenium $(0.005 \mathrm{ppm})$ & LD & LD & LD & LD \\
\hline Thallium $(0.01 \mathrm{ppm})$ & LD & LD & LD & LD \\
\hline
\end{tabular}

ABN = ecid-base neutrals.

LD = leas then detectable.

HOL = minimin detection limit.

MPN = most probeble number.

TOC a total organic carbon.

Note: Dota obtained from samples taken August 1985.

1325-N LWDF. Since December 1985, the spent fuel storage basin was supplied by demineralized water that does not contain chlorine.

3.4.2.2.3 Reactor Periphery Cooling Systems. Reactor periphery cooling systems that discharge bleedoff wastes to the 1325-N LWDF include the following:

- Graphite and shield cooling system--supplied by demineralized water with chemicals added for water quality control. Ammonium hydroxide was injected at a concentration of approximately $40 \mathrm{ppm}$ to maintain a $\mathrm{pH}$ of 10.0 to 10.2. Hydrazine was injected for oxygen control at a concentration of $0.04 \mathrm{ppm}$.

- Reactor control rod cooling system--recirculating system supplied by demineralized water with chemicals added for water quality control. Ammonium hydroxide was injected at a concentration of approximately $40 \mathrm{ppm}$ to maintain a pH of 7.0. Hydrazine was added for oxygen control at a concentration of $0.15 \mathrm{ppm}$.

- Reactor secondary coolant loop--supplied by demineralized water with chemicals added for water quality control. Morpholine was injected at a concentration of approximately $4 \mathrm{ppm}$ to maintain a pH of 8.6 to 9.2. Hydrazine was injected for oxygen control at a concentration of no greater than $1 \mathrm{ppm}$.

As with other reactor cooling systems, bleedoff and spillage from the periphery cooling systems resulted in small continuous discharges to the 1325-N LWDF. Sampling conducted on the 1325-N LWDF influent (see Table 4) indicates that the flow from these streams did not change the dangerous waste designation of wastes discharged to the 1325-N LWDF.

3.4.2.2.4 Reactor Primary Coolant Loop Decontamination. A decontamination of the reactor primary coolant loop was performed once every 2 to 4 years, as necessary. The decontamination solution is made up of $79,494 \mathrm{~L}$ $(21,000 \mathrm{gal})$ of TURCO $4512-\mathrm{A}$ (70\% phosphoric acid) and 136 to $181 \mathrm{~kg}$ (300 to 400 1b) of diethylthiourea. This solution was diluted to an 8 wt\% phosphoric acid solution as it entered the reactor coolant loop. 
The decontamination solution ar 1 concentrate rinse were disposed of through a system separate from the 1325-N LWDF, using a radioactive waste tank. After the $\mathrm{pH}$ of the rinsate had been verified between 6.0 and 9.0 , the final rinse solution, containing approximately $378,541 \mathrm{~L}(100,000 \mathrm{gal})$ of demineralized water, was discharged to the 1325-N LWDF.

Wastes received at the 1325-N LWDF from the reactor decontamination were extremely dilute (approximately one ten-thousandth of the original concentration of the decontaminated wastes). The calculated amount of phosphoric acid solution that was released to the 1325-N LWDF is $5.7 \mathrm{~L}$ ( $1.5 \mathrm{gal})$ per decontamination. The calculated amount of diethylthiourea released per decontamination was $2.3 \mathrm{~g}(0.08 \mathrm{oz})$. The decontamination rinse solution was not designated as a dangerous waste because the concentrations of the component chemicals were extremely low when the rinsate was diverted to the 1325-N LWDF.

3.4.2.2.5 Building Drains. The radioactive drain system was a network of floor drains that collected radioactive water from throughout the $109-\mathrm{N}$ and 105-N Facilities. Pump leakage and system bleedoff from the reactor primary and periphery cooling systems were transported to the 1325-N Facility via this system. Other contributing streams to this drain system were generated by laboratories, decontamination activities, and other routine functions at the $N$ Reactor. Of the wastes discarded to the radioactive drain system, three have exhibited characteristics of a dangerous waste.

Leaks and spills from the auxiliary power battery lockers have contributed 303 to $454 \mathrm{~L} / \mathrm{yr}$ ( 80 to $120 \mathrm{gal} / \mathrm{yr}$ ) of waste from nickel-cadmium and lead-acetate batteries. It is estimated that approximately $40 \%$ of the spilled material was from the nickel-cadmium batteries and $60 \%$ was from the lead-acetate batteries.

Spills of hydrazine from the hydrazine mixing and injection facilities are believed to have entered the radioactive drain system. Spills in this area were very small in volume and, in the case of the mixed solution, were extremely dilute. It is estimated that a maximum of $159 \mathrm{~kg} / \mathrm{yr}(350 \mathrm{lb} / \mathrm{yr})$ of hydrazine were spilled in this manner. The mixing area was curbed and isolated from the building drain in September 1986, thereby allowing spills to be contained, cleaned up, and disposed of in accordance with WAC 173-303 regulations.

Chemical analyses were performed in the laboratories to determine the amount of hydrazine, ammonia, chloride, and fluoride in the reactor coolant loop water. Waste characterization indicated that the solution discarded from these analyses (approximately 9,842 L/yr [2,600 gal/yr]) contained constituents that exhibited dangerous waste characteristics in accordance with WAC 173-303-090. Historically these solutions were discarded to the radioactive drain system, which discharges to the 1325-N LWDF. Since December 1986, all of these solutions were contained and disposed of in accordance with WAC 173-303 regulations.

Each of these wastes, at their point of introduction into the radioactive drain system, contain contaminants that are designated dangerous wastes in accordance with WAC 173-303-090. However, sampling conducted on the 1325-N LWDF influent (see Table 4) did not identify any dangerous waste characteristics at the point of discharge of the waste stream into the 
1325-N LWDF. The dangerous wastes that were being discharged to the 1325-N LWDF were controlled by the following means:

- Collected and disposed of in accordance with the "Dangerous Waste Regulations" (WAC 173-303)

- Controlled through improved secondary containment

- Controlled through the application of administrative controls to prevent the discharge of dangerous waste to the 1325-N LWDF.

\subsubsection{Operational Factors}

The $N$ Reactor effluent consisted primarily of cooling water and decontamination flush water used at various points within the system. Radioactive contamination of the wastewater contributors occurred during reactor operations. Sources of these radioactive constituents included activation products produced in the primary coolant system and fission products that result from occasional fuel cladding failures. Chemical contamination could occur if corrosion products and residuals remain in the system following reactor decontamination activities.

\subsection{CONSTITUENTS OF INTEREST AND KEY PARAMETERS}

The sample analytical data indicate that effluent discharges contain numerous radionuclides in concentrations which, in most cases, greatly exceed the WAC 173-200 Washington State Water Quality Standards (WWQS) concentration limits. Note that disposal to the crib began in 1983 but the old radiological data set included some samples taken before 1983. While concentrations of these constituents have decreased since the $N$ Reactor was placed in dry layup, concentrations of some radioactive constituents remain high as a result of residual contamination remaining in the system. The loading data indic te that tritium, strontium-90, and cesium-137 are the principal radionuclides discharged in excess of $1 \mathrm{Ci} /$ month (see Table 3 ).

The key constituents of interest identified in the Liquid Effluent Study Final Project Plan (WHC 1990a) are the long half-life radionuclides: tritium, cobalt-60, strontium-90, cesium-134, cesium-137, plutonium-238, plutonium-239, and americium-241. Of these parameters, only tritium, strontium-90, cobalt-60, and cesium-137 have exceeded the WWQS or equivalent radionuclide standards in effluent samples (WHC 1990a). 
WHC-EP-0675

\subsection{CONCEPTUAL MODEL OF HYDROLOGIC RESPONSE AND CONTAMINANT MIGRATION}

\subsection{HYDROGEOLOGIC FRAMEWORK}

\subsubsection{Regional and Hanford Site Geology}

The Pasco Basin and the Hanford Site are underlain by pre-Miocene sedimentary and crystalline rocks (Campbell 1989), Miocene-aged (17.5 to $6 \mathrm{Ma}$ ) basalts of the Columbia River Basalt Group (CRBG) (Myers et al. 1979; Reidel and Fecht 1981; DOE 1988; Tolan et al. 1989; Reidel et al. 1989, 1992) and interbedded sediments of the Ellensburg Formation (Reidel and Fecht 1981; DOE 1988; Smith 1988), and a late-Miocene- to Holocene-aged ( $<8.5 \mathrm{Ma}$ to present) suprabasalt sediment sequence (Myers et al. 1979; Tallman et al. 1981; DOE 1988; Smith et a1. 1989; Lindsey 1991a, 1991b; Reidel et al. 1992).

4.1.1.1 Columbia River Basalt Group. The CRBG is an assemblage of tholeiitic continental flood basalts that cover an area of more than $163,157 \mathrm{~km}^{2}\left(63,000 \mathrm{mi}^{2}\right)$ in Washington, Oregon, and Idaho, and have an estimated volume of about $174,356 \mathrm{~km}^{3}\left(40,800 \mathrm{mi}^{3}\right)$ (DOE 1988; Reidel and Hooper 1989; Tolan et al. 1989). The CRBG is divided, from oldest to youngest, into five formations: Imnaha Basalt, Picture Gorge Basalt, Grande Ronde Basalt, Wanapum Basalt, and Saddle Mountains Basalt (DOE 1988; Tolan et al. 1989) (Figure 10). The Saddle Mountains Basalt (the uppermost basalt at the Hanford Site) is divided into (from oldest to youngest) the Umatilla, Wilbur Creek, Asotin, Esquatzel, Pomona, Elephant Mountain, and Ice Harbor Members (Reidel and Fecht 1981).

4.1.1.2 Ellensburg Formation. The Ellensburg Formation consists of volcaniclastic and siliciclastic deposits that occur between CRBG basalt flows (DOE 1988; Smith 1988). At the Hanford Site the three uppermost units of the Ellensburg Formation are, from oldest to youngest, the Selah interbed, the Rattlesnake Ridge interbed, and the Levy interbed. A detailed discussion of the Ellensburg Formation at the Hanford Site is given in Reidel and Fecht (1981). Smith (1988) and Smith et al. (1989) discuss the Ellensburg Formation and correlative units throughout the region.

4.1.1.3 Suprabasalt Sediments. Discussions of various aspects of suprabasalt sediment geology are found in Myers et al. (1979); Tallman et al. (1979, 1981); PSPL (1982); Bjornstad (1984); Fecht et a1. (1987); DOE (1988); Baker et al. (1989); Smith et a1. (1989); Delaney et al. (1991); Lindsey (1991a, 1992); Lindsey et al. (1991); and Reidel et al. (1992). Delaney et al. (1991), Lindsey (1991a), and Reidel et al. (1992) provide the most recent synopsis of suprabasalt sediment geology for the Hanford Site. The following discussion is summarized from these recent reports. 
Figure 10. Generalized Stratigraphy of the Pasco Basin and Surrounding Area.

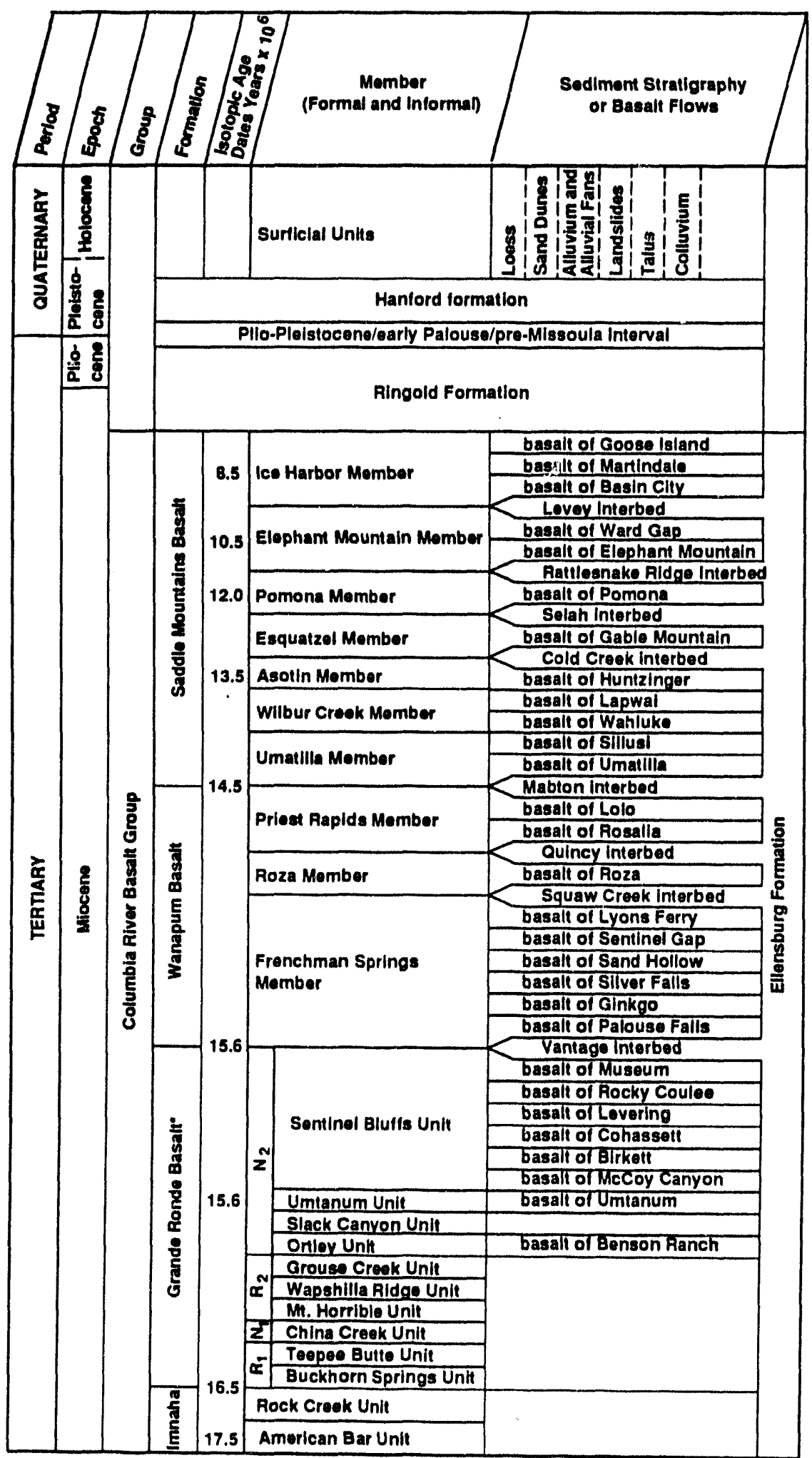

-The Grande Ronde Basalt consists of at least 120 major basall flows. Only a fow flows have been named. $N_{2}, R_{2}, N_{1}$ and $R_{1}$ are magnetostratlgraphic unils. 
The suprabasalt sedimentary sequence (Figure 11) is up to $229 \mathrm{~m}$ (750 ft) thick at the Hanford Site. It is dominated by the laterally extensive lateMiocene to Pliocene Ringold Formation and the Pleistocene Hanford formation. Laterally discontinuous units, referred to as the Plio-Pleistocene unit, early "Palouse" soil, and pre-Missoula gravels, separate the Hanford formation and Ringold Formation locally. Holocene-aged alluvial and eolian deposits cap the suprabasalt sequence.

4.1.1.3.1 Ringold Formation. The Ringold Formation is up to $183 \mathrm{~m}$ $(600 \mathrm{ft}$ ) thick within the Pasco Basin. The Ringold Formation pinches out against basalt ridges around the edge of and within the basin, and it consists of semi-indurated clay, silt, fine- to coarse-grained sand, and pebble to cobble grave1. Ringold deposits are grouped into five sediment facies associations (fluvial gravel, fluvial sand, overbank-paleosol, lacustrine, basaltic alluvium) that are defined on the basis of lithology, petrology, stratification, and pedogenic alteration. The associations are summarized as follows:

(1) Fluvial gravel--Consists of clast and lesser matrix-supported pebble to cobble gravel with a fine- to medium-grained sand matrix. Grainsize distributions tend to be bimodal with granules and coarsegrained sand being rare. Crude to well-defined stratification and low-angle, lenticular bedding geometries generally dominate.

(2) Fluvial sand--Fine- to coarse-grained quartzo-feldspathic sands displaying well-defined stratification dominate. Fining upwards packages less than one to several meters thick are common.

(3) Overbank-paleosol--Laminated to massive silty sand, silt, and clay displaying evidence of pedogenic alteration dominates.

(4) Lacustrine--Characterized by well-stratified clay with interbedded silt and silty sand.

(5) Basaltic alluvium--Massive to crudely stratified, weathered to unweathered, basaltic pebble to cobble gravel, commonly with a mudrich matrix dominates.

The distribution of facies associations within the Ringold Formation forms the basis for stratigraphic subdivision (Lindsey 199la, 1991b). The lower half of the Ringold Formation is characterized by fluvial gravel and sand-dominated intervals designated units $A, B, C, D$, and $E$ (Figure 12) that interfinger with fine-grained deposits typical of the overbank-paleosol and lacustrine facies associations. The lowest of these fine-grained intervals is designated the lower mud unit (see Figure 12). Interstratified deposits of the fluvial sand and overbank-paleosol facies associations and strata dominated by the lacustrine facies association form the upper half of the Ringold Formation (commonly referred to as the upper Ringold). 
Figure 11. Generalized Stratigraphy of the Suprabasalt Sediments in the Pasco Basin.

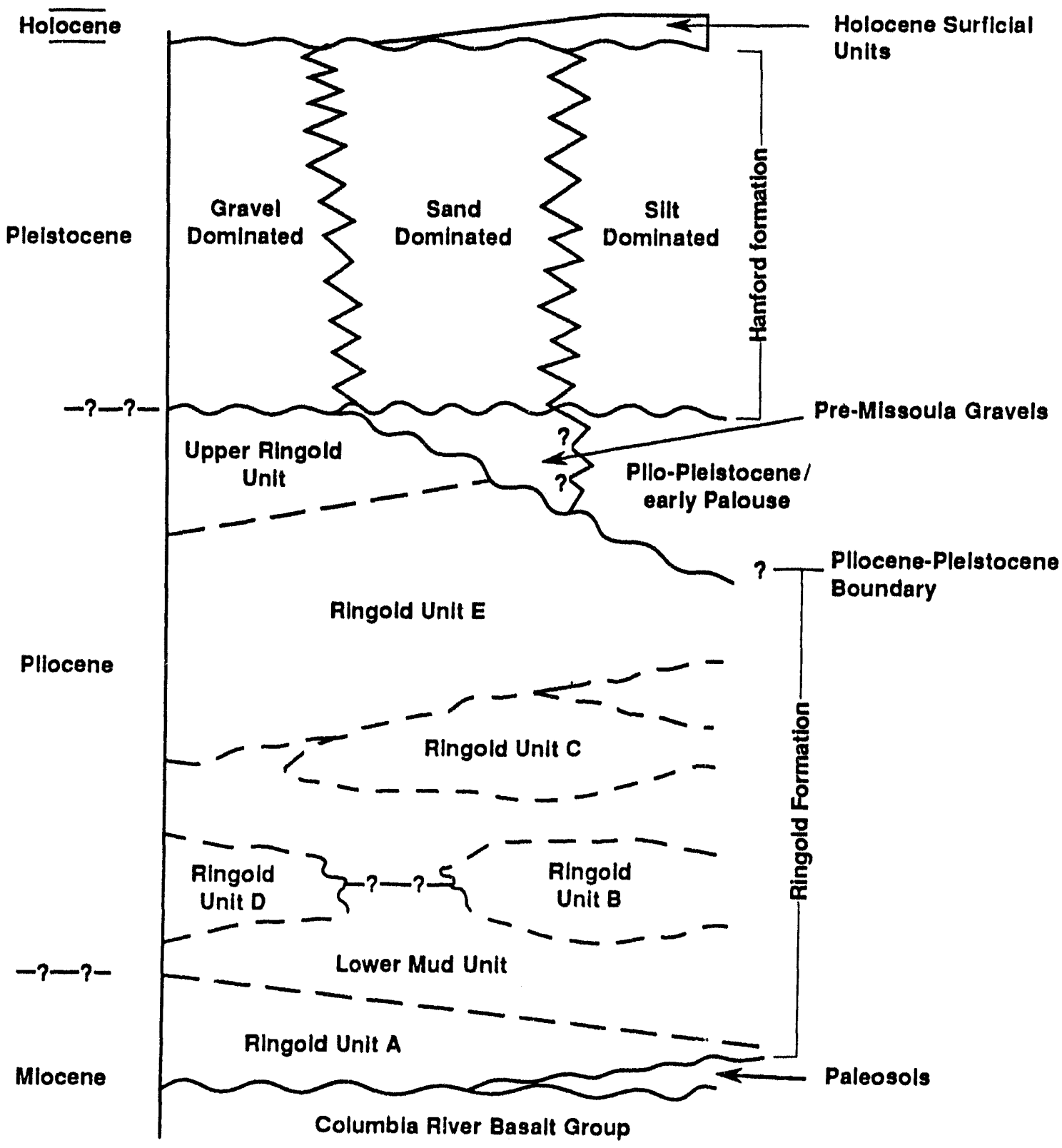

H9307034.3 
Figure 12. Generalized Stratigraphy of the Miocene-Pliocene Ringold Formation in the Pasco Basin. Figure Also Illustrates the Distribution of Major Sediment Facies in the Formation (Lindsey 1991a).

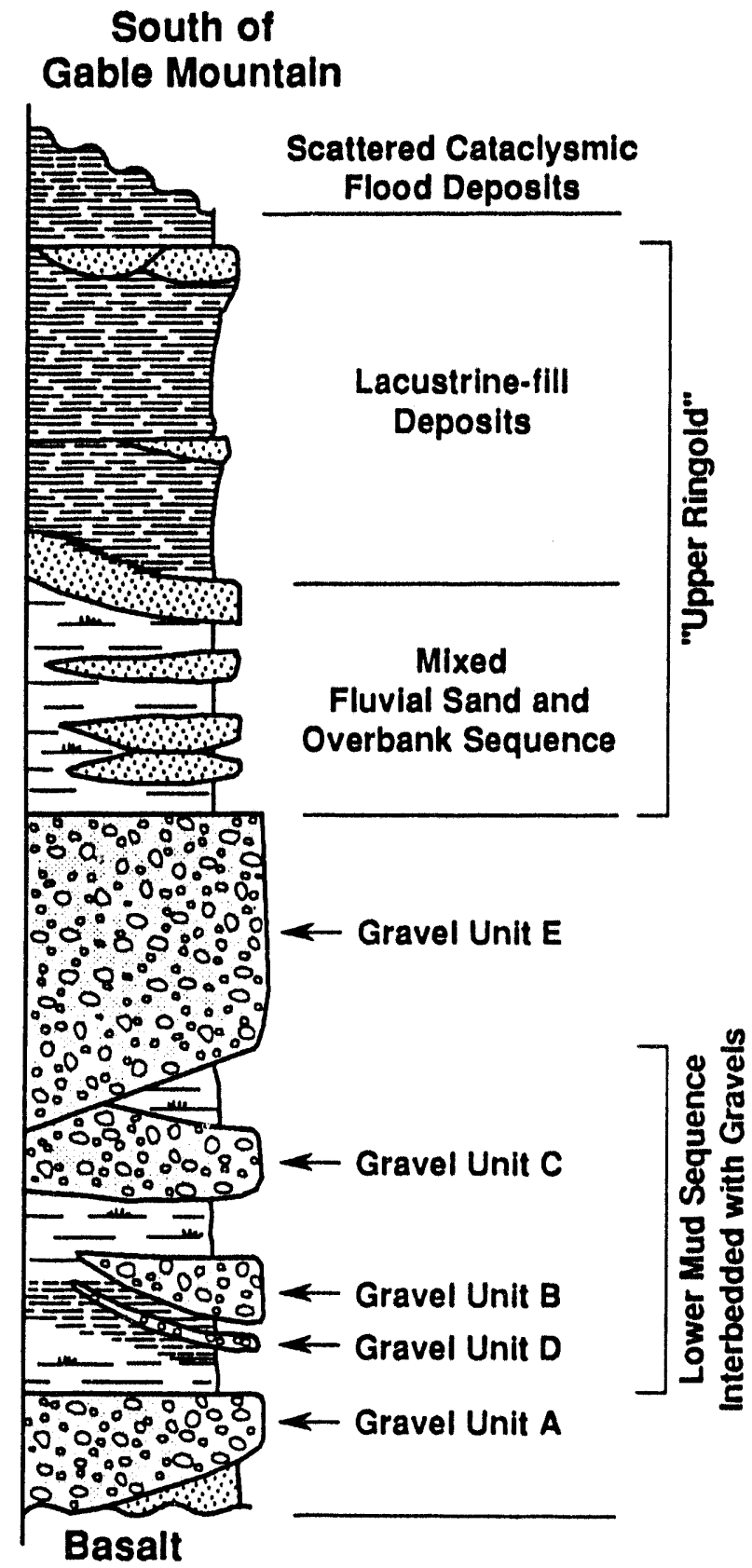

$\because 0 \%$ $\because 00$

Fluvial Gravel-dominated

Fluvial Sand-dominated

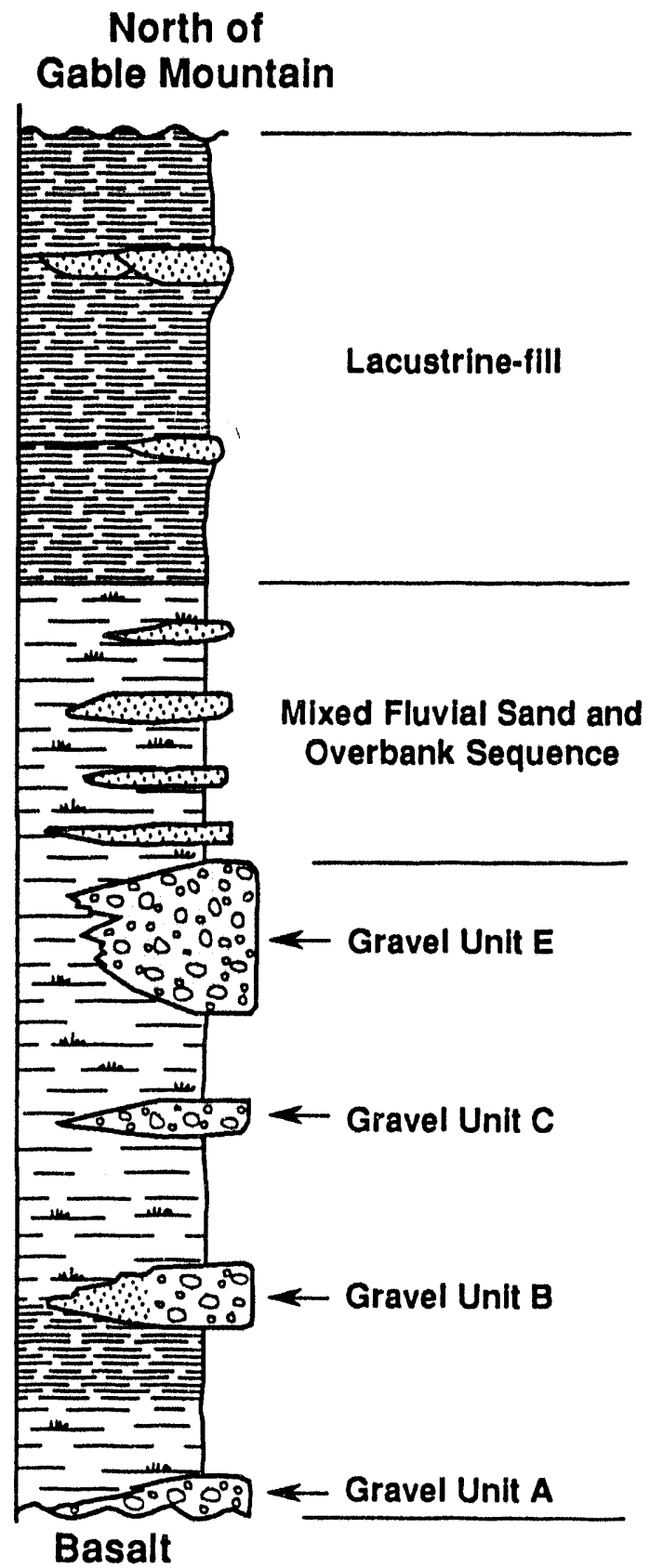

Overbank-dominated "mud" sequence Lacustrine-dominated 
Several localized, informal units separate the Ringold Formation from the Hanford formation. These units are the (1) Plio-Pleistocene unit, (2) pre-Missoula gravels, and (3) early "Palouse" soil (see Figure 12) (Myers et a1. 1979; Tallman et a1. 1979, 1981; DOE 1988; Reidel et a1. 1992). The PIio-Pleistocene unit and early "Palouse" soil consist of loess, pedogenic $\mathrm{CaCO}_{3}$, and basaltic sands and gravels. Uncemented mixed 1ithology gravels with a quartzo-feldspathic matrix dominate the pre-Missoula gravels.

4.1.1.3.2 Hanford Formation. The Hanford formation consists of uncemented gravel, sand, and silt deposited by Pleistocene cataclysmic flood waters (Fecht et al. 1987; DOE 1988; Baker et al. 1989). The Hanford formation is thickest in the vicinity of the 200 West and 200 East Areas where it can be up to $107 \mathrm{~m}(350 \mathrm{ft})$ thick. The Hanford formation is divided into three facies (gravel, sand, and silt dominated) that are gradational with each other. The facies are summarized as follows:

(1) Gravel-dominated facies--Generally consists of cross-stratified, coarse-grained sand and granule to boulder gravel that contain minor intercalated silt-rich horizons. These gravels generally are uncemented and matrix poor, displaying an open-framework texture.

(2) Sand-dominated facies--Well-stratified, fine- to coarse-grained sand and granule gravel dominate. Silt content is variable, but where it is low an open-framework texture is common. Small pebbles and ripup clasts in addition to lenticular, pebble-gravel interbeds and silty interbeds may be present.

(3) Silt-dominated facies--Interbedded silt and fine- to coarse-grained sand forming well-stratified normally graded rhythmites are characteristic.

In addition to the three facies, clastic dikes also are commonly found in the Hanford formation as well as locally in other sedimentary units in the Pasco Basin (Black 1979). These clastic dikes are structures that generally cross-cut bedding, although they do locally parallel bedding. The dikes usually consist of thin, alternating vertical to subvertical layers of silt, sand, and granules. Where the dikes intersect the ground surface, a feature known as "patterned ground" can be observed.

4.1.1.4 Holocene Surficial Deposits. Holocene surficial deposits consist of silt, sand, and gravel that form a thin (4.9 $\mathrm{m}[<16 \mathrm{ft}])$ veneer across much of the Hanford Site. These sediments were deposited by a mix of eolian and alluvial processes.

4.1.1.5 Structural Geology. The Columbia Plateau is divided into three informal structural subprovinces: Blue Mountains, Palouse, and the Yakima Fold Belt (Reidel et al. 1989; Tol an and Reidel 1989). These structural subprovinces are delineated on the basis of their structural fabric. The Hanford Site is located in the eastern Yakima Fold Belt near its junction with the Palouse subprovince.

The Yakima Fold Belt consists of a series of segmented, narrow, asymmetric, and generally east-west trending anticlines that separate broad, low-amplitude structural basins (Reidel 1984, Reidel et al. 1989). The Pasco Basin (where the Hanford Site is situated) is one of the largest structural 
WHC-EP-0675

basins within the Yakima Fold Belt. The Pasco Basin is bounded on the north by the Saddle Mountains anticline, on the west by the Hog Ranch-Naneum Ridge anticline, and on the south by the Rattlesnake Mountain anticline. The Palouse slope, a west-dipping monocline, bounds the Pasco Basin on the east. The Pasco Basin is divided into the Wahluke and Cold Creek synclines by the Gable Mountain anticline, the easternmost extension of the Umtanum Ridge anticline.

\subsubsection{0-N Area Geology}

The 100-N Area geology summarized in this section is drawn primarily from work done by Hartman (1993) on the RCRA Program for the 100-N Area. Most of the boreholes in the 100-N Area penetrate less than the upper $30 \mathrm{~m}(100 \mathrm{ft})$ of the stratigraphic section. Five boreholes near the $100-N$ Area penetrate the entire suprabasalt sediment sequence (Figure 13). One of these boreholes, 699-86-60, was drilled using a cable-tool rig; the driller's log is complete to the top of the CRBG. The other four deep boreholes were drilled by the Washington Public Power Supply System and are documented in WPPSS (1974). Three of the boreholes, 699-84-59 (called BH-16 in the WPPSS report), 699-81-62 (BH-17), and 699-86-64 (BH-18) were cored through the suprabasalt sequence and into the Asot in Member of the Saddle Mountains Basalt. The other deep borehole, 699-84-62A (BH-1), is a rotary-drilled hole to the top of basalt.

Figure 14 is a generalized stratigraphic column for the 100-N Area, which shows the units that are present in the area, approximate unit thicknesses, and the location of the water table.

Figure 15 shows the line of cross sections drawn west-east (Figure 16) and north-south (Figure 17) through the 100-N Area. These cross sections help to fllustrate the stratigraphic location and areal distribution of units discussed in subsequent sections.

4.1.2.1 Columbia River Basalt Group. The cored boreholes that penetrate the CRBG near the 100-N Area encountered the following members of the Saddle Mountains Basalt: the Elephant Mountain Member, the Pomona Member, the Wilbur Creek Member, and the Asot in Member. The entire basalt stratigraphy of the area is interpreted from a borehole east of the site and another borehole north of the site in the Saddle Mountains. Columbia River basalts are estimated to be more than $3,658 \mathrm{~m}(12,000 \mathrm{ft})$ thick beneath the $100-\mathrm{N}$ Area (Reidel and Hooper 1989).

The 100-N Area lies above a buried course of the ancestral ClearwaterSnake River, that existed during the Saddle Mountain time (Reidel and Fecht 1981). This channel developed along flow margins that controlled the river channel and the path of several basalt flows as well. 
Figure 13. Locations of Washington Public Power Supply System Boreholes Near the 100-N Area (Hartman 1993).

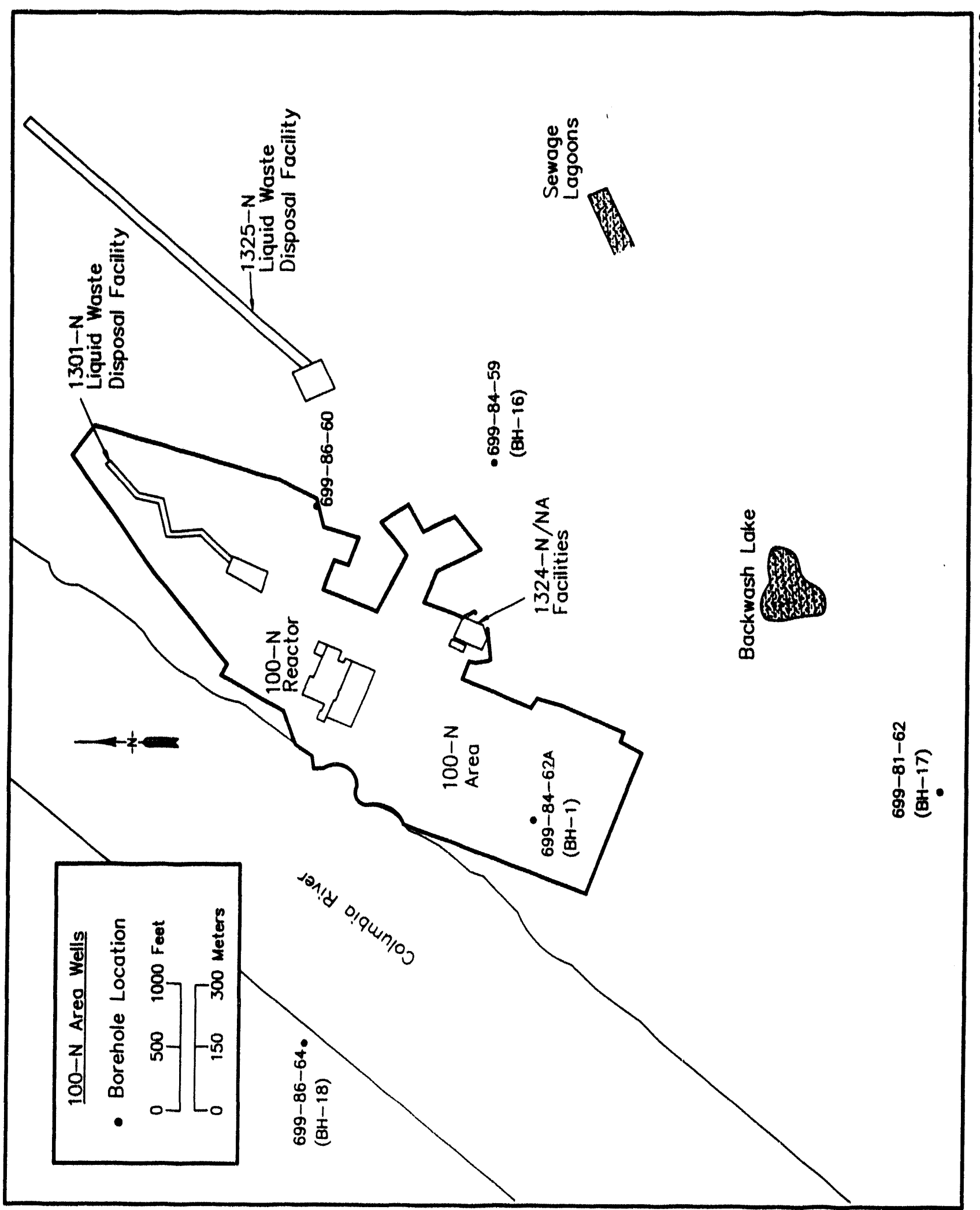


Figure 14. Generalized Stratigraphic Column for the 100-N Area.

\section{5-N Area General Geology}

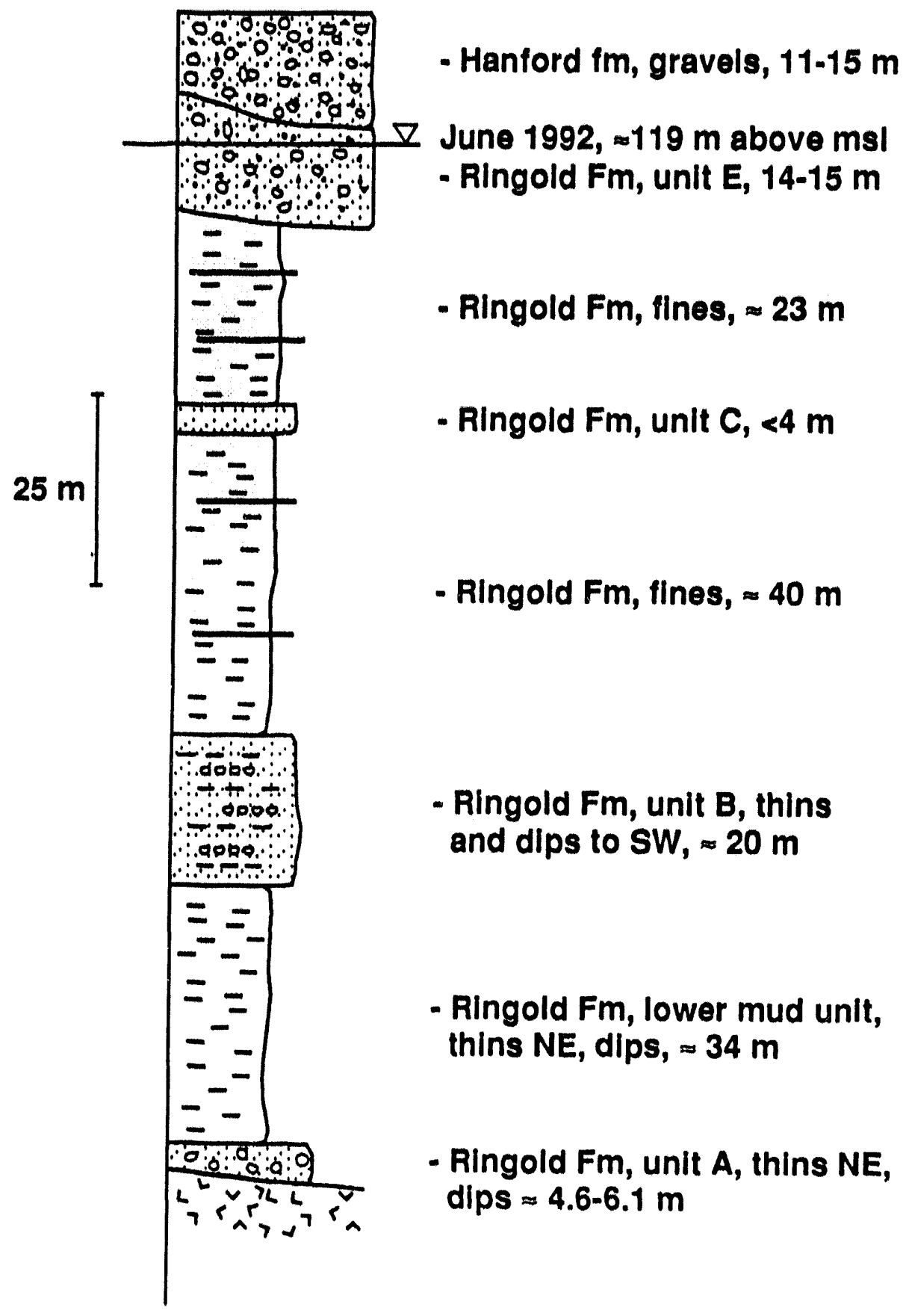


WHC-EP-0675

Figure 15. Line of Cross Sections Drawn West-East and North-South Through the 100-N and Surrounding Area.

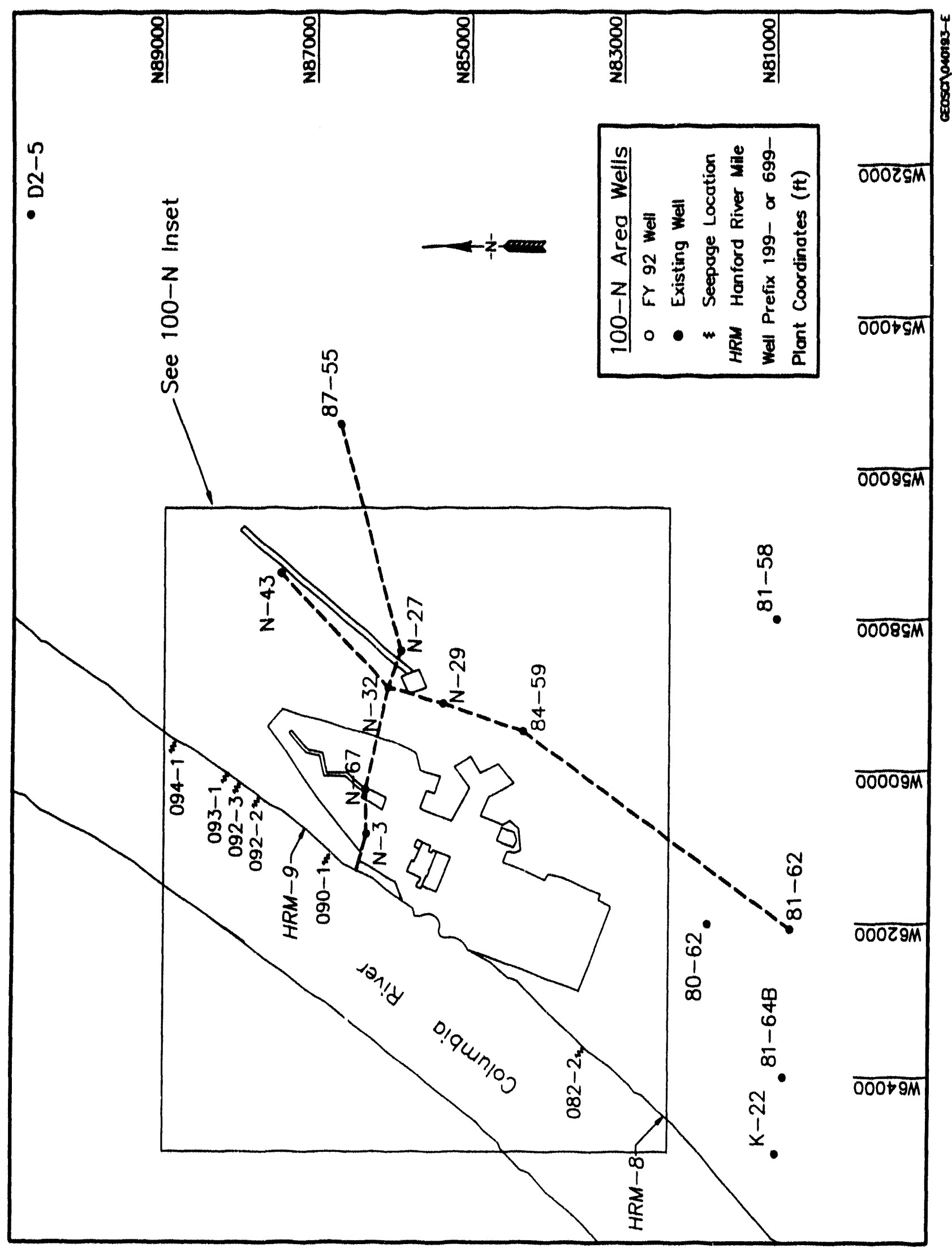




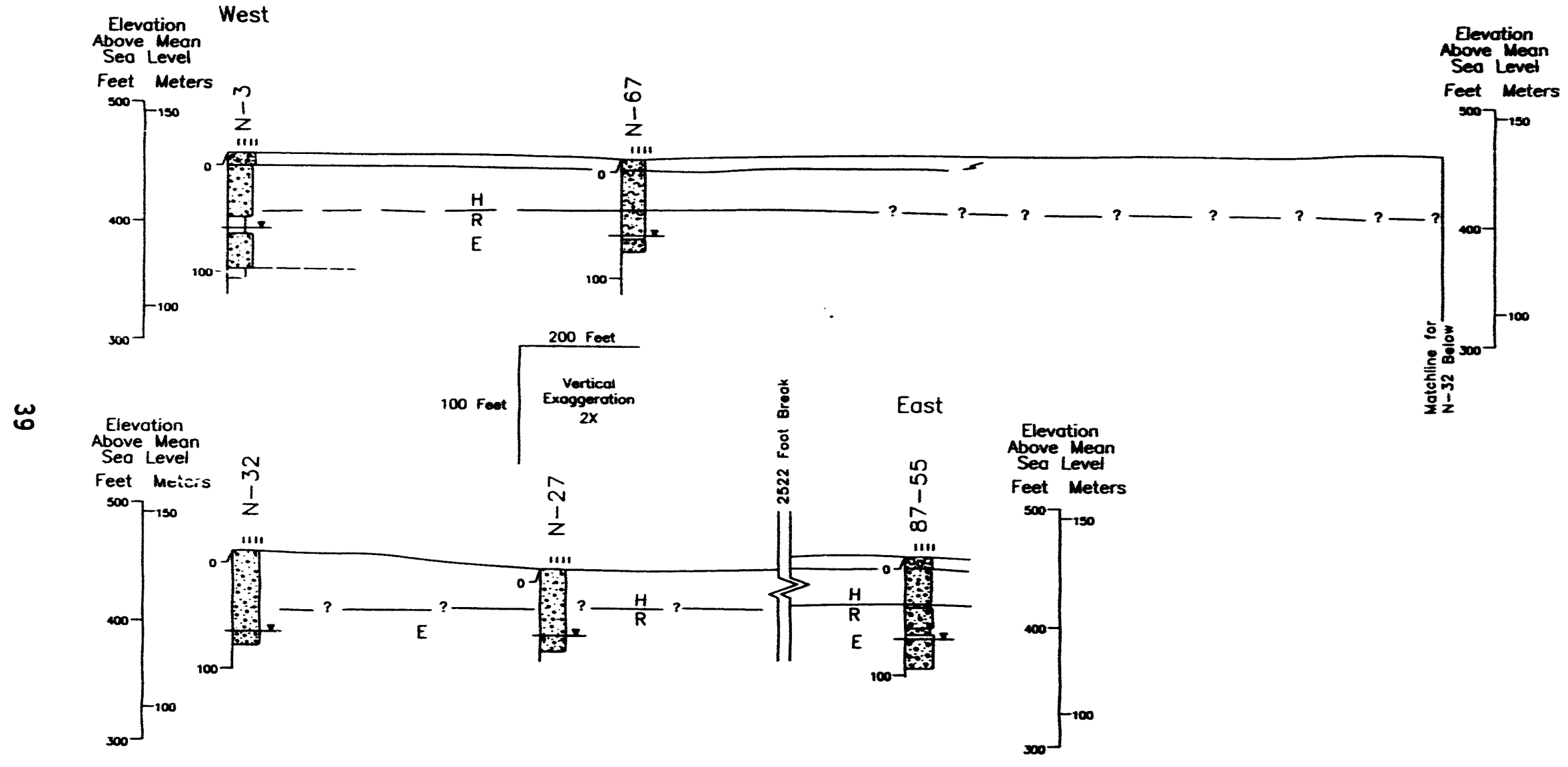

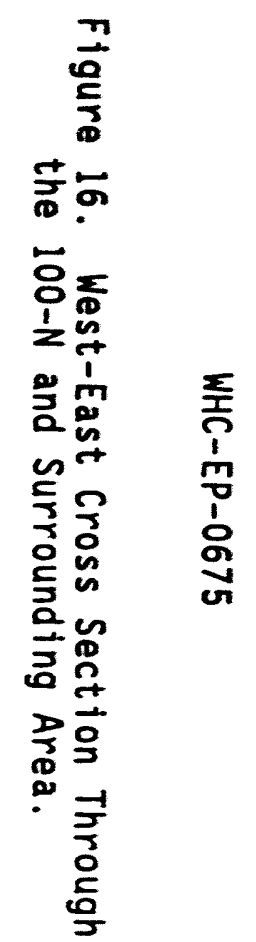

Kullasooesci 


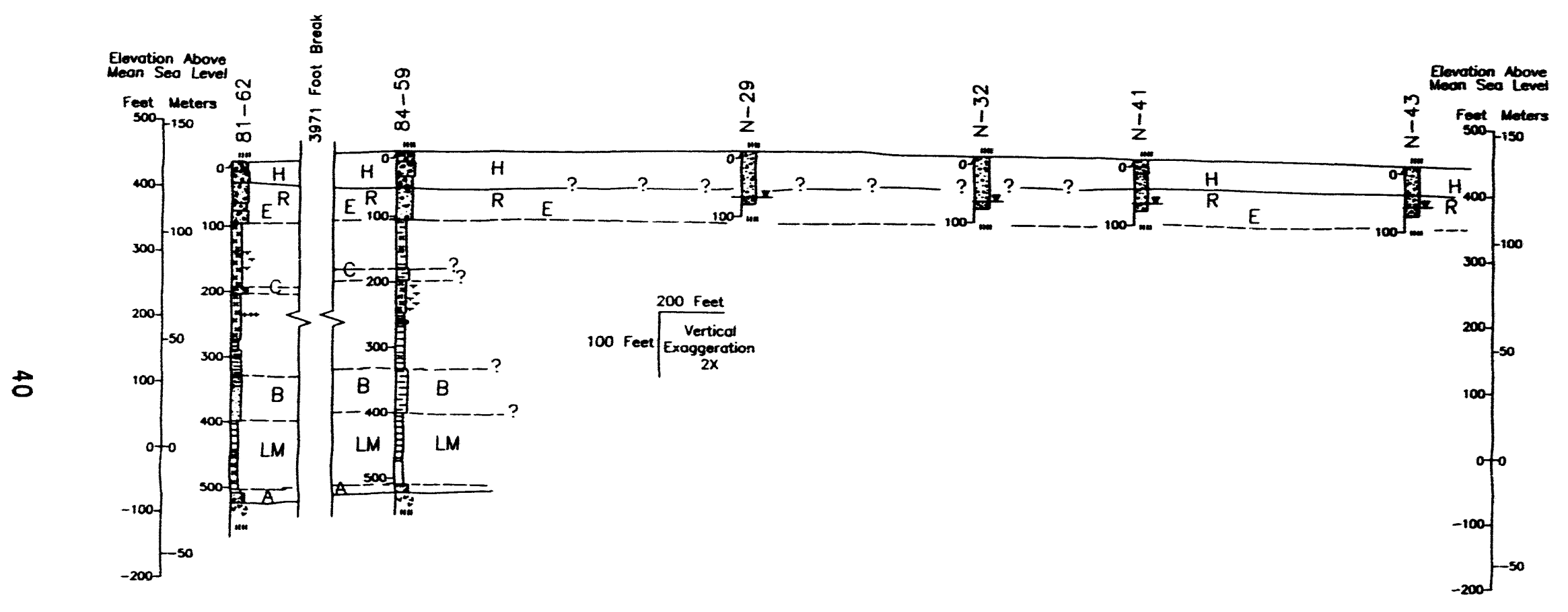

KN</050993:1

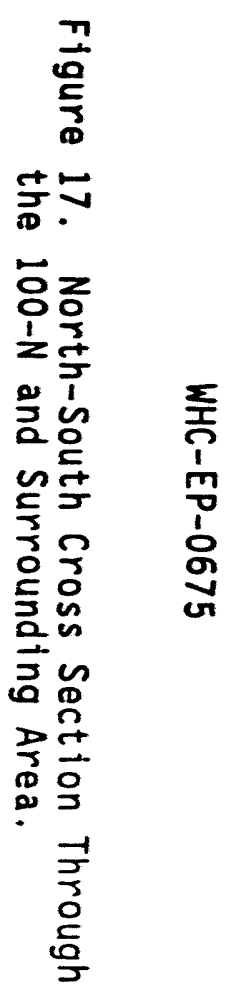


4.1.2.2 Ellensburg Formation. Very little is known about the nature of the Ellensburg Formation in the 100-N Area. Three cored boreholes near the 100-N Area that penetrate the formation indicate the principal lithologies are sandstones, siltstones, and claystones, with minor conglomerates throughout the section. The lithologies probably represent channel and overbank deposits related to the ancestral Clearwater-Snake River system. The uppermost unit of the formation at the 100-N Area is the Rattlesnake Ridge interbed.

\subsubsection{Suprabasalt Sediments.}

4.1.2.3.1 Ringold Formation. The fluvial-lacustrine Ringold Formation was deposited in basins and generally east-west trending valleys by the ancestral Columbia River and its tributaries in response to development of the Yakima Fold Belt. Although exposures of the Ringold Formation are limited to the White Bluffs east of the 100-N Area and to the Smyrna and Taunton Benches north of the Saddle Mountains, data on the formation are available from the three cored boreholes and two rotary boreholes near the 100-N Area (see Figure 13).

The Ringold stratigraphy is best described in the 100-N Area in terms of facies type. At the 100-N Area, the formation consists predominantly of interstratified clays, silts, sands, and paleosols. Thin gravels occur near the top and bottom of the Ringold section.

A cross section through the 100 Areas (Figure 18), developed from the three cored and two rotary boreholes, shows the distribution of sediment types in the subsurface. The Ringold Formation is approximately $137 \mathrm{~m}(450 \mathrm{ft})$ thick at the 100-N Area, but thins to $129 \mathrm{~m}$ (422 ft) across the Columbia River to the west (at borehole 699-86-64). This may reflect erosion caused by the Columbia River, perhaps before the Pleistocene catastrophic flooding.

The contact between the Ringold Formation and the overlying Hanford formation in the 100-N Area is best distinguished using the compositional differences in the sands and gravels of the two units. The Ringold Formation is dominated by quartzo-feldspathic materials and the Hanford formation is dominated by basaltic material. In the field, this is best recognized as a color change; the Hanford formation is black or grey, and the Ringold Formation is tan or brown.

4.1.2.3.2 Hanford Formation. The Hanford formation represents proglacial flood deposits, primarily from the late-Pleistocene. Alluvial deposits include river deposits, landslides, and windblown loess and sand.

In the 100-N Area the Hanford formation consists of sands and gravels. There appears to be a general coarsening downward, but no detailed work has been done in the area on this topic. The unit is approximately 12 to $18 \mathrm{~m}$ (40 to $60 \mathrm{ft}$ ) thick. The elevation of the Hanford-Ringold contact, and where known the base of the uppermost aquifer, are given in Table 5 . 


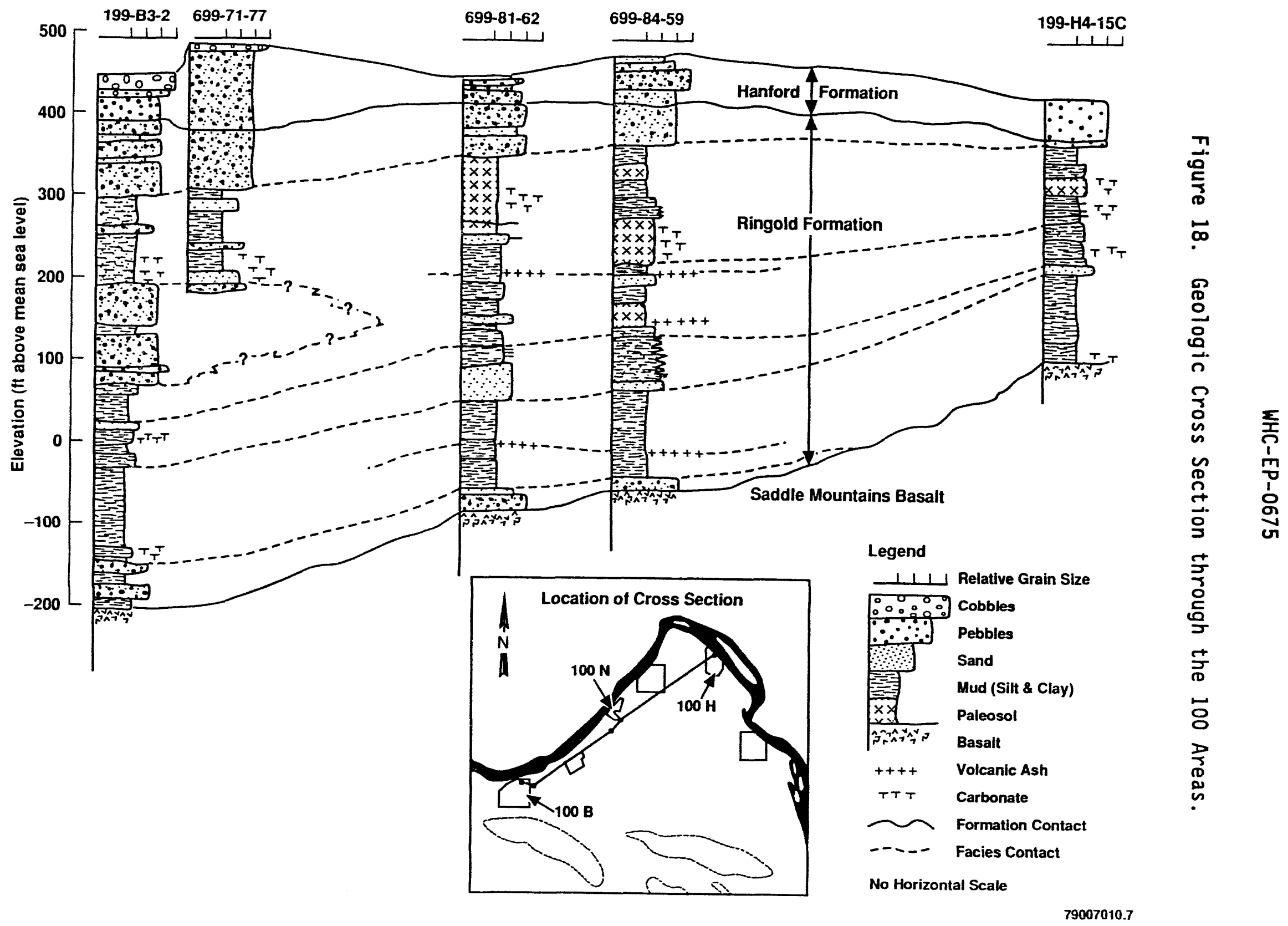


Table 5. Elevation of Geologic Units at 100-N Area Resource Conservation and Recovery Act of 1976 Sites (Hartman 1993).

\begin{tabular}{|c|c|c|c|}
\hline Site & $\begin{array}{l}\text { Elevation of } \\
\text { surface }-\mathrm{m} \mathrm{ms} 1 \\
(\mathrm{ft} \mathrm{ms} 1)\end{array}$ & $\begin{array}{c}\text { Elevation of } \\
\text { Hanford/Ringold } \\
\text { contact }-\mathrm{m} \text { msl } \\
(\mathrm{ft} \mathrm{ms})\end{array}$ & $\begin{array}{l}\text { Elevation top of } \\
\text { fine-grained unit - } \\
\mathrm{m} \mathrm{ms} 1 \text { and ( } \mathrm{ft} \mathrm{msl}) \\
\text { [no. of wells] }\end{array}$ \\
\hline $1301-N$ & $\begin{array}{l}137 \text { to } 140 \\
(450 \text { to } 460)\end{array}$ & $\begin{array}{l}120 \text { to } 127 \\
(394 \text { to } 417)\end{array}$ & $\begin{array}{c}107 \text { to } 110 \\
(350 \text { to } 360[4])\end{array}$ \\
\hline $1325-N$ & $\begin{array}{l}137 \text { to } 140 \\
(450 \text { to } 460)\end{array}$ & $\begin{array}{l}124 \text { to } 126 \\
(406 \text { to } 415)\end{array}$ & $\begin{array}{c}107 \\
(350[1])\end{array}$ \\
\hline
\end{tabular}

ms1 = mean sea level.

4.1.2.4 Holocene Surficial Deposits. Holocene deposits in the vicinity of the 100-N Area consist of Columbia River overbank sediments and minor amounts of eolian silt and sand.

\subsubsection{Regional and Hanford Site Hydrology}

4.1.3.1 Surface Water. Surface drainage enters the Pasco Basin from several other basins, which include the Yakima River Basin, Horse Heaven Basin, Walla Walla River Basin, Palouse/Snake Basin, and Big Bend Basin (Figure 19) (DOE 1988). Within the Pasco Basin, the Columbia River is joined by major tributaries including the Yakima, Snake, and Walla Walla Rivers. No perennial streams originate within the Pasco Basin. Columbia River inflow to the Pasco Basin is recorded at the United States Geological Survey gage below Priest Rapids Dam, and outflow is recorded below McNary Dam. Average annual flow at these recording stations is approximately $1.1 \times 10^{11} \mathrm{~m}^{3}\left(8.7 \times 10^{7}\right.$ acre-ft) at the United States Geological Survey gage and $1.6 \times 10^{11} \mathrm{~m}^{3}\left(1.3 \times 10^{8} \mathrm{acre}-\mathrm{ft}\right)$ at the McNary Dam gage (DOE 1988).

Total estimated precipitation over the basin averages less than $15.8 \mathrm{~cm} / \mathrm{yr}(6.2 \mathrm{in}, \mathrm{yr})$. Mean annual runoff from the basin is estimated to be less than $3.1 \times 10^{7} \mathrm{~m}^{3} / \mathrm{yr}\left(1.1 \times 10^{9} \mathrm{ft}^{3} / \mathrm{yr}\right)$, or approximately $3 \%$ of the total precipitation. The remaining precipitation is assumed to be lost through evapotranspiration with a smal1 component (perhaps less than 1\%) recharging the groundwater system (DOE 1988).

Primary surface water features associated with the Hanford Site are the Columbia River and the Yakima River. West Lake, about $40,470 \mathrm{~m}^{2}$ (10 acres) in size and less than $1 \mathrm{~m}(3 \mathrm{ft})$ deep, is the only natural lake within the Hanford Site (DOE 1988). Wastewater ponds, cribs, and ditches associated with nuclear fuel processing and waste disposal activities also are present on the Hanford Site (Figure 20). 


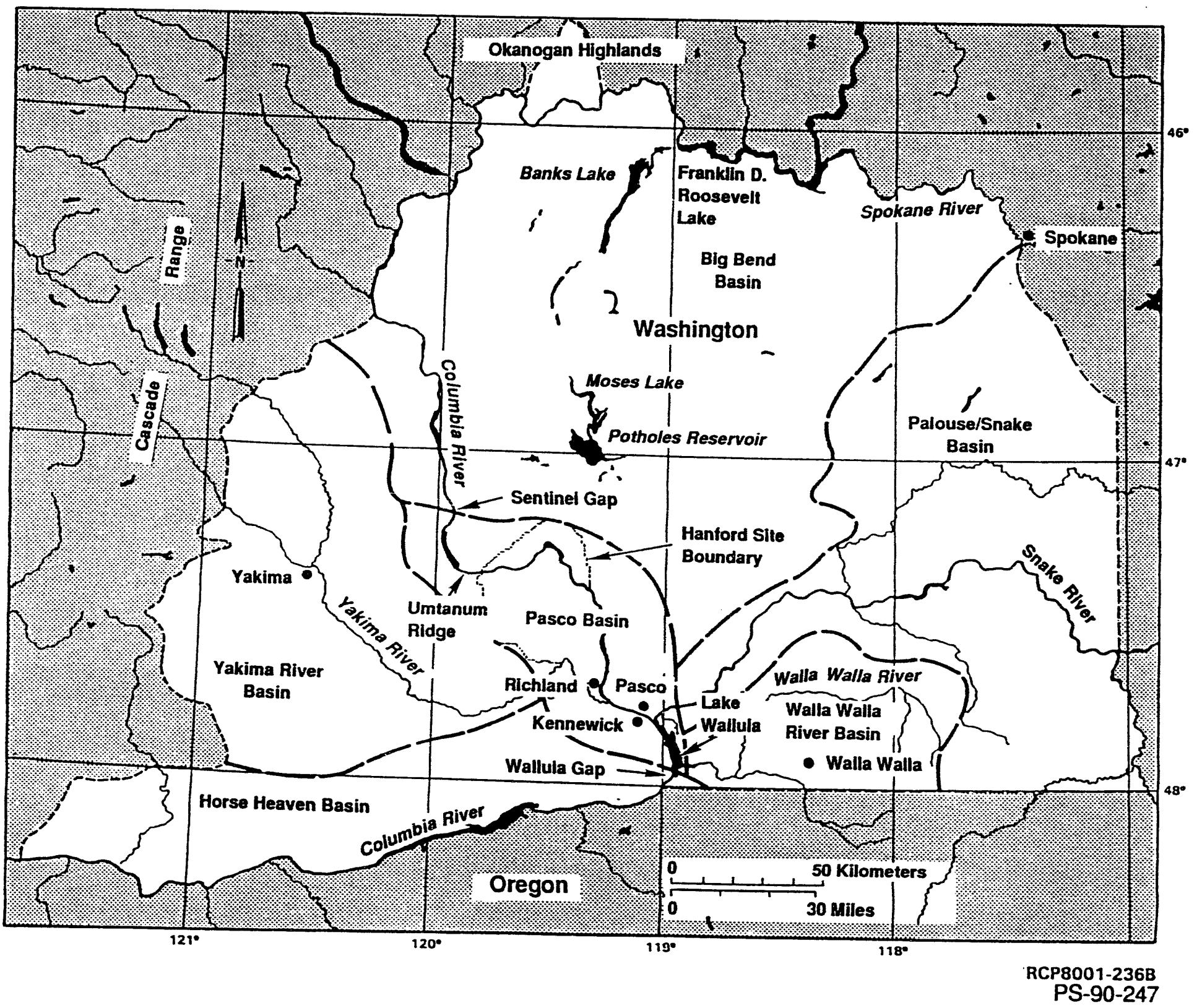

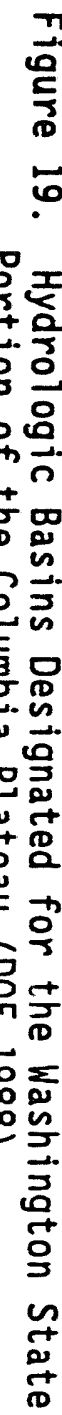


Figure 20. Location of Major Liquid Effluent Disposal Sites on the Hanford Site.

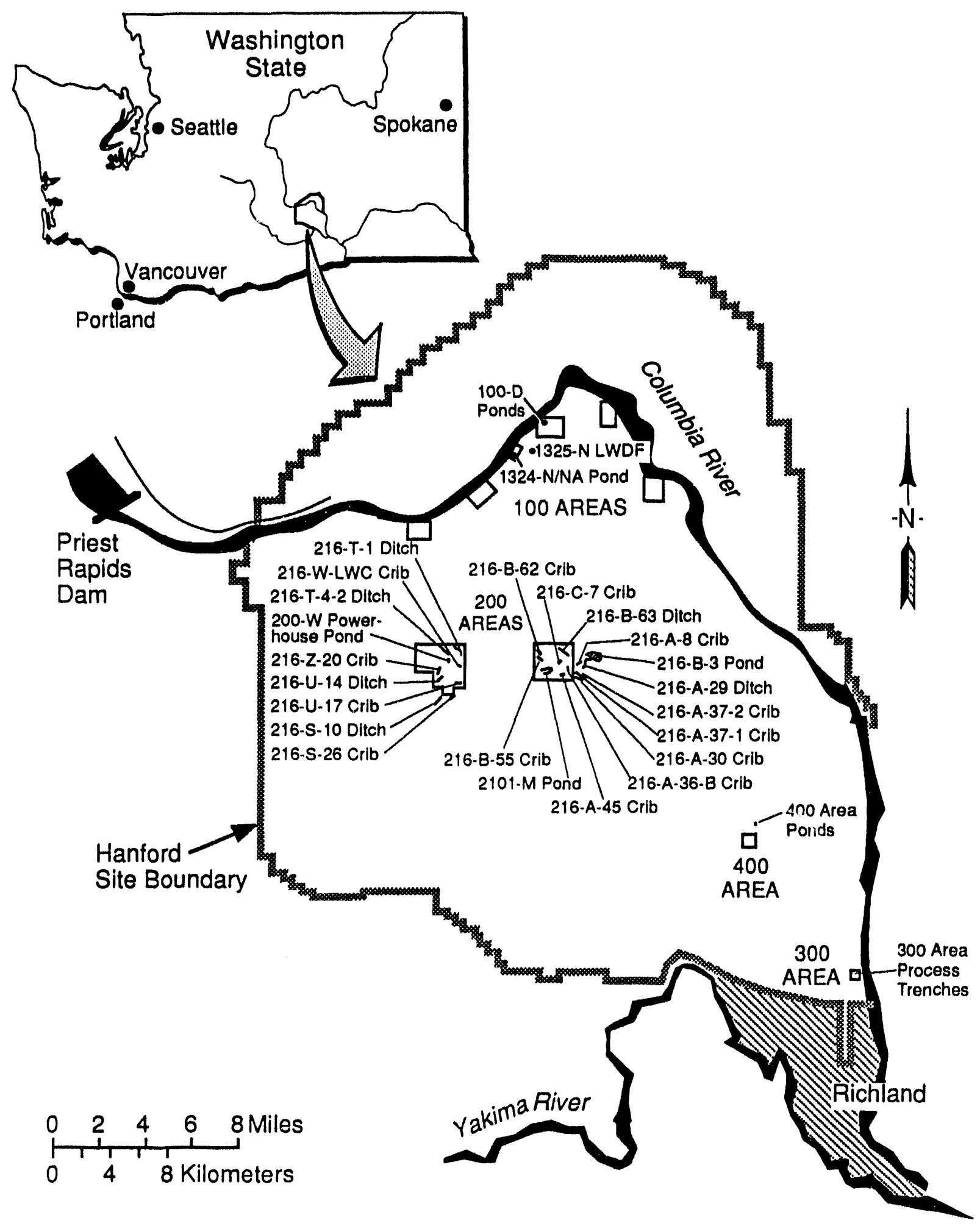

S9007025.C 
The Columbia River flows through the northern part and along the eastern border of the Hanford Site. This section of river, the Hanford Reach, extends from Priest Rapids Dam to the headwaters of Lake Wallula (the reservoir behind McNary Dam). Flow along the Hanford Reach is controlled by the Priest Rapids Dam. Several drains and intakes also are present along the Hanford Reach, including irrigation outfalls from the Columbia Basin Irrigation Project, the Washington Pubiic Power Supply System Nuclear Project 2 intakes, and Hanford Site intakes for onsite water use.

Routine water quality monitoring of the Columbia River is conducted by the DOE for both radiological and nonradiological parameters and has been reported by the Pacific Northwest Laboratory since 1973. Ecology has issued a Class $A$ (excellent) quality designation for Columbia River water along the Hanford Reach from Grand Coulee Dam, through the Pasco Basin, to McNary Dam. This designation requires that all industrial uses of this water be compatible with other uses, including drinking, wildlife habitat, and recreation. In general, the Columbia River water is characterized by a very low suspended load, a low nutrient content, and an absence of microbial contaminants (DOE 1988).

Approximately one-third of the Hanford Site is drained by the Yakima River system. Cold Creek and its tributary, Dry Creek, are ephemeral streams within the Yakima River drainage system. Both streams drain areas along the western part of the Hanford Site and cross the southwestern part of the Hanford Site toward the Yakima River. Surface flow, which may occur during spring runoff or after heavier-than-normal precipitation, infiltrates and disappears into the surface sediments. Rattlesnake Springs, located on the western part of the Hanford Site, forms a small surface stream that flows for about $2.9 \mathrm{~km}$ (1.8 $\mathrm{mi}$ ) before infiltrating into the ground.

\subsubsection{Groundwater. Information in this section is summarized from} Delaney et a1. (1991). The hydrogeology of the Pasco Basin is characterized by a multiaquifer system that consists of four hydrogeologic units that correspond to the upper three formations of the CRBG (Grande Ronde Basait, Wanapum Basalt, and Saddle Mountains Basalt) and the suprabasalt sediments. The basalt aquifers consist of the tholeiitic flood basalts of the CRBG and relatively minor amounts of intercalated fluvial and volcaniclastic sediments of the Ellensburg Formation. Confined zones in the basalt aquifers are present in the sedimentary interbeds and/or interflow zones that occur between dense basalt flows. The main water-bearing portions of the interflow zones are networks of interconnecting vesicles and fractures of the flow tops and bottoms (DOE 1988). The suprabasalt sediment or uppermost aquifer system consists of fluvial, lacustrine, and glaciofluvial sediments. Regionally, this aquifer is unconfined and is contained largely within the Ringold Formation and Hanford formation. Table 6 presents hydraulic parameters for various water-bearing geologic units at the Hanford Site.

Local recharge to the shallow basalt aquifers results from infiltration of precipitation and runoff along the margins of the Pasco Basin and in areas of artificial recharge where a downward gradient from the unconfined aquifer system to the uppermost confined basalt aquifer may occur. Regional recharge of the deep basalt aquifers is inferred to result from interbasin groundwater movement originating northeast and northwest of the Pasco Basin in areas where the Wanapum and Grande Ronde Basalts crop out extensively (DOE 1988). 
Table 6. Hydraulic Parameters for Various Areas at the Hanford Site (Delaney et al. 1991).

\begin{tabular}{|c|c|c|c|c|c|}
\hline Location & Interval tested & $\begin{array}{c}\text { Hydraulic } \\
\text { conductivity } \mathrm{m} / \mathrm{d} \\
\text { (ft/d) }\end{array}$ & $\begin{array}{l}\text { Transmissivity } \\
\mathrm{m}^{2} / \mathrm{d}\left(\mathrm{ft}^{2} / \mathrm{d}\right)\end{array}$ & $\begin{array}{l}\text { Effective } \\
\text { porosity }\end{array}$ & Data source \\
\hline 100 Areas & $\begin{array}{l}\text { Rattlesnake } \\
\text { Ridge interbed }\end{array}$ & $(0$ to 100$)$ & -- & $<10 \%$ & $\begin{array}{l}\text { Gephart et } \\
\text { al. (1979) }\end{array}$ \\
\hline Hanford Site & $\begin{array}{l}\text { Saddle Mountain } \\
\text { Basalt Flowtop } \\
\end{array}$ & $\left(10^{-2}\right.$ to $\left.10^{-6}\right)$ & - & $5 \%$ & $\begin{array}{l}\text { Cushing } \\
(1989)\end{array}$ \\
\hline 100 Areas & $\begin{array}{l}\text { Ringold } \\
\text { Formation Unit } E\end{array}$ & (29 to 1,297$)$ & $\begin{array}{l}(5,750 \text { to } \\
26,700)\end{array}$ & -- & $\begin{array}{l}\text { Liikala et } \\
\text { al. (1988) }\end{array}$ \\
\hline 200 Areas & $\begin{array}{l}\text { Rattlesnake } \\
\text { Ridge interbed }\end{array}$ & -- & (8 to 1,165$)$ & - & $\begin{array}{l}\text { Graham et ai. } \\
(1984)\end{array}$ \\
\hline $\begin{array}{l}200 \text { East } \\
\text { Area }\end{array}$ & $\begin{array}{l}\text { Elephant } \\
\text { Mountain } \\
\text { Interflow Zone }\end{array}$ & - & $(7.5$ to 6,120$)$ & & $\begin{array}{l}\text { Graham et al. } \\
(1984)\end{array}$ \\
\hline Hanford Site & Selah interbed & -- & $\left(3 \times 10^{-5}\right)$ & - & $\begin{array}{l}\text { Graham et al. } \\
\text { (1984) }\end{array}$ \\
\hline $\begin{array}{c}200 \text { West } \\
\text { Area }\end{array}$ & $\begin{array}{l}\text { Ringold } \\
\text { Formation Unit } E\end{array}$ & $(0.6$ to 200$)$ & - & -- & $\begin{array}{l}\text { Last et al. } \\
(1989)\end{array}$ \\
\hline 1100 Area & $\begin{array}{l}\text { Ringold } \\
\text { Formation Units } \\
\text { C/B }\end{array}$ & $\left(3 \times 10^{-1}\right.$ to 5$)$ & -- & -- & $\begin{array}{l}\text { Lindberg and } \\
\text { Bond (1979) }\end{array}$ \\
\hline 1100 Area & $\begin{array}{l}\text { Ringold } \\
\text { formation } \\
\text { overbank } \\
\text { Deposits } \\
\end{array}$ & $\left(8 \times 10^{-4}\right.$ to & - & -- & $\begin{array}{l}\text { Lindberg and } \\
\text { Bond (1979) }\end{array}$ \\
\hline 300 Area & Levey interbed & $(0.01$ to 1,000$)$ & - & -- & $\begin{array}{l}\text { DOE-RL } \\
(1990)\end{array}$ \\
\hline 300 Area & $\begin{array}{l}\text { Ringold } \\
\text { Formation }\end{array}$ & $(1.9$ to 10,000$)$ & -- & -- & $\begin{array}{l}\text { DOE-RL } \\
(1990) \\
\end{array}$ \\
\hline 300 Area & $\begin{array}{l}\text { Hanford } \\
\text { formation }\end{array}$ & $\begin{array}{c}(11,000 \text { to } \\
50,000)\end{array}$ & -- & -- & $\begin{array}{l}\text { DOE-RL } \\
(1990)\end{array}$ \\
\hline
\end{tabular}


Groundwater discharge from shallow basalt aquifers is probably to the overlying aquifers and to the Columbia River. The discharge area(s) for the deeper groundwater system is (are) uncertain, but flow is inferred to be generaliy southeastward, with discharge to the south of the Hanford Site (DOE 1988).

Erosional "windows" through dense basalt flow interfors allow direct interconnection between the uppermost aquifer system and underlying confined basalt aquifers. Graham et a1. (1984) reported that some contamination was present in the uppermost confined aquifer (Rattlesnake Ridge interbed) south and east of Gable Mountain Pond. Graham et a1. (1984) evaluated the hydrologic relationships between the Rattlesnake Ridge interbed aquifer and the unconfined aquifer in this area, and delineated a potential area of intercommunication beneath the northeast portion of the 200 East Area.

The uppermost aquifer system is regionally unconfined beneath the

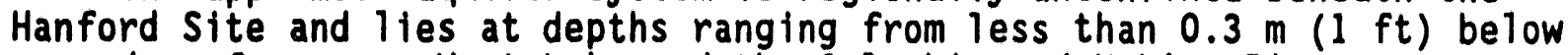
ground surface near West Lake and the Columbia and Yakima Rivers, to greater than $107 \mathrm{~m}(350 \mathrm{ft})$ in the central portion of the Cold Creek syncline. Groundwater in this aquifer system occurs within the glaciofluvial sands and gravels of the Hanford formation and the fluvial/lacustrine sediments of the Ringold Formation. Ringold sediments are divided into five lithofacies:

(1) fluvial gravel, (2) fluvial sand, (3) overbank deposits consisting of silt and sand, (4) lacustrine deposits, and (5) basaltic debris flow gravel (see Figure 12).

The position of the water table in the southwestern Pasco Bas in is generally within Ringold fluvial gravels of unit $E$. In the northern and eastern Pasco Basin the water table generally is within the Hanford formation. Hydraulic conductivities for the Hanford formation $(610$ to $3,048 \mathrm{~m} /$ day $[2,000$ to $10,000 \mathrm{ft} /$ day $]$ ) are much greater than those of the gravel facies of the Ringold Formation ( 186 to $930 \mathrm{~m} /$ day [610 to $3,050 \mathrm{ft} /$ day]) (Graham et al. 1981). The main body of the unconfined aquifer generally occurs within the Ringold Formation.

The base of the uppermost aquifer system is defined as the top of the uppermost basalt flow. However, fine-grained overbank and lacustrine deposits in the Ringold Formation locally form confining layers for Ringold fluvial gravels (units $A, B, D, C$ ) underlying unit $E$. The uppermost aquifer system is bounded laterally by anticlinal basalt ridges and is approximately $152 \mathrm{~m}$ $(500 \mathrm{ft})$ thick near the center of the Pasco Basin.

Sources of natural recharge to the uppermost aquifer system are rainfall and runoff from the higher bordering elevations, water infiltrating from small ephemeral streams, and river water along influent reaches of the Yakima and Columbia Rivers. The movement of precipitation through the unsaturated (vadose) zone has been studied at several locations on the Hanford Site (Gee 1987; Routson and Johnson 1990; Rockhold et al. 1990). Conclusions from these studies vary. Gee (1987) and Routson and Johnson (1990) concluded that little, if any, downward percolation of precipitation occurs on the 200 Area Plateau where the sediments are layered and vary in texture, and that all moisture penetrating the soil is removed by evapotranspiration. Rockhold et al. (1990) suggested that downward water movement below the root zone is common in the 300 Area, where soils are coarse textured. 
Artificial recharge of the uppermost aquifer system occurs from the disposal of large volumes of wastewater on the Hanford Site (principally in the 200 Areas), and from large irrigation projects surrounding the Hanford Site. Figures 21 and 22 11lustrate the groundwater table for the Hanford site during the periods of January 1944 and June 1989. Effluent disposal at the Hanford Site altered these hydraulic gradients and flow directions. Before operations at the Hanford Site began in 1944, the hydraulic gradient in all but the southwesternmost portion of the Hanford Site was approximately $1.5 \mathrm{~m} / \mathrm{km}$ (5 ft/mi). Regional groundwater flow generally was toward the eastnortheast, although flow north of Gable Mountain was more to the north. Groundwater flow north of Gable Mountain now trends in a more northeasterly direction resulting from mounding near reactors and flow through Gable Gap. Flow south of Gable Mountain is redirected locally by the groundwater mounds in the 200 Areas. There is also a component of groundwater flow to the north between Gable Mountain and Gable Butte from the 200 Areas.

Wastewaters discharged on the Hanford Site have contaminated large areas of the unconfined aquifer and a portion of the confined aquifer (Rattiesnake Ridge interbed). The primary contaminants that have reached the upper confined aquifer and the uppermost aquifer system are tritium, iodine-129, ruthenium-106, technetium-99, uranium, nitrate, and chromium (DOE 1987). The groundwater is routinely and extensively monitored to record the movement of contaminants and to determine any impact from the Hanford Site to the public. Groundwater monitoring reports are produced annually (e.g., Serkowski and Jordan 1989).

Temporary reversal of groundwater flow entering the Columbia River may occur during transient, high-river stages. This occurrence is known as bank storage. Newcomb and Brown (1961) made correlations between groundwater level and river-stage fluctuations along a $81-\mathrm{km}(50-\mathrm{mi})$ reach of the Columbia River adjacent to the Hanford Site. Newcomb and Brown (1961) concluded that a 260- $\mathrm{km}^{2}\left(100-\mathrm{mi}^{2}\right)$ area within the Hanford Site was affected by bank storage. During a 45-day rise in river stage, it was estimated that water infiltrated at an average rate of $111 \mathrm{~m}^{3} /$ day $\left(3,700\right.$ acre-ft/day) versus $30 \mathrm{~m}^{3} /$ day (1,000 acre-ft/day) during the 165-day recession period (time between consecutive storage events). In subsequent years dam control on the columbia River has reduced the magnitude of bank storage fluctuations on the groundwater system.

\subsubsection{0-N Area Hydrology}

The hydrology summarized in this entire section was taken from the work of Hartman (1993) on the 100-N RCRA sites. 
Figure 21. Hindcast Water Table Map of the Hanford Site, January 1944 (ERDA 1975).

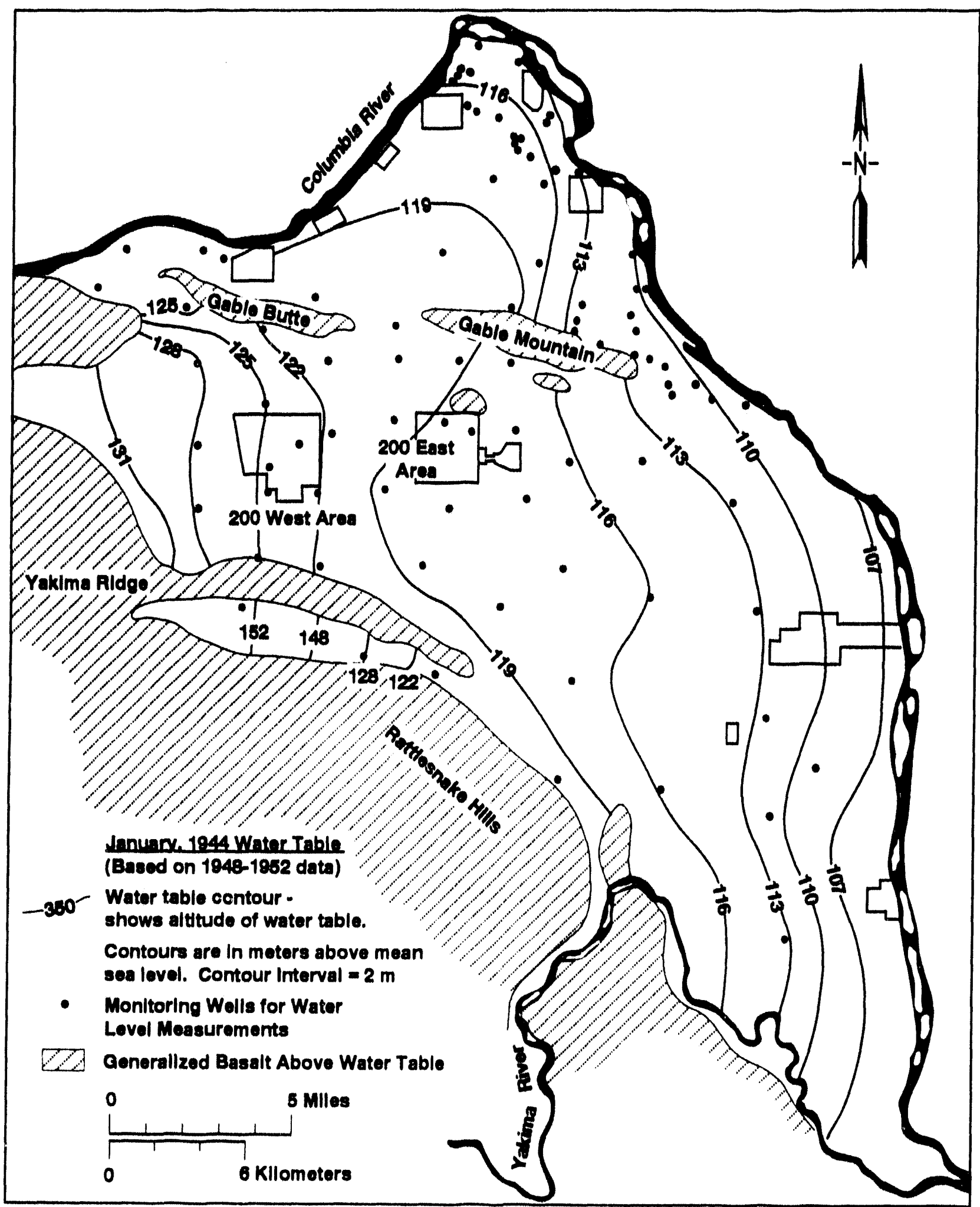

Hos07008.1 
Figure 22. Hanford Site Water Table Map, June 1989 (Smith et a1. 1989).

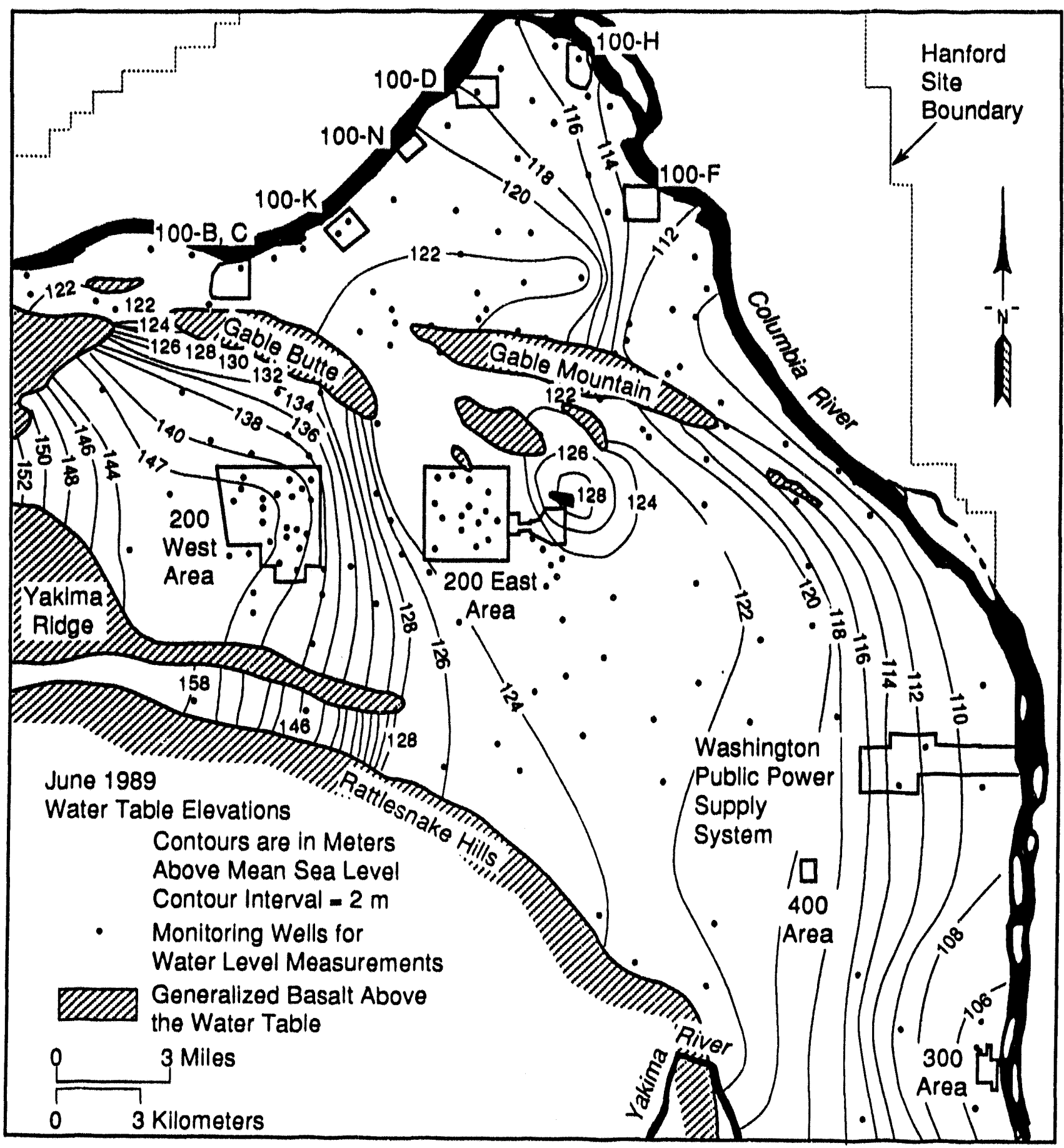

H9102019.5 
Most of the wells in the 100-N Area are relatively shallow, so information regarding hydrologic conditions at greater depths is 1 imited. The current conceptualization of the 100-N Area hydrostratigraphy is shown in Figure 23. It comprises the following major hydrostratigraphic units:

- Surface water

- Vadose zone

- Unconfined aquifer

- Ringold confined aguifer system

- Basalt and interbed aquifer system.

In the following discussion and in the rest of this document, 100-N Area well numbers, normally written as 199-N-\#, will be abbreviated $\mathrm{N}-\#$. Monitoring well locations are shown in Figure 24.

4.1.4.1 Surface Water. The Columbia River is the only natural surface water feature affecting the 100-N Area. The river stage is regulated by the dams upstream, and dally fluctuations of $2 \mathrm{~m}(6 \mathrm{ft})$ are common. The river stage usually fluctuates 2 to $3 \mathrm{~m}(8$ to $10 \mathrm{ft}$ ) through the year. Continuous river stage ineasurements are avallable from the 100-N Gaging Station.

The following waste treatment and liquid effluent disposal units in the 100-N Area have been sources of artificlal groundwater recharge (see Figure 13). As a result, mounds in the water table developed beneath these disposal sites and local groundwater flow patterns were altered.

- 1301-N LWDF--An unlined crib and trench that was used for disposal of cooling water from the $N$ Reactor from 1963 to 1985. Discharge rate was approximately $6,435 \mathrm{~L} / \mathrm{min}(1,700 \mathrm{gal} / \mathrm{min})$.

- 1325-N LWDF--Replaced 1301-N LWDF in 1985. Total flow to the 1325-N LWDF during normal reactor operation was 3,407 to $6,057 \mathrm{~L} / \mathrm{min}$ ( 900 to $1,600 \mathrm{gal} / \mathrm{min}$ ). Current discharge rate is zero (since Apri1 1991).

- 1324-NA Percolation Pond--An unlined pond that received wastes from 1977 to August 1990. Discharge rates averaged approximately $1,136 \mathrm{~L} / \mathrm{min}(300 \mathrm{gal} / \mathrm{min})$ when the pond was receiving filter backwash water as well as regeneration wastes and cooling water. The filter backwash was rerouted to another facllity in 1983.

- Backwash Lake--Disposal site for nonregulated waste from the 183-N Filtered Water Plant. Has received effluent since 1983. Estimated volume of discharge averaged 1,135,620 L/day $(300,000 \mathrm{gal} /$ day). Current and expected future discharge rate averages approximately $42 \mathrm{~L} / \mathrm{min}(11 \mathrm{gal} / \mathrm{min})$.

- 100-N Area Sewage Lagoon--Three ponds (aeration, stabilization, and infiltration) that are used to treat the waste discharged to the 100-N Sanitary Sewer System (Figure 25). Waste is also trucked in from septic tanks in the Hanford Site. Both trucked-in and piped-in wastes are discharged directly into the aeration pond (WHC 1993). 
Figure 23. Conceptual Drawing of Hydrogeologic Units in the 100-N Area (Hartman 1993).

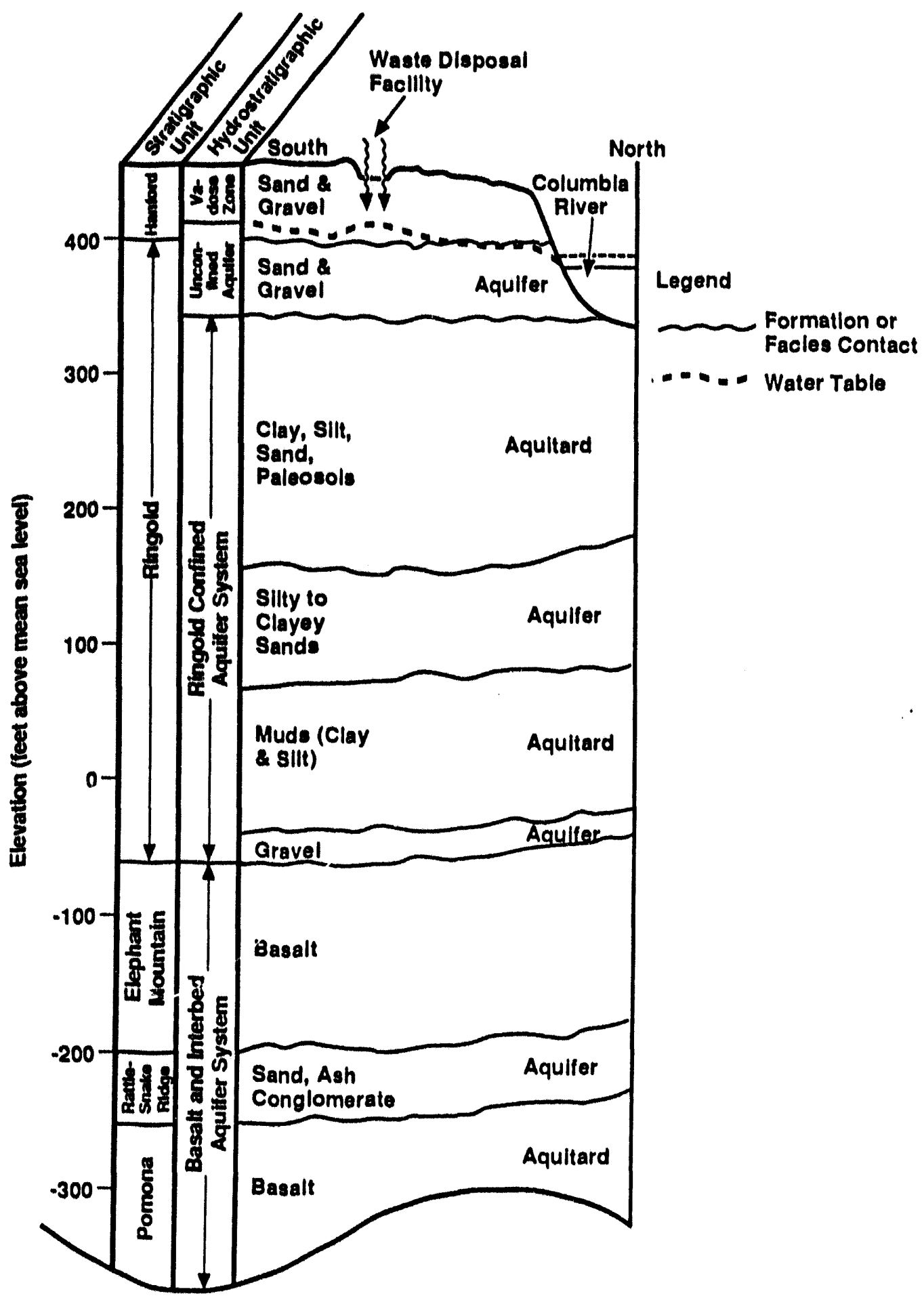

79007010.5 


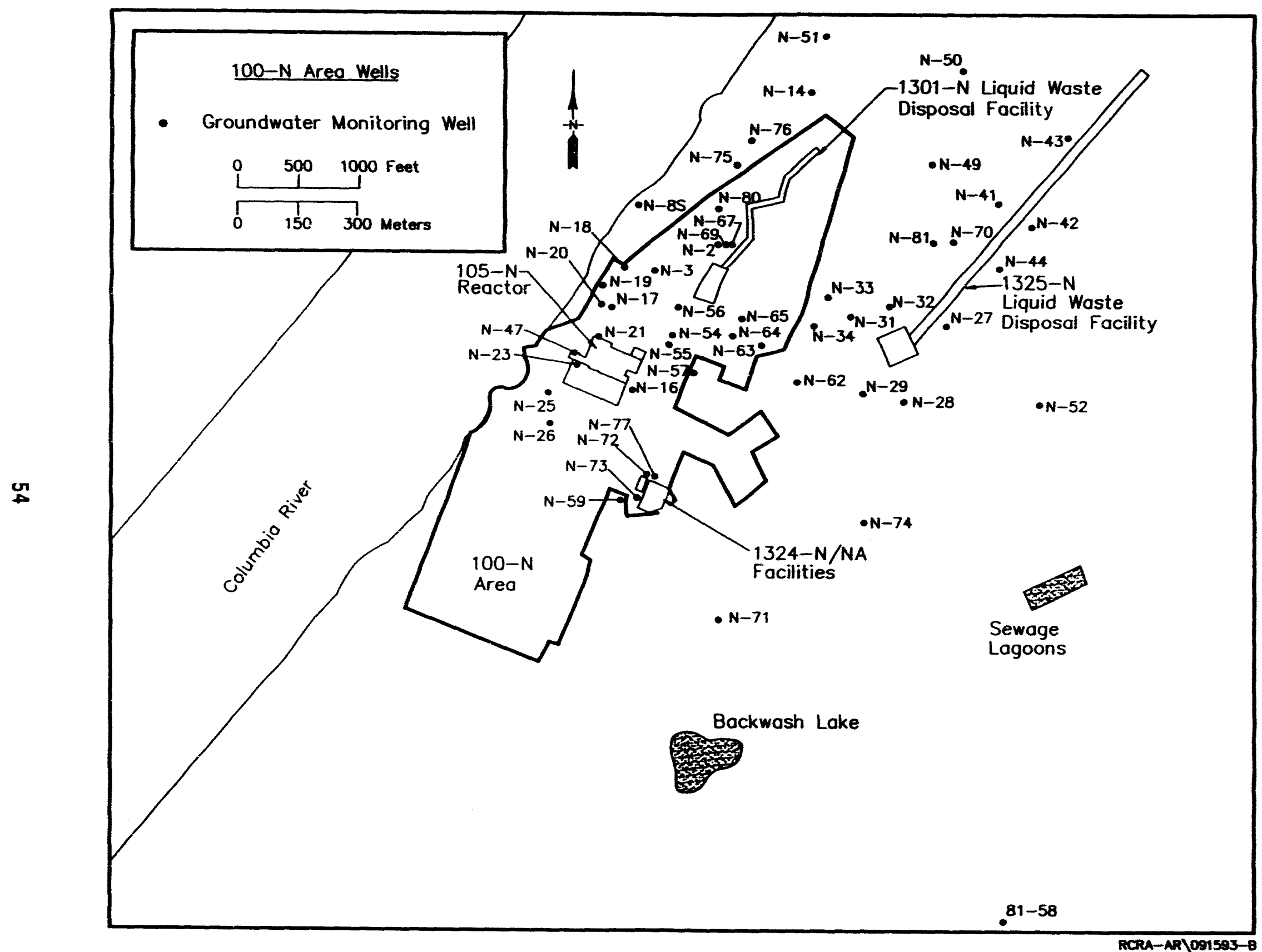

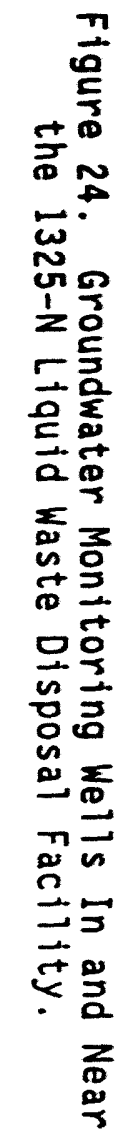


WHC-EP-0675

Figure 25. 100-N Area Sewage Lagoon (WHC 1993).

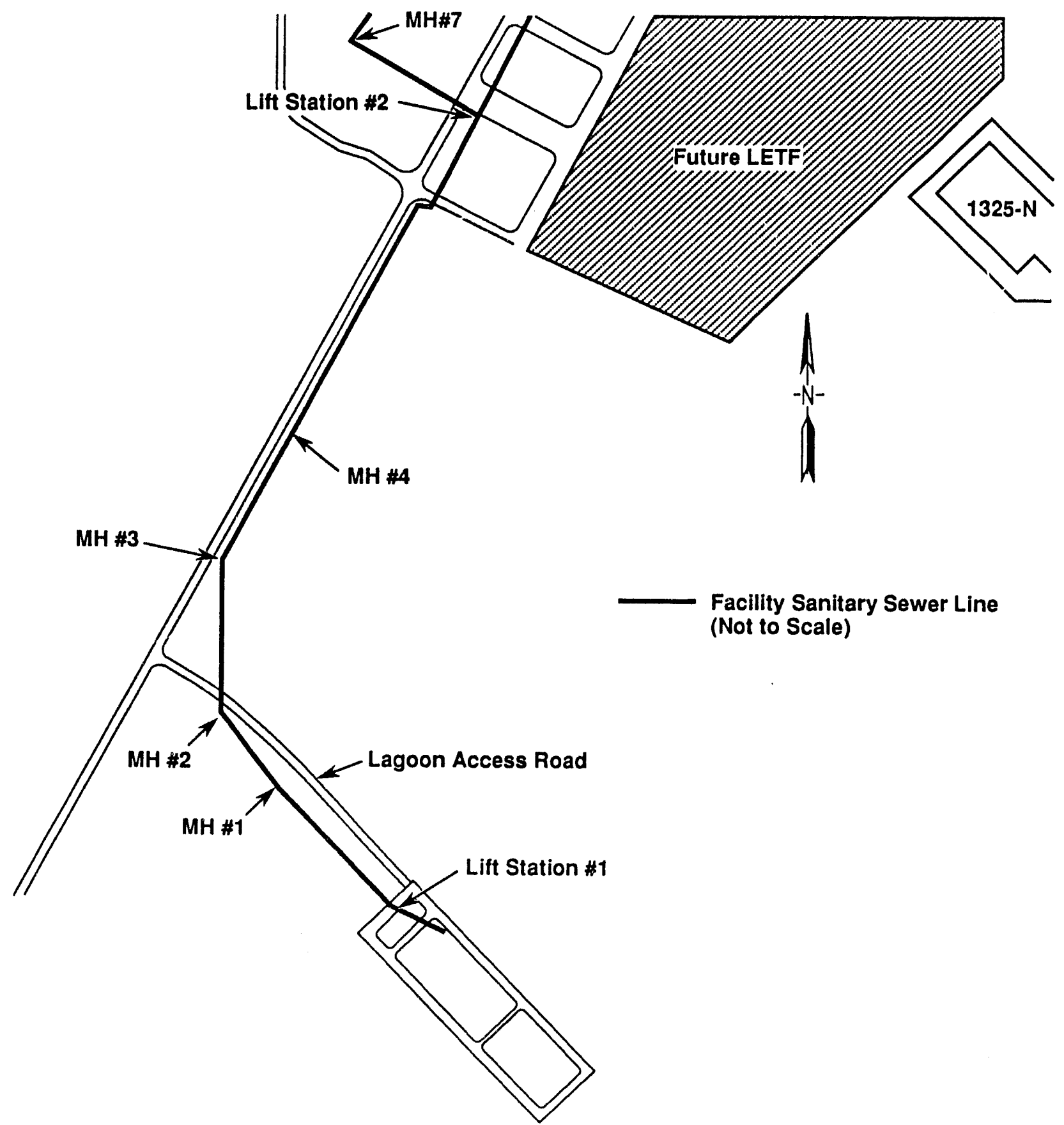

H9309026.4 
Locally, groundwater flows toward the Columbia River. However, during times of high river stage, water may flow from the river into the aquifer. This reversed gradient occasionally extends as far inland as the 1301-N LWDF (see Figure 13).

Groundwater also enters the Columbia River in the 100-N Area via a series of seeps, known collectively as "N Springs". They are located along the bank of the river, adjacent to the 1301-N LWDF, and extend approximately $2.7 \mathrm{~km}$ $(1.7 \mathrm{mi})$ downstream. These seeps, particularly those located nearest the 100-N Area, appear to be related to increased groundwater levels resulting from effluent discharged to the ground. Now that effluent discharge to the ground virtually has ceased, there are fewer seeps. The remaining seeps discharge at a lower rate. When the river stage drops, return flow from bank storage also contributes to the $N$ Springs discharges. Water samples from $N$ Springs are analyzed annually. Recent spring sampling occurred as part of the 100 Areas Comprehensive Environmental Response, Compensation, and Liability Act of 1980 (CERCLA) remedial investigations. The sampling focused on chemical contaminants as well as radionuclides (DOE-RL 1992C). It produced new data for many chemical indicators of Hanford Site contaminants, more widespread observations of chemical and radionuclide distributions, and an additional data set from which trend information can be derived. Locations of the seepage areas sampled are shown in Figure 26 (Peterson and Johnson 1992).

4.1.4.2 Vadose Zone. The vadose zone beneath the 100-N Area comprises primarily unconsolidated sediments of the Hanford formation. This highly permeable unit is composed mainly of cobbles, boulders, gravel, and coarse sand. Drilling data indicate that isolated lenses of silty sand and gravel are also present. The vadose zone also includes the top few feet (couple of meters) of the Ringold Formation in some parts of the area. These sediments are similar to the Hanford formation: sands, gravels, and cobbles, with varying fractions of silt.

Perched water was noted during drilling of well $\mathrm{N}-35$ at a depth of approximately $9 \mathrm{~m}(30 \mathrm{ft})$. Well $\mathrm{N}-35$, located immediately adjacent to the 1325-N LWDF crib, was installed after effluent disposal to that unit had begun.

The vadose zone in the $100-N$ Area ranges in thickness from 0 to $21 \mathrm{~m}$ ( 0 to $70 \mathrm{ft}$ ), going from the river in the west to the eastern edge of the area. The thickness of the vadose zone beneath the 100-N Area RCRA sites is 18 to $21 \mathrm{~m}$ (60 to $70 \mathrm{ft}$ ). Soil moisture data for the 100-N Area are 1imited, and range from 1 to $3 \%$ for sediments not moistened by effluent disposal (Hartman 1992).

4.1.4.3 Unconfined Aquifer. The unconfined aquifer in the 100-N Area is approximately 12 to $15 \mathrm{~m}$ ( 40 to $50 \mathrm{ft}$ ) thick and is situated primarily in the upper part of the Ringold Formation. In some locations, overlying portions of the Hanford formation were also saturated where groundwater mounds were present. The base of the aquifer is believed to be a laterally continuous clay-rich unit containing a series of paleosols. Lithologies in this unit are believed to range from clay and silt to sand. Most of the wells in the 100-N Area were completed in the upper portion of the unconfined aquifer; therefore, the thickness of the clay-rich unit is not known precisely at all locations. It is also not known if this clay-rich unit fully isolates the 
Figure 26. Location Map Showing 1991 Shoreline Sampling Locations (Peterson and Johnson 1992).

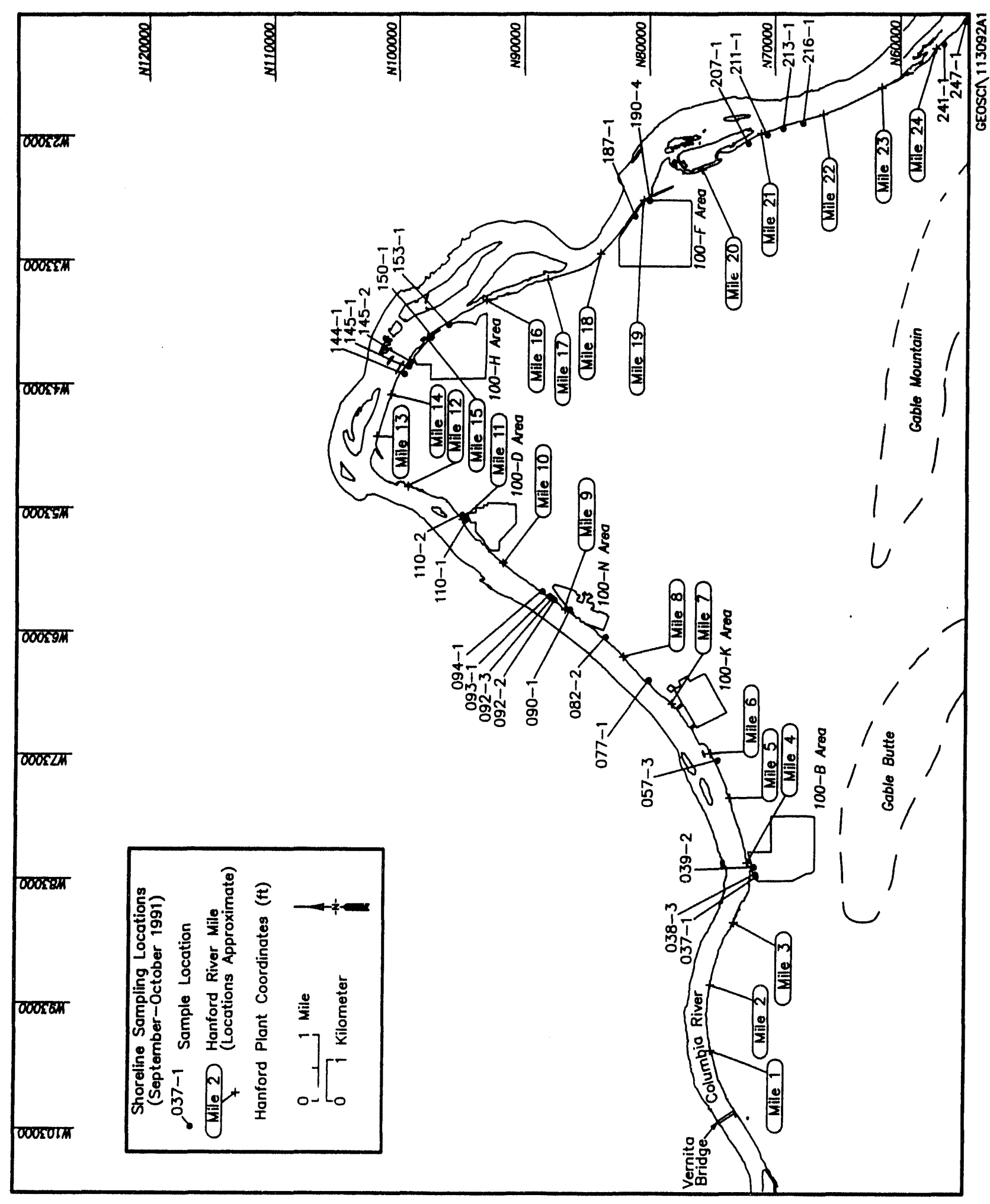


unconfined aquifer from the underlying hydrologic units. There may be hydraulic communication between water-bearing units in the Ringold formation (Hartman 1992a).

\subsection{HYDROLOGIC RESPONSES TO EFFLUENT DISPOSAL}

During peak reactor operations effluent flow to the 1325-N LWDF was continuous at a rate of approximately 3,785 to $6,057 \mathrm{~L} / \mathrm{min}(1,000$ to $1,600 \mathrm{gal} / \mathrm{min})$ and could increase to $7,570 \mathrm{~L} / \mathrm{min}(2,000 \mathrm{gal} / \mathrm{min})$ during specific operations. Sources from other reactor support facilities were more intermittent (see Table 1). Over its period of operation, the 1325-N LWDF has had a significant effect on the water table in its vicinity. Figures 27,28 , 29, and 30 show changes in the water table between June 1988 and January 1993. Over the years there have been mounds under many of the effluent disposal sites. In Figures 27 through 30, there is evidence of mounding from the 1324-N/NA, 1325-N LWDF, and potentially the backwash lake. Figure 31 shows a conceptualization of groundwater flow in the 100-N Area during active discharging of liquid effluents. The active discharge unit shown in Figure 27 is an area of groundwater recharge; mounding creates a vertical component of water movement beneath the site. On a local scale, groundwater flows radially outward from the groundwater mound. However, the overall direction of flow in the uppermost aquifer is toward the Columbia River, which is characteristic of areas or groundwater discharge (Hartman 1993).

The groundwater appears to be reverting back to a natural/preHanford Site flow regime. Several factors illustrate this effect:

- Discharge to the 1325-N LWDF has not occurred since April 1991

- Recharge to the unconfined aquifer from 1989 to 1991 was minimal compared to the effects from changes in river stage

- Since June 1989, water levels beneath the 100-N Area have dropped over $6 \mathrm{~m}(20 \mathrm{ft})$ and the groundwater mound beneath 1325-N LWDF declined and dissipated

- The groundwater gradient has decreased from 0.01 in June of 1989 to 0.001-0.002 in January of 1993.

\subsection{GROUNDWATER QUALITY}

In general, parameters of concern in the 100 Areas are gross alpha, gross beta, tritium, nitrate, and chromium. Plume maps have been generated for all of these contaminants (Hartman and Peterson 1992). These contaminants are highly mobile in groundwater and were present in waste liquids and reactor coolant released in the 100 Areas. There is also evidence of tritium migrating from the 200 Areas northward through Gable Gap and towards the river. Several wells in the Gable Gap area and northward towards 100-K Area show elevated concentrations of tritium (Hartman and Peterson 1992). 


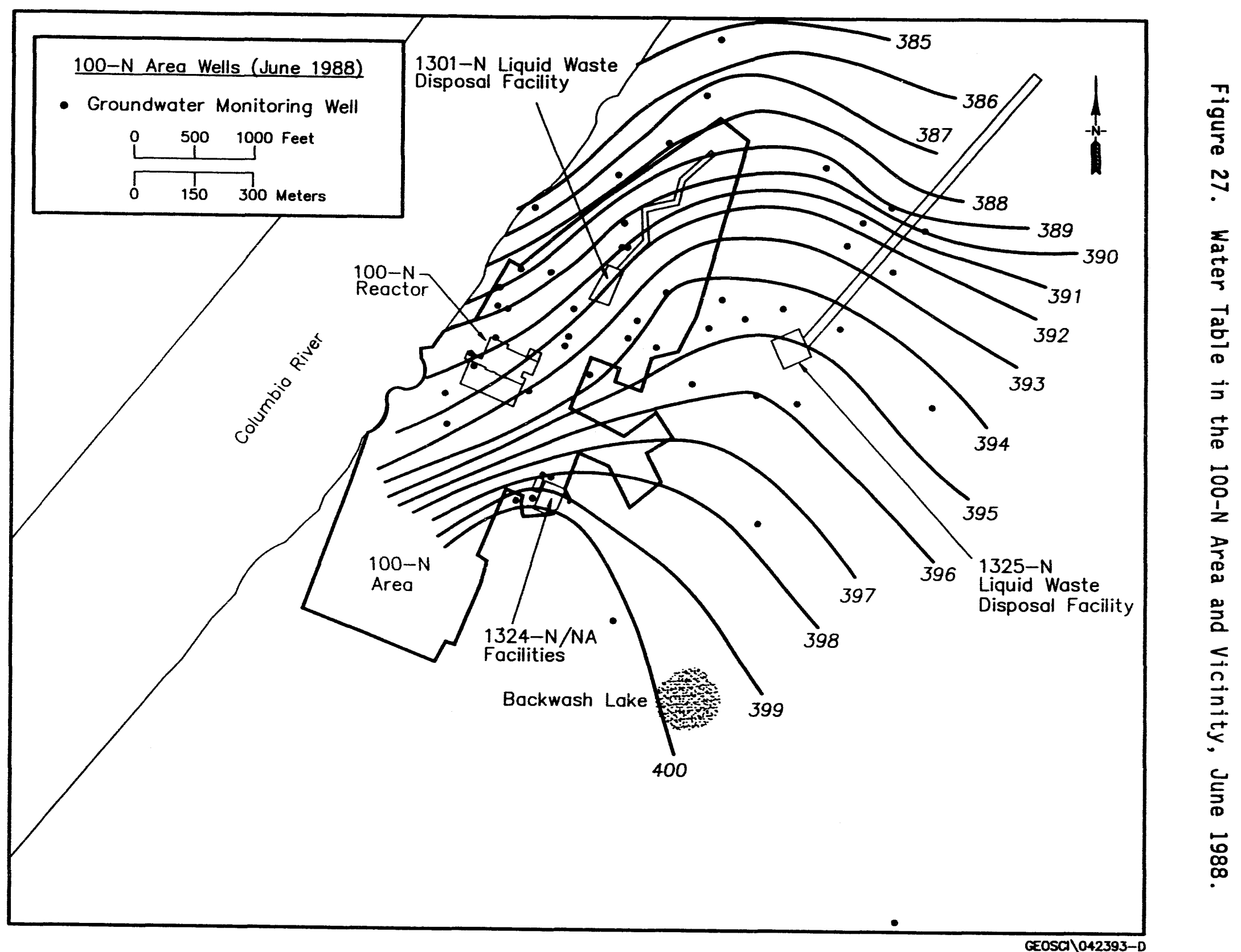




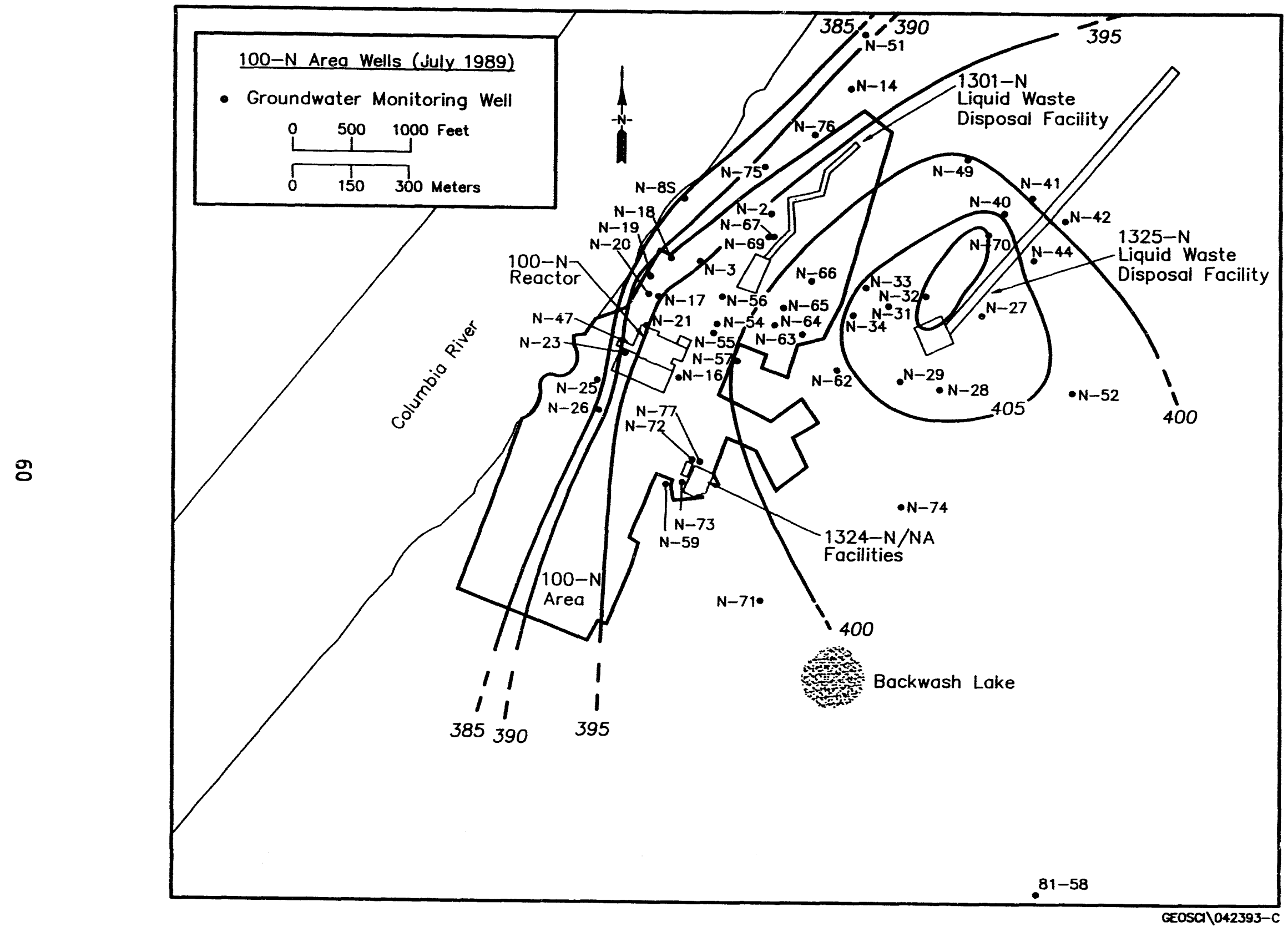

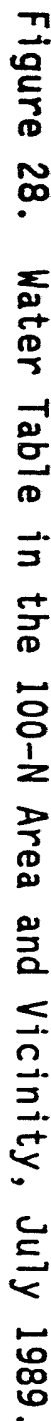




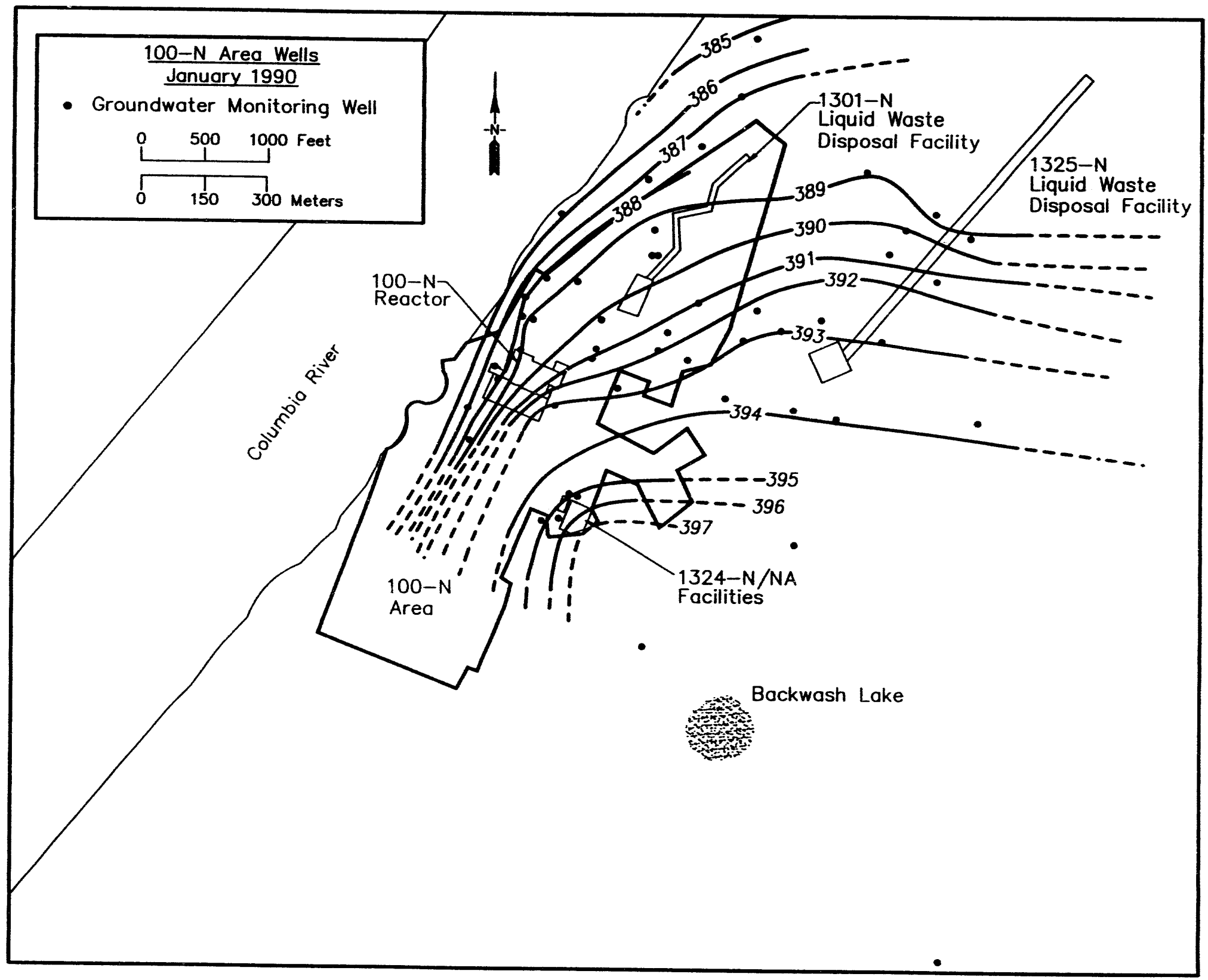

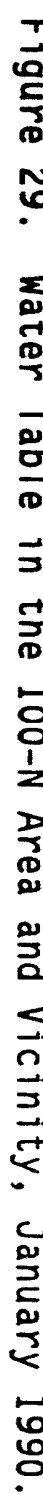




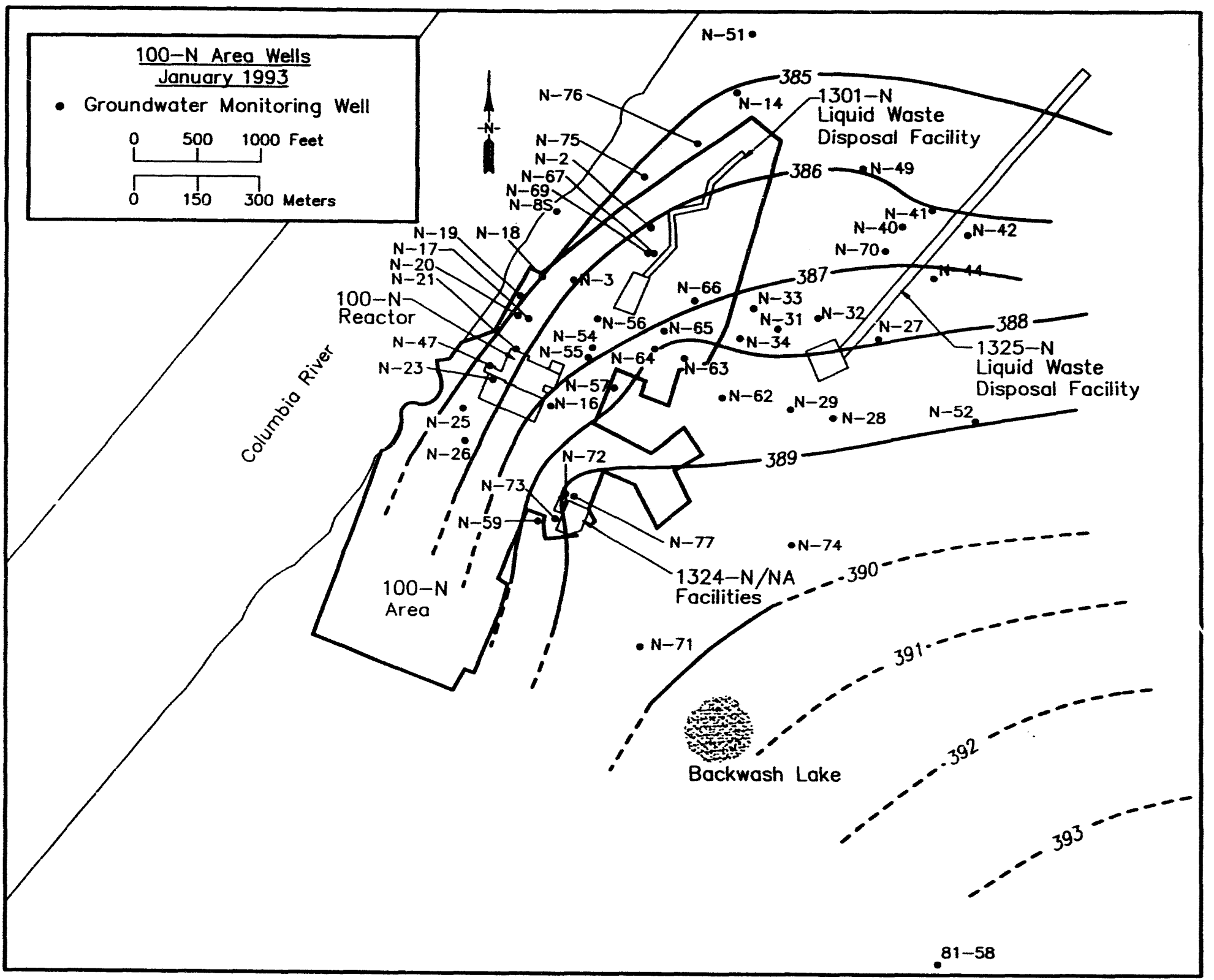

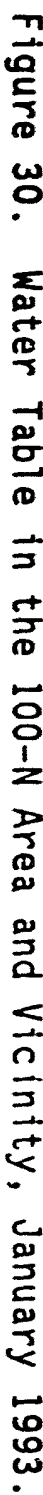

RCRA-AR \041993- 
Figure 31. Conceptual Drawing of Groundwater Flow in the Uppermost Aquifer at the 100-N Area (Hartman 1993).

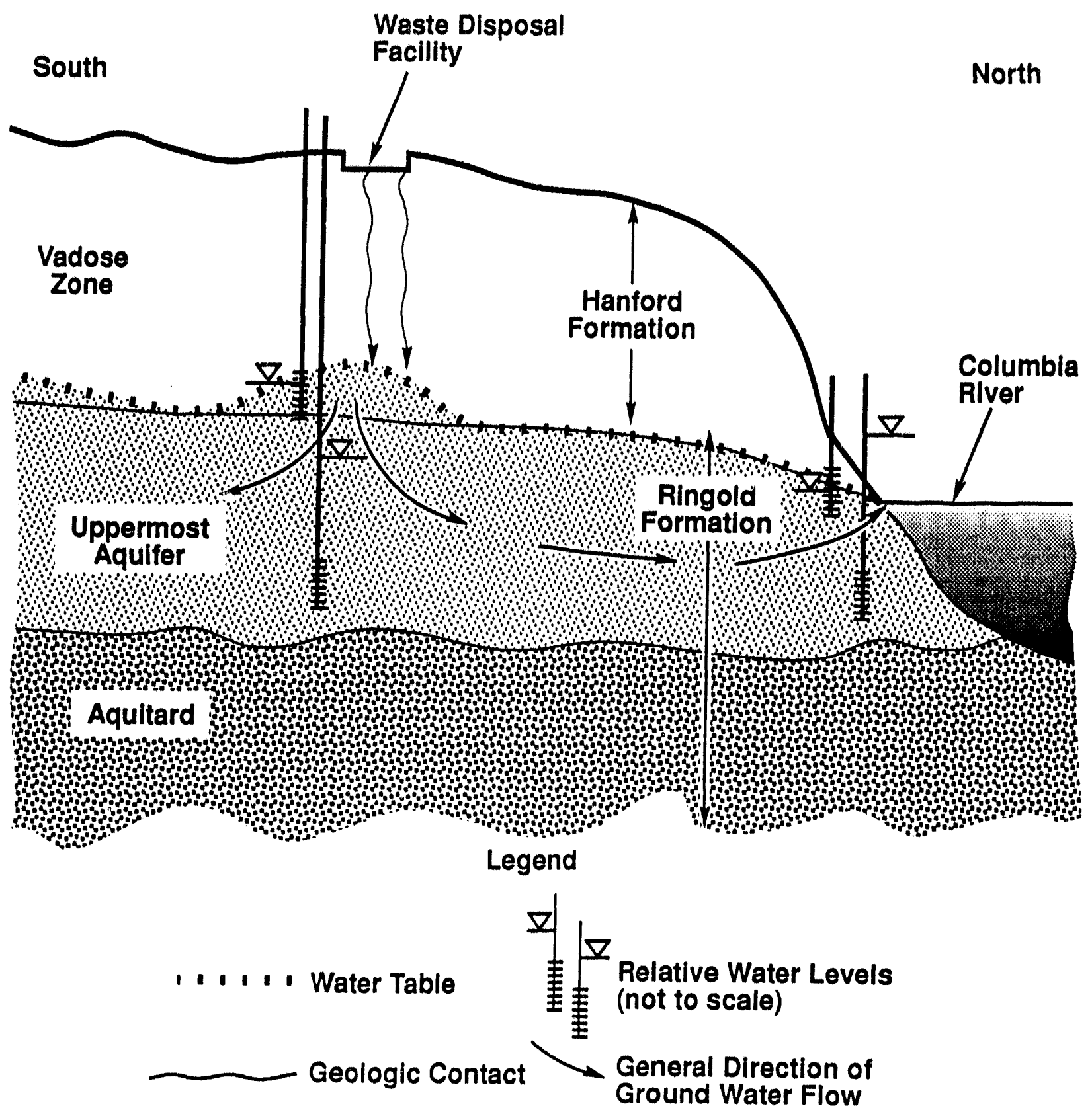

H9209Q26.1 
Hartman and Peterson (1992) present interpretations of groundwater chemistry for the 100-N Area based on data collected in 1990. At that time, groundwater beneath most of the 100-N Area appeared to be contaminated by gross beta and tritium. Gross alpha was below the detection 11 mit in the sampled wells. Nitrate was elevated above background in a few isolated wells, but below the drinking water standard. Chromium was less than or at the detection limit in the sampled wells.

The RCRA Groundwater Monitoring Programs for the 1301-N LWDF, the 1325-N LWDF, and the 1324-N/NA Facilities have identifled the primary contaminants present in the groundwater in the 100-N Area. Monitoring data are reported in the RCRA Quarterly Reports. Interpretations of the data are presented in the RCRA Annual Reports. This report relies on the two most recent annual reports (DOE-RL 1992a, DOE-RL 1993).

Hydrochemical results for the groundwater monitoring wells at the 100-N Area were compared to Hanford sitewide natural background threshold values (BTV)-95\% confidence interval. This was to determine if the 100-N Area and the surrounding area unconfined aquifer differed in chemistry from the sitewide background values for the unconfined aquifer. The following assumptions apply to the data set used in this analysis.

(1) Data include RCRA, CERCLA, and Operational Programs sampling data that had been entered into the Hanford Environmental Information System (HEIS) database up to mid-August 1993.

(2) All data are from samples collected in the 1990's.

(3) The data given for a year were averaged for the year and are rounded to the nearest whole number.

(4) All data are for unfiltered samples; except for the metals, for which both filtered and unfiltered results were examined.

The results of this comparison are as follows:

- Groundwater Quality Parameters--pH values are all within the 7 to 8 range, with the exception of well $\mathrm{N}-73$. This particular well averages $\mathrm{pH}$ values near 9. This well exceeds the WWQS for $\mathrm{pH}(6.5$ to 8.5). It is immediately downgradient of the 1324-N/NA Factility, which is probably the cause of the elevated $\mathrm{pH}$ values. Pastpractice disposal activities, such as the neutralization of regeneration solutions, may have contributed excess alkaline solution or metal hydroxide precipitate (e.g., $\left.\mathrm{CaOH}_{2}-\mathrm{CaOH}^{-}\right)$to the immediate area.

Specific conductance concentrations range from 165 to $1400 \mu$ mhos $/ \mathrm{cm}$. Approximately half of the wells have concentrations above the site BTV of $539 \mu$ mhos/cm (Table 7). Concentrations that are elevated occur in we17s $\mathrm{N}-3, \mathrm{~N}-17, \mathrm{~N}-18, \mathrm{~N}-20, \mathrm{~N}-21, \mathrm{~N}-25, \mathrm{~N}-26, \mathrm{~N}-47, \mathrm{~N}-54$, $\mathrm{N}-55, \mathrm{~N}-56, \mathrm{~N}-57, \mathrm{~N}-58, \mathrm{~N}-59, \mathrm{~N}-60, \mathrm{~N}-61$, and $\mathrm{N}-73$. These elevated values may be attributed to several known contaminant sources in the vicinity of the wells (see Figure 24). A plume map for specific conductance is shown in Figure 32 . 
Table 7. Summary of Provisional Hanford Site Groundwater Background Values" (Johnson 1993). (3 sheets)

\begin{tabular}{|c|c|c|c|c|}
\hline $\begin{array}{l}\text { Const f tuant } \\
\text { (concentration) }\end{array}$ & PNL result ts" & $\begin{array}{l}\text { USGS results" } \\
\text { (sample size) }\end{array}$ & $\begin{array}{l}\text { WHC unconf ined" } \\
\text { (sample size) }\end{array}$ & $\begin{array}{c}\text { WHC provislonal } \\
\text { threshold } \\
\text { volues }\end{array}$ \\
\hline$\underset{\text { Aluminum }}{\text { Alupb) }}$ & $<2$ & ${ }_{(12)}^{110 \pm 139}$ & $\begin{array}{l}<200 \\
(50)\end{array}$ & $<200$ \\
\hline $\begin{array}{c}\text { Ammonlua } \\
(p p b)\end{array}$ & 450 & NA & $\begin{array}{l}<50 \\
(18)\end{array}$ & $<120$ \\
\hline $\begin{array}{c}\text { Arsenic } \\
\text { (ppob) }\end{array}$ & $3.9 \pm 2.4$ & $6.7 \pm \frac{(7)}{(7)}^{3.7}$ & $\begin{array}{c}85 \\
(14)\end{array}$ & 10 \\
\hline $\begin{array}{l}\text { Bariun } \\
\text { (ppb) }\end{array}$ & $42 \pm 20$ & ${ }_{(11)^{14}}$ & $41 \pm 2 \pm 20$ & 68.5 \\
\hline$\underset{\text { Bppb) }}{\operatorname{Beryll} \text { lium }}$ & $<0.3$ & NA & $\begin{array}{c}<5 \\
(16)\end{array}$ & $<5$ \\
\hline $\begin{array}{c}\text { Bismuth } \\
\text { (ppb) }\end{array}$ & $<0.02$ & NA & $\begin{array}{c}<5 \\
(4) \\
\end{array}$ & $<5$ \\
\hline $\begin{array}{l}\text { Boron } \\
\text { (ppb) }\end{array}$ & 450 & $\begin{array}{l}<50 \\
(14)\end{array}$ & $\begin{array}{l}<100 \\
(35)\end{array}$ & $<100$ \\
\hline $\begin{array}{l}\text { Cectmilum } \\
\text { (ppob) }\end{array}$ & $<0.2$ & $\begin{array}{l}110 \\
\text { (1) }\end{array}$ & $\begin{array}{l}<10 \\
(16)\end{array}$ & $<10$ \\
\hline $\begin{array}{l}\text { Calcium } \\
\text { (ppo) }\end{array}$ & $40,400 \pm 10,300$ & $40,857 \underset{(14)}{ \pm} 8,282$ & 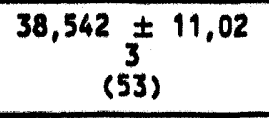 & 63,600 \\
\hline $\begin{array}{c}\text { chlorids-low } \\
\text { (ppb) }\end{array}$ & NA & $5,825 \pm 1,355$ & $5,032 \underset{(53)}{ \pm} 1,774$ & 8,690 \\
\hline $\begin{array}{c}\text { Chloride-high } \\
\text { (ppb) }\end{array}$ & NA & $20,667 \underset{(6)}{ \pm 2,503}$ & $23,296 \underset{(14)}{ \pm 2,463}$ & 28,500 \\
\hline $\begin{array}{c}\text { Chloride-all } \\
\text { (ppb) }\end{array}$ & $10,300 \pm 6,500$ & ${ }_{(14)}^{12,186 \pm 7,842}$ & ${ }_{(67)}^{8,848} \underset{7,723}{ \pm}$ & NC \\
\hline $\begin{array}{c}\text { Chromilu } \\
\text { (ppob) }\end{array}$ & $4 \pm 2$ & $\begin{array}{c}<50 \\
(11)\end{array}$ & $\begin{array}{l}830 \\
(8)\end{array}$ & $<30$ \\
\hline $\begin{array}{l}\text { Copper } \\
\text { (ppb) }\end{array}$ & $<1$ & $\begin{array}{l}<10 \\
(10) \\
\end{array}$ & $\begin{array}{l}<30 \\
(50) \\
\end{array}$ & $<30$ \\
\hline $\begin{array}{c}\text { Fluoride } \\
\text { (ppo) }\end{array}$ & $370 \pm 100$ & $\begin{array}{c}550 \pm 330 \\
(14)\end{array}$ & $437 \pm \frac{ \pm}{(47)} 131^{c}$ & $\begin{array}{l}1,340 \\
775^{c}\end{array}$ \\
\hline $\begin{array}{l}\text { Iron- low } \\
\text { (ppp) }\end{array}$ & NA & $22 \pm 16^{c}$ & $\begin{array}{l}<50 \\
(34)\end{array}$ & 86 \\
\hline $\begin{array}{c}\text { Iron-mid } \\
\text { (ppb) }\end{array}$ & NA & NA & ${ }_{(7)}^{115} 52$ & 291 \\
\hline $\begin{array}{l}\text { Iron-high } \\
\text { (ppob) }\end{array}$ & NA & NA & $494 \pm \frac{ \pm 118}{(12)}$ & 818 \\
\hline $\begin{array}{c}\text { Iron-all } \\
\text { (ppos) }\end{array}$ & NA & NA & $149 \underset{(53)}{ \pm} 199$ & NC \\
\hline $\begin{array}{l}\text { Lead } \\
\text { (ppb) }\end{array}$ & $<0.5$ & $\begin{array}{l}<30^{c} \\
(6) \\
\end{array}$ & $\begin{array}{r}<5 \\
(15) \\
\end{array}$ & $<5$ \\
\hline $\begin{array}{l}\text { Magnesiun } \\
\text { (ppb) }\end{array}$ & $11,800 \pm 3,400$ & $\underbrace{10,814 \pm 1,813}_{(14)}$ & $\frac{11,190 \pm 2,578}{(14)}$ & 16,480 \\
\hline $\begin{array}{c}\text { Manganese- low } \\
\text { (ppb) }\end{array}$ & NA & $\frac{26 \pm 27}{(8)}$ & $\begin{array}{l}<20 \\
(33)\end{array}$ & 24.5 \\
\hline $\begin{array}{c}\text { Manganese-high } \\
\text { (ppb) }\end{array}$ & NA & $150 \underset{(3)}{ \pm} 87$ & $\begin{array}{c}118 \pm 17 \\
(20)\end{array}$ & 163.5 \\
\hline $\begin{array}{c}\text { Manganese-all } \\
\text { (ppb) }\end{array}$ & $\cdots$ & ${ }_{(11)^{73}}$ & $50 \underset{(53)}{ \pm} 55$ & NC \\
\hline
\end{tabular}


Table 7. Summary of Provisional Hanford Site Groundwater Background Values (Johnson 1993). (3 sheets)

\begin{tabular}{|c|c|c|c|c|}
\hline $\begin{array}{l}\text { Const f tuent } \\
\text { (concentration) }\end{array}$ & PNL reaulta" & $\begin{array}{l}\text { Usos resultso } \\
\text { (sample size) }\end{array}$ & $\begin{array}{l}\text { WHC unconf ined } \\
\text { (sample ize) }\end{array}$ & $\begin{array}{c}\text { WHC provis lonal } \\
\text { threshold } \\
\text { values }\end{array}$ \\
\hline $\begin{array}{l}\text { Mercury } \\
\text { (ppb) }\end{array}$ & $\cdots$ & NA & $\begin{array}{l}<0.1 \\
(14)\end{array}$ & $<0.1$ \\
\hline $\begin{array}{l}\text { Mickel } \\
\text { (ppob) }\end{array}$ & 4 & $\begin{array}{l}450 \\
(16)\end{array}$ & $\begin{array}{l}<30 \\
(23)\end{array}$ & $<30$ \\
\hline $\begin{array}{l}\text { Nitrete } \\
\text { (pop) }\end{array}$ & MA & $3,226 \underset{(13)}{ \pm 3,380}$ & $5,170 \underset{(78)}{ \pm 3,576}$ & 12,400 \\
\hline $\begin{array}{l}\text { Phosphute } \\
\text { (ppb) }\end{array}$ & $<1,000$ & ${ }_{(3)}^{140} \pm 62$ & $<1,000$ & $<1,000$ \\
\hline $\begin{array}{l}\text { Potassiciu } \\
\text { (ppob) }\end{array}$ & $4,950 \pm 1,240$ & $5,900 \pm \frac{1,253}{(14)^{1}}$ & $4,993 \underset{(53)}{ \pm 1,453}$ & 7.975 \\
\hline $\begin{array}{c}\text { solenium } \\
(p p b)\end{array}$ & $<2$ & NA & $\begin{array}{l}85 \\
(14)\end{array}$ & 45 \\
\hline $\begin{array}{l}\text { sllver } \\
\text { (ppb) }\end{array}$ & $<10$ & NA & $<10$ & $<10$ \\
\hline $\begin{array}{l}\text { sillicon } \\
\text { (ppob) }\end{array}$ & NA & $16,786 \underset{(14)}{ \pm} 3,683$ & $\underset{(35)}{18,152 \pm 4,974}$ & 26,500 \\
\hline $\begin{array}{l}\text { sodiun } \\
\text { (ppob) }\end{array}$ & $18,260 \pm 10.150$ & $20,286 \underset{(14)}{ \pm} 7,907$ & $15,774{ }_{(53)}^{ \pm} 6,784$ & 33,500 \\
\hline $\begin{array}{l}\text { seront fun } \\
\text { (ppob) }\end{array}$ & $236 \pm 102$ & ${ }_{(14)}^{159} 78$ & ${ }_{(43)}^{164} 47$ & 264.1 \\
\hline $\begin{array}{l}\text { sulfete } \\
\text { (ppb) }\end{array}$ & $34,300 \pm 16,900$ & $41,286 \underset{(14)}{ \pm 27,880}$ & $\begin{array}{c}30,605 \pm 22,61 \\
1 \\
(67)\end{array}$ & 90,500 \\
\hline $\begin{array}{l}\text { Urenium } \\
(p \subset \mid / L)\end{array}$ & $1.7 \pm 0.8$ & NA & $1.7 \pm 1.2$ & 3.43 \\
\hline $\begin{array}{l}\text { Vanediun } \\
\text { (ppb) }\end{array}$ & $17 \pm 9$ & NA & $\begin{array}{c}9 \pm 4 \\
(18)^{4}\end{array}$ & 15 \\
\hline $\begin{array}{l}\text { 2inc-low } \\
\text { (ppo) }\end{array}$ & NA & $\begin{array}{l}14 \pm 20 \\
(11)^{2}\end{array}$ & $\begin{array}{l}<50 \\
(36)\end{array}$ & $<50$ \\
\hline$\underset{(p p b)}{2 \text { inc-high }}$ & NA & $373 \pm \frac{284}{(3)}$ & $247 \underset{(17)^{165}}{ }$ & 673 \\
\hline$\underset{(p p b)}{2 \text { inc-all }}$ & $6 \pm 2$ & $91 \underset{(14)}{ \pm 190}$ & $95 \underset{(53)}{ \pm} 140$ & NC \\
\hline $\begin{array}{c}\text { Field alkalime } \\
\text { (ppb) }\end{array}$ & MA & $134,100 \underset{(10)}{ \pm} 20,469$ & $\begin{array}{c}137,758 \pm 33,6 \\
56 \\
(31)\end{array}$ & 215,000 \\
\hline Lab alkaline & $123,000 \pm 21,000$ & $130,000 \pm 8,165$ & $\begin{array}{c}133,717 \\
99 \\
(52)\end{array}$ & 210,000 \\
\hline Field pH & NA & MA & $7.57 \underset{(57)}{ \pm} 0.29$ & {$[6.90,8.24]$} \\
\hline Lab PH & $7.64 \pm 0.16$ & NA & ${ }_{(52)} \pm 0.21$ & {$[7.25,8.25]$} \\
\hline $\begin{array}{c}\text { TOC } \\
(p p b)\end{array}$ & $586 \pm 347$ & NA & $\begin{array}{c}519 \pm 367^{\circ} \\
(62)\end{array}$ & $\begin{array}{l}2,610 \\
1,610^{\circ}\end{array}$ \\
\hline $\begin{array}{l}\text { Field cond. } \\
\text { ( } \mu \mathrm{mhos} / \mathrm{cm})\end{array}$ & NA & NA & $\begin{array}{c}344 \pm 83 \\
(22)^{8}\end{array}$ & 539 \\
\hline
\end{tabular}


Table 7. Summary of Provisional Hanford Site Groundwater Background Values" (Johnson 1993). (3 sheets)

\begin{tabular}{|c|c|c|c|c|}
\hline $\begin{array}{l}\text { Const i tuent } \\
\text { (concentration) }\end{array}$ & PNL results" & $\begin{array}{l}\text { USGS resultsb } \\
\text { (sample size) }\end{array}$ & $\begin{array}{l}\text { WHC unconfined } \\
\text { (sample size) }\end{array}$ & $\begin{array}{c}\text { WHC provislonal } \\
\text { threshold } \\
\text { values }\end{array}$ \\
\hline $\begin{array}{l}\text { Lab cond. } \\
\text { (Hmhos/an) }\end{array}$ & $380 \pm 82$ & MA & $\underset{(36)}{332 \pm 93}$ & 530 \\
\hline $\begin{array}{c}\text { TOX, LDL } \\
(p p b)\end{array}$ & MA & MA & $\begin{array}{l}<20^{\circ} \\
(14)\end{array}$ & $\begin{array}{l}60.8 \\
37.6^{\circ}\end{array}$ \\
\hline $\begin{array}{c}\text { Toc } \\
\text { (ppb) }\end{array}$ & MA & MA & $31,772 \underset{(48)}{ \pm} 7,022$ & 50,100 \\
\hline $\begin{array}{l}\text { Orows olpha } \\
(p c \mid / L)\end{array}$ & $2.5 \pm 1.4$ & MA & $2.5 \pm \frac{ \pm 1.5^{6}}{(36)}$ & $5.79^{\circ}$ \\
\hline $\begin{array}{l}\text { Grose beta } \\
(\mathrm{pc} / / \mathrm{L})\end{array}$ & $19 \pm 12$ & NA & $7.1 \pm 2.6^{\circ}$ & $\begin{array}{l}35.5 \\
12.62^{\mathrm{c}}\end{array}$ \\
\hline $\begin{array}{l}\text { Redium } \\
\text { (pcl/h) }\end{array}$ & $<0.2$ & NA & $\begin{array}{l}\text { ND } \\
(10)\end{array}$ & 0.23 \\
\hline
\end{tabular}

'Source: From Tablas 5-9 and 5-11 of DOE-RL (1992b).

Results shown are mean \pm one standard deviation.

"Potential outlier observation(s) were removed.

LDL - lower detection limit.

MA = not available.

NC = not calculated.

MO a not detected.

PNL = Pacifle Northwest Laboratory.

ppb - parts par billion.

TOC = total organic carbon.

TOX = total organic halogen.

Uses = United states Geological survey.

WHC = Hestinghouse Hanford Company. 


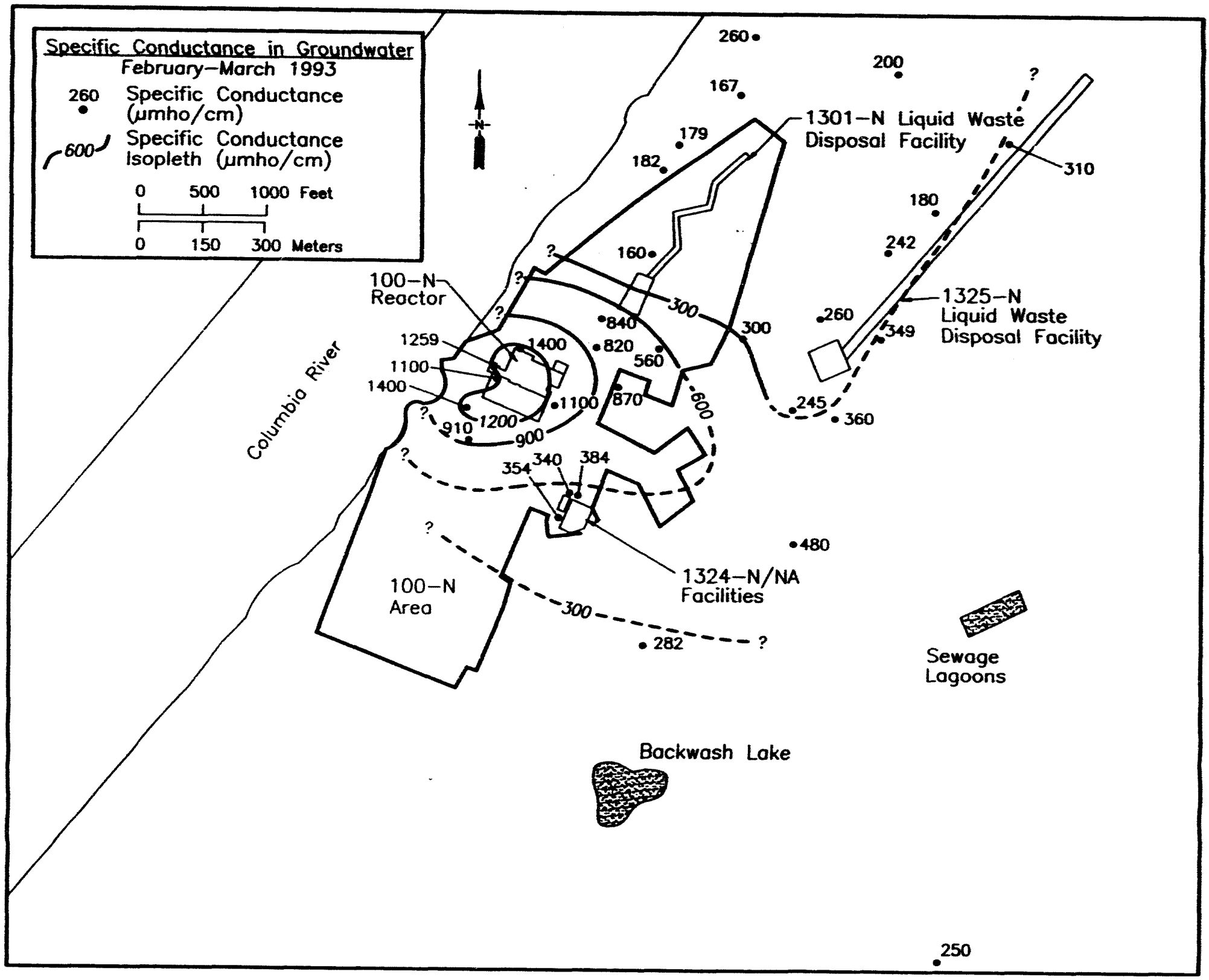

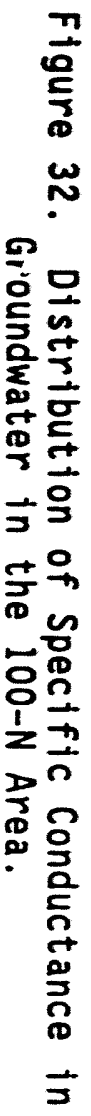


Alkalinity concentrations in most of the area are below the BTV (215 ppm) for the site unconfined aquifer (see Table 7). Only one well (N-17), has a concentration that exceeds this (350 ppm). This well is located to the north of the 105-N/109-N Facility (see Figure 24). The cause of this high alkalinity value is unknown.

Total organic carbon is below the site BTV for the unconfined aquifer $(1,610$ parts per billion [ppb]) in all of the wells in the 100-N Area (see Table 9).

Turbidity values in the majority of the wells are all near normal values (<10 nephelometric turbidity unit). There are a few wells with values between 10 to 25 nephelometric turbidity unit ( $N-3$, $\mathrm{N}-16, \mathrm{~N}-26$, and $\mathrm{N}-34$ ). The first three wells are near the reactor and support facilities, and the last is downgradient of the 1325-N LWDF (see Figure 24). Three wells have values that range from 46 to 200 nephelometric turbidity unit $(N-25, N-41$, and $N-64)$. These wells are located southwest of the 105-N/109-N Facilities, northwest of the 1325-N LWDF trench, and southeast of the 1301-N LWDF crib, respectively. The cause of these higher turbidity values is unknown.

- Cation concentrations--Calcium concentrations ranged from 2,100 to $130,000 \mathrm{ppb}$. The site unconfined aquifer BTV is $63,600 \mathrm{ppb}$ (see Table 7). Less than half of the wells in the 100-N Area have values in excess of this BTV. There appears to be little difference between the unfiltered and filtered sample results. The majority of the wells with elevated concentrations are in the vicinity of the 105-N/109-N Facilities and 1301-N LWDF (see Figure 24).

Sodium concentrations ranged from 2,800 to $220,000 \mathrm{ppb}$ in the 100-N Area. The site BTV is approximately $33,500 \mathrm{ppb}$ for the unconfined aquifer (see Table 7). The results for filtered and unfiltered samples are very similar. The highest concentrations are found in wells $\mathrm{N}-16$ (175,00 ppb), N-21 (180,000 ppb), N-23 $(15,000 \mathrm{ppb}), \mathrm{N}-25(220,000 \mathrm{ppb}), \mathrm{N}-26$ (108,500 ppb), N-47 $(135,000 \mathrm{ppb}), \mathrm{N}-54(40,000 \mathrm{ppb}), \mathrm{N}-57(73,000 \mathrm{ppb}), \mathrm{N}-71$ $(41,500 \mathrm{ppb})$, and $\mathrm{N}-73(72,000 \mathrm{ppb})$, downgradient of the 1324-N/NA Facility (see Figure 24). The elevated sodium is a result of past-practice disposal activities at this facility. A plume map for sodium is shown in Figure 33 .

Potassium concentrations ranged from 960 to $8,000 \mathrm{ppb}$. The BTV for the unconfined aquifer onsite is approximately 7,975 ppb (see Table 7). Only one well (N-21) $(8,000 \mathrm{ppb})$ slightly exceeds this value.

Ammonium concentrations ranged from at or below the contractually required quantification limit (CRQL) of 100 to $700 \mathrm{ppb}$. The site BTV for the unconfined aquifer is less than $120 \mathrm{ppb}$ (see Table 7). Only seven wells show concentrations above $120 \mathrm{ppb}$. They are $\mathrm{N}-3$ (700 ppb), N-25 (250 ppb), N-28 (400 ppb), N-64 (300 ppb), N-69 (150 ppb), N-70 (200 ppb), and $N-73$ (150 ppb). These wells are located near several facilities (see Figure 24), making it difficult to draw specific conclusions as to a possible source. 


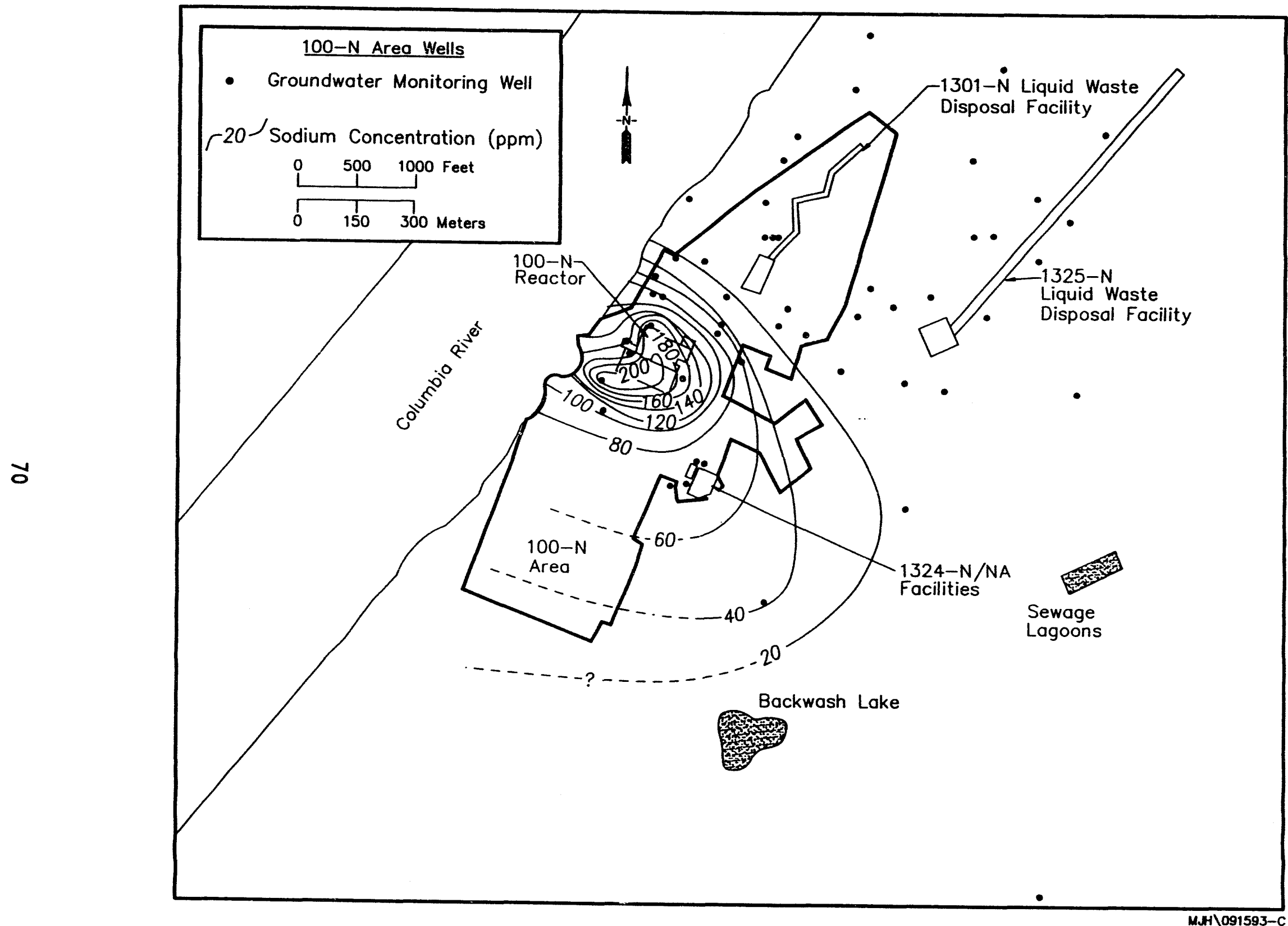

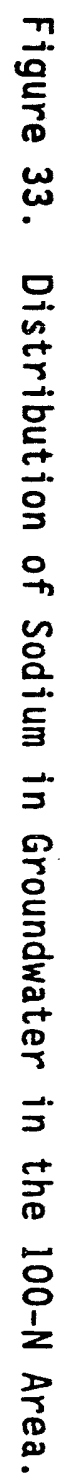


- Anion concentrations--Chloride concentrations ranged from 1,200 to $79,500 \mathrm{ppb}$ for wells in the 100-N Area. The BTV value for the site unconfined aquifer (see Table 7) ranges from 8,690 to 28,500 ppb (because of two populations of chloride). Well N-16 has a concentration of $79,500 \mathrm{ppb}$. Eight wells have concentrations greater than $10,000 \mathrm{ppb}: \mathrm{N}-3(16,000 \mathrm{ppb}), \mathrm{N}-17(17,000 \mathrm{ppb}), \mathrm{N}-21$ (14,500 ppb), N-26 (14,500 ppb), N-47 (11,400 ppb), N-54 (13,000 ppb), N-57 (16,000 ppb), and $\mathrm{N}-64(12,000 \mathrm{ppb})$. These eight wells are downgradient of the 1324-N/NA Facility (see Figure 24). The elevated chloride in the unconfined aquifer in 100-N Area is a result of past-practice disposal activities at the 1324-N/NA Facility. None of the wells exceeds the WWQS for chloride, which is $250,000 \mathrm{ppb}$. A plume map for chloride is shown in Figure 34.

Fluoride concentrations ranged from at or below the CRQL of 100 to $1,300 \mathrm{ppb}$. The site BTV for the unconfined aquifer is $775 \mathrm{ppb}$ (see Table 7). Seven wells are higher than the site BTV: $\mathrm{N}-17$ $(1,300 \mathrm{ppb}), \mathrm{N}-21$ (1,250 ppb), N-23 (1,000 ppb), N-25 (1,300 ppb), $\mathrm{N}-26(1,100 \mathrm{ppb}), \mathrm{N}-47(1,100 \mathrm{ppb})$, and $\mathrm{N}-73(1,150 \mathrm{ppb})$. These wells are located near several potential sources (see Figure 24).

Nitrate concentrations ranged from 900 to $50,000 \mathrm{ppb}$ in the 100-N Area. The site BTV for the unconfined aquifer is approximately 12,400 ppb (see Table 7). Nine wells have concentrations in excess of this value: $\mathrm{N}-3(20,000 \mathrm{ppb}), \mathrm{N}-16$ $(22,000 \mathrm{ppb}), \mathrm{N}-21(21,000 \mathrm{ppb}), \mathrm{N}-26(50,000 \mathrm{ppb}), \mathrm{N}-32$ (31,500 ppb), N-54 (15,000 ppb), N-56 (16,500 ppb), N-64 $(46,500 \mathrm{ppb})$, and $\mathrm{N}-70(13,400 \mathrm{ppb})$. The WWQS for nitrate as nitrogen is $10,000 \mathrm{ppb}$. All but 11 of the wells sampled exceed this value. The majority of the wells with elevated concentrations are located near past-practice disposal sites, but it is difficult to determine the source of the nitrate (see Figure 24). A plume map for nitrate is shown in Figure 35. Sewage effluent disposal to the ground may be a source of nitrate contamination. Another possibility is a chemical used for decontamination in the 100-N Area. Diethylthiourea is mixed with phosphoric acid for decontamination and contains amine groups $\left(\mathrm{C}_{2} \mathrm{H}_{5} \mathrm{NHCSNHC}_{2} \mathrm{H}_{5}\right)$. Nitrate concentrations that were higher than the surrounding 600 Area groundwaters were noted by Hartman and Peterson (1992) in their paper summarizing the hydrology of the northern Hanford Site.

Nitrite concentrations were at or below the CRQL of $200 \mathrm{ppb}$ for all but one well in the 100-N Area. Well N-3 had a concentration of $850 \mathrm{ppb}$. 
WHC-EP-0675

Figure 34. Distribution of Chloride in Groundwater in the 100-N Area.

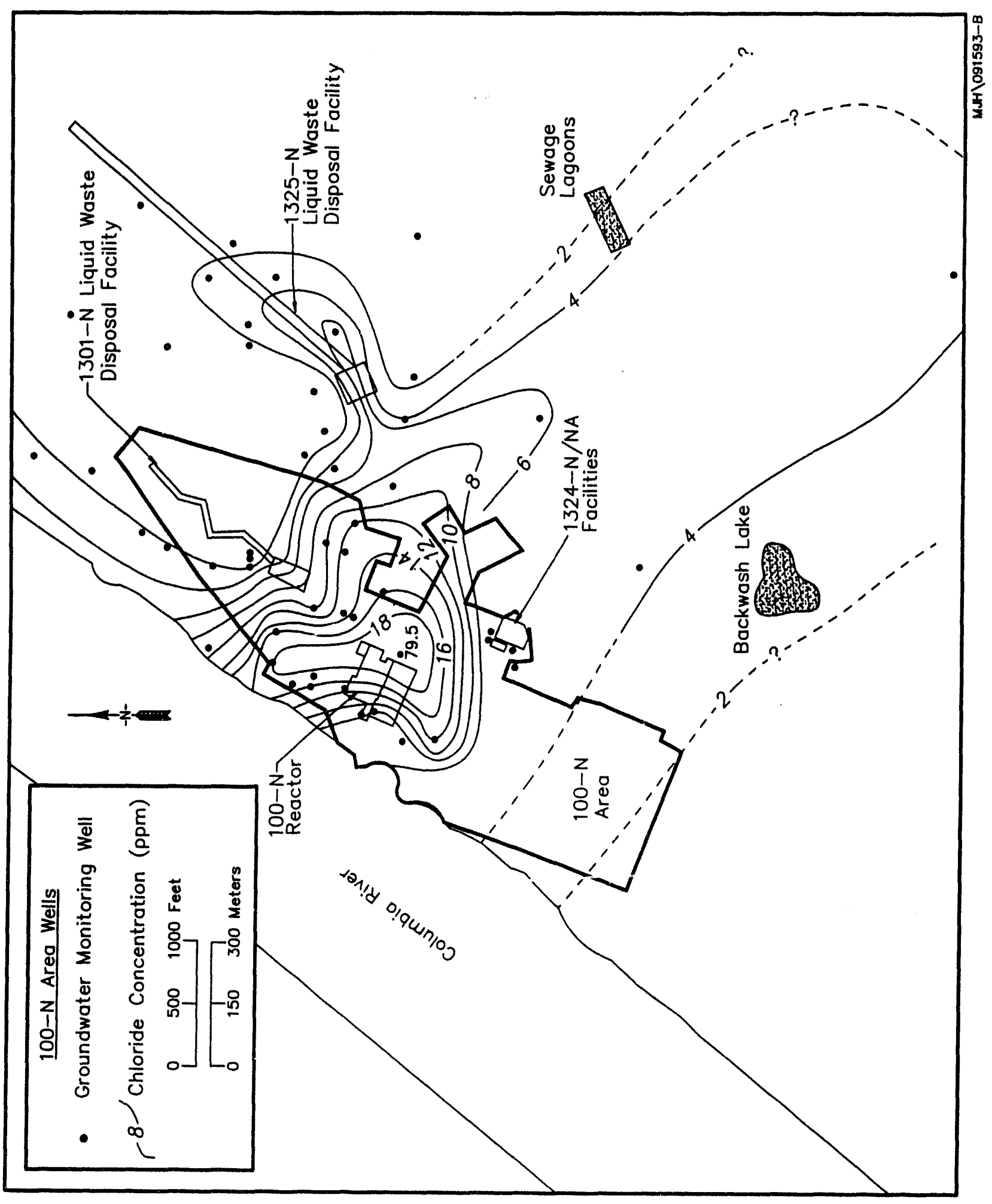


Figure 35. Distribution of Nitrate in Groundwater in the 100-N Area.

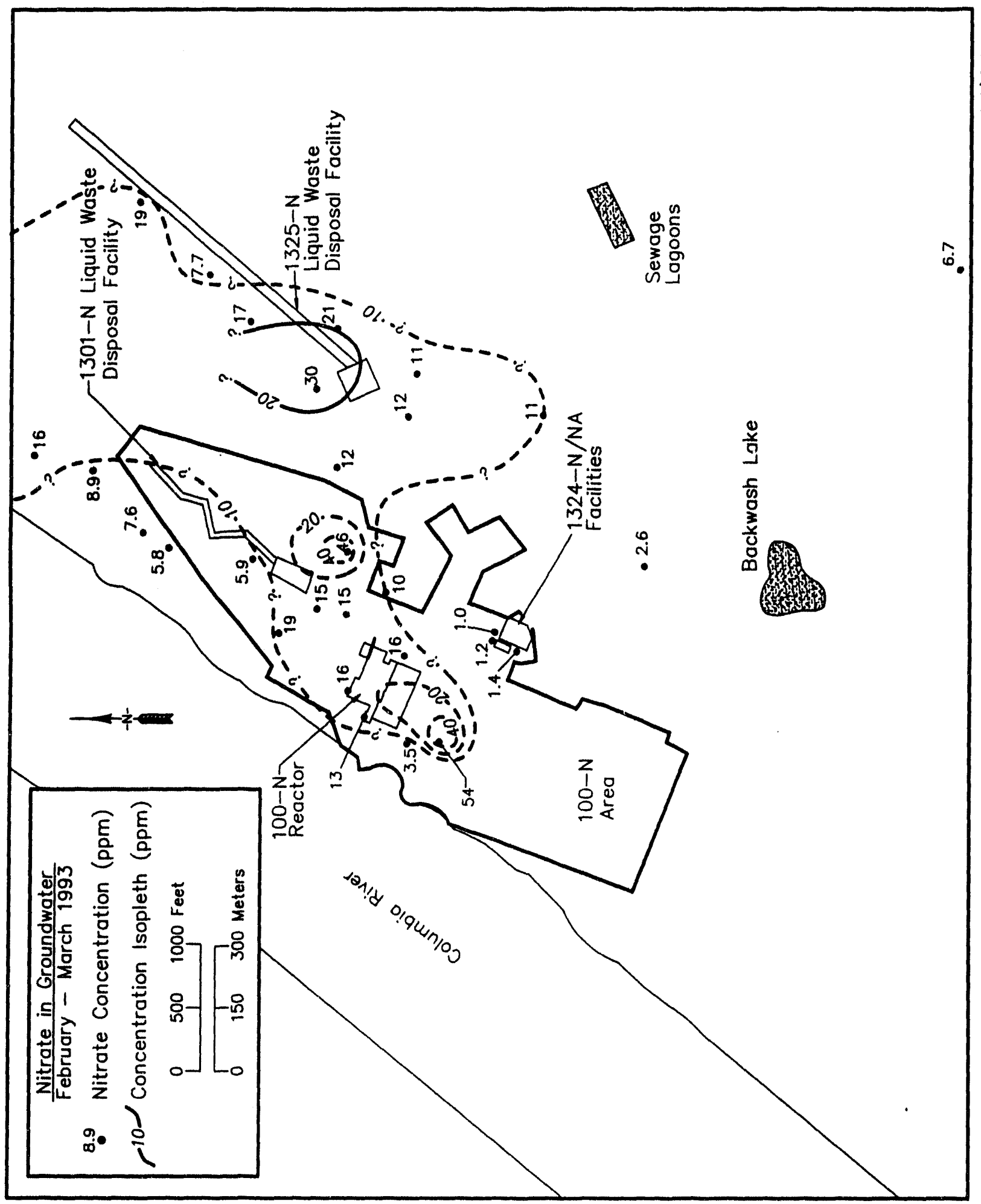


Sulfate concentrations ranged from 12,500 to $550,000 \mathrm{ppb}$. The site BTV for sulfate is around $90,500 \mathrm{ppb}$ (see Table 7). Of the 42 well samples, 33 have concentrations over $50,000 \mathrm{ppb}$. Fourteen of these wells have concentrations in the site BTV. There is a known sulfate plume in the 100-N Area from past-practice disposal activities. The 1325-N/NA Facility is the source of the sulfate in the 100-N Area. Eight of the high sulfate concentration wells also exceed the WWQS for slilfate, which is $250,000 \mathrm{ppb}$. These we1ls are $\mathrm{N}-17$ $(350,1100 \mathrm{ppb}), \mathrm{N}-21(520,000 \mathrm{ppb}), \mathrm{N}-23(400,000 \mathrm{ppb}), \mathrm{N}-25$ $(550,1100 \mathrm{ppb}), \mathrm{N}-47(440,000 \mathrm{ppb}), \mathrm{N}-54(270,000 \mathrm{ppb}), \mathrm{N}-56$ $(255,000 \mathrm{ppb})$, and $N-57(300,000 \mathrm{ppb})$ (see Figure 24). A plume map for sulfate is shown in Figure 36.

Phosphate concentrations were at or below the CRQL of $400 \mathrm{ppb}$ for all but one well in the 100-N Area. Well N-73 had a concentration of $500 \mathrm{ppb}$.

Bromide concentrations were at or less than the CRQL of $500 \mathrm{ppb}$ (see Table 7).

- Metal concentrations--Aluminum concentrations ranged from 53 to $8,300 \mathrm{ppb}$. All but two of the values were below the site BTV ( $<200 \mathrm{ppb}$ ) for the unconfined aquifer (see Table 7). The two wells that exceeded this value are $\mathrm{N}-57(8,300 \mathrm{ppb})$ and $\mathrm{N}-64(1,400 \mathrm{ppb})$. These wells are located fairly close to each other, south of the 1301-N LWDF (see Figure 24). The source of elevated aluminum values is unknown.

Arsenic concentrations ranged from 4 to $17 \mathrm{ppb}$. The site BTV for the unconfined aquifer is $10 \mathrm{ppb}$ (see Table 7). Three wells exceeded this value: $\mathrm{N}-34$ (13 ppb), $\mathrm{N}-57$ (17 ppb), and $\mathrm{N}-73$ $(13 \mathrm{ppb})$. The wells are not adjacent to each other and there is no source of arsenic identified (see Figure 24).

Barium concentrations ranged from 17 to $225 \mathrm{ppb}$. The site BTV for the unconfined aquifer is $69 \mathrm{ppb}$ (see Table 7). Six wells exceed this value: $\mathrm{N}-3$ (71 ppb), N-16 (170 ppb), N-54 (70 ppb), N-56 (100 ppb), N-57 (225 ppb), and $\mathrm{N}-64$ (123 ppb). None of the wells exceed the WWQS of 1,000 ppb. The wells that are elevated in barium are located south and east of the 1301-N LWDF (see Figure 24).

Boron concentrations are all well below the site BTV ( $<100 \mathrm{ppb})$ (see Table 7).

Chromium concentrations for unfiltered samples ranged from at or below the CRQL of 20 to $140 \mathrm{ppb}$. The site BTV for the unconfined aquifer is less than $30 \mathrm{ppb}$ (see Table 7). Ten wells exceed the site BTV: $\mathrm{N}-16$ (65 ppb), N-26 (65 ppb), N-34 (31 ppb), N-57

(95 ppb), N-64 (56 ppb), N-69 (38 ppb), N-71 (49 ppb), N-72 (34 ppb), N-73 (92 ppb), and N-74 (140 ppb) (see Figure 24). 


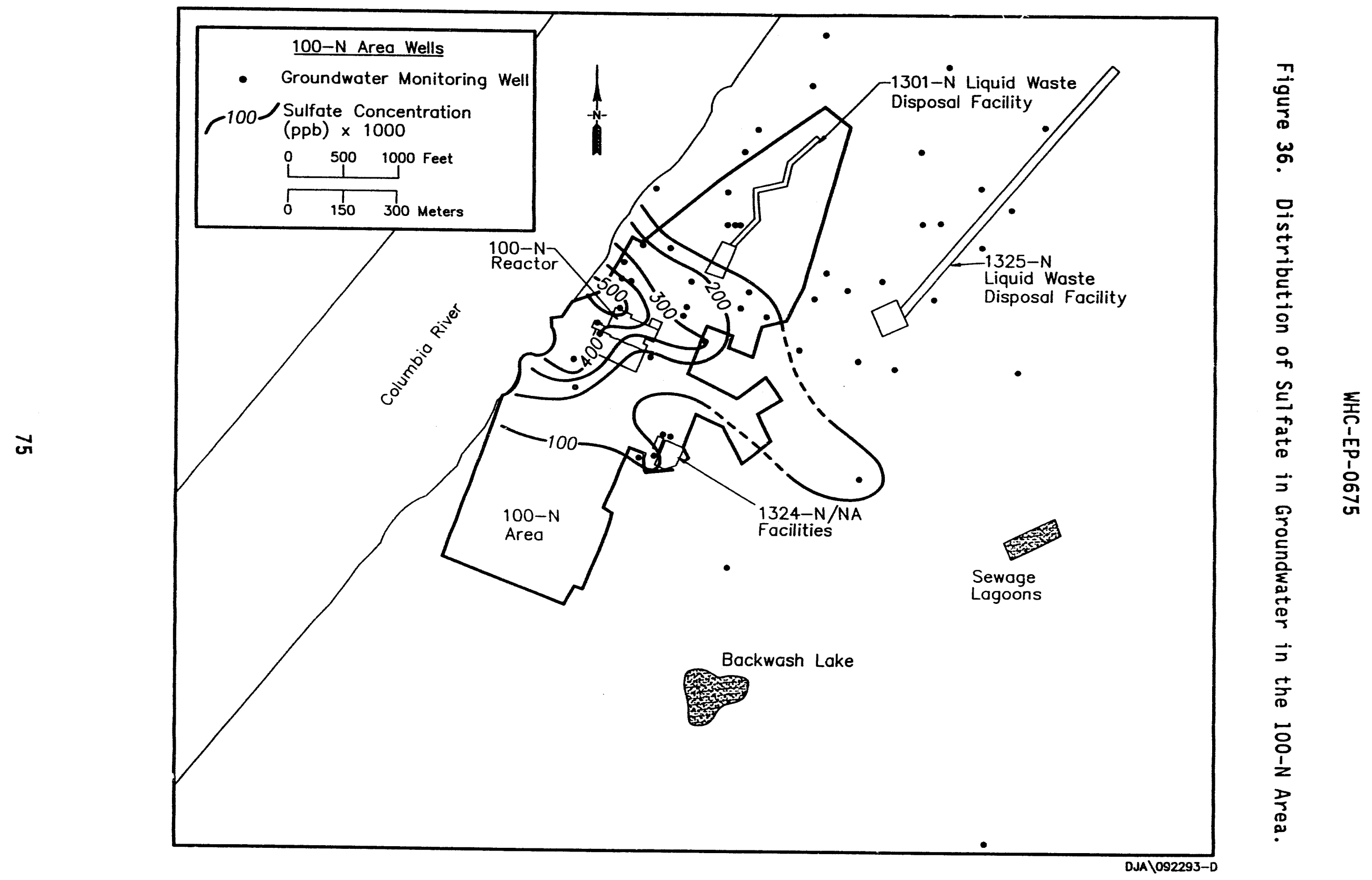


Filtered samples were all at or below the CRQL of $200 \mathrm{ppb}$. Six of the wells listed above exceed the WWQS for chromium, which is $50 \mathrm{ppb}$. There are chromium plumes in other 100 Areas, but none is identified in the 100-N Area presently. Elevated chromium concentrations in unfiltered samples from new wells may be attributed to fragments of stainless steel, produced during installation of well casings and screens.

Copper concentrations range from at or below the CRQL of 20 to $80 \mathrm{ppb}$. The site BTV concentration for the unconfined aquifer is less than $30 \mathrm{ppb}$ (see Table 7). Only one well exceeds this value, N-57 (80 ppb) (see Figure 24).

Iron concentrations ranged from at or below the CRQL of 20 to $45,020 \mathrm{ppb}$. The site BTV concentration for the unconfined aquifer is 86 to $818 \mathrm{ppb}$ (see Table 7). Nine wells in the 100-N Area exceed this value: $N-3(3,665 \mathrm{ppb}), \mathrm{N}-16(9,500 \mathrm{ppb}), \mathrm{N}-25(6,750 \mathrm{ppb})$, $\mathrm{N}-26(3,550 \mathrm{ppb}), \mathrm{N}-34(17,000 \mathrm{ppb}), \mathrm{N}-41$ (21,000 ppb), N-57 $(45,020 \mathrm{ppb}), \mathrm{N}-62(950 \mathrm{ppb})$, and $\mathrm{N}-64(7,433 \mathrm{ppb})$. The wells listed above, and the following wells all exceed the WWQS for iron, which is $300 \mathrm{ppb}$ : N-14 (375 ppb), N-23 (550 ppb), N-73 (560 ppb), and $\mathrm{N}-74$ (433 ppb) (see Figure 24). Filtered samples were all reduced in concentration compared to unfiltered samples. Iron concentrations can be elevated in unfiltered samples from new wells because of the influence of the stainless steel casing and well screen, or from iron precipitated on sediments pulled in through the well screen.

Lead concentrations were at or below the CRQL of $5 \mathrm{ppb}$, except for well $\mathrm{N}-57$, which had a concentration of $14 \mathrm{ppb}$ (see Figure 24). This value does not exceed the WWQS of $50 \mathrm{ppb}$.

Magnesium concentrations ranged from 370 to $23,000 \mathrm{ppb}$. The site BTV for the unconfined aquifer is $16,480 \mathrm{ppb}$ (see Table 7). Seven of the wells had values which exceeded this BTV: N-21 (23,000 ppb), $\mathrm{N}-23(17,000 \mathrm{ppb}), \mathrm{N}-25(22,000 \mathrm{ppb}), \mathrm{N}-47(20,000 \mathrm{ppb}), \mathrm{N}-56$ $(19,000 \mathrm{ppb}), \mathrm{N}-57(20,000 \mathrm{ppb})$, and $\mathrm{N}-64(16,667 \mathrm{ppb})$ (see Figure 24).

Manganese concentrations ranged from at or below the CRQL of 10 to $295 \mathrm{ppb}$. The site BTV for the unconfined aquifer is 25 to $164 \mathrm{ppb}$ (because of multiple populations of background manganese)

(see Table 7). Five wells exceed the ranges upper value: $\mathrm{N}-3$ (177 ppb), N-16 (295 ppb), N-34 (180 ppb), N-57 (290 ppb), and N-64 (170 ppb) (see Figure 24). The wells listed above, and the following wells all exceed the WWQS for manganese, which is 50 ppb: $\mathrm{N}-25$ (105 ppb), N-26 (70 ppb), and N-41 (100 ppb). Consentrations of filtered samples were lower than unfiltered sample concentrations.

Nickel concentrations ranged from at or below the CRQL of 30 to $93 \mathrm{ppb}$. The site BTV for the unconfined aquifer is less than $30 \mathrm{ppb}$ (see Table 7). Five wells exceed the BTV value: $N-57$ (55 ppb), $\mathrm{N}-64$ (93 ppb), N-71 (36 ppb), N-73 (42 ppb), and $\mathrm{N}-74$ (59 ppb) (see Figure 24). Only three of the wells listed above exceed the WWQS 
for nicke1, which is $50 \mathrm{ppb}$. Filtered samples were all at or below the CRQL. Nickel concentrations can be elevated in unfiltered samples from new wells because of the influence of the stainless steel casing and well screen.

Strontium (nonradiological) concentrations ranged from 79 to $426 \mathrm{ppb}$. The site BTV for the unconfined aquifer is $264 \mathrm{ppb}$ (see Table 7). Four wells exceed the BTV value: $\mathrm{N}-16$ (317 ppb), N-21 (318 ppb), N-47 (283 ppb), and N-55 (426 ppb) (see Figure 24). Filtered and unfiltered samples were in the same range of concentrations.

Vanadium concentrations ranged from 20 to $110 \mathrm{ppb}$. The site BTV for the unconfined aquifer is $15 \mathrm{ppb}$ (see Table 7). All the wells exceed this value. There is no WWQS for vanadium. The filtered samples were within a similar range of concentrations as the unfiltered samples, with the exception of well N-57 (see Figure 24). This well had a concentration of $110 \mathrm{ppb}$ unfiltered and $30 \mathrm{ppb}$ filtered. Most of the unfiltered samples were similar to this elevated unfiltered value. The cause of elevated vanadium concentrations in the groundwater at 100-N Area is unknown.

The following metals were equal or less than CRQLs: antimony (200 ppb), beryllium (3 ppb), cadmium (10 ppb), cobalt (20 ppb), lithium (10 ppb), molybdenum $(40 \mathrm{ppb})$, selenium (10 ppb), silver (20 ppb), thallium (5 ppb), tin (100 ppb), titanium $(60 \mathrm{ppb})$.

Mercury and uranium were not detected in the groundwater samples analyzed.

- Organic concentrations--Hydrazine concentrations all at or below CRQL of $30 \mathrm{ppb}$.

All other organics analyzed were at or less than the CRQL for each constituent.

- Radionuclide concentrations--Except for tritium and strontium-90, the radionuclide data are at or below the limit of quantification for the following constituents: antimony-125, cobalt-60, ruthenium-106, and cesium-137 (Tables 8, 9, 10, and 11, respectively).

Strontium-90 concentrations range from 0 to $1,120 \mathrm{pCi} / \mathrm{L}$. The values above background range from 36 to $1,120 \mathrm{pCi} / \mathrm{L}$ in the following wells: $\mathrm{N}-2$ (92 ppb), N-3 (706 ppb), N-14 (1,120 ppb), N-17 (220 ppb), N-27 (214 ppb), N-28 (112 ppb), N-29 (343 ppb), N-34 (55 ppb), N-54 (317 ppb), N-56 (227 ppb), and $\mathrm{N}-57$ (36 ppb). These wells are located downgradient of the 1301-N and 1325-N LWDFs (see Figure 24). There is a known plume of strontium-90 contamination in the 100-N Areas (Figure 37). The elevated concentrations of strontium-90 result from past-practice disposal operations at the $1301-N$ and the 1325-N LWDFs. 
Table 8. Antimony-125 Limit of Detection/Limit of Quantification Calculated from Field Blanks."

\begin{tabular}{|c|c|c|c|c|c|}
\hline $\begin{array}{c}\text { Time } \\
\text { period }\end{array}$ & $\begin{array}{c}\text { Number } \\
\text { of } \\
\text { blanks }\end{array}$ & $\begin{array}{c}\text { Blank } \\
\text { mean } \\
(p C i / L)\end{array}$ & $\begin{array}{c}\text { Blank } \\
\text { standard } \\
\text { deviation } \\
(p C i / L)\end{array}$ & $\begin{array}{c}L O D^{b} \\
(p C i / L)\end{array}$ & $\begin{array}{c}L O Q^{b} \\
(p C i / L)\end{array}$ \\
\hline $\begin{array}{c}01 / 02 / 92 \\
\text { to } \\
03 / 20 / 92\end{array}$ & 7 & 3.73 & 5.666 & 17.0 & 56.7 \\
\hline $\begin{array}{c}04 / 07 / 92 \\
\text { to } \\
06 / 11 / 92\end{array}$ & 5 & -4.57 & 5.526 & 16.6 & 55.3 \\
\hline $\begin{array}{c}07 / 02 / 92 \\
\text { to } \\
09 / 11 / 92\end{array}$ & 7 & 3.93 & 7.194 & 21.6 & 71.9 \\
\hline $\begin{array}{c}11 / 05 / 92 \\
\text { to } \\
11 / 10 / 92\end{array}$ & 2 & 10.00 & 5.664 & 17.0 & 56.6 \\
\hline $\begin{array}{c}01 / 02 / 92 \\
\text { to } \\
11 / 10 / 92\end{array}$ & 21 & 2.42 & 6.218 & 18.7 & 62.2 \\
\hline $\begin{array}{c}02 / 25 / 93 \\
\text { to } \\
05 / 11 / 93\end{array}$ & 5 & 5.66 & 14.433 & 43.3 & 144.3 \\
\hline
\end{tabular}

"The field blanks are QC samples that are introduced into a process to monitor the performance of the system. The calculated LOD/LOQ (using field blanks) measure the errors in the entire measurement system.

LOD is 3 times blank standard deviation. $L O Q$ is 10 times blank standard deviation.

$\angle O D=1$ imit of detection.

$L O Q=1$ imit of quantification.

$Q C=$ quality control. 
Table 9. Cobalt-60 Limit of Detection/Limit of Quantification Calculated from Field $B 1$ anks.

\begin{tabular}{|c|c|c|c|c|c|}
\hline $\begin{array}{c}\text { Time } \\
\text { period }\end{array}$ & $\begin{array}{l}\text { Number } \\
\text { of } \\
\text { blanks }\end{array}$ & $\begin{array}{c}\text { Bl ank } \\
\text { mean } \\
(p C i / L)\end{array}$ & $\begin{array}{c}\text { Blank } \\
\text { standard } \\
\text { deviation } \\
(\mathrm{pCi} / \mathrm{L}) \\
\end{array}$ & $\begin{array}{c}L O D^{b} \\
(p C i / L)\end{array}$ & $\begin{array}{c}\angle O Q^{b} \\
(P C i / L)\end{array}$ \\
\hline $\begin{array}{c}01 / 02 / 92 \\
\text { to } \\
03 / 20 / 92 \\
\end{array}$ & 7 & 1.796 & 4.943 & 14.8 & 49.4 \\
\hline $\begin{array}{c}04 / 07 / 92 \\
\text { to } \\
06 / 11 / 92 \\
\end{array}$ & 5 & 0.060 & 3.840 & 11.5 & 38.4 \\
\hline $\begin{array}{c}07 / 02 / 92 \\
\text { to } \\
09 / 11 / 92 \\
\end{array}$ & 7 & 1.399 & 3.288 & 9.9 & 32.9 \\
\hline $\begin{array}{c}11 / 05 / 92 \\
\text { to } \\
11 / 10 / 92 \\
\end{array}$ & 2 & -5.730 & 3.521 & 10.6 & 35.2 \\
\hline $\begin{array}{c}01 / 02 / 92 \\
\text { to } \\
11 / 10 / 92 \\
\end{array}$ & 21 & 0.533 & 4.079 & 12.2 & 40.8 \\
\hline $\begin{array}{c}02 / 05 / 93 \\
\text { to } \\
05 / 11 / 93 \\
\end{array}$ & 5 & -1.614 & 4.515 & 13.5 & 45.2 \\
\hline
\end{tabular}

The field blanks are $Q C$ samples that are introduced into a process to monitor the performance of the system. The calculated LOD/LOQ (using field blanks) measure the errors in the entire measurement system. LOD (limit of detection) is 3 times blank standard deviation. LOQ (1 imit of quantification) is 10 times blank standard deviation. $L O D=1$ imit of detection.

$L O Q=$ limit of quantification. 
Table 10. Ruthenium-106 Limit of Detection/Limit of Quantification Calculated from Field Blanks."

\begin{tabular}{|c|c|c|c|c|c|}
\hline $\begin{array}{c}\text { Time } \\
\text { period }\end{array}$ & $\begin{array}{c}\text { Number } \\
\text { of } \\
\text { blanks }\end{array}$ & $\begin{array}{c}\text { Blank } \\
\text { mean } \\
(\mathrm{PC} 1 / L)\end{array}$ & $\begin{array}{c}\text { Blank } \\
\text { standard } \\
\text { deviation } \\
(\mathrm{pC} / / \mathrm{L})\end{array}$ & $\begin{array}{c}L O D^{b} \\
(p C i / L)\end{array}$ & $\begin{array}{c}\angle O Q^{b} \\
\left(\mathrm{pC}^{b} / L\right)\end{array}$ \\
\hline $\begin{array}{c}1 / 02 / 92 \\
\text { to } \\
03 / 20 / 92\end{array}$ & 7 & 12.24 & 20.641 & 61.9 & 206.4 \\
\hline $\begin{array}{c}04 / 07 / 92 \\
\text { to } \\
06 / 11 / 92\end{array}$ & 5 & 2.10 & 36.288 & 108.9 & 362.9 \\
\hline $\begin{array}{c}07 / 02 / 92 \\
\text { to } \\
09 / 11 / 92\end{array}$ & 7 & -8.29 & 22.853 & 68.6 & 228.5 \\
\hline $\begin{array}{c}11 / 05 / 92 \\
\text { to } \\
11 / 10 / 92\end{array}$ & 2 & -20.30 & 8.202 & 24.6 & 82.0 \\
\hline $\begin{array}{c}01 / 02 / 92 \\
\text { to } \\
11 / 10 / 92 \\
\end{array}$ & 21 & -0.12 & 25.465 & 76.4 & 254.6 \\
\hline $\begin{array}{c}02 / 25 / 93 \\
\text { to } \\
05 / 11 / 93\end{array}$ & 5 & 1.82 & 30.018 & 114.1 & 380.2 \\
\hline
\end{tabular}

-The field blanks are QC samples that are introduced into a process to monitor the performance of the system. The calculated LOD/LOQ (using field blanks) measure the errors in the entire measurement system.

LOD is 3 times blank standard deviation. LOQ is 10 times blank standard deviation.

$L O D=1$ imit of detection.

$L O Q=$ limit of quantification.

$Q C=$ quality control. 
Table 11. Cesium-137 Limit of Detection/Limit of Quantification Calculated from Field Blanks. ${ }^{\circ}$

\begin{tabular}{|c|c|c|c|c|c|}
\hline $\begin{array}{c}\text { Time } \\
\text { period }\end{array}$ & $\begin{array}{l}\text { Number } \\
\text { of } \\
\text { blanks }\end{array}$ & $\begin{array}{c}\text { Blank } \\
\operatorname{mean} \\
(p C i / L)\end{array}$ & $\begin{array}{c}\text { Blank } \\
\text { standard } \\
\text { deviation } \\
(\mathrm{PC} \mathrm{I} / \mathrm{L})\end{array}$ & $\begin{array}{c}L O D^{b} \\
(P C i / L)\end{array}$ & $\begin{array}{c}\angle O Q^{b} \\
\left(p C^{\prime} T / L\right)\end{array}$ \\
\hline $\begin{array}{c}01 / 02 / 92 \\
\text { to } \\
03 / 20 / 92\end{array}$ & 7 & -3.992 & 2.943 & 8.8 & 29.4 \\
\hline $\begin{array}{c}04 / 07 / 92 \\
\text { to } \\
06 / 11 / 92\end{array}$ & 5 & -0.987 & 4.857 & 14.6 & 48.6 \\
\hline $\begin{array}{c}07 / 02 / 92 \\
\text { to } \\
09 / 11 / 92\end{array}$ & 7 & 1.149 & 3.382 & 10.1 & 33.8 \\
\hline $\begin{array}{c}11 / 05 / 92 \\
\text { to } \\
11 / 10 / 92 \\
\end{array}$ & 2 & 1.866 & 2.269 & 6.8 & 22.7 \\
\hline $\begin{array}{c}01 / 02 / 92 \\
\text { to } \\
11 / 10 / 92\end{array}$ & 21 & -1.01 & 3.598 & 10.8 & 36.0 \\
\hline $\begin{array}{c}02 / 25 / 93 \\
\text { to } \\
05 / 11 / 93\end{array}$ & 5 & -1.43 & 1.728 & 5.2 & 17.3 \\
\hline
\end{tabular}

"The field blanks are $Q C$ samples that are introduced into a process to monitor the performance of the system. The calculated LOD/LOQ (using field blanks) measure the errors in the entire measurement system.

LOD is 3 times blank standard deviation. $L O Q$ is 10 times blank standard deviation.

$\angle O D=$ limit of detection.

$L O Q=1$ imit of quantification.

$Q C=$ quality control. 


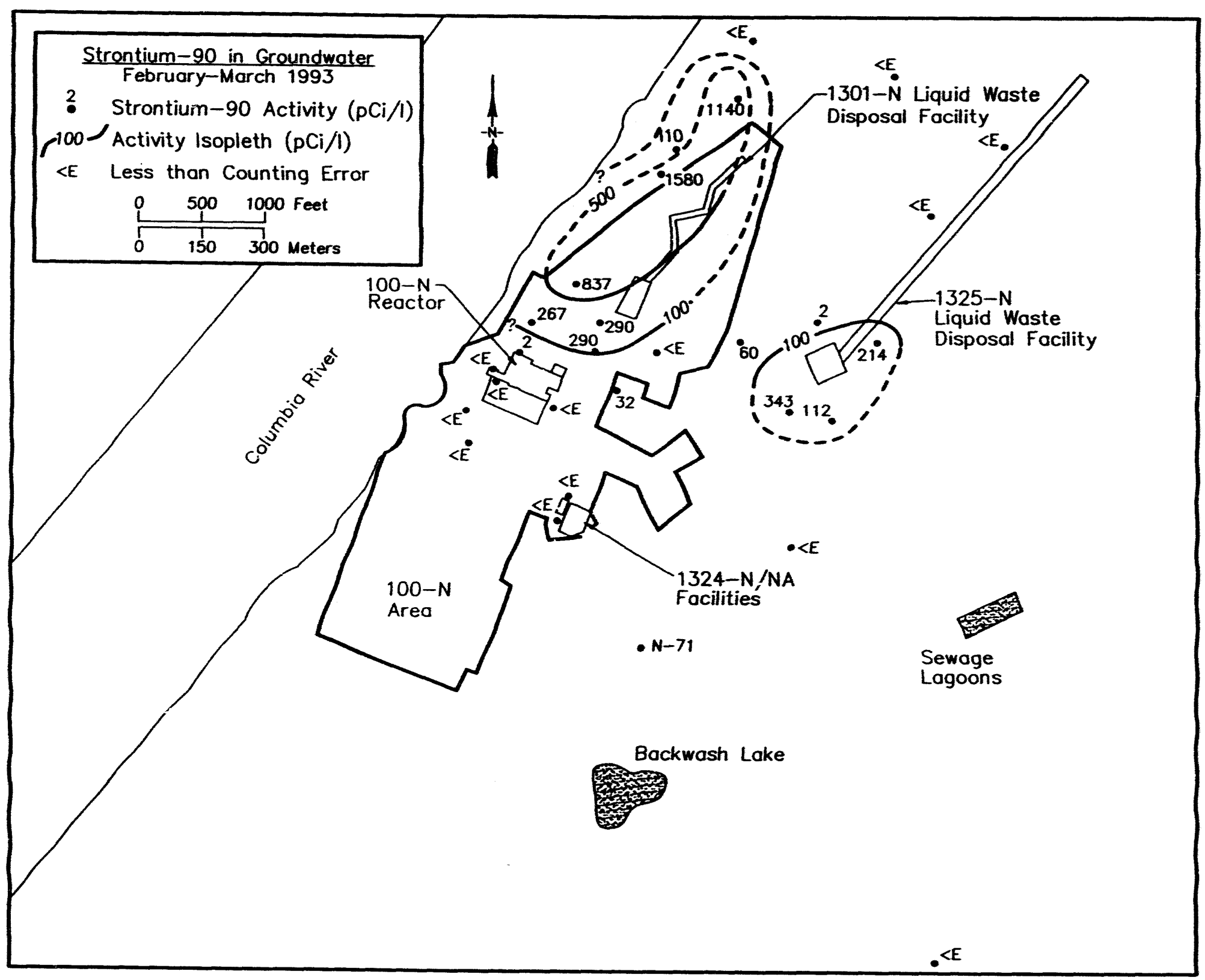

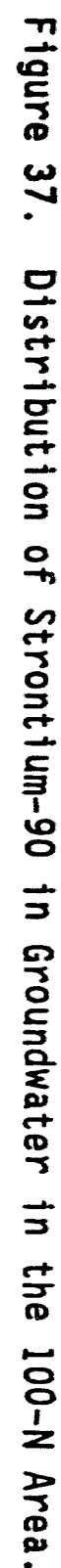




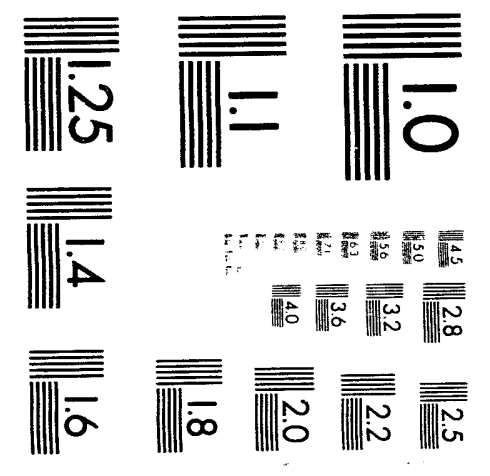



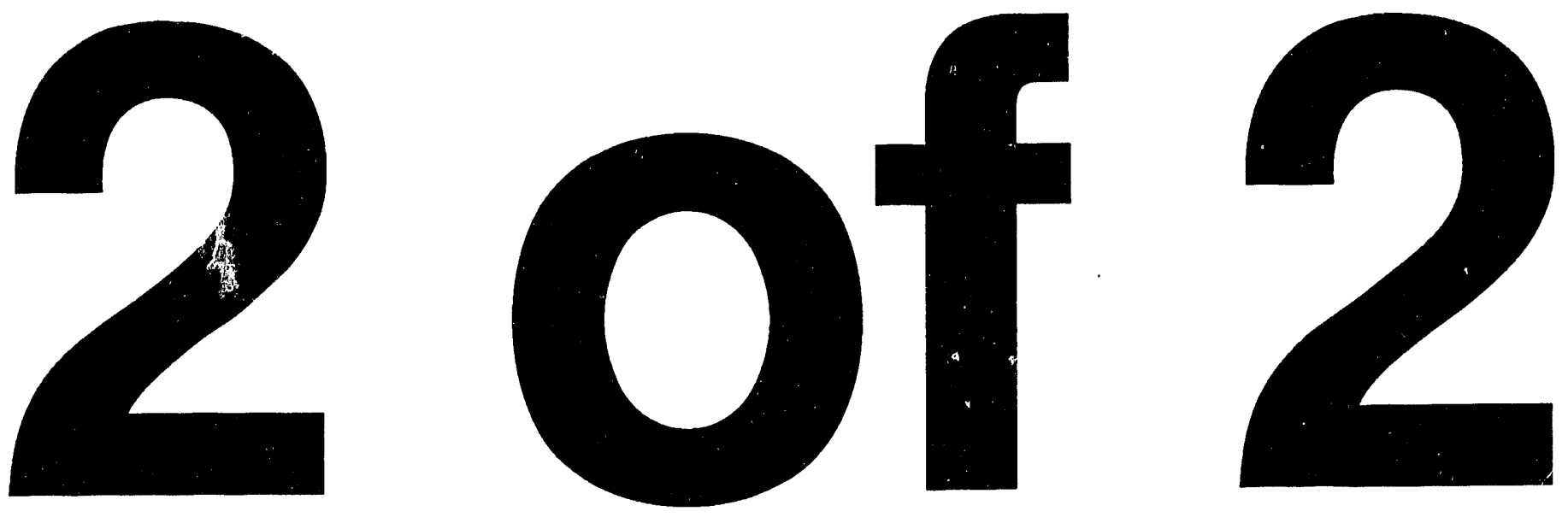
Tritium concentrations range from 39 to $78,600 \mathrm{pCi} / \mathrm{L}$. All but one value is above $100 \mathrm{pCi} / \mathrm{L}$. The wells located downgradient of the 1301-N and 1325-N LWDFs have the highest concentrations of tritium (see Figure 24). Varying concentrations of tritium are detected in all the wells. There is a known plume of tritium contamination in the 100-N Areas (Figure 38). The elevated concentrations of tritium are caused by past-practice disposal operations at the 1301-N and 1325-N LWDFs.

\subsection{SOIL COLUMN AND AQUIFER SEDIMENT CHEMICAL FACTORS}

\subsubsection{Soil Factors}

The soil column or vadose zone beneath the 1325-N LWDF is composed of predominately sands and gravels, with minor fine-grained sediments (silts and loess). Sediments in the $100-\mathrm{N}$ Area also contain 0.5 to $1.6 \% \mathrm{CaCO}_{3}$ (Hartman 1992). During disposal to the 1325-N LWDF, the sample analytical data indicated that effluent discharges contained numerous radionuclides in concentrations which, in most cases, greatly exceeded $1 / 25$ th of the derived concentration guides (Group A study guideline concentrations [WHC 1990a]). While concentrations of these constituents have decreased since the $N$ Reactor was placed in dry layup, concentrations of some radioactive constituents remain high as a result of residual contamination in the soil column. Tritium and strontium-90 radionuclides have travelled through the soil column to the water table, and contaminated plumes have resulted. Chemical contaminants include chloride, sodium, calcium, strontium, nitrate, and sulfate. In addition, there appears to be elevated concentrations of metals in the groundwater, including iron, magnesium, chromium, and vanadium.

To estimate contaminant migration rates, the wastewater discharged to the crib is characterized as neutral to basic ( $\mathrm{pH}=7.8$ ) and is $10 \mathrm{w}$ in both organic and inorganic constituents. Under these conditions, most of the cationic constituents tend to be immobile (e.g., calculated migration rates on the order of 1 to $3 \mathrm{~cm} /$ day). Tritium and the anionic constituents (iodine-131 and ruthenium-106 are treated as nonsorbing, for which a migration rate equivalent to water is assumed (approximately $360 \mathrm{~cm} /$ day [142 in./day] (WHC 1990a).

\subsubsection{Aquifer Sediment Factors}

The water softener regenerant from the 1324-N/NA Facility may have an effect on strontium-90 mobility and transport because of competing ion effects. This effect involves several competing divalent cations, caused by the presence of several alkali and alkali-earth metals removed from river water in the water softener process, and then discharged with the regenerant. The most common competing ion is $\mathrm{Ca}^{2+}$, but other divalent cations will also compete with strontium-90 to a less degree (Cantrell and Serne 1993, see Appendix A). 


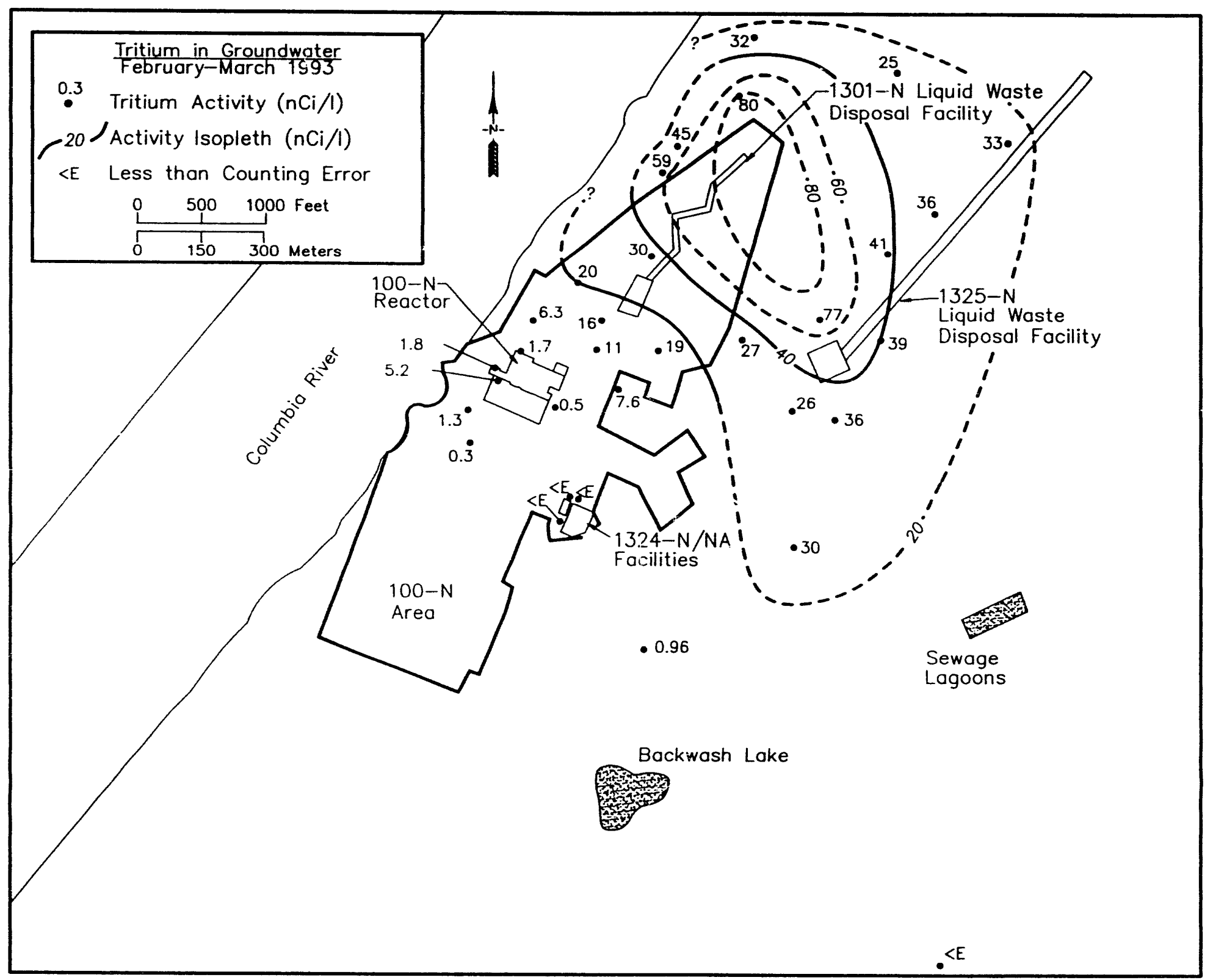

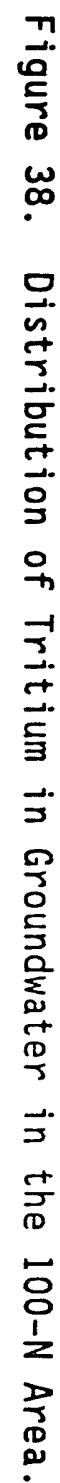


WHC-EP-0675

\subsection{SUMMARY OF CONCEPTUAL MODEL OF MOISTURE MOVEMENT AND CONTAMINANT TRANSPORT}

A conceptual model of the hypothetical impact of occasional slug releases to the 1325-N Crib is summarized as follows (Figure 39):

(1) The principal contaminanis of concern are the long-1ived radionuclides strontium-93 and cesium-137, which were added to the crib at the rate of approximately $1 \mathrm{Ci} /$ month during the 5-year period of use (1983 to 1988).

(2) The centroid of the strontium-90 and cesium-137 radionuclide inventory (approximately $60 \mathrm{Ci}$ each, assuming no decay) reaches the water table near the end of the operating period.

(3) A (327,059-L [86,400-gal]) slug release of 1 month's accumulation at $8 \mathrm{~L} / \mathrm{min}$ ( $2 \mathrm{gal} / \mathrm{min}$ ) is discharged as a random event. Contaminants in the spent emergency water are assumed to be insignificant in comparison to the inventory already in the soil column beneath the crib. The spent emergency water is assumed to have a chemical composition similar to river water (low salt content; slightly basic $\mathrm{pH}$; no surfactants, detergents, or complexants).

(4) The soil beneath the crib has been previously wetted, so there is very little additional holding capacity for retention of the hypothetical slug release. The slug release displaces $327,059 \mathrm{~L}$ $(86,400 \mathrm{gal})$ of water from pore fluid in the soil column assumed to be in equilibrium with the adsorbed strontium-90 and cesium-137.

(5) The displaced pore volume and associated strontium-90 and cesium-137 enters the unconfined aquifer, undergoing dilution and dispersion as it slowly migrates toward the river.

(6) The strontium-90 migrates more rapidly than the cesium-137 because of interaction with water softener regenerant chemicals from an adjacent past-practice disposal facility.

The contaminant transport and $r$ lease scenario summarized above is evaluated in the following section using previous transport model calculations, results of laboratory sorption-desorption studies, and calculation of theoretical pore fluid radionuclide concentrations in the soil column beneath the crib. This model of contaminant migration through the vadose zone is considered conservative because:

- A piston-like displacement of pore fluid is assumed

- The water table has dropped $6 \mathrm{~m}(20 \mathrm{ft})$ since breakthrough of the strontium-90 became apparent. 


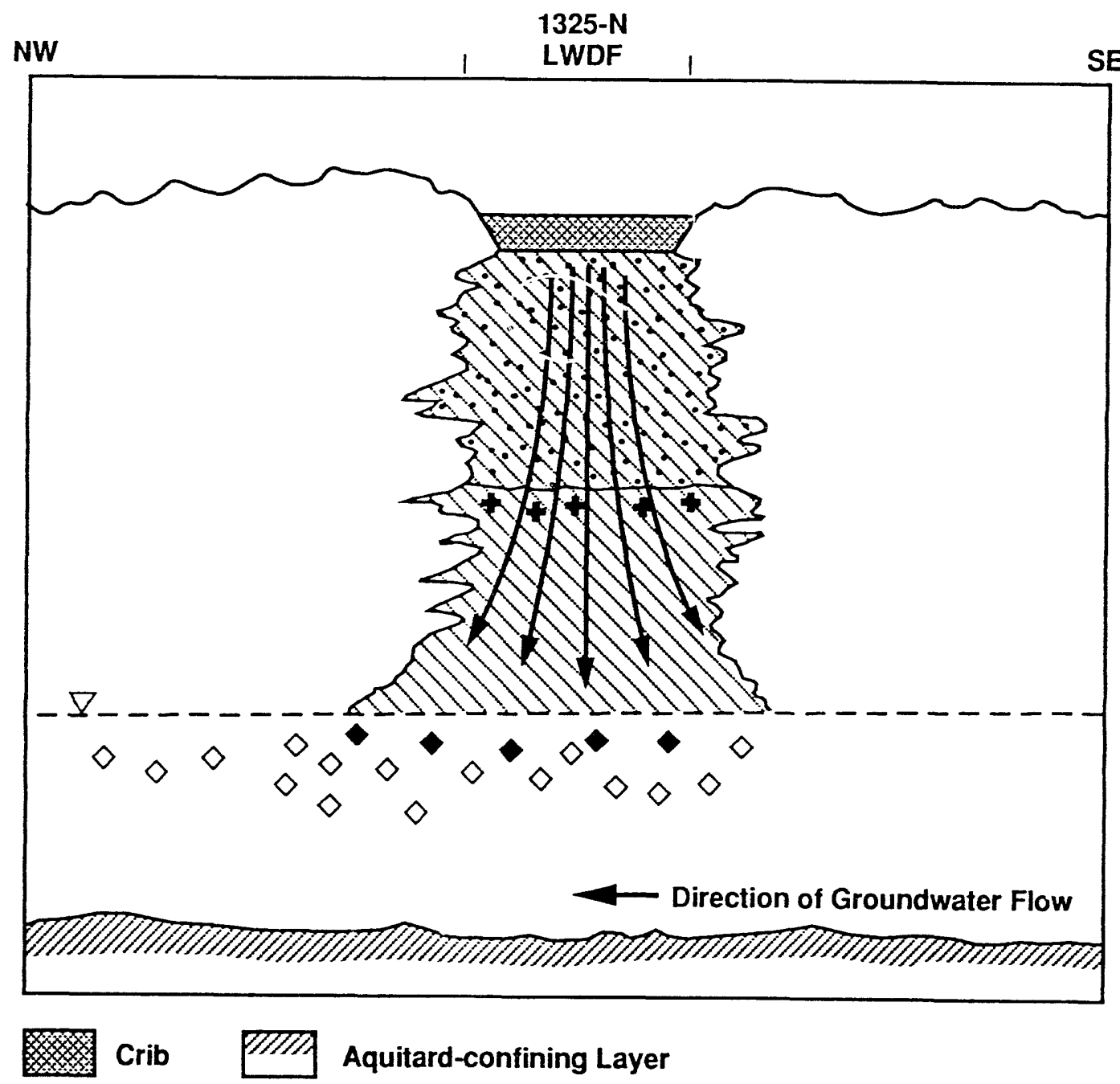

Initial Conditions

Just after facility was placed in dry-layup

status.

Contaminants adsorbed

on soil column:

\section{$\because \because$ Cesium-137}

$\triangle 1$ Strontium-90

Contaminants in pore fluid:

$\diamond$ Strontium-90

Conditions After Single Emergency Discharge

Slug release of 86,400 gals $(327,059 \mathrm{~L})$ to crib.

Contaminants in solution:

- Strontium-90

+ Cesium-137 


\subsection{IMPACT ASSESSMENT}

As required by the methodology document (Tyler 1991), both hydraulic and contaminant impacts are considered for each groundwater impact assessment. Accordingly, hydraulic factors relevant to the current status of the disposal facility are discussed first followed by contaminant transport analysis.

\subsection{HYDRAULIC CONSIDERATIONS}

The primary hydraulic considerations for evaluation of the conceptual model include discharge volume, moisture status of the soil column, and possible effects of multiple batch releases as discussed in the following sections.

\subsubsection{Slug Discharge Volume}

If there is an emergency, discharge of associated water is limited by Tri-Party Agreement Milestone M-17-15A. Under these restrictions, the discharge cannot exceed $327,059 \mathrm{~L}(86,400 \mathrm{gal})$ for a given calendar month (see Section 3.3).

\subsubsection{Moisture Status of Soil Column}

The 1325-N LWDF Crib was previously wetted (saturated flow). Wastewater has also overflowed the crib and into the first section of the trench. While the prior "wetting" of the soil column reduces the retention capacity for subsequent batch releases, current conditions may have improved this situation. The facility has not been used since April 1991, and before that time, received greatly reduced amounts of effluent. For the last 27 months, the soil column beneath the crib has been "drying out" or dewatering because of drainage and evaporation. In addition, the dramatic drop in the water table under the 100-N Area (over $6 \mathrm{~m}[20 \mathrm{ft}]$ ) and dissipation of the mound under 1325-N since 1990, increases the thickness of the unsaturated zone beneath the crib. This provides an additional buffer zone between the current water table elevation and the contaminated sediments above the water table.

\subsubsection{Response to Multiple Releases}

The infiltration area of the $1325-\mathrm{N}$ Crib is $5,574 \mathrm{~m}^{2}\left(60,000 \mathrm{ft}^{2}\right)$; discharging $327,059 \mathrm{~L}(86,400 \mathrm{gal})$ to the crib over a 30 -day period would only serve to rewet but not saturate the soil column. If the discharges resume on a consistent basis or more than one "emergency" occurs (multiple batch discharyes), then transport of pore fluid and associated contaminants down to the water table could occur. (The potential magnitude of the latter effect is estimated in Section 5.2.2.) 


\section{WHC-EP-0675}

\subsection{CONTAMINANT IMPACTS}

Evaluation of potential impacts of slug releases on groundwater quality in the vicinity of the crib requires:

- Prediction of the status of the radionuclide inventory on the soil column

- Calculation of the equilibrium pore fluid radionuclide concentrations.

A one-dimensional model is used to assess the depth of migration of contaminants in the soil column as described in Section 5.2.1. Pore fluid concentrations are estimated in Section 5.2.2.

\subsubsection{One-Dimensional Flow and Transport Analysis (Analytical Methods)}

The same one-dimensional analytical method described in the Liquid Effluent Study Final Project Report (WHC 1990a) was employed to estimate the rate of moisture and contaminant movement through the soil column beneath the crib during the operational period (1983-1988). The method considers only flow in the vertical direction and does not allow for lateral spreading. Thus it is expected to provide migration rates that are faster than those that occur under actual conditions.

The method is based on steady-state flow conditions in the unsaturated zone and assumes a unit hydraulic gradient. The basic equation for any layer of sediments is

$$
t=L \times \theta / q
$$

where:

$t=$ time of travel through layer, seconds

$L=$ thickness of layer, centimeters

$\theta=$ moisture content of sediment, related to hydraulic conductivity

$q=$ Darcy velocity or moisture flux in layer, centimeters/seconds.

The total travel time, $T$, is determined as the summation of the travel times for each of the " $i$ " layers:

$$
T=\Sigma L_{i=1}^{n} x \theta_{i} / q_{i}
$$


where $n$ is the rumber of sediment layers. For transport calculation purposes, the soil column beneath the crib is treated as a single layer of coarse sand and gravel with a depth to water of approximately $20 \mathrm{~m}$ (66 ft) (Figure 40).

The relationship between hydraulic conductivity, $K$, and moisture content, $\theta$, is described graphically in Figure 41 . These curves were derived empirically from laboratory tests on over 20 different Hanford Site sediment types, and were used to establish 5 major sediment types, as noted in Figure 41.

The one-dimensional flow analysis embodied in equation 2 was carried out on a Symphony spreadsheet. The total travel time, T, obtained with equation 2 is divided into the vadose zone thickness to provide an estimate of the rate of moisture migration from the disposal facility to the groundwater.

To obtain an estimate of the rate of contaminait migration, the retardation factor, $R_{f}$, for each of the contaminants identified was estimated from the following approximation for Hanford Site soils:

$$
R_{f}=1+5 K_{d}
$$

The $K_{d}$ values were selected from Ames and Serne (1991). When the rate of moisture migration is divided by the $R_{f}$ for the contaminant of interest, the result is an estimate of the contaminant migration rate. These computations were also carried out using the symphony spreadsheet method.

The effluent discharge rate, as described previously, is entered as liters per month in the spreadsheet computational method. Effluent volumes through 1987 listed in WHC-EP-0287, Vo1. 3, were updated to include 1988 and 1989 (WHC 1989b) for the Liquid Effluent Study Final Pioject Report

(WHC 1990a; the same average infiltration rate was also assumed for the time period subsequent to 1989). The total volume (1iters) was divided by the corresponding operating period (months) to establish an average rate of inflow (L/month). This effluent discharge rate was divided by the crib area to obtain an estimate of the average infiltration rate.

More details and an illustrative example for application of the overall computational approach are provided in WHC (1990a).

\subsubsection{Results of Analytical Solution for Operational Period}

(The following discussion summarizes the results from the Liquid Effluent Study Final Project Report [WHC 1990a]).

\footnotetext{
'Symphony is a registered trademark of the Lotus Development Corporation.
} 
Figure 40. Lithology of Well 199-N-70 Near the 1325-N Crib.

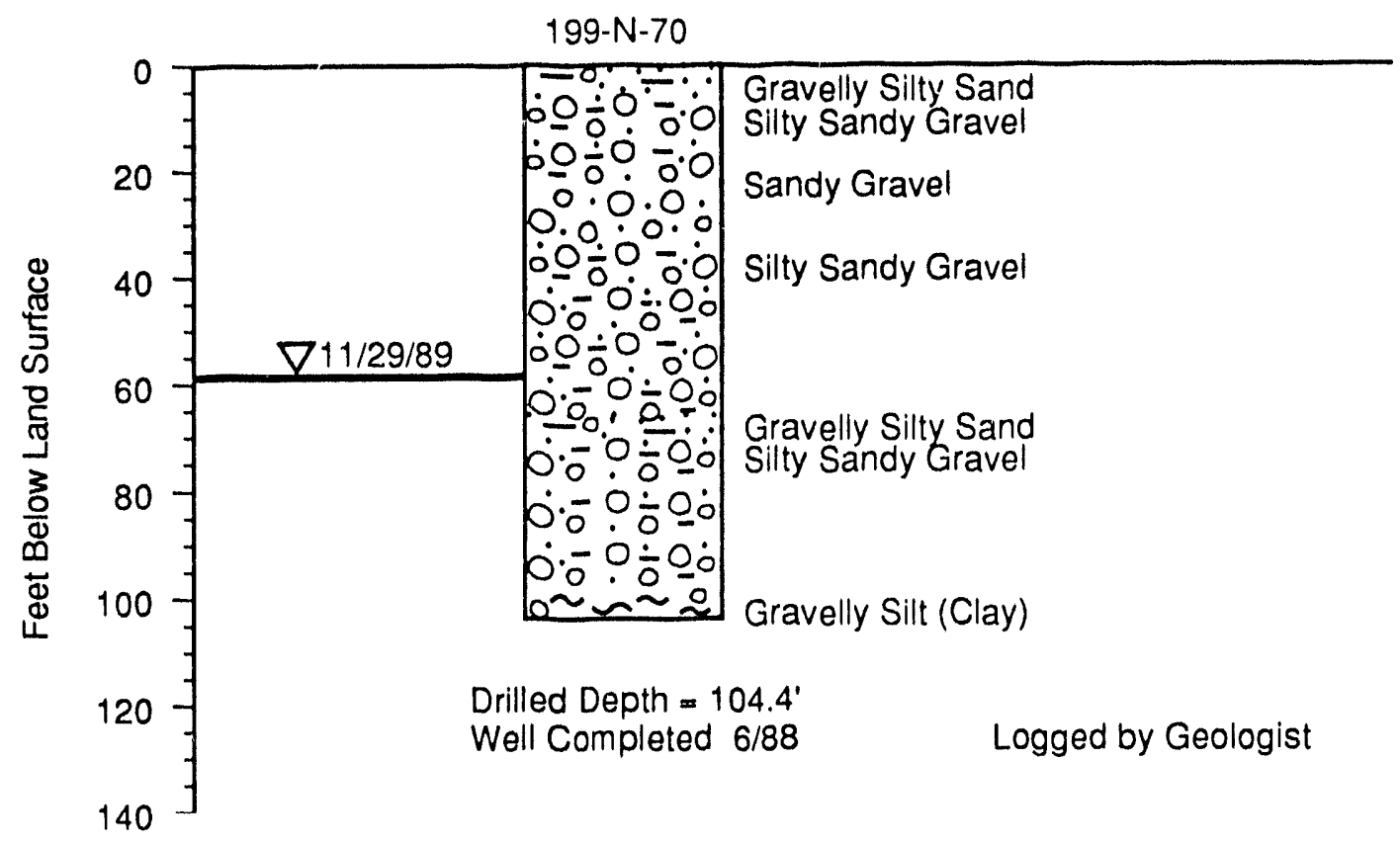

$\$ 9007025.3$ 
Figure 41. Hydraulic Conductivity Versus Moisture Content (WHC 1990a).

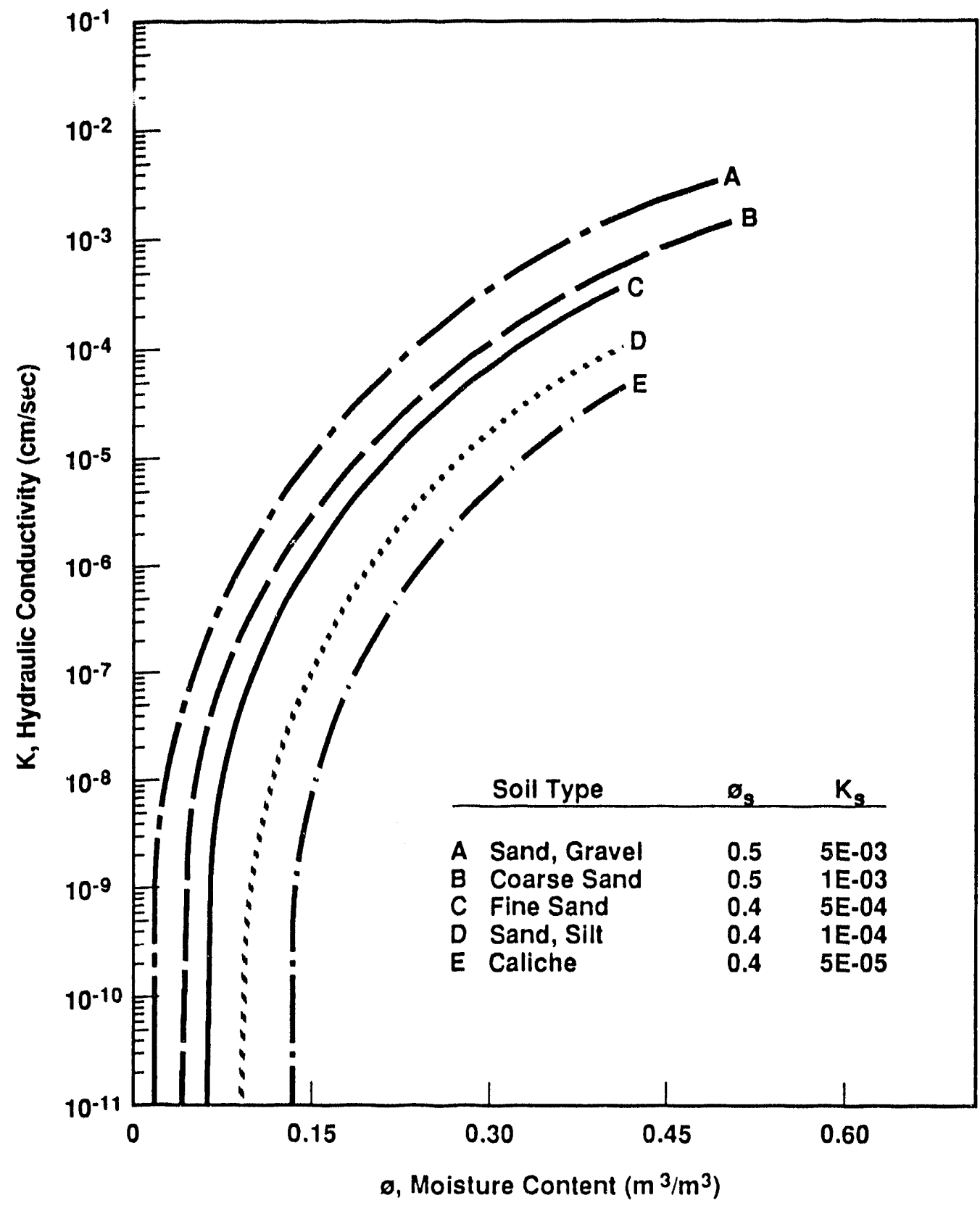

H9309026.5 
Based on general effluent characteristics and corresponding sorption parameters (Section 5.2.1) for the key constituents identified in Table 12, the calculated migration rates in the vadose zone (Table 13), listed most mobile to least mobile as follows:

- $153 \mathrm{~cm} /$ day (60 in./day) for tritium, antimony-124, antimony-125, and iodine-131

- $2 \mathrm{~cm} /$ day (0.8 in./day) for ruthenium-103 and ruthenium-106

- $1 \mathrm{~cm} /$ day (0.4 in./day) for plutonium-238, plutonium-239, zinc-65, strontium-89, strontium-90, zirconium-95, niobium-95, molybdenum-99, and barium-140

- $0.6 \mathrm{~cm} /$ day $(0.2 \mathrm{in./day)}$ for iron, phosphorus-32, manganese-54, cobalt-58, iron-59, cobalt-60, cesium-134, and cesium-137

- $0.2 \mathrm{~cm} /$ day (0.08 in./day) for lanthanum-140, cerium-141, and cerium-144.

The most significant constituents based on inventory, half-life, and relative hazard potential are strontium-90 and cesium-137. Based on the migration rates for these constituents (see Table 13) and above, breakthrough of strontium-90 should have occurred approximately 2 years before shutdown of $\mathrm{N}$ Reactor while cesium-137 (travel time of 7 years) should still be retained in the soil column. The presence of strontium-90 and the absence of cesium-137 in groundwater in the immediate vicinity of the crib (Section 4.3 ) are consistent with the corresponding migration rate estimates noted above.

\subsubsection{Soil Column Pore Fluid Strontium-90 Concentrations}

\subsubsection{Single Emergency Slug Release. As suggested in Section 4.5,} displacement of residual water in the soil pore spaces that has been in equilibrium with adsorbed strontium-90 is one potential pathway for groundwater contamination from occasional emergency water releases to the crib. To estimate this concentration we make use of the definition of $K_{d}$ :

$$
K_{d}=\frac{C_{s}, p C i / g}{C_{w}, p C i / m L}
$$

where:

$C_{s}=$ the equilibrium concentration of strontium-90 in the solid phase

$C_{w}=$ the concentration in the aqueous phase in a sediment-water mixture from batch laboratory sorption tests. 


\begin{tabular}{|c|c|c|c|c|c|c|}
\hline $\begin{array}{c}\text { Key } \\
\text { const ituents }\end{array}$ & Detection limit $^{a}$ & $\begin{array}{l}\text { Detection/ } \\
\text { analyses }\end{array}$ & $\begin{array}{c}\text { Sample } \\
\text { concentration } \\
(90 \% \mathrm{CI})\end{array}$ & Detection lirit ${ }^{a}$ & $\begin{array}{l}\text { Detection/ } \\
\text { analyses }\end{array}$ & $\begin{array}{c}\text { Sample } \\
\text { concentration } \\
(90 \% \mathrm{CI})\end{array}$ \\
\hline \multicolumn{4}{|c|}{$03 / 88$ to $08 / 88$, During cold standby } & \multicolumn{3}{|c|}{$10 / 89$ to $03 / 90$, During cold standby } \\
\hline Iron & 30 & $4 / 4$ & 420 & 30 & $4 / 4$ & $296^{b}$ \\
\hline \multicolumn{4}{|c|}{1976 to 1988 , During reactor operation ${ }^{c}$} & \multicolumn{3}{|c|}{$10 / 89$ to $03 / 90$, During cold standby } \\
\hline Tritium & 1,000 & $206 / \mathrm{NA}$ & 110,000 & 100 & $3 / 3$ & 198,000 \\
\hline Manganese-54 & 10 & $231 / \mathrm{NA}$ & 64,000 & NA & $3 / 3$ & $604^{6}$ \\
\hline Iron-59 & 10 & $86 / N A$ & 22,000 & NA & ND & ND \\
\hline Cobalt -60 & 10 & $236 / N A$ & 41,000 & 1 & $3 / 3$ & 700 \\
\hline 2 inc -65 & 100 & $12 / N A$ & 2,500 & NA & ND & ND \\
\hline Stront ium- 89 & 100 & $121 / \mathrm{NA}$ & 74,000 & NA & ND & ND \\
\hline Stront ium-90 & 200 & 205/NA & 33,000 & 0.1 & $2 / 2$ & 176,000 \\
\hline Ruthenium- 106 & 100 & 9/NA & 31,000 & 50 & $1 / 2$ & 1,720 \\
\hline Iodine- 131 & 100 & 91/NA & 160,000 & NA & ND & ND \\
\hline Ces ium- 134 & 10 & $96 / N A$ & 1.500 & NA & $2 / 2$ & 167 \\
\hline Cesium- 137 & 10 & 236/NA & 42,000 & 1 & $3 / 3$ & 47.000 \\
\hline Lanthanum- 140 & 10 & $102 / \mathrm{NA}$ & 910,000 & 0.001 & ND & ND \\
\hline Plutonium-239 & 0.1 & 206/NA & 420 & NA & $3 / 3$ & 66 \\
\hline Americium-241 & 20 & ND & ND & NA & $3 / 3$ & 70 \\
\hline Phosphorus - 32 & NA & 136/NA & 4,500 & NA & ND & ND \\
\hline Cobalt -58 & NA & 16/NA & 3,000 & NA & ND & ND \\
\hline Zirconium- 95 & NA & ?9/NA & 11,000 & NA & ND & ND \\
\hline Niobium-95 & NA & $115 / N A$ & 23,000 & NA & ND & ND \\
\hline \multicolumn{4}{|c|}{1976 to 1988 , During reactor operation ${ }^{c}$} & \multicolumn{3}{|c|}{$10 / 89$ to $03 / 90$, During cold standby } \\
\hline Molybdenum- 99 & NA & 73/NA & 400,000 & NA & ND & ND \\
\hline Ruthenium-103 & NA & 100/NA & 39,000 & NA & ND & ND \\
\hline Ant imony-124 & NA & $4 / N A$ & 1,600 & NA & ND & ND \\
\hline Ant imony- 125 & NA & $8 / \mathrm{NA}$ & 5,000 & NA & ND & ND \\
\hline Barium- 140 & NA & 99/NA & 48,000 & NA & ND & ND \\
\hline Cerium- 141 & NA & $72 / N A$ & 15,000 & NA & ND & ND \\
\hline
\end{tabular}




\begin{tabular}{|c|c|c|c|c|c|c|}
\hline $\begin{array}{c}\text { Key } \\
\text { constituents }\end{array}$ & Detection limit $^{a}$ & $\begin{array}{l}\text { Detection/ } \\
\text { analyses }\end{array}$ & $\begin{array}{c}\text { Sample } \\
\text { concentration } \\
(90 \times \mathrm{CI})\end{array}$ & Detection limit $^{a}$ & $\begin{array}{l}\text { Detection/ } \\
\text { analyses }\end{array}$ & $\begin{array}{c}\text { Sample } \\
\text { concentration } \\
(90 x \mathrm{Cl})\end{array}$ \\
\hline Cerium- 144 & NA & 106/NA & 39,000 & MA & ND & ND \\
\hline Plutonium-238 & NA & $201 / \mathrm{NA}$ & 64 & NA & $3 / 3$ & 11 \\
\hline Lead-210 & NA & ND & ND & NA & $1 / 3$ & 3 \\
\hline
\end{tabular}

뭄

Units: chemical $=$ ppb

radionucl ides $=p C i / L$

bConcentrations below Group A study guidel ines; values given for purposes of comparison.

$C_{D}$ isposal of effluent to the $1325-\mathrm{N}$ Crib began in 1983; thus, this data set includes some samples taken before 1983.

CI = confidence interval.

ND = not detected.

ND $=$ not detected. 
Table 13. Initial Analytical Solution Results

for the 1325-N LWDF (WHC 1990a).

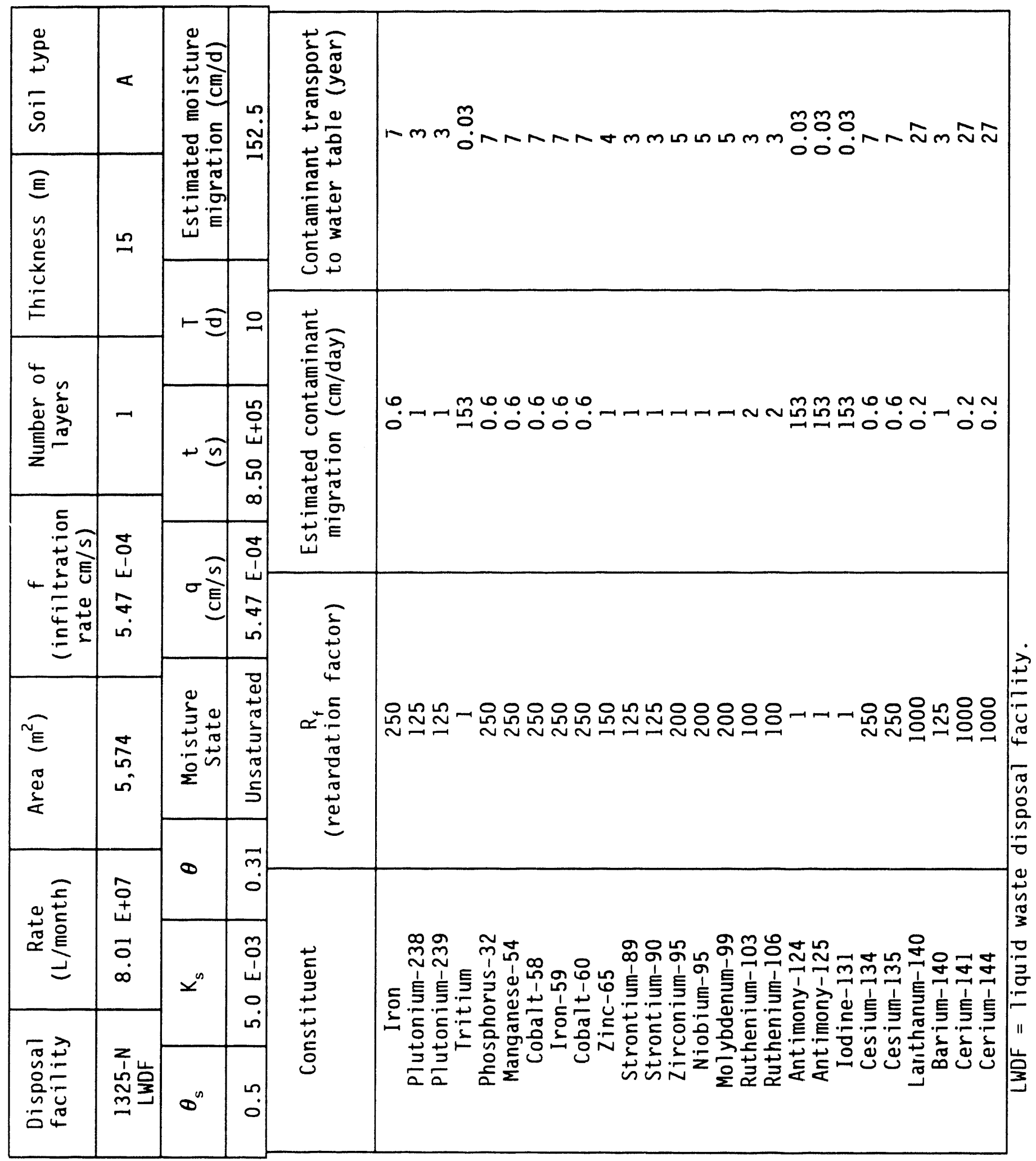


Assuming equilibrium conditions and that laboratory sorption or $K_{d}$ data are representative of soil column conditions, pore fluid strontium-90 concentration $(\mathrm{pC} / \mathrm{mL})$ in the wetted portion of the soil column containing the strontium-90 inventory can be estimated be rearranging equation 4 as follows:

$$
C_{s}, p C i / m L=\frac{C_{w}, p C i / g}{K_{d}}
$$

where:

$C_{s}=$ the adsorbed strontium-90 inventory retained on the sediments in the vadose zone beneath the crib

$C_{w}=$ the pore fluid concentration of strontium-90 in equilibrium with the adsorbed strontium-90 on the sediments.

Ames and Serne (1991) indicate a conservative estimate of 25 for a strontium-90 $K_{d}$ in Hanford Site soils (effluent with low salt content, slightly basic, no complexants, no organics). This is the same value used in Table 13 to estimate the $R_{f}$. Next, an estimate of the strontium-90 concentration in sediments beneath the crib is needed to solve equation 5 for pore fluid concentration. To make this estimate, the following assumptions are used:

- Strontium-90 inventory is uniformly distributed within a volume of sediment defined by the area of the crib

- Depth to the original water table was $15 \mathrm{~m}$ (50 ft)

- Porosity of 0.3 and a sediment density of $2 \mathrm{~g} / \mathrm{mL}$

- Crib contained a total inventory of $60 \mathrm{Ci}$.

This implies that all of the strontium-90 added to the crib had been retained and that it was just at the point of entering the water table when discharges were curtailed. Combining these terms the estimated soil (adsorbed)

strontium-90 concentration is:

$$
C_{s}, p C i / g=\frac{60 \mathrm{Ci} \times 10^{12} \mathrm{pCi} / \mathrm{Ci}}{0.7 \times 15 \mathrm{~m} \times 5574 \mathrm{~m}^{2} \times 1000 \mathrm{~L} / \mathrm{m}^{3} \times 2 \mathrm{~g} / \mathrm{mL} \times 1000 \mathrm{~mL} / \mathrm{L}}=512 \mathrm{Ci} / \mathrm{g}
$$

A factor of 0.7 in the above calculation is used to account for the fact that the volume of solids in a unit volume of soil is $70 \%$ total or bulk volume.

of:

Substituting in equation 5 yields a pore fluid strontium-90 concentration

$$
C_{w}, \mathrm{pCi} / \mathrm{mL}=\frac{512 \mathrm{pCi} / \mathrm{g}}{25}=20 \mathrm{pCi} / \mathrm{mL} \text { or } 20,000 \mathrm{pCi} / \mathrm{L}
$$


Assuming that a slug release of volume (V) of $327,059 \mathrm{~L}(86,400 \mathrm{gal})$ displaces an equal volume of residual fluid from the vadose zone beneath the crib, the $\mathrm{Ci}$ quantity of strontium-90 added to the aquifer from this single event is:

Quantity $=V \times C_{w}=(327,059 \mathrm{~L} \times 20,000 \mathrm{pCi} / \mathrm{L}) /\left(1 \times 10^{12} \mathrm{pCi} / \mathrm{Ci}\right)=0.0065 \mathrm{Ci}$

This estimate suggests that on a relative curie quantity basis (i.e., $0.01 \%$ of the inventory and less than $1 \%$ of the annual strontium-90 previously entering the river), the potential input of additional strontium-90 to the aquifer is not very significant. However, concentrations in groundwater in the vicinity of the crib, even after significant dilution, would be well in excess of the WWQS for this constituent $(8 \mathrm{pCi} / L)$. B! comparison, the highest existing groundwater concentration adjacent to the crib today is $343 \mathrm{pCi} / \mathrm{L}$ in wel1 $\mathrm{N}-29$. Thus, while residual strontium-90 concentrations in groundwater near the crib al ready exceed the WWQS because of past-practice disposal operations, the incremental addition caused by a hypothetical slug release of noncontaminated water in the future could result in much higher concentrations but in a much smaller area than occurred during operations (see Figure 37 , Section 4.3).

5.2.3.2 Infiltration Because of Precipitation. It is also instructive to consider the potential effect of net drainage from precipitation. Assuming a net infiltration of $5 \mathrm{~cm} / \mathrm{yr}$ ( $2 \mathrm{in.} / \mathrm{yr}$ ) distributed over an area the size of the crib, the corresponding volume is:

$$
\text { Volume }=0.05 \mathrm{~m} \times 5570 \mathrm{~m}^{2} \times 1000 \mathrm{~L} / \mathrm{m}^{3}=278,500 \mathrm{~L}(73,572 \mathrm{gal}) .
$$

This is nearly equivalent to the volume resulting from a single slug release as calculated above. The actual volume of "natural" drainage passing through the contaminated sediments is difficilt to determine because the covered area would act as a shield. Drainage from the perimeter of the crib (area from which vegetation is removed) would intersect an unknown portion of the contaminated sediments. Also, the course sands and gravels characteristic of the backfill area around the crib may actually result in infiltration rates approaching the average precipitation rate (about $16 \mathrm{~cm} / \mathrm{yr}[6 \mathrm{in./yr}]$ ).

Regardless of the uncertainties as noted above, natural infiltration of moisture through some fraction of contaminated sediments beneath the crib probably occurs. This represents a continuing source of groundwater contamination that on an annual basis may exceed the amount resulting from a random discharge of spent emergency water.

\subsubsection{Mitigating Factors and Alternative Assumptions}

One mitigating factor for the impact of emergency water disposal, as previously discussed, is that some restoration of water retention capacity of the soil column has probably occurred due to evaporation because intensive use of the crib ceased 2 to 3 years ago. Thus the driving force for the slug release scenario may be less than that assumed for the calculation. 
In addition to the above, a less conservative or more realistic $K_{d}$ value would lower the estimated pore fluid concentration. For example, laboratory sorption studies using sediments from an upgradient location showed that the strontium-90 desorption $\mathrm{K}_{d}$ is a function of the $\mathrm{Ca}^{2+}$ and $\mathrm{Mg}^{2+}$ concentration (moles/L) described by the following regression equation (see Appendix A):

$$
\log K_{d}=-0.89 \log [\mathrm{Ca}+\mathrm{Mg}]-1.06
$$

Assuming the hypothetical slug release of emergency water has a chemical composition similar to river water $(\mathrm{Mg}=6 \mathrm{ppm}$ and $\mathrm{Ca}=23 \mathrm{ppm})$, the $\mathrm{K}_{\mathrm{d}}$ for strontium-90 in 100-N Area sediments would be:

$$
\begin{gathered}
\log K_{d}=-0.89 \log \left[(0.25+0.6) * 10^{-3}\right]-1.06 \\
K_{d}=190
\end{gathered}
$$

Pore fluid strontium-90 concentrations using the higher or less conservative $K_{d}$ from equation 6 in equation 5 would yield an equilibrium concentration of:

$$
(512 \mathrm{pCi} / \mathrm{g}) / 190 \times 1,000 \mathrm{~mL} / \mathrm{L}=2,700 \mathrm{pCi} / \mathrm{L}
$$

Thus, depending on the assumptions used and the release scenario and variables as discussed in previous sections, the pore fluid concentrations could range from about 2,000 to $20,000 \mathrm{pCi} / \mathrm{L}$. Even at the lower end of this range, the concentrations would be significantly greater that the WWQS of $8 \mathrm{pCi} \backslash L$.

In view of the potential magnitude of the increase in local groundwater strontium-90 concentrations from a slug release, the decision to discharge any additional water to this crib should be carefully considered. In addition, some interim action may be appropriate to minimize natural recharge around the cribs. For example, interim restoration of the natural vegetation (Routson and Johnson 1990) to enhance evapotranspiration, may help to reduce the potential for continuing drainage of strontium-90 into the aquifer from this crib.

\subsection{EVALUATION OF MONITORING NETWORK ADEQUACY}

Three RCRA facilities are located in the 100-N Area: the 1301-N LWDF, 1325-N LWDF, and the 1324-N/NA Facilities (see Figure 24). Interim-status groundwater monitoring began at all three facilities in December 1987 (EPA 1989). The facilities are located close together and have interrelated effects on the groundwater hydrology and chemistry of the 100-N Area (DOE-RL 1992b).

The 1301-N LWDF and 1324-N/NA Facilities were monitored under a groundwater quality assessment program during 1991. The 1325-N LWDF was in a detection program in 1991. The 1301-N and 1324-N/NA Facilities went into assessment in the spring of 1989 , because of elevated specific conductance in 
some downgradient wells. The groundwater quality assessment program yielded no evidence that 1301-N or 1324-N/NA have contributed hazardous constituents to the groundwater (Hartman 1990). A new groundwater monitoring plan for the three 100-N Area RCRA sites was issued in 1991 (Hartman 1991). No data were available from the 1991 monitoring when the annual report was written (DOE-RL 1992b).

\subsubsection{Groundwater Monitoring Well Placement}

During 1992, the groundwater in the 100-N Area was monitored quarterly under the RCRA and CERCLA programs. The 1301-N and 1324-N/NA Facilities were monitored under an assessment program and the 1325-N Facility remained under a detection program. Some new wells were added to the monitoring network to replace ones that had gone dry because of the continued drop in water table in the 100-N Area. Tables 14, 15, and 16 list the monitoring wells used for the RCRA and CERCLA programs for the 100-N Area facilities. The tables give information on the following items:

- Age of the well

- Where it is screened

- Its position with the network (e.g., upgradient)

- Sampling frequency

- If water level measurements are also taken

- What standards the wells are constructed to

- If the wells are used by programs other than RCRA (e.g., CERCLA operable unit numbers).

The groundwater monitoring well network for the entire 100-N Area and each of its component RCRA facilities (1301-N and 1325-N LWDFs, 1324-N/NA Facilities) is adequate.

\subsubsection{Reporting of Monitoring Data}

All hydrochemical monitoring data are reported in the HEIS database, which is publicly accessible. Monitoring results for the wells in the 100-N Area, for the period January 1990 through August 1993, were summarized and used to evaluate the groundwater quality and chemistry in Section 4.3 in the previous section. 
Table 14. Wells Used to Monitor Groundwater Chemistry and Water Levels for the 1301-N Liquid Waste Disposal Facility (DOE-RL 1993).

\begin{tabular}{|c|c|c|c|c|c|}
\hline Well & Aquifer & $\begin{array}{l}\text { Sampling } \\
\text { frequency }\end{array}$ & $\begin{array}{l}\text { Water } \\
\text { lev?ls }\end{array}$ & $\begin{array}{c}\text { Well } \\
\text { standards }\end{array}$ & Other networks \\
\hline $199-N-2^{64}$ & $\begin{array}{c}\text { Top of } \\
\text { unconfined }\end{array}$ & $Q$ & $\bar{Y}$ & PRE & -- \\
\hline $199-N-3^{64}$ & $\begin{array}{c}\text { Top of } \\
\text { unconfined }\end{array}$ & $Q$ & $Y$ & PRE & $100-N R-2$ \\
\hline $199-N-14^{69}$ & $\begin{array}{c}\text { Top of } \\
\text { unconfined }\end{array}$ & $Q$ & $\bar{Y}$ & PRE & - \\
\hline $199-\mathrm{N}-17^{81}$ & $\begin{array}{c}\text { Top of } \\
\text { unconfined }\end{array}$ & $Q$ & $\bar{Y}$ & PRE & $\begin{array}{c}1324-N / N A \text { ASMT } \\
10 U-N R-2\end{array}$ \\
\hline $199-N-21^{81}$ & $\begin{array}{c}\text { Top of } \\
\text { unconfined }\end{array}$ & $Q$ & $\bar{Y}$ & PRE & $\begin{array}{c}1324-N / N A \text { ASMT; } \\
100-N R-2\end{array}$ \\
\hline $199-N-47^{84}$ & $\begin{array}{c}\text { Top of } \\
\text { unconfined }\end{array}$ & $Q$ & $\overline{---}$ & PRE & $1324-N / N A$ ASMT \\
\hline $199-N-54^{87}$ & $\begin{array}{c}\text { Top of } \\
\text { unconfined }\end{array}$ & $Q$ & $Y$ & RCRA & $\begin{array}{c}\text { 1324-N/NA ASMT; } \\
100-N R-2\end{array}$ \\
\hline $199-N-55^{87}$ & $\begin{array}{c}\text { Top of } \\
\text { unconfined }\end{array}$ & $Q$ & $Y$ & RCRA & $1324-\mathrm{N} / \mathrm{NA}$ ASMT \\
\hline $199-N-56^{87}$ & $\begin{array}{c}\text { Top of } \\
\text { unconfined }\end{array}$ & $Q$ & $\bar{Y}$ & RCRA & 1324-N/NA ASMT \\
\hline $199-N-57^{87}$ & $\begin{array}{c}\text { Top of } \\
\text { unconfined }\end{array}$ & $\bar{Q}$ & $\bar{Y}$ & RCRA & 1324-N/NA ASMT \\
\hline $\begin{array}{c}199-N-66^{87} \\
U\end{array}$ & $\begin{array}{c}\text { Top of } \\
\text { unconfined }\end{array}$ & $Q$ & $Y$ & RCRA & $100-N R-2$ \\
\hline $199-N-67^{88}$ & $\begin{array}{c}\text { Top of } \\
\text { unconfined }\end{array}$ & $Q$ & $\bar{Y}$ & RCRA & $100-N R-2$ \\
\hline $199-N-69^{88}$ & $\begin{array}{c}\text { Bottom } \\
\text { unconfined }\end{array}$ & $Q$ & $\bar{Y}$ & RCRA & -- \\
\hline $199-\mathrm{N}-75^{92}$ & $\begin{array}{c}\text { Top of } \\
\text { unconfined }\end{array}$ & $Q^{a}$ & $Y(93)$ & RCRA & $100-N R-2$ \\
\hline $199-N-76^{92}$ & $\begin{array}{c}\text { Top of } \\
\text { unconfined }\end{array}$ & $Q^{a}$ & $Y(93)$ & RCRA & $100-N R-2$ \\
\hline
\end{tabular}

Quarterly sampling began the last quarter of 1992.

Note: Superscript following well number denotes the year of installation.

$Y=$ used to monitor water levels (year in parentheses means monitored beginning in that year).

PRE = well was not constructed to RCRA standards.

$Q=$ frequency on a quarterly basis.

RCRA = well is in compl iance with Resource Conservation and Recovery Act of 1976 (RCRA standards).

$U=$ upgradient well in sampl ing network.

ASMT $=$ assessment. 


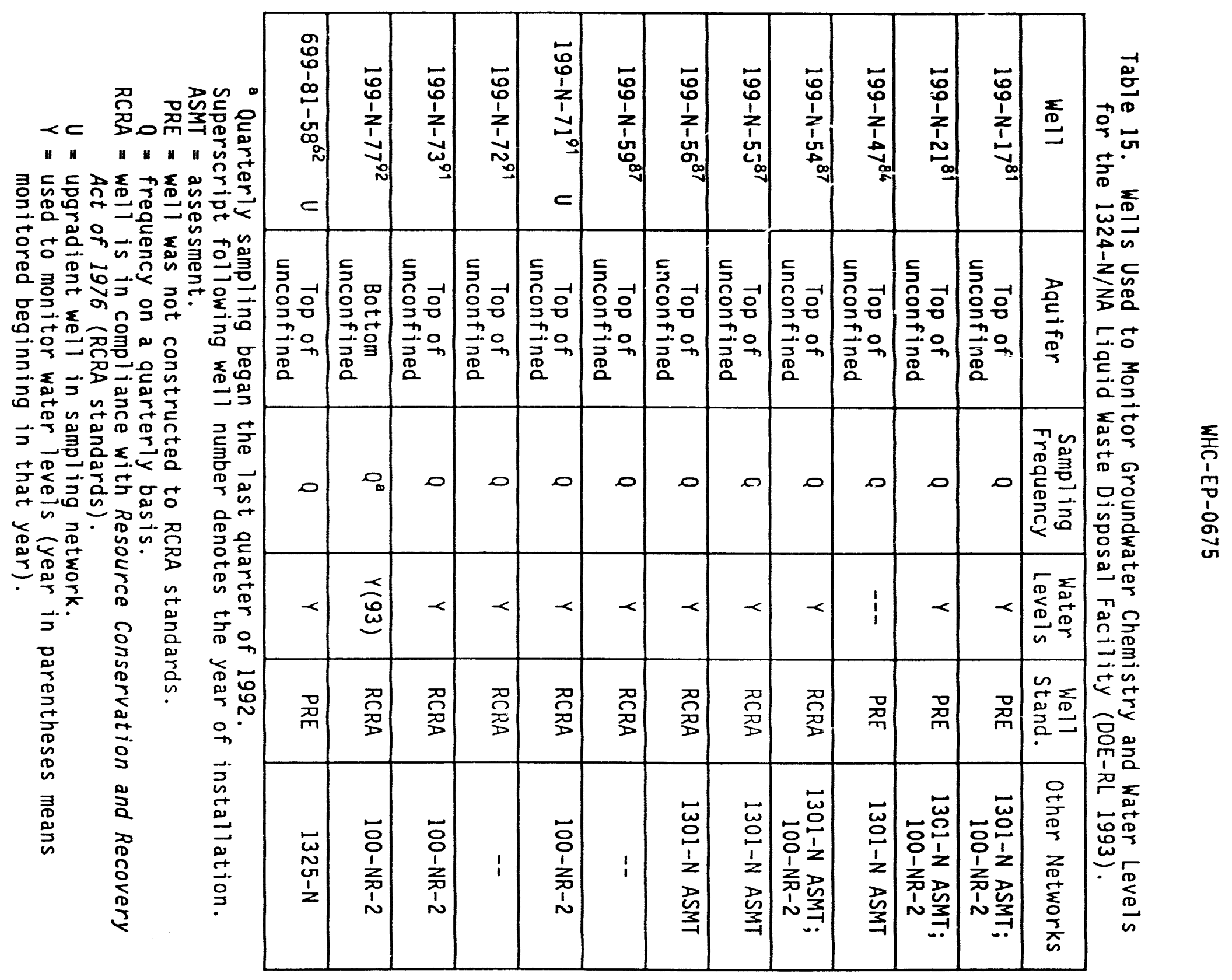


Table 16. Wells Used to Monitor Groundwater Chemistry and Water Levels for the 1325-N Liquid Waste Disposal Facility (DOE-RL 1993).

\begin{tabular}{|c|c|c|c|c|c|}
\hline Well & Aquifer & $\begin{array}{l}\text { Sampling } \\
\text { Frequency }\end{array}$ & $\begin{array}{l}\text { Water } \\
\text { Levels }\end{array}$ & $\begin{array}{l}\text { We11 } \\
\text { Stand. }\end{array}$ & $\begin{array}{l}\text { Other } \\
\text { Networks }\end{array}$ \\
\hline $199-N-27^{839}$ & $\begin{array}{c}\text { Top of } \\
\text { unconfined }\end{array}$ & $S A$ & $\bar{Y}$ & PRE & -- \\
\hline $199-N-29^{83}$ & $\begin{array}{c}\text { Top of } \\
\text { unconfined }\end{array}$ & $S A$ & $Y$ & PRE & -- \\
\hline $199-N-31^{83}$ & $\begin{array}{c}\text { Top of } \\
\text { unconfined }\end{array}$ & $\overline{S A}$ & $\bar{Y}$ & PRE & -- \\
\hline $199-N-32^{83}$ & $\begin{array}{c}\text { Top of } \\
\text { unconfined }\end{array}$ & $\overline{S A}$ & $\bar{Y}$ & PRE & $100-N R-2$ \\
\hline $199-N-33^{83}$ & $\begin{array}{c}\text { Top of } \\
\text { unconfined }\end{array}$ & $\overline{S A}$ & $\bar{Y}$ & $\overline{\text { PRE }}$ & - \\
\hline $199-N-41^{84}$ & $\begin{array}{c}\text { Top of } \\
\text { unconfined }\end{array}$ & $\overline{S A}$ & $\bar{Y}$ & PRE & -- \\
\hline $199-N-70^{88}$ & $\begin{array}{c}\text { Bottom } \\
\text { unconfined }\end{array}$ & $\bar{Q}$ & $\bar{Y}$ & RCRA & $100-N R-2$ \\
\hline $199-N-74^{91} U$ & $\begin{array}{c}\text { Top of } \\
\text { unconf ined }\end{array}$ & $Q$ & $Y$ & RCRA & $100-N R-2$ \\
\hline $699-81-58^{62} \quad U$ & $\begin{array}{c}\text { Top of } \\
\text { unconfined }\end{array}$ & $\bar{Q}$ & $\bar{Y}$ & PRE & $\begin{array}{c}1324-N / N A \\
\text { ASMT }\end{array}$ \\
\hline
\end{tabular}

${ }^{\circ} \mathrm{A}$ though wells $\mathrm{N}-27$ and $\mathrm{N}-29$ are currently downgradient of the 1325-LWDF, they were downgradient when the facility was active. The groundwater chemistry at these wells is still affected by the facility, so they are monitored as downgradient wells.

Note: Quarterly sampling began the last quarter of 1992.

Superscript following well number denotes the year of installation.

ASMT $=$ assessment.

PRE = well was not constructed to RCRA standards.

$Q=$ frequency on a quarterly basis.

$S A=$ frequency on a semi-annual basis.

RCRA $=$ well is in compliance with Resource Conservation and Recovery Act of 1976 (RCRA) standards.

$U=$ upgradient well in sampling network.

$Y=$ used to monitor water levels (year in parentheses means monitored beginning in that year). 


\subsection{SUMMARY AND CONCLUSIONS}

One-dimensional or unit gradient transport and flow calculations suggest that strontium-90 should have reached the water table during the operational period of use for the 1325-N Crib. The occurrence of strontium-90 in groundwater in the immediate vicinity of the crib is consistent with the predicted breakthrough, supporting the assumptions and methods used for estimating contaminant migration rates through the soil column.

The continuing migration of strontium-90 into the aquifer may be occurring caused by natural recharge. The estimated magnitude of additional strontium-90 input to the aquifer because of single hypothetical slug releases of spent emergency water appears to be about the same order of magnitude as the annual input caused by natural recharge. The localized concentrations because of both types of input exceed the WWQS of $8 \mathrm{pCi} / \mathrm{L}$ for strontium-90 and mitigating measures for controlling the natural infiltration around the crib (e.g., restoration of natural vegetation around the crib or installation of an interim infiltration barrier) shnuld be investigated as part of ongoing remediation efforts. Likewise, emergency water disposal should not be discharged to the crib.

Other groundwater constituents with elevated concentrations in the 100-N Area are nitrate, tritium, sulfate, sodium, and chloride. These parameters are being investigated by the RCRA Monitoring Program as part of ongoing investigations within the 100-N Area. Tritium contamination is also being addressed as part of a 100-N Area Expedited Response Action. The groundwater monitoring well network for this site is adequate. 
WHC-EP-0675

This page intentionally left blank. 


\subsection{REFERENCES}

Ames, L. L., and R. J. Serne, 1991, Compilation of Data to Estimate Groundwater Migration Potential for Constituents in Active Liquid Discharges at the Hanford Site, PNL-7660, Pacific Northwest Laboratory, Richland, Washington.

Baker, V. R., B. N. Bjornstad, A. J. Busacca, K. R. Fecht, E. P. Kiver, U. L. Moody, J. G. Rigby, D. F. Stradling, and A. M. Tallman, 1989, "Quaternary Geology of the Columbia Plateau," in Quaternary Nonglacial Geology; Conterminous United States, R. B. Morrison (editor), Geological Society of America, The Geology of North America, v. K-2, p. 215-250, Boulder, Colorado.

Bjornstad, B. N., 1984, Suprabasalt Stratigraphy Within and Adjacent to the Reference Repository Location, SD-BWI-DP-039, Rockwell Hanford Operations, Richland, Washingicon.

Black, R. F., 1979, Clastic Dikes of the Pasco Basin, Southeastern Washington, RHO-BWI-C-64, Rockwell Hanford Operations, Richland, Washington.

Campbe11, N. P., 1989, Structural and Stratigraphic Interpretation of Rocks Under the Yakima Fold Belt, Columbia Basin, Based on Recent Surface Mapping and Well Data, in Volcanism and Tectonism in the Columbia FloodBasalt Province, Special Paper 239, edited by S. P. Reidel and P. R. Hooper, Geological Society of America, Boulder, Colorado, p. 209-222.

Cantre11, K. J., and R. J. Serne, 1993, DRAFT (March 1993) - Adsorption and Desorption of Sr-90 on Hanford Sediment - Status Report, Letter Report for Westinghouse Hanford Company from Pacific Northwest Laboratory, Richland, Washington.

Comprehensive Environmental Response, Compensation, and Liability Act of 1980, 42 USC 9601 , et seq.

Cushing, C. E. (ed.), 1989, Hanford Site National Environmental Policy Act (NEPA) Characterization, PNL-6415, prepared by Pacific Northwest Laboratory for the U.S. Department of Energy, Richland, Washington.

Delaney, C. D., K. A. Lindsey, and S. P. Reidel, 1991, Geology and Hydrology of the Hanford Site: A Standardized Text for Use in Westinghouse Hanford Company Documents and Reports, WHC-SD-ER-TI-003, Rev. 0, Westinghouse Hanford Company, Richland, Washington.

Diediker, L. A., and J. A. Hal1, 1987, Closure/Post-Closure Plan for the 1301-N and 1325-N Liquid Waste Disposal Facilities, UNI-3533, UNC Nuclear Industries, Inc., Richland, Washington.

DOE, 1987, Final Environmental Impact Statement--Disposal of Hanford Defense High-Level, Transuranic and Tank Wastes, Vols. 1 to 5, DOE/EIS-0113, U.S. Department of Energy, Washington, D.C. 
DOE, 1988, Site Characterization Plan, Reference Repository Location, Hanford Site, Washington, Consultation Draft, DOE/RW-0164, U.S. Department of Energy, Washington, D.C.

DOE-RL, 1990, Remedial Investigation/Feasibility Study Work Plan for the 300-FF-5 Operable Unit, Hanford Site, Richland, Washington, DOE/RL 89-14, U.S. Department of Energy, Richland Operations Office, Richland, Washington.

DOE-RL, 1991a, RC.RA Facility Investigation/Corrective Measures Study Work Plan for the 100-NR-1 Operable Unit, Hanford Site, Richland, Washington, DOE/RL 91-46, U.S. Department of Energy, Richland Operations Office, Richland, Washington.

DOE-RL, 1991b, RCRA Facility Investigation/Corrective Measures Study Work Plan for the 100-NR-2 Operable Unit, Hanford Site, Richland, Washington, DOE/RL 90-22, U.S. Department of Energy, Richland Operations Office, Richland, Washington.

DOE-RL, 1992c, Sampling and Analysis of 100 Areas Springs, DOE/RL 92-12, Rev. 1, U.S. Department of Energy, Richland Operations Office, Richland, Washington.

DOE-RL, 1992a, Annual Report for RCRA Groundwater Monitoring Projects at Hanford site Facilities for 1991, DOE/RL-92-03, Rev. 0, U.S. Department of Energy, Richland Operations Office, Richland, Washington.

DOE-RL, 1992b, Hanford Site Groundwater Background, DOE/RL-92-23, U.S. Department of Energy, Rich ${ }^{7}$ and Field Office, Richland, Washington.

DOF:-RL, 1993, Annual Report for RCRA Groundwater Monitoring Projects at Hanford Site Facilities for 1992, DOE/RL-93-09, Rev. 0, U.S. Department of Energy, Richland Operations Office, Richland, Washington.

Ecology, EPA, DOE-RL, 1991, Hanford Federal Facility Agreement and Consent Order, Second amendment. Two volumes, 89-10 Revision 2, Washington Department of Ecology, 0lympia, Washington, U.S. Environmental Protection Agency, Region X, Seattle, Washington, and U.S. Department of Energy, Richland Operations office, Richland, Washington.

Energy Research and Development Administration (ERDA), 1975, Final Environmental Impact Statement on Waste Management Operations, Hanford Reservation, ERDA-1538, 2 volumes, Washington, D.C.

EPA, 1989, "Interim Status Standards for Owners and Operators of Hazardous Waste Treatment, Storage, and Disposal Facilities," Title 40, Code of Federal Regulations, Part 265, as amended, U.S. Environmental Protection Agency, Washington, D.C.

Fecht, K. R., S. P. Reidel, and A. M. Tallman, 1987, Paleodrainage of the Columbia River System on the Columbia Plateau of Washington State -A Summary, in Selected Papers on the Geology of Washington, Division of Geology and Earth Resources, Bulletin 77, p. 219-248, edited by J. E. Schuster. 
Gee, G. W., 1987, Recharge of the Hanford Site: Status Report, PNL-6403, Pacific Northwest Laboratory, Richland, Washington.

Gephart, R. E., R. C. Arnett, R. G. Baca, L. S. Leonhard, and F. A. Spane, Jr., 1979, Hydrologic Studies within the Columbia Plateau, Washington: An Integration of Current Knowledge, RHO-BWI-ST-5, Rockwell Hanford Operations, Richland, Washington.

Graham, M. J., M. D. Hall, S. R. Strait, and W. R. Brown, 1981, Hydrology of the Separations Area, RHO-ST-42, Rockwell Hanford Operations, Richland, Washington.

Graham, M. J., G. V. Last, and K. R. Fecht, 1984, An Assessment of Aquifer Intercommunication in the $B$ Pond-Gable Mountain Pond Area of the Hanford Site, RHO-RE-ST-12, Rockwell Hanford Operations, Richland, Washington.

Hartman, M. J., 1990, Results of Groundwater Quality Assessment Monitoring at the 1301-N Liquid Waste Disposal Facility and 1324-N/NA Facilities, WHC-SD-EN-EV-003, Westinghouse Hanford Company, Richland, Washington.

Hartman, M. J., 1991, Groundwater Monitoring Plan for the 1301-N, 1324-N/NA, and 1325-N Facilities, WHC-SD-EN-AP-038, Rev. 0, Westinghouse Hanford Company, Richland, Washington.

Hartman, M. J., 1992, Borehole Completion Data Package for Wells 199-N-71, 199-N-72, 199-N-73, and 199-N-74, WHC-SD-EN-DP-040, Rev. 0, Westinghouse Hanford Company, Richland, Washington.

Hartman, M. J., 1993, Groundwater Monitoring Plan for the 1301-N and 1325-N Facilities, WHC-SD-EN-AP-038, Rev. 1, Westinghouse Hanford Company, Richland, Washington.

Hartman, M. J., and R. E. Peterson, 1992, Hydrologic Information Summary for the Northern Hanford Site, Washington, WHC-SD-EN-TI-023, Westinghouse Hanford Company, Richland, Washington.

Johnson, V. G., 1993, Westinghouse Hanford Company Operational Groundwater Status Report, WHC-EP-0595, Westinghouse Hanford Company, Richland, Washington.

Last, G. V., B. N. Bjornstad, M. P. Bergeron, R. W. Wallace, D. R. Newcomer, J. A. Schramke, M. A. Chamness, C. S. Cline, S. P. Airhart, and J. S. Wilbur, 1989 , Hydrogeology of the 200 Areas Low-Level Burial Grounds -- An Interim Report, PNL-6820, Pacific Northwest Laboratory, Richland, Washington.

Liikala, T. L., R. L. Aaberg, N. J. Aimo, D. J. Bates, 1988, Geohydrologic Characterization of the Area Surrounding the 183-H Solar Evaporation Basins, PNL-6728, Pacific Northwest Laboratory, Richland, Washington.

Lindberg, J. W., and F. W. Bond, 1979, Geohydrology and Groundwater Quality Beneath the 300 Area, Hanford Site, Washington, PNL-2949, Pacific Northwest Laboratory, Richland, Washington. 
Lindsey, K. A., 1991a, Revised Stratigraphy for the Ringold Formation, Hanford Site, South-Central Washington, WHC-SD-EN-EE-004, Rev. 0, Westinghouse Hanford Company, Richland, Washington.

Lindsey, K. A., 1991b, Sedimentation and Basin Evolution of the Late Neogene Ringold Formation, Central Columbia Plateau, South-Central Washington, Geological Society of America Abstracts with Programs, v. 23, no. 5, p. A285, Boulder, Colorado.

Lindsey, K. A., M. P. Connelly, and B. N. Bjornstad, 1991, Geologic Setting of the 200 West Area: An Update, WHC-SD-EN-TI-008, Westinghouse Hanford Company, Richland, Washington.

Lindsey, K. A., 1992, Geology of the Northern Part of the Hanford Site: An Outline of Data Sources and the Geologic Setting of the 100 Areas, WHC-SD-EN-TI-011, Westinghouse Hanford Company, Richland, Washington.

Myers, C. W., S. M. Price, J. A. Caggiano, M. P. Cochran, W. J. Czimer, N. J. Davidson, R. C. Edwards, K. R. Fecht, G. E. Holmes, M. G. Jones, J. R. Kunk, R. D. Landon, R. K. Ledgerwood, J. T. Lillie, P. E. Long, T. H. Mitchell, E. H. Price, S. P. Reidel, and A. M. Tallman, 1979, Geologic Studies of the Columbia Plateau: A Status Report, RHO-BWI-ST-4, Rockwell Hanford Operations, Richland, Washington.

Newcomb, R. C., and S. G. Brown, 1961, Evaluation of Bank Storage Along the Columbia River Between Richland and China Bar, Washington, Water-Supply Paper 1539-I, U.S. Geological Survey, Washington, D.C.

Peterson, R. E., and V. G. Johnson, 1992, Riverbank Seepage of Groundwater Along the 100 Areas Shoreline, Hanford Site, WHC-EP-0609, Westinghouse Hanford Company, Richland, Washington.

PSPL, 1982, Skagit/Hanford Nuclear Project, Preliminary Safety Analysis Report, Vol. 4, App. 20, Amendment 23, Puget Sound Power and Light Company, Bellevue, Washington.

Reidel, S. P., 1984, "The Saddle Mountains: The Evolution of an Anticline in the Yakima Belt," American Journal of Science, v. 284, p. 942-978.

Reidel, S. P., and K. R. Fecht, 1981, Wanapum and Saddle Mountains Basalt in the Cold Creek Syncline Area, in Subsurface Geology of the Cold Creek Syncline, RHO-BWI-ST-14, Rockwell Hanford Operations, Richland, Washington.

Reidel, S. P., and P. R. Hooper, 1989, editors, "Volcanism and Tectonism in the Columbia River Flood Basalt Province," Special Paper 239, Geological Society of America, Boulder, Colorado, p. 386.

Reidel, S. P., K. R. Fecht, M. C. Hagood, and T. L. Tolan, 1989, "The Geologic Evolution of the Central Columbia Plateau," in Volcanism and Tectonism in the Columbia River Flood-Basalt Province, Special Paper 239, edited by S. P. Reidel and P. R. Hooper, Geological Society of America, Boulder, Colorado, p. 247-264. 
Reide1, S. P., K. A. Lindsey, and K. R. Fecht, 1992, Field Trip Guide to the Hanford Site, WHC-MR-0391, Westinghouse Hanford Company, Richland, Washington.

Resource Conservation and Recovery Act of 1976, 42 USC 6901, et seq.

Rockhold, M. L., M. J. Fayer, G. W. Gee, and M. J. Kanyid, 1990, Natural Groundwater Recharge and Water Balance at the Hanford Site, PNL-7215, Pacific Northwest Laboratory, Richland, Washington.

Routson, R. C., and V. G. Johnson, 1990, "Recharge Estimates for the Hanford Site 200 Areas Plateau," Northwest Science, v. 64, no. 3.

Serkowski, J. A., and W. A. Jordan, 1989, Operational Groundwater Monitoring at the Hanford Site--1988, WHC-EP-0260, Westinghouse Hanford Company, Richland, Washington.

Smith, G. A., 1988, Neogene Synvolcanic and Syntectonic Sedimentation in Central Washington, v. 100, p. 1479-1492, Geological Society of America Bulletin, Boulder, Colorado.

Smith, G. A., B. N. Bjornstad, and K. R. Fecht, 1989, "Neogene Terrestrial Sedimentation on and Adjacent to the Columbia Plateau; Washington, Oregon, and Idaho," in Volcanism and Tectonism in the Columbia River Flood-Basalt Province, Special Paper 239, edited by S. P. Reidel and P. R. Hooper, Geological Society of America, Boulder, Colorado, p. 187-198.

Stordeur, R. T., and D. L. Flyckt, 1988, Annual Status Report of the Plan and Schedule to Discontinue Disposal of Contaminated Liquids into the Soil Column at the Hanford Site, WHC-EP-0196-1, Westinghouse Hanford Company, Richland, Washington.

Tallman, A. M., K. R. Fecht, M. C. Marratt, and G. V. Last, 1979, Geology of the Separations Areas, Hanford Site, South-Central Washington, RHO-ST-23, Rockwell Hanford Operations, Richland, Washington.

Tallman, A. M., J. T. Lillie, and K. R. Fecht, 1981, Suprabasalt Sediments of the Cold Creek Syncline Area, in Subsurface Geology of the Cold Creek Syncline, RHO-BWI-ST-14, C. W. Myers, and S. M. Price, Rockwell Hanford Operations, Richland, Washington.

Tolan, T. L., and S. P. Reidel, 1989, "Structure Map of a Portion of the Columbia River Flood-Basalt Province," in Volcanism and Tectonism in the Columbia River Flood-Basalt Province, Special Paper 239, edited by S. P. Reidel and P. R. Hooper, Geological Society of America, Boulder, Colorado, plate 1.

Tolan, T. L., S. P. Reidel, M. H. Beeson, J. L. Anderson, K. R. Fecht, and D. A. Swanson, 1989, "Revisions to the Extent and Volume of the Columbia River Basalt Group," in Volcanism and Tectonism in the Columbia River Flood-Basalt Province, Special Paper 239, edited by S. P. Reidel and P. R. Hooper, Geological Society of America, Boulder, Colorado, p. 1-20. 
Tyler, D. K., 1991, A Methodology for Assessing Impacts to Groundwater from Disposal of Liquid Effluent to the Soil at the Hanford Site, WHC-SD-EN-EV-008, Rev. 0, Westinghouse Hanford Company, Richland, Washington.

UNC, 1987, Closure/Post-Closure of the 1324-NA Percolation Pond, UNC Nuclear Industries, Inc., Richland, Washington.

WAC 173-200, 1990, "Water Quality Standards of the State of Washington," Washington Administrative Code, as amended.

WAC 173-303-090, 1990, "Dangerous Waste Regulations," Washington Administrative Code, as amended.

WHC, 1989a, (NUSAR) N-Reactor Updated Safety Analysis Report, WHC-SP-0297, Volume 5, Amendment 21, Westinghouse Hanford Company, Richland, Washington.

WHC, 1989b, Waste Stream Characterization Report, WHC-EP-0287, Vo1. 3, Westinghouse Hanford Company, Richland, Washington.

WHC, 1990a, Liquid Effluent Study Final Project Report, WHC-EP-0367, Westinghouse Hanford Company, Richland, Washington.

WHC, 1990b, Liquid Effluent Study: Ground Water Characterization Data, WHC-EP-0366, Westinghouse Hanford Company, Richland, Washington.

WHC, 1990C, N Reactor Effluent Stream-Specific Report, WHC-EP-0342, Addendum 3, Westinghouse Hanford Company, Richland, Washington.

WHC, 1993, Draft Characterization Report for the Table 4 Miscellaneous Streams in Consent Order No. DE 91NM-177, WHC-SD-EN-EV-020, Draft 6-28-93, Westinghouse Hanford Company, Richland, Washington.

WPPSS, 1974, Preliminary Safety Analysis Report, WPPSS Nuclear Project No. 1, Amendment 5, Section 2.5 and Appendix 2, Washington Public Power Supply System, Richland, Washington. 
WHC-EP-0675

APPENDIX A

A-i 
WHC-EP-0675

Letter Report for Westinghouse Hanford Company

ADSORPTION AND DESORPTION OF ST-9O ON HANFORD SEDIMENT

STATUS REPORT

\section{DRAFT}

K. J. Cantrell

R. J. Seme

March 1993

Prepared for

the U.S. Department of Energy

under Contract DE-AC06-76RLO 1830

Pacific Northwest Laboratory

Richland. Washington $\$ 9352$ 


\title{
SUMMARY
}

\author{
Introduction
}

Despite the fact that the flux of radionuclides and water into the 1301-N and 1325-N disposal trenches has diminished significantly since the shutdown of the $N$ Reactor, the observed concentrations of $90 \mathrm{Sr}$ in the compliance well $\mathrm{N}-8 \mathrm{t}$ have shown a slight increase in $90 \mathrm{Sr}$ concentration from March 1991 to May 1992. One explanation for the observed increase in $90 \mathrm{Sr}$ concentrations is that the chemical composition of water flowing through contaminated sediments thas changed significantly and is now causing previously adsorbed $90 \mathrm{Sr}$ to desorb. $\mathrm{Sr}$ adsorption is known to be quite sensitive to competing cations such as $\mathrm{Ca}^{2+}, \mathrm{Mg}^{2+}, \mathrm{Na}^{+}, \mathrm{K}+$, and $\mathrm{H}+$. This study was initiated to gain a better understanding of the adsorptiondesorption properties of strontium onto/from 100-N Area sediments and how changes in groundwater chemistry can effect these properties.

\section{Available Chemical Data}

The available historical chemical data from the 100-N Area, which are useful from a geochemical perspective, are sparse. The lack of historical major ion data, in particular, has hampered a thorough geochemical analysis of the competitive adsorption/desorption reactions that occur between $90 \mathrm{Sr}$ and major cations. Some interesting results, however, are available for well N-3. For example, in Figure 1,90Sr concentrations in Well $\mathrm{N}-3$ are plotted as a function of time along with $\mathrm{Ca}$ concentrations. The increase in $90 \mathrm{Sr}$ concentration appears to be well correlated with an increase in $\mathrm{Ca}+\mathrm{Mg}$ concentration. These results are consistent with our hypothesis that ion-exchange of $\mathrm{Ca}$ and $\mathrm{Mg}$ for previously adsorbed $\mathrm{Sr}$ is responsible for the increases in $90 \mathrm{Sr}$ observed in well $\mathrm{N}$-8t. Other major ion data from $\mathrm{N}$-Area indicate that high concentrations of ion-exchange regenerant solutions disposed in 1324-N/NA were over 1 Molar in $\mathrm{Na}$ concentration. Disposal of these solutions directly into the vadose zone has resulted in greatly elevated concentrations of sodium in the groundwater in the vicinity of the 1324N/NA disposal site. The elevated sodium concentratioris in the groundwater causes desorption of Ca from exchange sites, resulting in elevated $C_{2}$ ioncentratioris.

\section{Equilibrium Batch Sorption Results}

$K_{d}$ values determined in the batch adsorption and desorption experiments are listed in Table 1. The $K_{d}$ values listed in the $K_{d}(a d s)$ column were determined after three days of adsorption. Values listed under $K_{d}(d e s 1)$ were determined after 16 days of desorption. Both $K_{d}(a d s)$ and $K_{d}($ des 1$)$ values were calculated using a mass balance approach based upon the initial and final concentration values of $85 \mathrm{Sr}$ in solution. $K_{d}$ values under the $K_{\sigma}(d e s 2)$ column were determined directly by measuring the concentrations both in solution and in the sediment after the 16 day equilibration period. The quality of the $K_{d}$ data which were determined directly are clearly much more reproducible. For example, the experiments 13 through 17 all have the same initial calcium and magnesium concentrations and we would therefore expect the $K_{d}$ results to be very similar for all of these experiments. The $K_{d}(d e s 1)$ results for these 


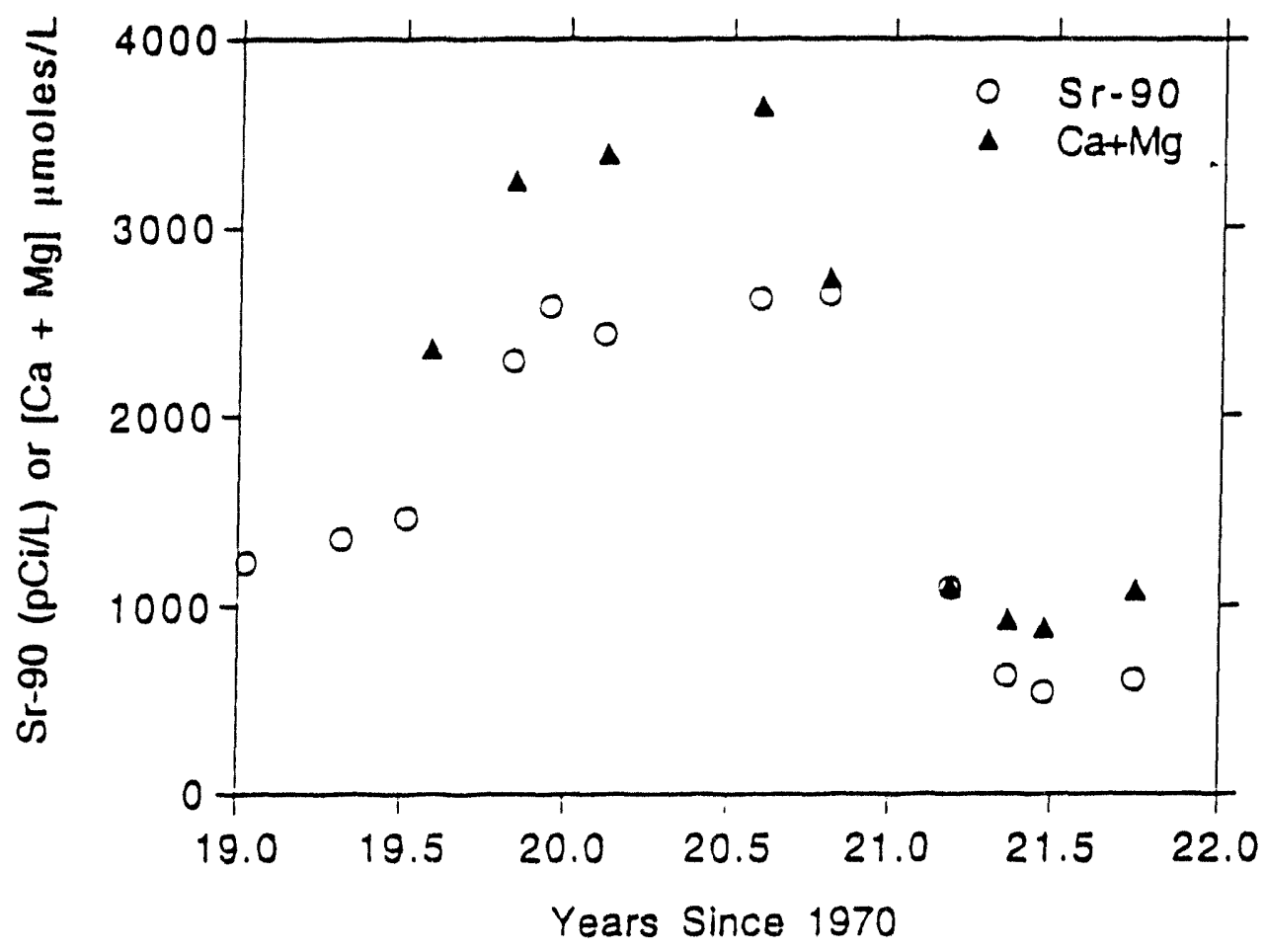

Figure 1. Sr-90 ( $\mathrm{pC} / \mathrm{L}$ ) and the sum of $\mathrm{Ca}$ and $\mathrm{Mg}$ ( $\mu$ moles $/ L$ ) concentrations in well $\mathrm{N}-3$ as function of time.

experiments ranged from -11 to 46 . This is a large difference. The $K_{d}$ (des2) results, however, ranged from 10 to 14. The $K_{d}$ (des2) results are plotted in Figure 3 as a function of the final solution concentration of $\mathrm{Ca}$ plus $\mathrm{Mg}$. We can see that a very good linear correlation exists. These results support our hypothesis that $\mathrm{Sr}$ is adsorbed 10 ion-exchange sites and that $\mathrm{Ca}$ and $\mathrm{Mg}$ are effective competitors for these sites. These results also suggest that, with our geochemical model, we should be able to predict the future concentrations of $90 \mathrm{Sr}$ in groundwater by combining current $90 \mathrm{Sr}$ and major ion data from various $100-\mathrm{N}$ Area wells with modeling results of the future movement of the high salt content plume from the 1324 waste disposal pit. Major ion concentrations and $\mathrm{pH}$ values measured at equilibrium for these experiments are listed in Table 2. 
WHC-EP-0675

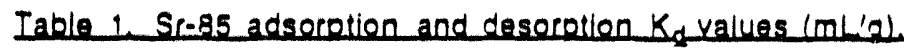

\begin{tabular}{|c|c|c|c|}
\hline Exout & $K_{d}(a d s)$ & $K_{\sigma}(\operatorname{des} 1)$ & $K_{d}(\operatorname{des} 2)$ \\
\hline 1 & 96 & 111 & $\cdot$ \\
\hline 2 & 18 & 25 & 50 \\
\hline 3 & 50 & 85 & 102 \\
\hline 4 & 19 & 40 & 43 \\
\hline 5 & 105 & 145 & 220 \\
\hline 6 & 24 & 45 & 62 \\
\hline 7 & 42 & 82 & 122 \\
\hline 8 & 21 & 42 & 39 \\
\hline 9 & 57 & 114 & 157 \\
\hline 10 & 25 & 50 & 47 \\
\hline 11 & 2,7 & -6.3 & 12 \\
\hline 12 & 2.7 & 1.0 & 12 \\
\hline 13 & 6.8 & 26 & 14 \\
\hline 14 & 1.3 & $\cdot 11$ & 11 \\
\hline 15 & 5.5 & 20 & 11 \\
\hline 16 & 11 & 46 & 13 \\
\hline 17 & 10 & 42 & 10 \\
\hline i8 & 10 & 12 & 20 \\
\hline 19 & 7 & 20 & 17 \\
\hline 20 & 8 & 20 & 13 \\
\hline 21 & 10 & 24 & 15 \\
\hline 22 & 8 & 5 & 24 \\
\hline
\end{tabular}


WHC-EP-0675

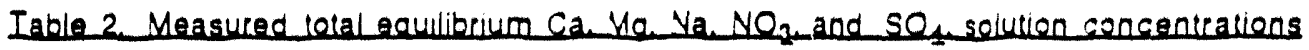
imillimoles/liter and $\mathrm{OH}$ lor and S.-85 adsorotion and desorotion experiments.

\begin{tabular}{|c|c|c|c|c|c|c|}
\hline Exput & ca & $\mathrm{Mo}$ & $\Delta$ & $\Delta 0_{3}$ & $\mathrm{SO}_{1}$ & $\otimes$ \\
\hline 1 & 0.182 & 0.016 & 0.032 & 0.000 & 0.000 & 7.38 \\
\hline 2 & 0.724 & 0.016 & 0.020 & 1.274 & 0.000 & 7.32 \\
\hline 3 & 0.195 & 0.185 & 0.005 & 0.339 & 0.000 & 7.45 \\
\hline 4 & 0.773 & 0.185 & 0.022 & 1.597 & 0.000 & 7.33 \\
\hline 5 & 0.137 & 0.012 & 0.783 & 0.000 & 0.323 & 7.22 \\
\hline 6 & 0.724 & 0.016 & 0.783 & 1.290 & 0.375 & 7.24 \\
\hline 7 & 0.160 & 0.152 & 0.783 & 0.339 & 0.375 & 7.18 \\
\hline 8 & 0.873 & 0.177 & 0.105 & 1.903 & 0.312 & 7.03 \\
\hline 9 & 0.145 & 0.078 & 0.391 & 0.161 & 0.187 & 7.34 \\
\hline 10 & 0.724 & 0.095 & 0.396 & 1.419 & 0.187 & 7.08 \\
\hline 11 & 3.27 & 0.012 & 3.96 & 6.725 & 2.020 & 6.90 \\
\hline 12 & 3.27 & 1.73 & 3.96 & 9.661 & 1.853 & 7.01 \\
\hline 13 & 3.29 & 0.864 & 0.022 & 8.015 & 0.000 & 7.16 \\
\hline 14 & 3.24 & 0.864 & 7.79 & 7.967 & 3.727 & 6.98 \\
\hline 15 & 3.24 & 0.364 & 3.92 & 7.383 & 1.791 & 6.94 \\
\hline 16 & 3.29 & 0.864 & 3.96 & 8.145 & 1.332 & 7.01 \\
\hline 17 & 3.27 & 0.864 & 3.96 & 8.209 & 1.832 & 6.99 \\
\hline 18 & 1.70 & 0.012 & 0.017 & 3.242 & 0.031 & 7.26 \\
\hline 19 & 2.00 & 0.864 & 3.36 & 5.467 & 1.791 & 7.05 \\
\hline 20 & 1.67 & 1.67 & 11.2 & 6.741 & 5.517 & 7.05 \\
\hline 21 & 1.70 & 1.73 & 0.017 & 6.951 & 0.000 & 7.24 \\
\hline 22 & 1.70 & 0.012 & 11.0 & 3.113 & 5.247 & 7.36 \\
\hline
\end{tabular}




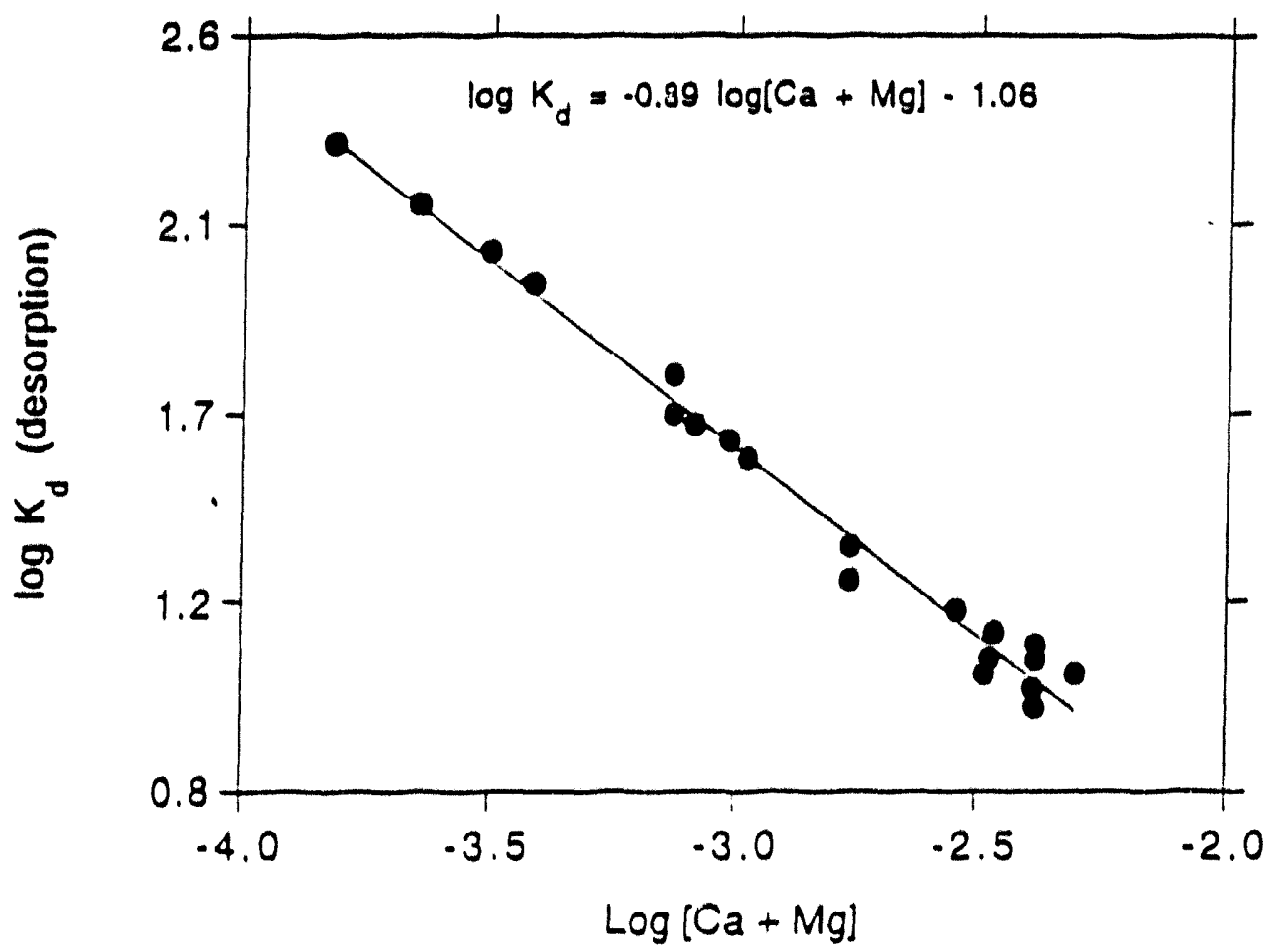

Figure 3. Sr-85 $K_{d}$ values as a function of the sum of the equilibrium calcium and magnesium concentrations in solution for 100-N Area sediment.

\section{Kinetic Batch Somtion Results}

Several attempts have been made to determine reliable adsontion kinetics data which could be used along with the equilibrium $K_{d}$ results as a check on the column adsorptiondesorption modeling results which will be discussed later. In our first attempt to determine the kinetics of strontium adsorption, the adsorption solutions had such a high calcium concentrations that essentially no strontium adsorption occurred. In our second attempt, the initial calcium concentration was very low. However, calcium dissolved from the sediment during the experiment. which caused the equilibrium $K_{d}$ to change during the course of the experiment. As a result the usefuiness of the data was compromised. Results from our last set of kinetics experiments are shown in Figure 2. Although we can see that equilibrium is reached in about two weeks or less, the uncertainty of the data is greater than desired. 


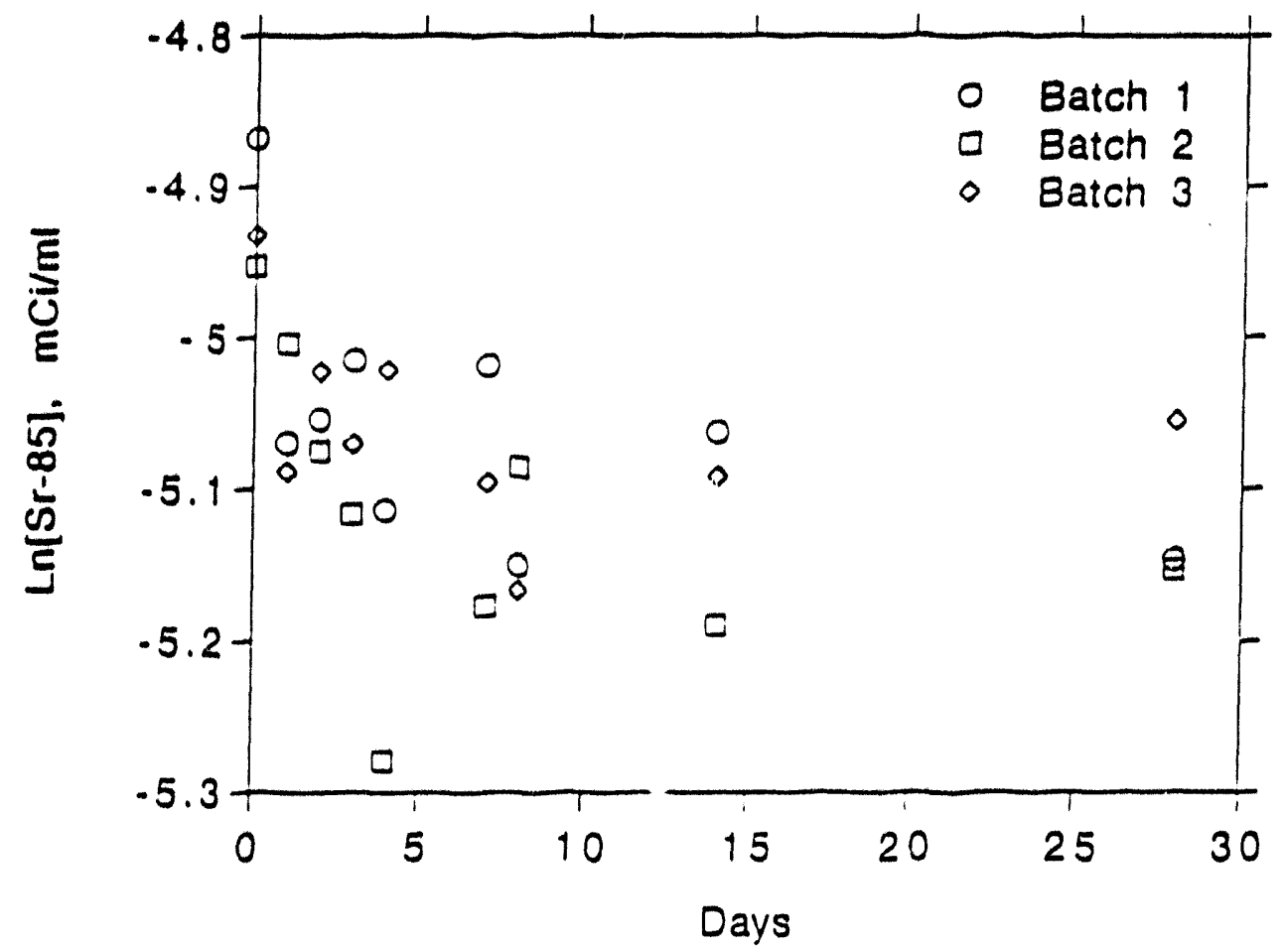

Figure 2. Natural log of the solution concentration of Sr.85 in the adsorption kinetics experiments as a function of time.

\section{lon-Exchange as the Mechanism of Strentium Adsorotion onte Hanford Sediments}

Interpretation of the $K_{f}$ results in terms of an ion-exchange mechanism can be explained as follows. The thermodynamically rigorous mass action equilibrium expression for a birary cation-exchange reaction, such as strontium or cesium adsorbing onto a calcium saturated clay, is

$$
a N^{0}+b(M X) \rightarrow a(N X)+b M a+
$$

where $a=$ valence of macro ion

$$
\begin{aligned}
& N=\text { trace component (e.g., strontium) } \\
& b=\text { valence of trace ion } \\
& M=\text { macro component in binary system (e.g.. calcium) } \\
& X=\text { solid adsorbent ( } 100 . N \text { Area sediment) }
\end{aligned}
$$


The equilibrium constant, $K$, can be expressed as

$$
K=\left([N X]^{a}(M a+]^{b}\right) /\left([M X]^{b}(N b+]^{a}\right)
$$

where brackets, $Q$, indicate thermodynamic activities. If one assumes that the exchange capacity, $C$, of the solid adsorbent is constant (equivalents per unit weight) and that $N$ is preseilt at low (trace) concentration, then the concentration of the trace constituent adsorbed, $(N X)$, is much smaller than $C$, and the concentration of macro ions adsorbed on exchange sites, $(M X)$, is approximately equal to Cia [i.e., $[M X]=C / a]$ in terms of moles per unit of weight, because $C=(N X) b+(M X) b$. Then, by using the standard definition of the distribution coefficient, $K_{d}=(N X) /(N b+)$, where $(N b+)$ is the solution concentration of the trace constituent at equilibrium with the solid, and by substituting the relationship that activity is equal to the concentration umes an activity coefficient, i.e., $[A]=\gamma(A) \cdot(A)$, one can rewrite equation 2 as

$$
K=\left[\left(K_{d}\right) a(M a+) b /(C / a) b\right] \cdot \Gamma
$$

where $\Gamma$ is the ratio of the activity coefficients:

$$
\Gamma=\left[\gamma^{a}(N X) ; 0\{M a+] /\left[\% b\{M X\} \gamma^{a}\{N b+]\right]\right.
$$

For ideal ion exchange of a trace constituent where the exchange capacity, $C$ is constant, the ratio of activity coefficients for the adsorbed ions, $r(N X) / \%(M X)$, is constant. Further, for low ionic strength solutions the ratio $p\left(\mathrm{Ma}^{\mathrm{a}}+\mathrm{j}_{\mathrm{r}} \mathrm{a}(\mathrm{Nb}+\}\right.$ is also constant, and thus $\Gamma$ becomes constant. Using these conditions/assumptions and a loganthmic transform of equation 3 , the dependence of $K_{d}$ (the trace constituent distribution coefficient) on the macro ion concentration, (M), reduces to $-b / a$, the ratio of tracer ion charge to the macro ion charge. For exchange of $\mathrm{Sr}^{2}+$ for $\mathrm{Ca}^{2}+, \mathrm{b} / \mathrm{a}$ is -1.0 .

A linear regression of the data in Figure gives the following equation

$$
\log K_{n}=-0.890 \log [\mathrm{Ca}-\mathrm{Mgl}-1.058
$$

The slope -0.39 is close to the theoretical value of -1.0 , which suggests that ion-exchange is the dominant adsorption mechanism for strontium; however, it is different from -1.0 by an amount which suggests that another mechanism may also be operative.

\section{Column Experiment Results}

In order to verity the validity of the adsorption data discussed in the previous sections of this paper, three column experiments were conducted. Each expenment was run at a flow rate of approximately 5 pore volumes per day. The first two column experiments $\left(\mathrm{H}_{1}\right.$ and $\mathrm{H}_{2}$ ) were conducted using a solution concentration of $0.00312 \mathrm{M} \mathrm{Ca}\left(\mathrm{NO}_{3}\right)_{2}, 0.000823 \mathrm{M} \mathrm{Mg}\left(\mathrm{NO}_{3}\right)_{2}$ and $0.00156 \mathrm{M} \mathrm{Na}_{2} \mathrm{SO}_{4}$. The third column (L3) was conducted using solution concentrations of $0.000624 \mathrm{M} \mathrm{Ca}\left(\mathrm{NO}_{3}\right)_{2}, 0.000165 \mathrm{M} \mathrm{Mg}\left(\mathrm{NO}_{3}\right)_{2}$ and $0.000312 \mathrm{M} \mathrm{Na}_{2} \mathrm{SO}_{4}$. Each experiment was initiated by conducted by pumping approximately one pore volume of Sr-85 spiked influent 
solution. Subsequently, unspiked solution was pumped through the column for the duration of the experiment. The results of these experiments are plotted in Figures 4 to 6 , as C/Co for Sr85 as a function of pore volume of effluent. Also shown on these figures are model fits to the data using two-site/two-region model(Parker and van Genuchten, 1984). In this model the adsorption term is assumed to consist of two components, one governed by equilibrium adsorption and one by first-order kinetic non-equilibrium adsorption. Modeling parameters are listed in Table 3. $A$ is the retardation factor. $D$ is the dispersion coefficient. $\beta$ and $\omega$ are dimensionless variables from which the first-order rate coefficient, $\alpha$, is determined.

In the case of columns $\mathrm{H} 1$ and $\mathrm{H} 2$ the modeling was conducted by fixing the retardation factor to values expected from the equilibrium $K_{d}$ values determined in the batch acsorption experiments. The adsorption rate coefficients determined in this manner for columns $\mathrm{H} 1$ and $\mathrm{H} 2$ are very reproducible and are consistent with the results from the batch kinetic experiments.

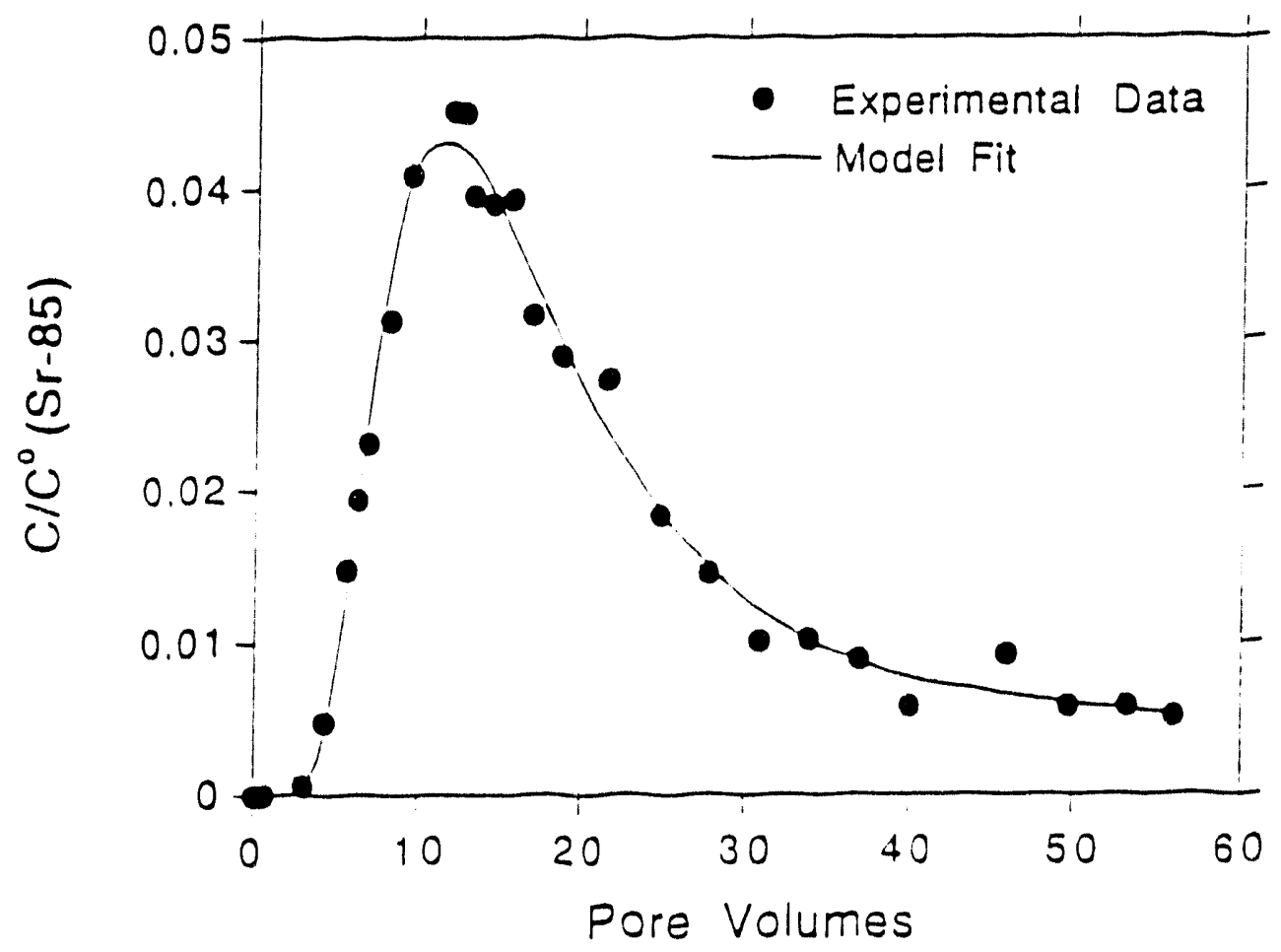

Figure 4. Experimental Sr.35 adsorption/desorption results and model fit for column $\mathrm{H}_{1}$. 


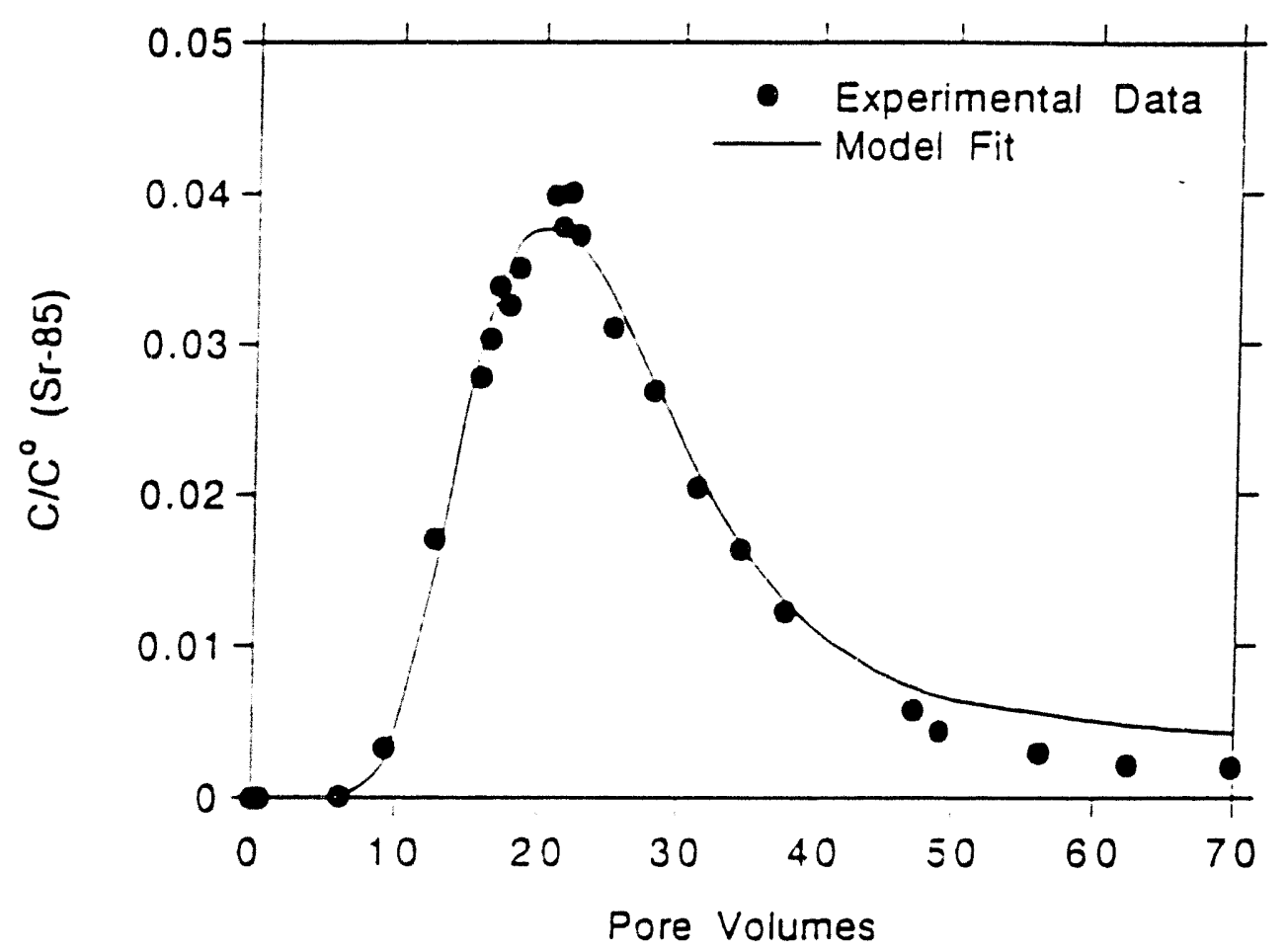

Figure 5. Experimental Sr-35 acsorotion/desordtion results and model fit for column H2.

In the case of column L1, the expected retardation factor was 292. When this value was fixed, the model did not converge to a reasonable fit of the data. When the model was allowed to fit for the retardation factor. the model converged to a reasonable fit but the fitting parameter results were not reasonable. The retardation factor was determined to be 2376 and $\alpha$ was determined to be 0.005 days ${ }^{-1}$ The retardation factor determined by the mocel fit was eight times larger than that expected from our batch adsorption expenments. In acciticn the $\alpha$ determined by the model fit was smailer than that determined by the fits of the $\mathrm{H} 1$ and $\mathrm{H} 2$ column data by a factor of 20 . The reason for the problems in fitting the $L$ i data have not yet been resolved. 


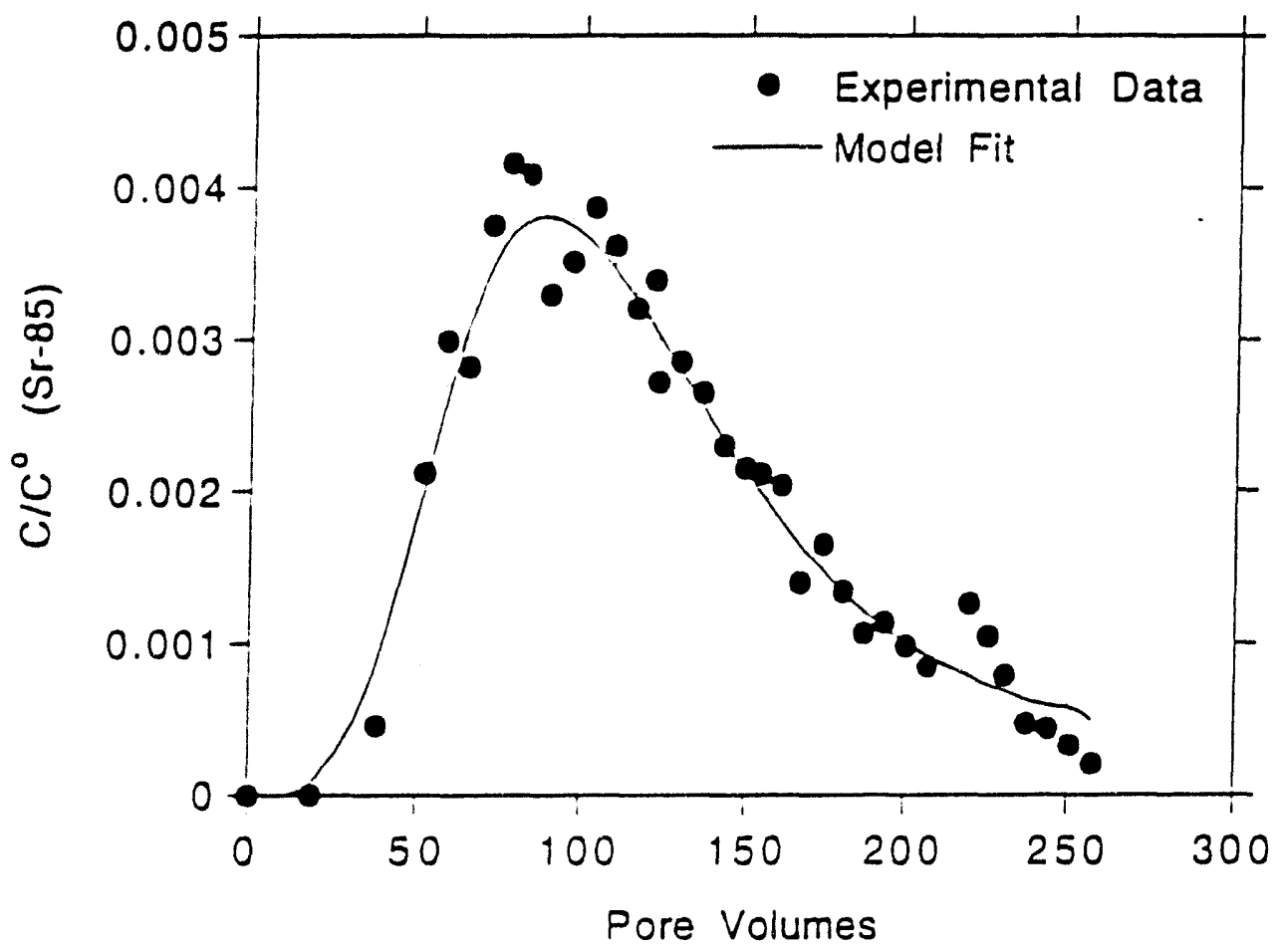

Figure 6. Experimental Sr-85 adsorption/desorption results and model fit for column L1.

Table 3. Modeling parameters determined for column transport experiments.

\begin{tabular}{|c|c|c|c|c|c|}
\hline Column & R & $O\left(\mathrm{~cm}^{2} /\right.$ day $)$ & $\beta$ & $\omega$ & $\alpha\left(\right.$ days $\left.^{-1}\right)$ \\
\hline$H 1$ & 66.4 (held constant) & 27.3 & 0.307 & 0.706 & 0.095 \\
\hline $\mathrm{H} 2$ & 67.0 (held constant) & 10.4 & 0.379 & 0.662 & 0.100 \\
\hline L1 & 2376 & 22.5 & 0.067 & 1.56 & 0.005 \\
\hline
\end{tabular}


WHC-EP-0675

\section{Beferences}

Parker, J. C. and M. Th. van Genuchten. 1984. Determining Transoort Parameters from Laboratory and Field Tracer Experiments. Virginia Agricultural Experiment Station Bulletin 84-3, Virginia Polytechnic Institute and State University, Blacksburg, Virginia. 
WHC-EP-0675

DISTRIBUTION

Number of Copies

\section{OFFSITE}

2

Confederated Tribes of the

Umatilla Reservation

P.0. Box 638

Pendleton, Oregon 97801

J. R. Wilkinson

2

Nez Perce Tribal Office

P.0. Box 305

LaPwai, Idaho 83540

D. Powaukee

1

Southwest Research Institute 6220 Culebra Road

San Antonio, Texas 78284

B. Sagar

2

Yakima Indian Nation

2552 Haines

Richland, Washington 99352

R. F. Cook

\section{ONSITE}

9

U.S. Department of Energy, Richland Operations office

K. V. Clarke

A5-15

B. A. Davis

R3-82

M. J. Furman

R3-81

J. M. Hennig

R3-80

M. P. Johansen

A5- 19

R. N. Krekel

A5-15

J. E. Rasmussen

A5- 15

R. K. Stewart

H. R. Trumble

A5-19

S. H. Wisness

A5-19

RL Public Reading Room

A5-15

A $1-65$

Pacific Northwest Laboratory

PNL Technical Files

$k 1-11$ 


\section{DISTRIBUTION (cont)}

Number of Copies

\section{ONSITE (cont)}

38
Westinghouse Hanford Company

D. J. Alexander (5)

H6-06

L. E. Borneman

W. G. Cox

K. R. Fecht

B. H. Ford

M. J. Hartman

D. G. Horton

G. S. Hunacek

V. G. Johnson (5)

D. E. Kelley

A. J. Knepp

K. A. Lindsey

M. R. Morton

R. E. Peterson

S. P. Reidel

K. M. Singleton

D. R. Speer

D. K. Tyler (3)

S. E. Vukelich

Central Files

Document Processing and Distribution (2)

Environmental Restoration

Program Information Center (5) H6-08 Information Release Administration
$\mathrm{B} 2-35$

H6-23

H6-06

H6-06

H6-06

H6-06

$\times 0-41$

H6-06

R3-46

H6-06

H6-06

R2-77

H6-06

H6-06

H6-06

R1-48

H6-06

$\mathrm{H} 6-02$

L8-04

L8-15

L8-07 

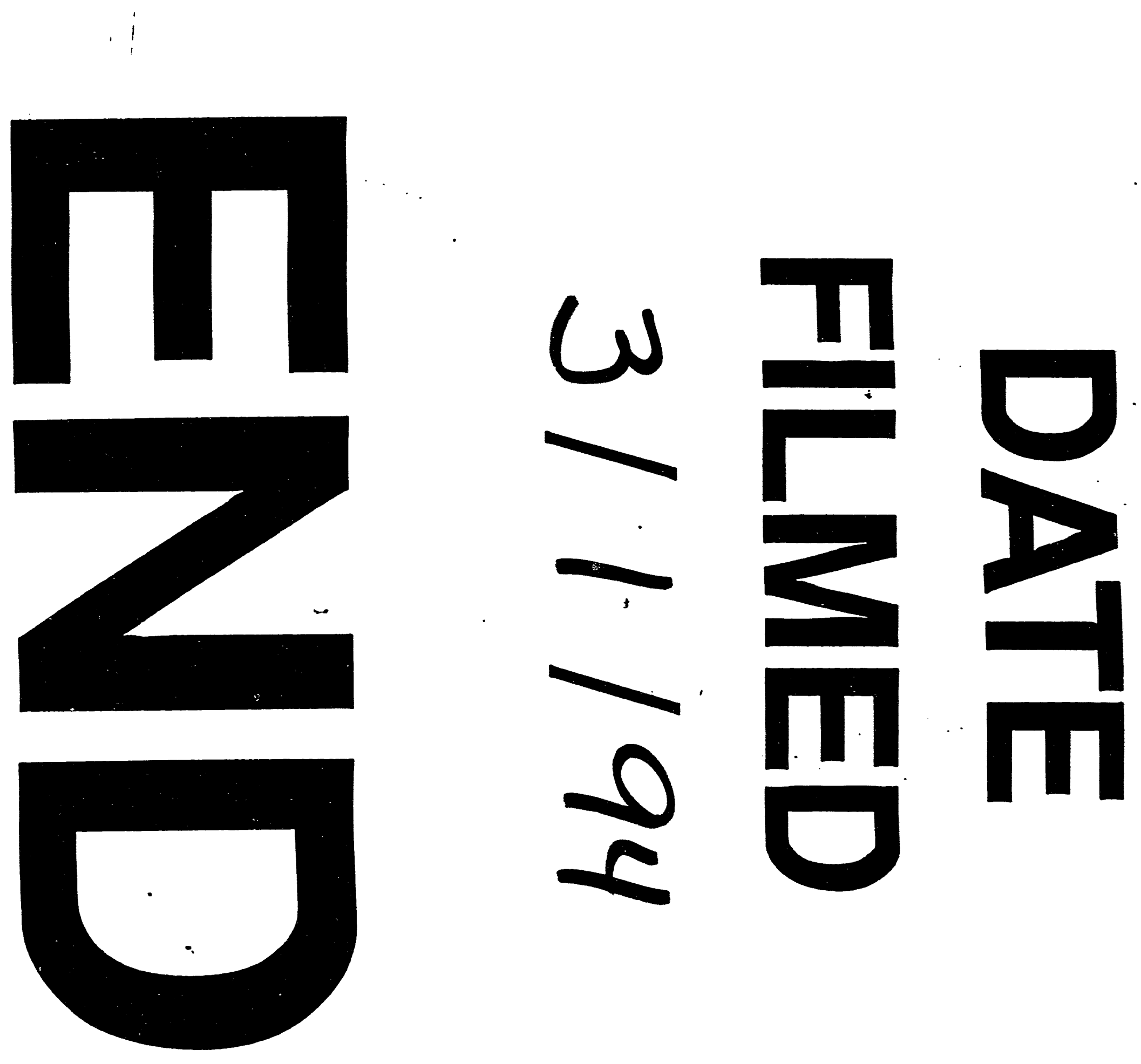
